\section{ENERGY}

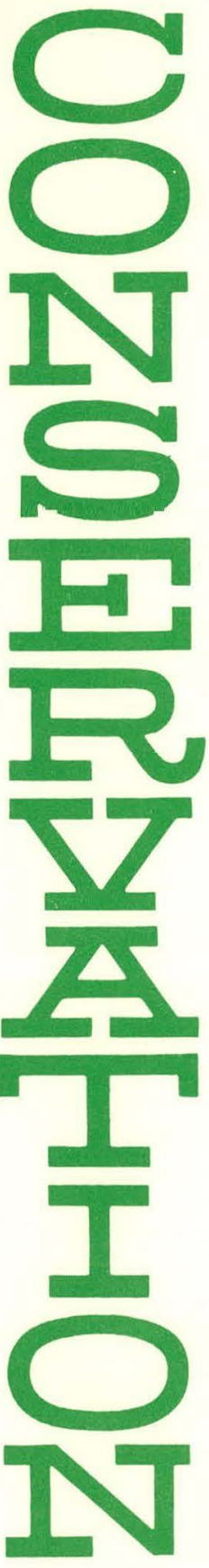

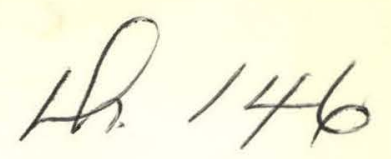

SAN-1171-4

\title{
EFFICIENCY IMPROVEMENTS IN PIPELINE TRANSPORTATION SYSTEMS
}

Technical Report, Task 3

By

William F. Banks

James H. Horton

Work Performed Under Contract No. EY-76-C-03-1171

U. S. Department of Energy

San Francisco Operations Office

Oakland, California

\section{U. S. DEPARTMENT OF ENERGY}

Division of Transportation Energy Conservation 


\section{DISCLAIMER}

This report was prepared as an account of work sponsored by an agency of the United States Government. Neither the United States Government nor any agency Thereof, nor any of their employees, makes any warranty, express or implied, or assumes any legal liability or responsibility for the accuracy, completeness, or usefulness of any information, apparatus, product, or process disclosed, or represents that its use would not infringe privately owned rights. Reference herein to any specific commercial product, process, or service by trade name, trademark, manufacturer, or otherwise does not necessarily constitute or imply its endorsement, recommendation, or favoring by the United States Government or any agency thereof. The views and opinions of authors expressed herein do not necessarily state or reflect those of the United States Government or any agency thereof. 


\section{DISCLAIMER}

Portions of this document may be illegible in electronic image products. Images are produced from the best available original document. 


\section{NOTICE}

This report was prepared as an account of work sponsored by the United States Government. Neither the United States nor the United States Department of Energy, nor any of their employees, nor any of their contractors, subcontractors, or their employees, makes any warranty, express or implied, or assumes any legal liability or responsibility for the accuracy, completeness or usefulness of any information, apparatus, product or process disclosed, or represents that its use would not infringe privately owned rights.

This report has been reproduced directly from the best available copy.

Available from the National Technical Information Service, U. S. Department of Commerce, Springfield, Virginia 22161.

Price: Paper Copy $\$ 10.75$

Microfiche $\$ 3.00$ 


\title{
EFFICIENCY IMPROVEMENTS
}

IN

PIPELINE TRANSPORTATION SYSTEMS

\author{
by \\ William F. Banks \\ James H. Horton \\ 1977 \\ Technical Report - Task 3
Contract EU-76-C-03-1171 \\ SAN FRANCISCO OPERATIONS OFFICE \\ 1333 BROADWAY \\ OAKLAND, CA 94612
}

This report was prepared as an account of work sponsored by the United States Government. Neither the United States nor the United States Department of Energy, nor any of their employees, nor any of their contractors, subcontractors, or their employees, makes any warranty; express or implied, or assumes any legal liability or responsibility for the accuracy, completeness ot use futness of any information, apparatus, product or process disclosed, or represents that its use would not infringe privately owned rights.
ints

$\checkmark$ ENERGY RESEARCH AND DEVELOPMENT ADMINISTRATION 
FOREWARD

ABSTRACT

PREFACF

GLOSSARY

FIGURES

TABLES

1.0 OBJECTIVES

1.1 Purpose of the Project

1.2 Purpose of this Project

2.0 SUMMARY

2.1 Recommended Programs

2.2 Candidate Improvements

3.0 RECOMMENDED R, D, \&D PROGRAMS

4.0 POWER CONVERSION IMPROVEMENTS

4.1 Heat Engine Improvements

1.1.1 Brayton Fingine Tmprovements

4.1.1.1 Regenerative Cycles

4.1.1.2 Brayton-Rank inc Combined Cycles

4.1.1.3 Comparison of cias Turbine cycles

4.1.1.4 Combined System Performance

4.1.2 Diesel Engine Improvements

4.1.2.1 Diese1-Brayton Comblned Cycles

4.1.2.2 Diesel-Rankine Combined Cycles

4.1.3 Otto Engine Improvements

4.2. Electric Motor Improvements

4.2.1 Improvements in Motor Efficiency

4.2.2 Improvements in Speed Variability

4.3 Fuel Cells

4.3.1 Fuel Cell Description

4.3.2. Attractive Characteristics of Fuel Cells

4.3.3 Problem Areas

$4,3,4$ Fuel Cell Development Status

4.3.5 Technology Assessment

4.3.5.1 Fuel processing Technoluyy

4.3.5.2 Fuel Cell Technology

4.3.5.3 Power Conditioning Tcohnology

4.3.6 Pipeline Applications of Fuel Cells

4.3.6.1. Duty Cycles in Products Pipelines

4.3.6.2 Fuel Cells with DC Motors

5.0 SLURRY SYSTEM IMPROVEMENTS

5.1 Technological Status of Coal slurry Pipelines

5.2 Methano1-Coal Slurries 
5.2.1 Methanol Carrying Capacity

5.2.1.1 Experimental Measurements of Carrying Capacity

5.2.1.2 Importance of Carrying Capacity

5.2.1.3 Benefits of Dry Coal.

5.2.2 Methanol Consumption and Marketing Options

5.2.3 Problem Areas

5.2 .3 .1 Safety

5.3.3.2 Environmental. Impact

5.3 Slurry-fired Engines

5.3.1 Reciprocating Engines

5.3 .2 . Gas Turbines

5.3 .3 Boilers

6.0 SUBSTITUTION OF COAL FOR PETROLEUM AND GAS IN PIPELINE OPERATIONS

6.1 Coal Dust as a Pipeline Driver Fuel

6.1.1 Coal Dust as an Engine Fuel

6.1.1.1 Reciprocating Engine Fuel

6.1.1.2 Gas Turbine Fuel

6.1.2 Logistics of Coal Consumption in Pipelines

6.2 Logistics of Methanol-Coal Slurry as Pipeline Fuel

7.0 FLOW INDUCER IMPROVEMENTS

7.1 Liquid Pumps

7.1.1 Centrifugal Pumps

7.1.2 Positive Displacement Pumps

7.2 Slurry Pumps

7-3 Compressors

8.0 REDUCTION OF RESISTANCE TO FLUID FLOW

8.1 Pipeline Heating to Reduce Viscosity

8.2 Internal Coatings to Reduce Viscosity

8.3 Additives to Reduce Viscosity

9.0 OTHER IMPROVEMENTS

9-1 Cybernetics of Pipeline systems

9-2 Leakage Inhibitors

9.2.1 Leakage in Liquid Pipelines

9.2.2 Leakage in Gas Pipelines

10.0 RFFERENCES 


\section{Abstract}

The primary purposes of this report are the identification of those potential energy-conservative pipeline innovations which are most energy-effective and cost-effective, and the formulation of recommendations for the $R, D$, and $D$ programs needed to exploit those opportunities. From a candidate field of over twenty classes of efficiency improvements, eight systems are recommended for pursuit. Most of these possess two highly important attributes : large potential energy savings and broad applicability outside the pipeline industry. The $R$, D, and D program for each improvement and the recommended immediate next step are described. 


\section{PREFACE}

Subsequent to Congressional approval of the Department of Energy Organization Act of 1977 (Public Law 95-91 - Aug. 4, 1977), various federal government departments and agencies previously having some form of regulatory jurisidiction over pipelines were removed of some or all of their regulatory responsibilities. These regulatory responsibilities were transferred, mainly, to either the Federal Energy Regulatory Commission (FERC) or the Economic Regulatory Administration (ERA) within the newly formed Department of Energy ( $D O E$ ).

Two of the independent agencies, the Federal Power Commission (FPC) and the Federal Energy Administration (FEA), were liquidated and all of their duties transferred to the DOE. In addition, the Interstate Commerce Commission (ICC), as related to its pipeline regulatory responsibilities, was relieved of all of its duties except for jurisdiction over coal slurry pipelines. The remaining federal agencies and departments described in section 5.0 of report number HCP/M-1171-3 of this series (i.e. the Department of Transportation, the Environmental Protection Agency, the Department of the Interior and the Department of Labor) retained their regulatory responsibilities over pipelines.

FERC (an independent, five-member organization with the DOE) inherited most of the gas pipeline regulatory functions of the FPC. In addition, FERC inherited the authority of the ICC to establish rates or charges for the transportation of oil by pipelines as well as the valuation of such pipelines. Under the DOE Organization Act, the FERC was delegated the following general responsibilities:

- Issue and enforce licenses for hydroelectric power-projects.

- Establish and enforce rates and charges for the sales and transmission of electricity and for the non-emergency interconiection of facilities for the generation, transmission, and sale of electricity.

- Establish and enforce rates and charges for the transmission and sale of natural gas. 
- Issue and enforce certificates of public convenience and necessity for construction of facilities, abandonment of services or facilities, etc., for natural gas pipelines.

- Establish and enforce curtailments of natural gas (other than establishment and review of curtailment priorities).

- Regulate mergers and securities acquisitions under the Natural Gas Act and Federal Power Act.

- Other functions as may be assigned by the Secretary

The ERA is charged with administering many of the DOE's regulatory programs other than those of the FERC. The ERA inherited the former responsibilities of the FEA as related to oil pricing, allocation, and import programs. In addition, the ERA administers other regulatory programs, including conversion of oil- and gasfired utility and industrial facilities to coal; natural gas 1mport/ export controls; natural gas curtailment priorities and emergency allocations; regional coordination of electric power system planning and reliability of bulk power supply, and emergency and contingency planning.

Under the DOE Organization Act, the ERA was delegated the following responsibilities:

- Assure availability and regulate pricing and allocation of crude oil, natural gas liquids, and natural gas liquids products.

- Assure availability and regulate pricing and allocation of petroleum.products

- Develop and implement standby and emergency regulations and programs.

- Assure compliance with and enforcement of ERA program regulations.

- Ensure market competition.

- Provide a Special Counsel for compliance and enforcement.

- Administer program f'or conversion of utilities and MFBI's to coal.

- Intervene before FERC and other Federal regulatory agencies (with Assistant Secretaries and General Counsel) 
- Perform compliance and litigation for regulatory programs (with Assistant Secretaries and General Counsel).

- Intervene before state utility regulatory proceedings (with Assistant Secretaries and General Counsel).

- Regulate natural gas and electric power imports and exports.

- Establish natural gas curtailment priorities.

- Assure voluntary coordination of electric utilities.

- Perform long range utility planning.

- Assure establishment of emergency interconnections.

- Review interlocking directorates.

- Perform non-FERC oil pipeline regulation.

Pipeline industry data collection, previously done by the BOM, FPC, and ICC has been consolidated under the Energy Information Administration of the DOE. This organization is responsible for the collection of data required by the FERC and the ERA.

It is of particuiar interest to note that the FERC, as stated in the DOE Organization Act, is not subject to the supervision or direction of any other official of the DOE. However, the ERA is charged with the responsibility of organizing and managing an active intervention program on behalf of the Secretary of the DOE before the FERC and other Federal and State regulatory agencies in support of Departmental policy objectives.

It is apparent then that the FERC is now the principle pipeline regulatory agency of the Federal Government. It concerns itself with tariffs, profits and other similar matters that directly impact the day to day operation of a pipeline. The reporting requirements previously administered by the FPC and ICC are now handled by the FERC. The duties of the ERA are more broad and policy oriented than FERC. It is apparent from the list of their responsibilities that the ERA is interested in assuring that energy is distributed and allocated fairly and at reasonable prices. The ERA does not involve itself with daily operation unless it becomes necessary to influence the industry to achieve a policy objective, or change a condition such as a market place imbalance. 
This study was substantially completed before the DOE was created. As a.result, references to the pipeline regulatory structure do not acknowledge the events and agencies described above. The purpose of this preface is to alert the reader to this situation and to update the regulatory references of this report. In general, an accurate understanding of the regulatory structure of the Federal Government as relates to pipelines will result if the reader substitutes DOE (FERC) for all references to the FPC or ICC in the context of gas and oil pipeline regulation. 


\section{GLOSSARY OF ABBREVIATIONS, SYMBOLS AND TERMS}

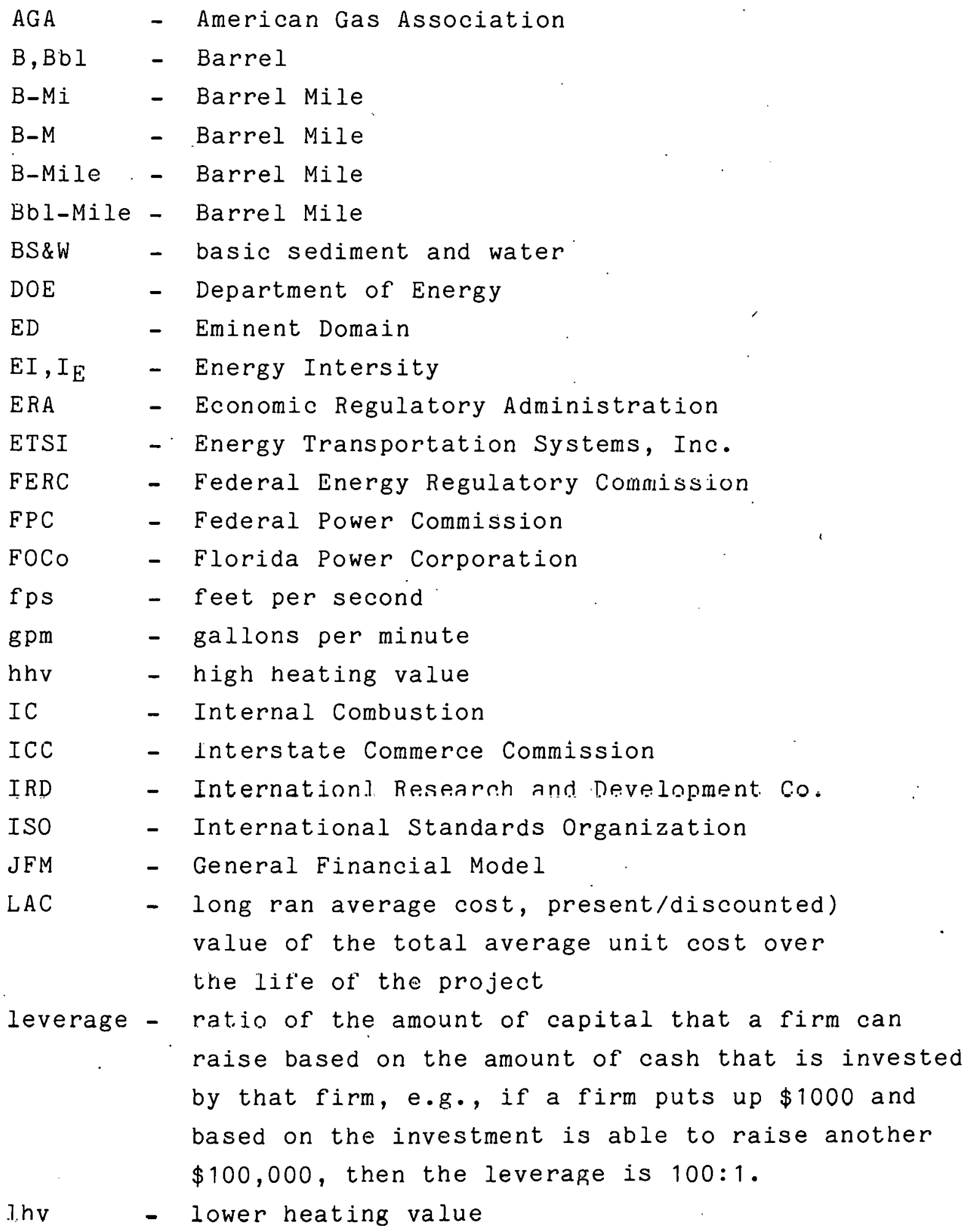




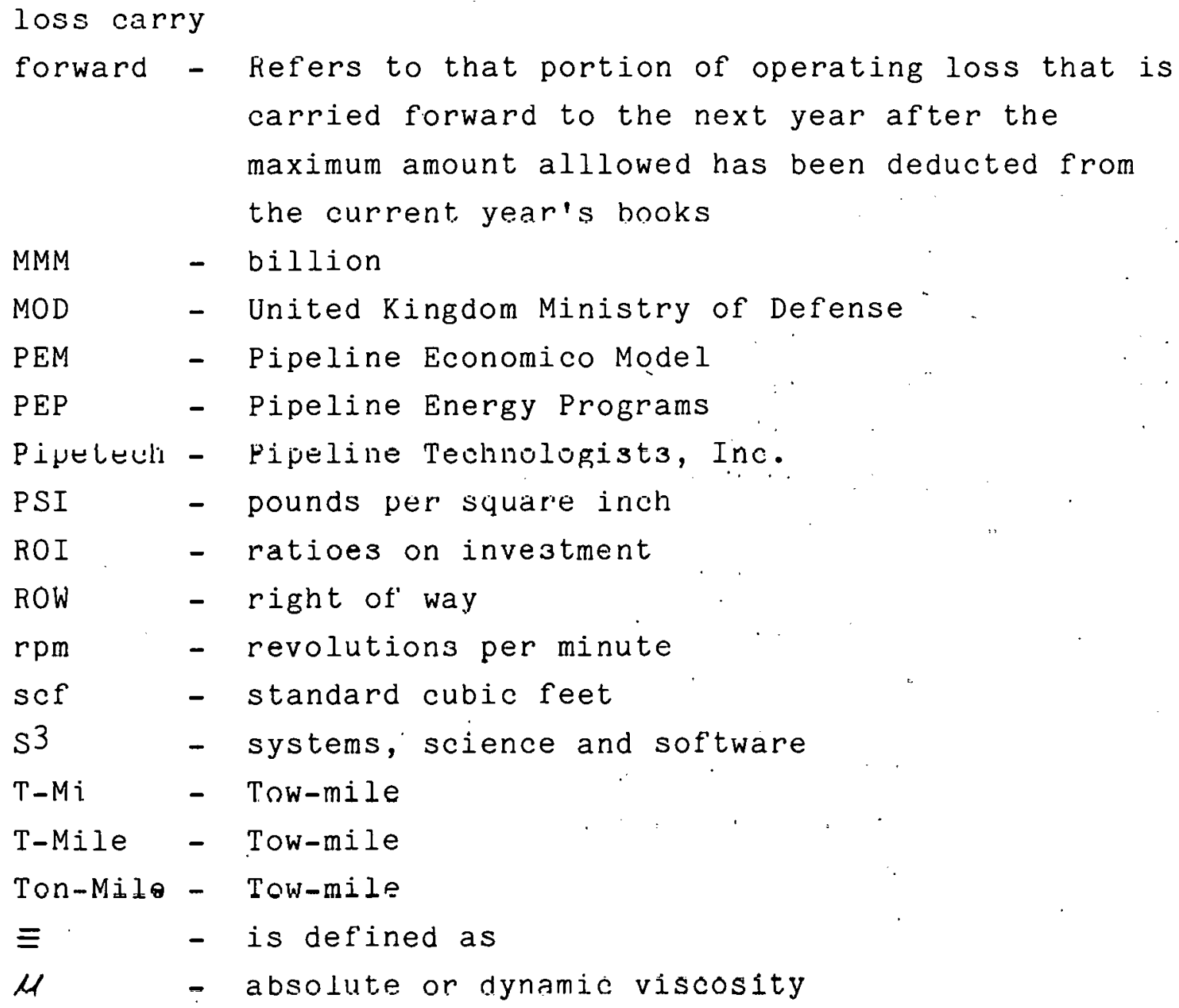




\section{FIGURES}

\begin{tabular}{|c|c|c|}
\hline & & age \\
\hline $.0-1$ & Generic Phase 2 schedule & $3-4$ \\
\hline$\cdot 1 \cdot 1-1$ & Typical centrifugal compressor characteristics & $4-3$ \\
\hline $1 \cdot 1-2$ & $\begin{array}{l}\text { Gas turbine performance match with pipeline } \\
\text { requirements }\end{array}$ & $4-4$ \\
\hline $.1 \cdot 1 \cdot 1-1$ & Two-staft regenerative cycle gas turbine & $4-6$ \\
\hline . 1 . & $\begin{array}{l}\text { Effect of pressure ratio in regenerative } \\
\text { Brayton cycles }\end{array}$ & $4-8$ \\
\hline$\cdot 1 \cdot 1 \cdot 1-3$ & Effects of regenerator effectiveness & $4-9$ \\
\hline$\cdot 1 \cdot 1 \cdot 2-1$ & $\begin{array}{l}\text { Simple cycle gas turbine/Rankine cycle combined } \\
\text { power plant }\end{array}$ & $4-1$ \\
\hline$\cdot 1 \cdot 1 \cdot 2-2$ & Efficiencies of regenerative and combined cycles & $4-1$ \\
\hline$\cdot 1 \cdot 1 \cdot 3-1$ & $\begin{array}{l}\text { Increase in specific fuel consumption at part } \\
\text { load, typical two-shaft gas turbines }\end{array}$ & $4-1$ \\
\hline $1 \cdot 1 \cdot 3-2$ & Typical output, gas dynamics submodel & $4-1$ \\
\hline $\begin{array}{l}\cdot 1 \cdot 3-3 \\
: \\
.1 \cdot 3-4\end{array}$ & $\begin{array}{l}\text { Natural gas reference system, baseline case } \\
\text { Gas reference system conversion to combined cycle }\end{array}$ & $4-24$ \\
\hline $1 \cdot 1 \cdot 4-1$ & Combined system efficiency with gas turbine & $4-3$ \\
\hline $1.2 \cdot 1-1$ & $\begin{array}{l}\text { Napier nomad turbocompound diesel engine - } \\
\text { schematic arrangement }\end{array}$ & $4-3$ \\
\hline-2 & Johnston engine sch & $4-4$ \\
\hline-3 & Johnston engine performance & $4-4$ \\
\hline $1-4$ & Johnston engine piston cyclinder configuration & $4-4$ \\
\hline-1 & Carnot-equivalent cycle- & $4-4$ \\
\hline-2 & Saturation 1 ine for water & $4-4$ \\
\hline-3 & al satur & -2 \\
\hline
\end{tabular}


FIGURES

$\underline{\text { Paye }}$

4.1.2.2-4 Diesel-organic Rankine-cycle compound engine 4-51 flow schematic

4.1.3-1 Combined-cycle efficiency with gas reciprocators 4-56

4.1.3-2 Typical heat balance, 4-stroke, naturally 4-57 aspirateã gas engine

4.3.1-1 Fuel cell concept 4-64

4.3.1-2 The fuel cell power plant 4-65

4.3.2-1 Fuel economy/efficiency for all sizes 4-66

4.3.2-2 Fuel economy/efficiency at part load 4-67

4.3.2-3 Environmental impact 4-68

4.3.2-4 Waste heat recovery. potential 4-69

4.3.6.1.1-1 Pump and system characteristics. 4-81

4.3.6.1.2-1 Hydraulic gradient, one pump, all gasoline 4-90

-2 " , two pumps, " " 4-91

-3 " " three "," " 4-92

$-4 \quad$ " , four ", " " 4-93

-5 " " " five ", " " 4-94

-6 " " six ", " " " " 4-95

-7 " " seven ", " " 4-96

-8 " " eight/nine " " 4-97

-9 " " , seven/eight pumps, one 4-98

ségment tuel oil, thite segments gasoline

-10 " " seven pumps, two segments 4-99 fuel oil, two segments gasoline

-11 " " seven/eight pumps, three 4-100 segments fuel oil, one segment gasoline 


\section{FIGURES}

$\underline{\text { Page }}$

-12 Hydraulic gradient, eight pumps, all fuel oil 4-10l

-13 " , eight pumps, one segment 4-102 propane, three segments gasoline

-14 " ", eight pumps, two initial 4-103 segments propane, two segments gasoline

-15. " " seven pumps, two initial 4-104 segments propane, two segments gasoline

-16" " , eight/nine pumps, two init- 4-105 ial segments gasoline, two segment propane

-17 " , eight/nine pumps, three 4-106 initial segments gasoline, last segment propane

-18 " " , eight/nine pumps, all propane 4-107

-19 Power cost vs. throughput 4-108

-20 Unit energy cost and total throughput 4-109

-21 Throttling energy wasted in typical full capa- 4-110 city products pipeline duty cycle

5.1.1 Map of Black Mesa coal slurry pipeline 5-2

5.1-2 Photographs of components of Black Mesa 5-3 pipeline system

5.1-3 Photographs of Black Mesa coal preparation plant 5-5 system

$5.2 .1 .1=1$ Rheological Model $5-13-$ through 22

5.3.2.1 NO emissions - gas turbine test with methanol 5-52

5.3.2.2 Co emissions - gas turbine test with methanol fuel 5-52

6.1.1.2-1 All previously installed closed-cycle industrial/ 6-10 utility power plants

7.1.1-1 Typical characteristic curves at constant rpm 7-2 


\section{FIGURES}

$\underline{\text { Page }}$

7.1.1-2 Efficiency of single-stage pumps 7-3

7.1.1-3 Efficiency curves for small commercial pipeline 7-4 pump

7.1.1-4 Head capacity curves of pumps operating in parellel 7-6

7.1.1-5 Head capacity curves of pumps operating in series 7-7

7.1.1-6 Head capacity curves at design speed and reduced 7-9 speed - two pumps in series

7.1.2-1 Capacity and horesepower characteristics of a 7-10 typical rotary pump

7.2-1 Piston pump - fluid enã 7-14

7.2-2 Plunger pump - fluid end 7-15

7.3-1 Transmission line compression installed 7-23

7.3-2 Centrifuqal compressor case characteristics 7-25

7.3-3 Solar C505 compressor performance 7-27.

7.3-4 Horsepower required for centrifugal and recipro-. 7-29 cating compressors

8.1-1 Basic skin effect tracing circuit 8-4

8.1-2 Details of SECT power circuit $8-4$

8.1-3 Approximate temperature variation of liquid 8-6 viscosity

8.2-1 Performance on original tests, Nov. and Dec. 1958 8-12

8.2-2 Performance of the same pipe one year after the 8-12 tests described in Fig. $8.2-1$

8.3-1 Schematic of the mean velocity profile during 8-18 drag reduction according to classic sublayer model

9.1-1 On-line computer control 9-5 


\section{FIGURES, P. 4}

Page

9.1-2 Remote computer control of unattended pump stations 9-7

9.1-3 Closed loop computer control of pipeline system 9-9

9.1-4 ARCO Western Oklahoma crude condensate line block- 9-10 clear computer control program

9.1-5 Minicomputer in-station control at tankage .. 9-11 locations 


\section{LIST OF TABLES}

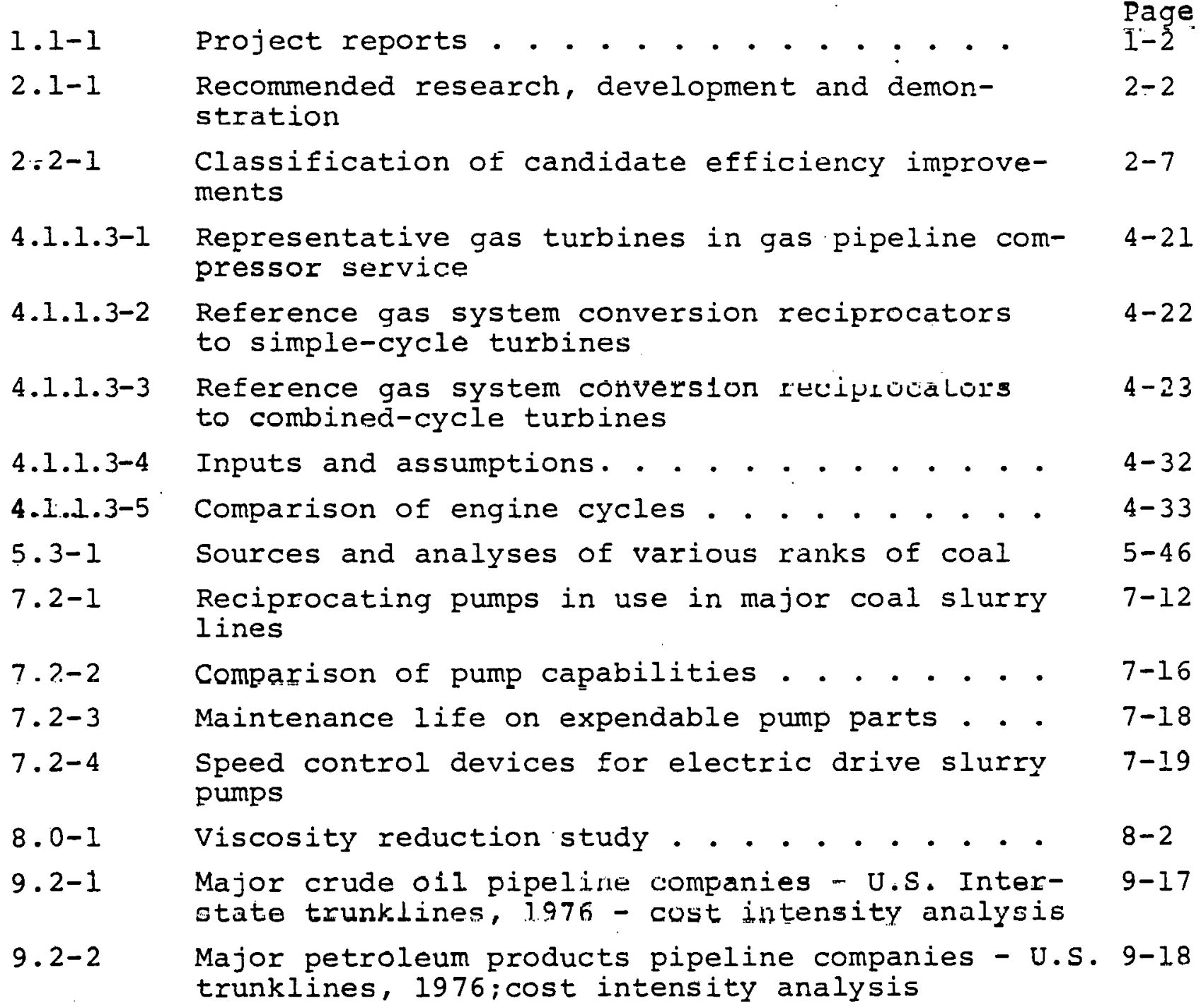




\section{$1: 0$ OBJECTIVES}

7.1 Purpose of the Project

The work reported here is a part of a project which was

conducted by the team of systems, science and software $\left(\mathrm{S}^{3}\right)$ of San Diego, and Pipe Line Technologists, Inc. (Pipetech) of Houston, under DOE contract EY-76-C-03-1171, "Energy Study of Pipeline Transportation Systems." The basic purpose of the project was to assess the susceptibility of the oil, gas, and other pipeline industries to energy-conservative technological innovations, and to identify the necessary research, development, and demonstrations $(R, D, \& D)$ to exploit those opportunities.

The project final report was published as DOE report HCP/M-1171-1, "An Energy Study of Pipeline Transportation Systems." That final report is an executive summary, combining the results from the reports listed in Table 1.1-l. As will be noted from the table, this present report is one of those task reports.

\subsection{Purpose of this Report}

This report presents the results of Task 3, which has two primary objectives:

(1) Identification of those potential energy-conservative innovations which are most energy-effective and cost-effective.

(2) Formulation of recommendations for the $R, D$, and $D$ programs which are needed to exploit those opportunities: 
TABLE $1.1-1$

Project Reports

$\underline{\mathrm{H} C \mathrm{P} / \mathrm{M}-1171-}$

1

2

$-3$

4

5
Title

An Energy Study of Pipeline Transportation Systems

Energy Consumption in the Pipeline. Industry

Federal. Regulation of the Pipeline Industry

Efficiency. Improvements in Pipeline Transportation Syctems

Energy Conservation Opportunities in the Pipeline .Industry
Associated

Task

Al1

1

2

3

4,5
$\underline{\mathrm{SSS}-\mathrm{R}-77}$

3021

3023

3069

\section{Related Reports}

An Economic. Model of Pipeline Transportation System (Limited Issue)

Slurry Pipelines - Economic and Political Issijes - A kevlew (Limited Issue)

$\mathrm{S}^{3}$ Financial Projection Model - Preliminary User's Manual: and system overview 


\subsection{SUMMARY}

Most of the energy conservation opportunities which are identified here possess two highly important attributes :

(1) The potential energy savings are large, that is, of the order of several hundredths of a quad.

(2) The technology whereby the energy savings may be realized is broadly applicable outside the pipeline industry. An example of attribute (I). will be found in section 4.1 below, where it is seen that bottoming engines and internal cooling of IC engines may each easily aspire, through ultimate industry-wide application, to savings well over a tenth of a quad.

An example of attribute (2) will be found in section 4.3, where the somewhat startling, though still tentative, conclusion is derived that the pipeline application is likely to be a much more attractive breeding ground for fuel cell development than the one upon which virtually all of the money is currently being spent, that is, the electric utility application. Rather than a commentary upon misdirection of $R \& D$, this observation merely reflects the fact that, for various reasons, the utility industry and its equipment suppliers have been energetic in persuading the government to support their $R \& D$, while the pipeline industry has chosen to go its own way. It is, of course, the identification of just such opportunities as this which is the basic purpose of the present study.

\subsection{Recommended Programs}

Table 2.1-1 presents the eight programs recommended for pursuit. This study has concluded that each of the listed programs satisfies the first three of the criteria listed below:

1 - Energy-effective

2 - Cost-effective.

3 - Technically feasible on a moderate (3-7 year) time scale

4 - Broadly applicable outside the pipeline industry. 
Table $2.1-1$

RECOMMENDED RESEARCH, DEVELOPMENT AND DEMONSTRATION

\section{Program}

1. Gas-fired Combined Cycle Compressor Station

2. Internally Cooled Internal Combustion Engine

3. Methanol-Coal Slurry Pipeline

4. Methanol-Coal Slurry-Fired and Coal-Fired F.ngi ines

5. Indirect-Fired Coal Burning Combined Cycle Pump station

6. Fuel Cell Pump station

7. Internal Coatings in Pipelines

8. Drag-Reaucing Additives in Liquid Pipelines
Report Section No.

4.1.1. 4

4.1 .2 .2

5.2 .2

6.1 .1 .2

6.1 .1 .2

4.3 .6 .2

8.2

8.3 
of the eight recommended programs, the first six on Table 2.1-1. additionally satisfy criterion 4 , that is, only programs 7 and 8 are pipeline-peculiar.

For the benefit of the reader who does not require a full, detailed explanation, the recommended programs are succintly summarized below.

It is recommended that the programs discussed below be undertaken. In each case, the program should be coordinated with other active and planned DOE programs and with other government agencies previously and/or currently engaged. in similar or related programs.

(1) Gas-Fired Combined-Cycle Compressor Station

A study and demonstration of a Brayton-Rankine and/or otto-Rankine combined cycle power plant should be conducted using advanced second or third generation gas turbines with organic Rankine bottoming cycle. The program, including selection of engine type, and size should be primarily oriented to pipeline applications but with broad application potential to utilities and other industrial work.

\section{(2) Internal Cooled Internal Combustion Engine}

A study and demonstration of an internally cooled reciprocation internal combustion engine, with bottoming cycle, should be conducted. The objective should be to develop the necessary technology to retrofit existing reciprocating pipeline drivers, and at the same time lay the groundwork for development and application of internally-cooled internal combustion engines for a broad spectrum of non-pipeline applications. 


\section{(3) Methanol-Coal Slurry pipeline}

A study and demonstration of methanol-coal slurry pipeline should be conducted. Their potential for delivering coal over long-distance pipelines at relatively low cost, with low net water requirements, and with a broad spectrum of end use options is extremely attractive.. Conversion of existing pipelines to coal-oil slurry transport may offer a convenient transition to the coalmethanol mode, and a brief comparison of the two systems should therefore be made.

\section{(4). Methanol-Coal-Slurry-Fired and Coal-Fired Engines}

A study and experimental work should be conducted to assess the potential for operating gas turbines on methanol-coal slurry and on pulverized coal separated. from slurry. The program should supplement previous investigations of hot corrosion and erosion problems in turbines and should include work to identify the fouling mechanism, means of 1 hhiblelng fouling, and appivalles fui minimizing the effect of ash deposits on erosion of turbine hot-end components. The work should be closely coordinated and compatiblè: with the study recommended in 2.1(3) above relating to methanolcoal slurry pipelines. :

\section{(5) Fuel Cell Pump Station}

A study and demonstration. should be conducted of high efficiency, indirect-fired gas turbines with Rankine bottoming cycle, using pulverized coal fuel. The program should capitalize on existing technology in closed Brayton cycle engines which have operated successfully on coal in. Europe, but at relatively low efficiency because of limited cycle temperatures. Effort should be concentrated on achieving substantial increases in efficlency through the use of advanced, high-temperature materials in the air heater and the addition of an organic Rankine bottoming system. 
(6) Indirect-Fired Coal-Burning Combined Cycle Pump Station

A study and demonstration should be conducted of fuel cell power sources in combination with DC motors in a liquid pipeline pump station. The pipeline application offers a unique and extremely attrative application for fuel cell power plants for two reasons. First, the use of DC motors in the pipeline application would avoid the need for inverters to convert the fuel cell output to AC. Freed of this burden, the economics of the pipeline application for fuel cells becomes much more attrative than the electricity utility application. Second, the nature of petroleum products pipeline operation is such that the use of DC motors would enable an energy saving in the order of 5-10\%. The fuel cell, of course, offers the opportunity to realize that improvement. The combination of. these two factors indicates that the pipeline is the preferred application for early commercialization of the fuel cell. Accordingly, it is recommenaed that continuing ERDA fuel cell programs be reconsidered in this light.

\section{(7). Drag-reducing Additives in Liquid Pipelines}

Further research should be conducted on drag-reducing additives for liquid pipelines, including: basic research into: the mechanism of drag reduction; system studies to identify operating problems and assess economic aspects; and a demonstration to prove the soundness of the concept in practical pipeline operation.

\section{(8) Internal Coatings in Pipelines}

Demonstrations should be conducted of internal coatings in both gas and liquid pipelines to determine quantitatively their effect on improving pipeline flow efficiencies and to assess the economic potential of their further use in liquid pipelines. The program should begin with analysis and testing to establish the longevity and dependability of present commercial coatings which are applied in place, followed by research and development if necessary, and a demonstration in full station-to-station section of an operating pipeline. 


\subsection{Candidate Improvements}

Early in the study the categories of efficiency improvements listed in Table 2.2-1 were identified as candidates for examination. With few exceptions the numbered improvements represent classes of devices rather than a single device. Thus, even though an improvement category may not appear in the earlier list of recommended programs, it may well be that future inventions will justify a program in that category. For example, this study was unable to identify an electric motor improvement which would be appropriate for DOE support for pipeline application. However, the possibility always exists that a new idea and/or fresh approach, e.g., the . Wanless motor, may appear and offer an opportunity for energy savings.

Additionally, it is well to note that some of the improvements in Table 2.2-1, for example, capsule pipelines, were excluded from Table 2.1-1 on the basis of very preliminary analyses. This exclusion could safely be made at this time because, even if that preliminary conclusion is reversed after further study, the realization of the improvement is still well into the future. Accordingly, it is strongly recommended that the list and the associated conclusions be maintained by recurrent review and update, so that future opportunities can be exploited as they appear. 
TABLE 2.2-I

Classification of candidate efficiency improvements

Heat Engine Improvements

1 - Bottoming engines

2 - Gas turbine regenerators

3 - Internal cooling of internal combustion engines

4 - Slurry-fired engines

5 - Coal-fired engines

6 - Indirect-fired, coal-burning engines

Non-Heat Engine Energy Conversion

7 - Fuel cells

8 - Electric motor improvements

Flow-Inducer Improvements

9 - Pump improvements

10 - Compressor improvenieiits

Slurry Pipelines

11 - Coal-water system improvements

12 - Coal-methanol systems

13 - Cryogenic systems

14 - Pneumatic slurries

Draig Reduction

15 - Heating

16 - Additives

17 - Internal coatings

Leak Prevention

18 - Internal coatings

Operational Improvements

19 - Automatic control of transients

20 - Computerized optimization of duty cycles

21 - Improved capital utilization

None of the Above

22 - Capsule pipelines 
3.0 RECOMMENDED $R, D$, \& D PROGRAMS

This section presents the broad outlines of the prograns of research, development, and demonstration which are needed to realize the energy-conservative potential of the technological innovations that are discussed in later sections of this report.

In each case the recommended program consists of the six phases which are described below:

Phase 1 - Identification of the opportunity

This phase has been in progress under the present study, and with the publication of this report is now complete.

Phase 2 - Concept Valiaation

In this phase the concept is validated analytically and a definitive program plan is develuped.

Phase 3 - Research and Development

The research and development identified under Phase 2 is performed in accordance with the approved R\&D plan. The R\&D program continues through the design phase (Phase 4) and possibly beyond.

\section{Phase 4 - System Design}

A preliminary design is prepared of the demonstrator system on the selected site.

Subphase 4.1 - Site selection - Several candidate sites are identified and the one best meeting the criteria developed under Phase 2 is sclected.

Subphase 4.2 - Preliminary Design - A preliminary design is prepared of the demonstrator system on the selected site. Subphase 4.3 - Detailed Desgin. - The detailed design of the demonstrator, consisting of drawings and specifications suitable for use in construction, is prepared and ducullenled, along with supporting design analyses. This subphase is paced by the progress of the research and development under phase 3 above, which will have been proceeding concurrently with Phase 4. 
Phase 5 - Demonstrator Construction

The demionstrator system is constructed. Data regarding construction costs, design feedback, and technological difficulties are collected, analyzed, and published in accordance with the program plan which was developed under phase 2.

Phase 6 - Demonstrator Operation

The demonstrator system is operated in accordance with the program plan. Data regarding the operation is collected, analyzed, and published in accordance with the program plan.

The costs of these programs vary widely. The most widely varying component is the research and development, phase 3 . In some cases, for example the viscosity-reducing additives discussed in section 8.3 below, a few hundred thousand dollars may be adequate. In other cases, for example internal cooling of IC engines, the $R \& D$ may run into the millions.

As noted above, Phase 1 has been identified in each case as the opportunity identification under this present study. Thus, the next phase for each of the programs is the concept validation phase, which is expected to consist of major subphases having the following objectives:

1) To validate the concept analytically and, in some cases, experimentally.

2) To prepare the system assessments which establish feasibility from several major viewpoints, e.g., technical, economic, environmental, etc.

3) To prepare any additional supporting studies and assessments which may be needed or desired, e.g., alternate approaches, alternate national policies, etc.

4) To identify the necessary experiments and tests and to formulate the plan for their performance

5) To define the complete R, D, \& D program and to formulate the complete detailed program plan.

Figure 3.0-1 presents a generalized Phase 2 schedule, in which the effort to achieve each of these objectives is designated as a subphase. The major second-tier subphases (tasks) under the primary subphases are also shown. The 12-month period indicated 


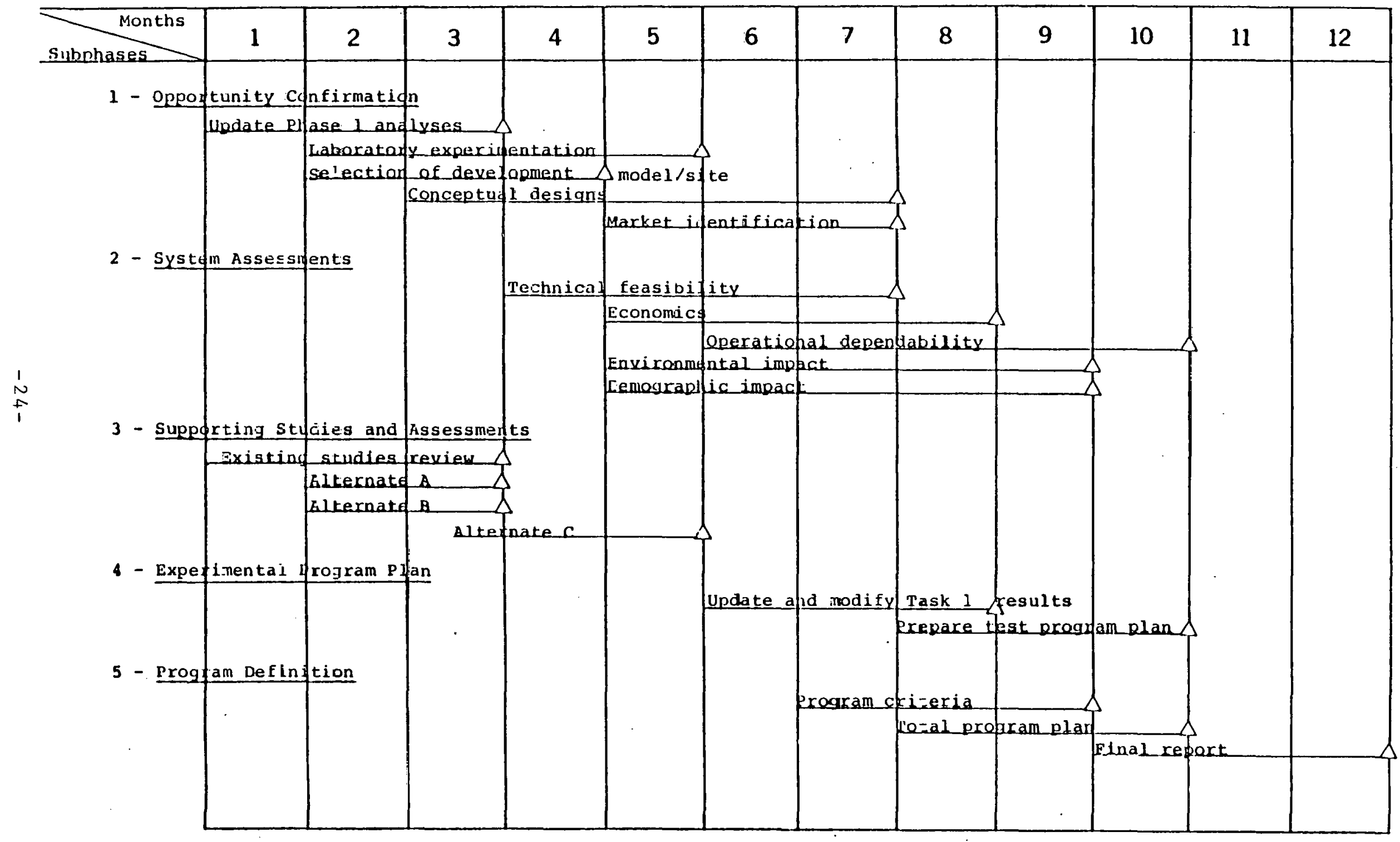

Fig. 3.0-1 - Generic Pháse 2 Schedule 
for completion may be shorter or longer for any specific program, depending upon its nature and the availability of funds. The magnitude of the total Phase 2 effort depends on the nature of the necessary input and of the laboratory experiments (Subphase 2) and/or supporting assessments (Subphase 3). In some cases, an adequate Phase 2 may be performed within two person-years of effort, while in others, four or five person-years may be necessary. For preliminary budgeting and planning an estimate of approximately three person-years is suggested.

4.0 POWER CONVERSION IMPROVEMENTS

The majority of the drivers, on prime movers, in gas pipeline service are reciprocating, spark-ignited, i.e., otto-cycle gas engines, fueled by natural gas from the pipeline. Prior to the Arab oil embargo, turbines had been entering service in increasing numbers, primarily because their lower maintenance was able to offset the higher efficiency of the reciprocators. In recent years, with the continued rise in gas prices, the turbines were the first to be taken out of service on those lines whose throughput has been declining. In an effort to reverse this trend, turbine manufacturers have initiated R\&D programs to improve turbine efficiency. As will be discussed later, two such improvements appear to offer a highly promising opportunity, yet appear to be beyond the development reach of industry.

Almost all prime movers on liquid pipeline are electric motors. As will be seen, there do not appear to be any allractive energy conservation opportunities in motor improvements.

4.1 Heat Engine Improvements

There are of course many small ways to improve the efficiency of heat engines. The engine manufactures are well aware of these potential improvements but do not incorporate them because they are not cost-effective under the existing fuel price structure. As fuel prices rise, more and more of these small improvements will be introduced. However, small improvements already under development by industry do not appear to offer attractive opportunities for 
DOE-sponsored R\&D. For the larger improvements which might justify DOE-sponsored $R \& D$, ie., step function improvements in performance, it is necessary to address the basic thermodynamic cycle, as opposed to small improvements in the hardware. Such basic cycle improvements are discussed below for the three principal engine types, i.e., Brayton, otto, and diesel.

\subsubsection{Braytion Engine Improvements}

The use of Brayton engines as gas turbines in gas pipelines has increased significantly in recent years. In particular, the two-shaft gas turbine driving a centrifugal compressor has gained increasing acceptance in the gas pipeline industry, for several good reasons.

(1) The gas turbine's natural characteristics match those of the centrifugal compressor. With the free power turbine coupled directly to the compressor load, both the turbine and the compressor have basically the same power to speed characteristics (see Fig. 4.1.1-1). The power absorbed by the centrifugal compressor varies approximately as the cube of the speed, and the output of the power turbine at best efficiency also varies essentially as the cuhe of the power turbine speed. The gas turbine and the centrifugal compressor can therefore operate at the same speed, thereby avoiding any necessity for reduction gearing and other complications. The normal pipeline operating 1 ine goes through the high efficiency points of the gas turbine (Fig. 4.1.1-2).

(2) The gas turbine has achieved a high degree of reliahilityavailability, longevity, and low maintenance. A continuing study by one of the major producers of industrial gas turbines in high use factor service has shown an average reliability of 99.58 and availability of $97.4 \%$. A significant percentage of the units in service have accumulated over 60,000, hours of operation and several units have surpassed 100,000 hours of operation. Reliability and availability in this instance are defined as follows: 


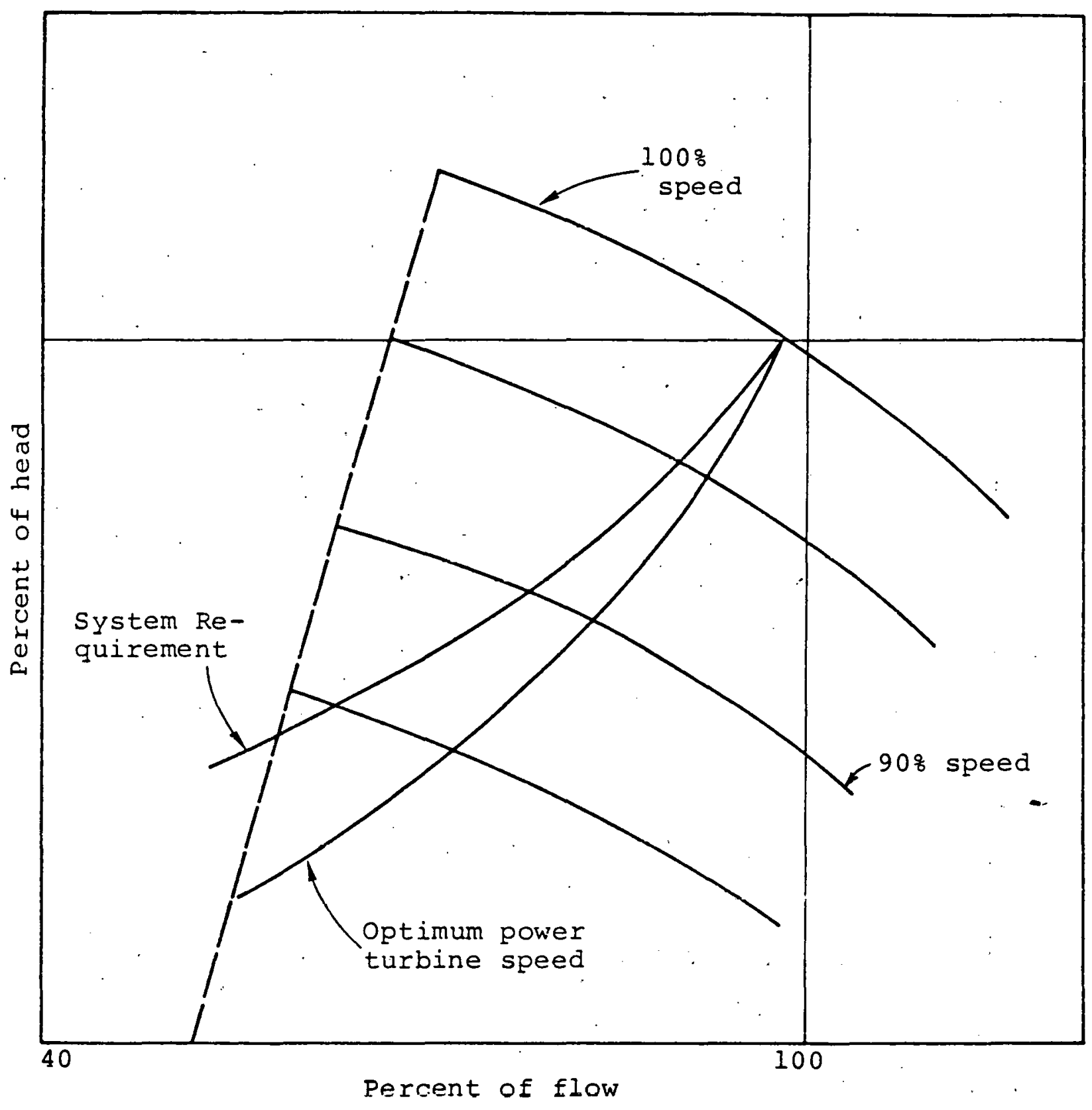

Fig. 4.1.1-1 Typical Centrifugal Compressor Characteristics Source: Reference 1 


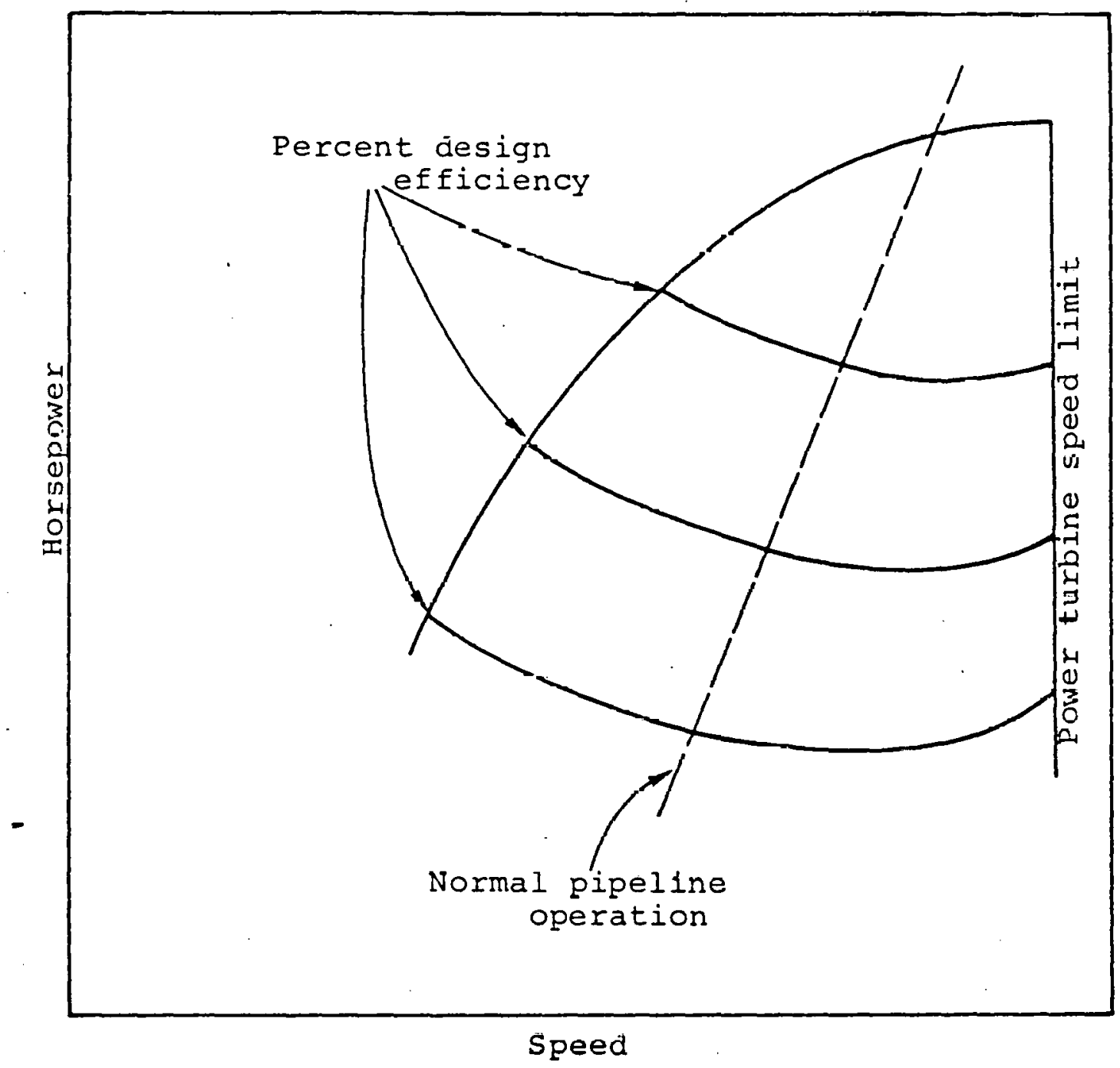

Fig. 4.1.1-2 Gas turbine performance match with pipeline requirements

Source: Reference 2 
Reliability $=$ installed hours less unsched. outage

installed hours

$\times 100 \%$

Availability = installed hrs.less (sched.\& unsched.outage)

installed hours

(3) The average cost per installed horsepower of the gas turbine compressor has proved to be significantly lower than that of comparable reciprocating type units. For example, in 1973, cost statements filed with the Federal Power Commission by 35 pipeline companies covering installation of 503,163 compressor horsepower ( $54 \%$ of which were gas turbine driven) showed an average cost per installed horsepower of $\$ 219$. for gas turbine units as compared with $\$ 295$ per installed horsepower for reciprocating units (Ref. 3 ).

The major disadvantage of the gas turbine as compared with the reciprocating engines used in gas pipelines is its higher fuel consumption. This, of course, is becoming a matter of increasing importance as the cost of fuel rapidly escalates. As a result, gas transmission companies as well as gas turbine manufacturers have been investigating ways of decreasing fuel consumption through modification of existing gas turbine installations and in applying gas turbines to new installations.

Advances in technology of simple cycle gas turbines have resulted in marked improvement in efficiency, with some of the newer industrial types approaching $30 \%$ overall thermal efficiency. However, with the cost of gas fuel increasing more rapidly than effiriency improvements in the simple cycle machines, it has become necessary to consider other approaches. The two foremost approaches for effecting major improvements in fuel economy are the use of regeneration, and the addition of a Rankine cycle bottoming plant to either simple cycle or regenerative cycle gas turbine power plants.

\subsubsection{Regenerative Cycles}

Figure 4.1.1.1-1 is a schematic representation of a regenerative cycle gas turbine power plant. The regenerator, which in the case of an industrial type gas turbine is a stationary heat exchanger (or recuperator), takes heat from the gas turbine exhaust and transfers this heat to the compressor discharge air before it enters the combustion chamber. 


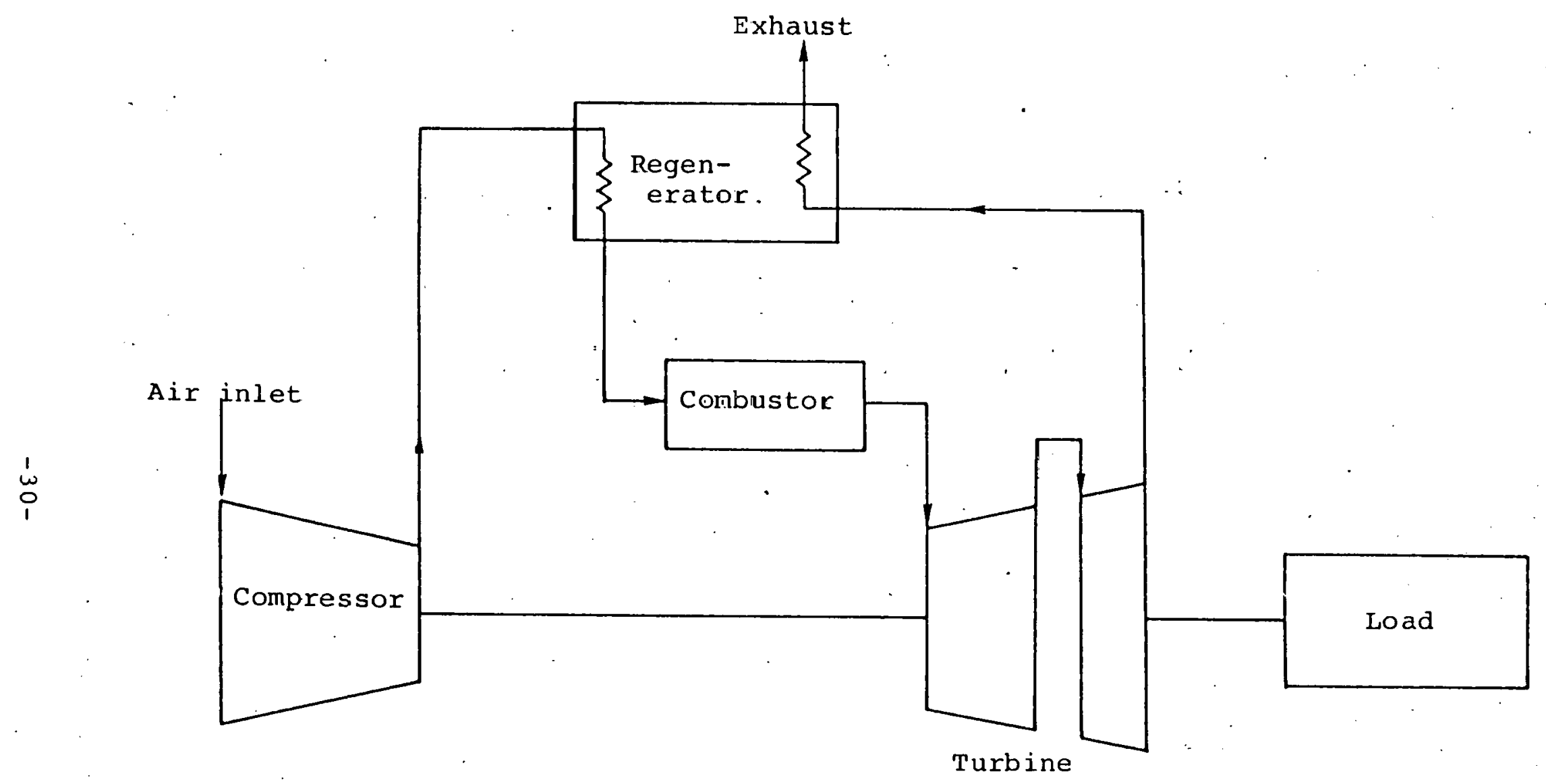

Fig. A.1.1.1-1 Two-shaft Regenerative Cycle Gas Turbine 
The use of regeneration is limited to gas turbine engines with moderately low pressure ratios. For a typical industrial gas turbine, a regenerator would be completely useless at pressure ratios of 14 or higher because the compressor discharge temperature is so high that it is equal to the exhaust temperature and therefore there is no chance for regeneration. The effect can be seen in Fig. 4.1.1.1-2. In most cases a pressure ratio of 6 to 8 represents a good compromise for both simple and regenerative cycle gas turbines, considering both fuel cost and installed first cost.

Addition of a regenerator of $80 \%$ effectiveness to a simple cycle two-shaft gas turbine increases thermal efficiency at full load by approximately 30\%. Regenerators with an effectiveness of approximately $81 \%$ have been used with gas turbines for some years. Higher efficiencies can be achieved by adding more heat exchange. surface to the regenerator, but only at the expense of considerable added bulk, weight, and cost. Figure 4.1.1.1-3 shows the effect of regenerator effectiveness on thermal efficiency and cost. When effectiveness is increased from 81 to $85 \%$, the heat exchange surface must increase approximately 50\%, and the additional regenerator surface costs about $\$ 150,000$. Analysis shows that for fuel costs between $\$ .50$ and $\$ 1.00$ per million BTU, the $81 \%$ is optimum. When fuel values reach $\$ 1.00$ to $\$ 1.50$ per million BTU, an effectiveness of $85 \%$ would be economical (Ref. 4).

\subsubsection{Brayton-Rankine Combined Cycles}

Fiqure 4.1.1.2-1 illustrates a combined cycle power plant in which a Rankine cycle system. is added as a bottoming plant to a simple cycle gas turbine. Exhaust heat from the gas turbine goes to a heat recovery boiler where vapor is generated and used to drive a turbine which is connected to the load. Exhaust from the vapor turbine is condensed and pumped back to the boiler to form a closed loop system. The single drive arrangement shown, with the vapor turbine directly connected to the outboard end of the load, 


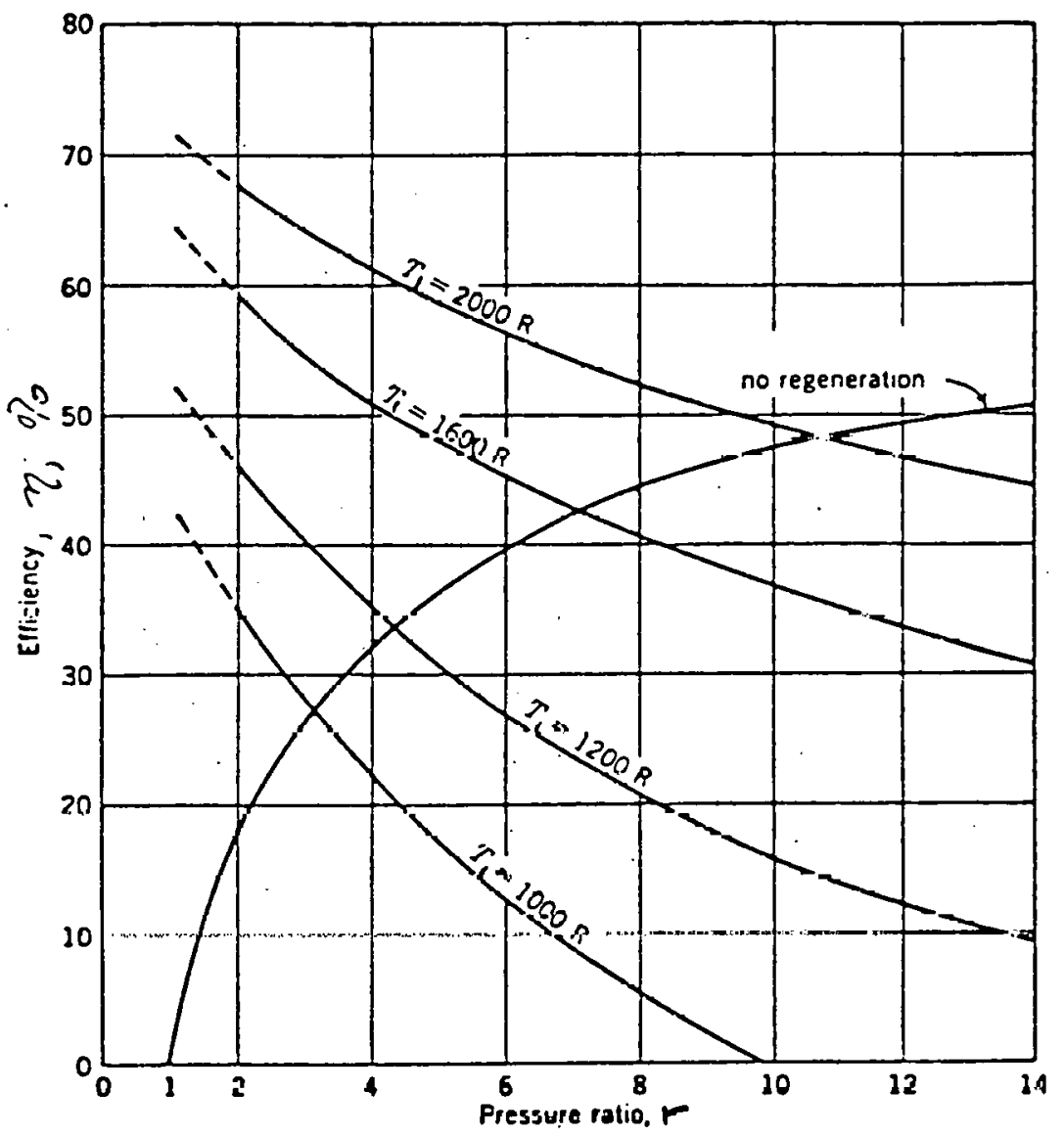

Fig. 4.1.1.1-2 Effect of pressure ratio in regenerative Brayton cycles

Source: Reference 4 


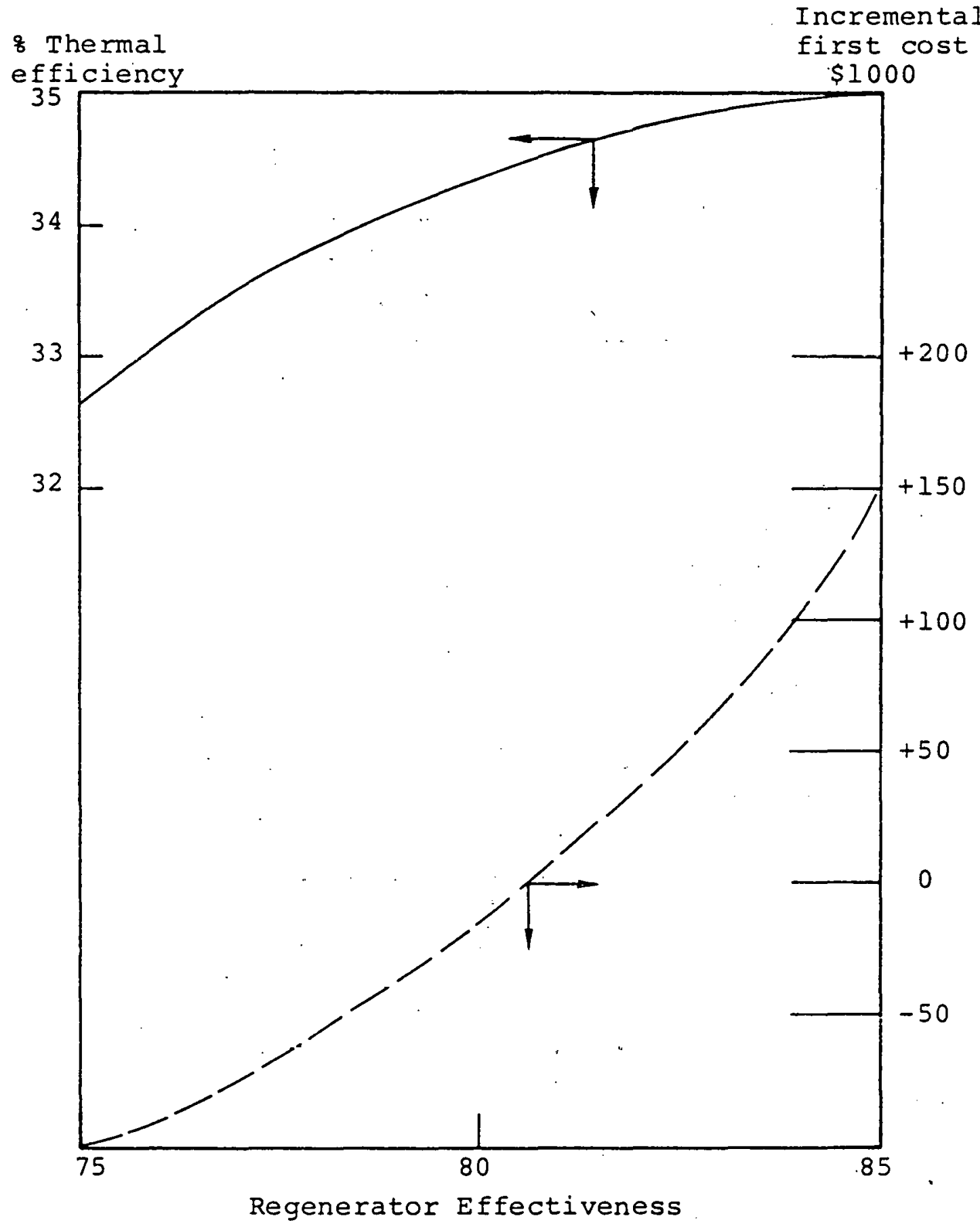

Fig. 4.1.1.1-3 Fiffects of regencrator effectiveness

Source: Reference 4 


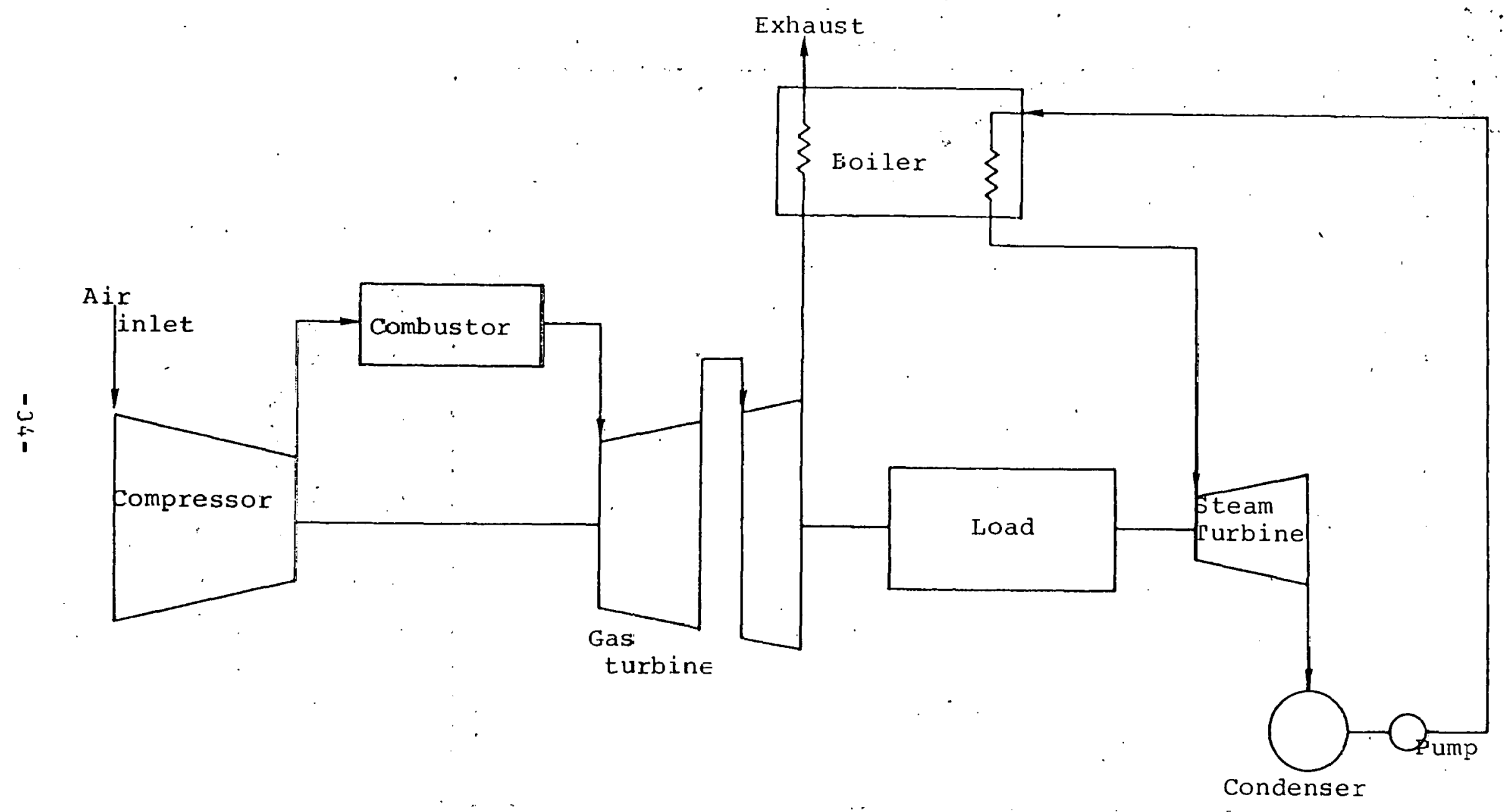

Fig. 4.1.1.2-1 Simple cycle gas turbinejRankine cycle combined power plant 
is advantageous in a pipeline application, since the vapor turbine can be designed. with an output speed to match the compressor and power output stage of the gas turbine. The gas turbine can also furnish the necessary speed control for both units under most conditions.

The number of combined cycle power plants installed to date is somewhat limited, and for the most part confined to large sizes in electric utility service. As far as this study could determine, only two plants of less than 15,000 $\mathrm{KW}$ capacity are in service in municipal utilities. The majority of the combined cycle plants in electric utilities are of the supplemental fired heat recovery type in which exhaust heat from the gas turbine is supplemented by separately fired burner.s in supplying heat to the boiler.

As for gas pipeline service, there are only four combined cycle systems known to be in operation. These systems were installed between 1968 and $19 \% \%$, and are reported to be operating successfully; however, with recent advances in technology, it is apparent that system efficiencies can be increased considerably:

The combined cycle system of most interest for pipeline service utilizes a simple cycle, two-shaft gas turbine exhausting its heat to an unfired heat recovery boiler. Studies by the General Electric Co. (Ref. 5) have indicated that such a system using a standard $14,600 \mathrm{hp}$ gas turbine and a steam turbine connected directly to a contrifugal compressor, can produce a combined output of $22,000 \mathrm{hp}$ at ISO conditions with an overall thermal efficiency of approximately $39 \%$.

Figure 4.1.1.2-2 (Ref. 5) shows estimated thermal efficiencies at varicus ambient temperatures for the above combined cycle system using water as the working fluid. Steady state conditions typical of normal pipeline compressor operation were assumed. 'l'hermal efficiency curves for a standard regenerative cycle gas turbine are shown for comparison. Two features of particular interest can be noted from these curves. 


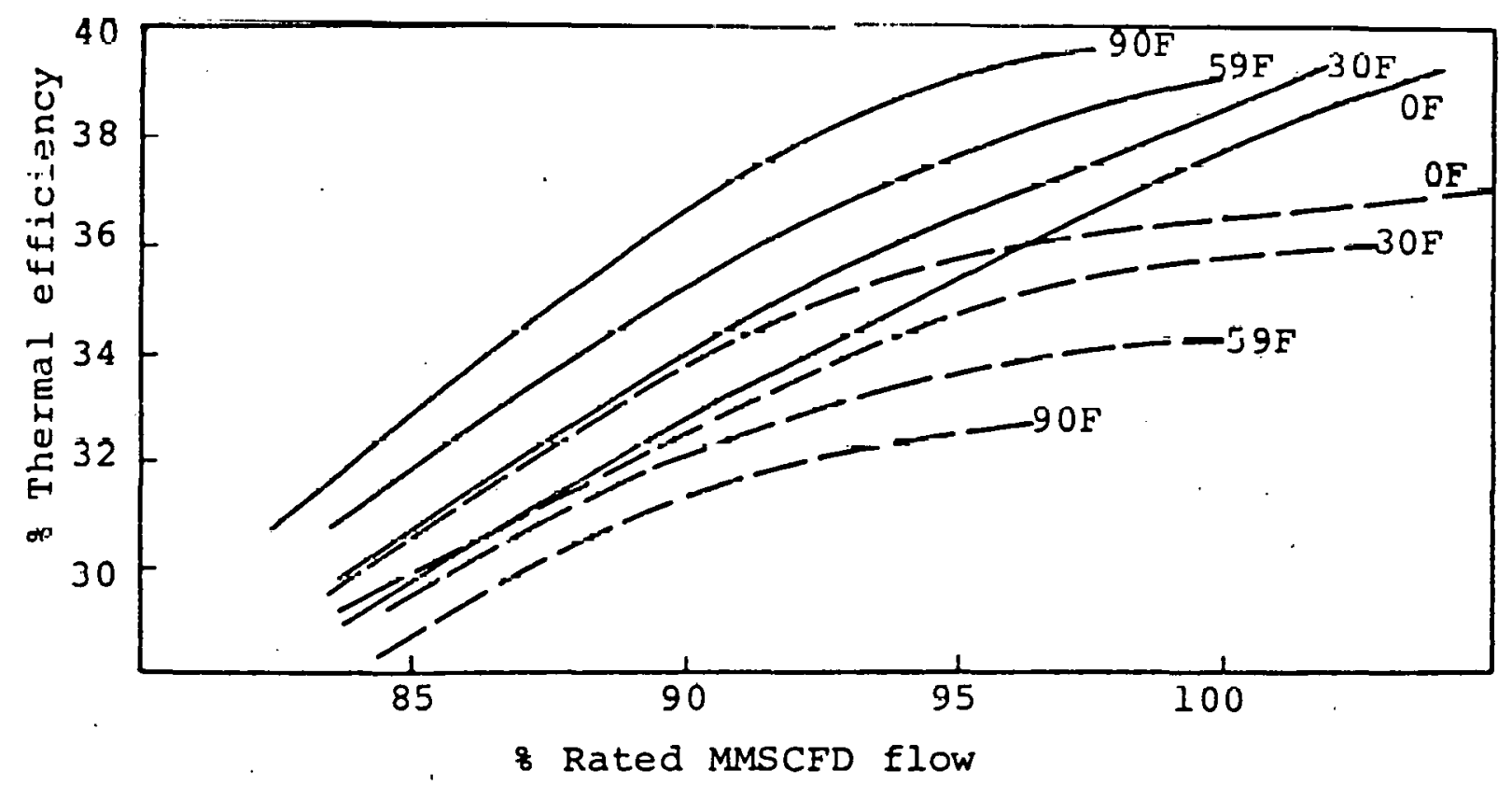

Fig. 4.1.1.2-2 Efficiencies of regenerative and combincd cycles

I

Single compressor combined cycle standara regenerative gas turbine

Source: Reference 5 
(1) The effect of varying ambient temperatures. At increasing ambients, the standard gas turbine efficiencies decrease significantly. For the combined cycle. , however, the efficiencies increase at higher anbient temperatures. At the $100 \%$ flow point and $59^{\circ} \mathrm{F}$, the combined cycle efficiency (39\%) is approximately $15 \%$ higher than that of the standard regenerative gas turbine (34\%).

(2) Part-load characteristics. The efficiency of the combined cycle plant decreases at a markedly higher rate at partial flows than that of the regenerative cycle plant. For example, at 85\% rated flow and $59^{\circ} \mathrm{F}$ (a condition which requires $55 \%$ of the Iso rated horsepower), the combined cycle efficiency drops to $32 \%$ as compared to $30 \%$ for the regenerative cycle turbine. This would indicate that the combined cycle plant is utilized to its best advantage when operating at high load factors.

Solar Division of International Harvester co. is actively investigating combined cycle power plants utilizing their industrial gas turbines in the 1200-10,000 hp range and expects to have initial field evaluation units in the 1978-79 era. Their studies. have indicated that a combined cycle system for small gas turbines would be noncompetitive in initial cost, performance, and operating characteristics if it were designed around commercially available steam turbines, boilers, condensers, and related equi prnent. Accordingly, they are undertaking the design and develpment of several major system components, described in a paper by solar (Ref. 6). They include:

(1) A once-through boiler, in which heating, boiling, and superheating take place in one tube. Steam drums are not used and feed water flows are controlled as a function of output steam conditions.

(2) A new steam turbine having a projected efficiency of $80 \%$. This compares with $66 \%$ in the best available commercial turbines. The new turbine concept is a z-stage type with the high pressure unit running $66,000 \mathrm{rpm}$ geared to a low pressure unit running at approximately $15,000 \mathrm{rpm}$, the same speed as the gas turbine drive. 
(3) New condensers ot both water-cooled and àir-cooled týpe. Utilizing these new components, solar is projecting combined cycle power plants having thermal efficiencies ranging from $34.9 \%$ for the Saturn engine to $41.8 \%$ for the new Mars engine which is currently being developed. The engines cover a horsepower range from 1160 to 10,300 in the simple cycle versions, and in the combined cycle versions will cover a range of 1824 to $13,790 \mathrm{hp}$. The performance of the combined cycle power plants represents an increase in ISO hp from 34-57\% and an improvement in fuel consumption of $25-38 \%$

The use of organic working fluids in the Rankine bottoming cycle offers potential for further improvement in efficiency of combined cycle power plants. Although all combined cycle plants constructed to date have used water as the working fluid, studies by Thermo Electron Corp. (Ref. 7) have indicated possible achievement of over $43 \%$ thermal efficiency in a simple cycle gas turblint organic Rankine cycle bottoming plant, and over $47 \%$ in a recuperated version of this plant. These studies are based on the use of current technology gas turbine engines in large power sizes (over $60,000 \mathrm{kw})$. Other advantages of organic working $t 1$ uids are low freezing temperature and possible reduction in size and weight, depending on the working tiuid used. 'lhere are disadvantages in organic fluids as well, in that many of those that are readily available are flammable or toxic and all are subject to decomposition at moderately high temperatures such as might occur in exhaust heat recovery boilers. Nevertheless, there appears to be enough potential to warrant further investigation of organic fluids in combined. cycle power plants.

\subsubsection{3 comparlson uf Gas Turbine Cyoles}

The decision to select a simple cycle, regenerative cycle, or combined cycle turbine power plant is sensitive to the duty cycle under which the plant will operate, the installed first cost of the equipment, the fuel cost, and the operating environment. 
With the rapid increase in fuel cost, the 25-28\% thermal efficiency of the typical present simple cycle gas turbine is probably not high enough to make this power plant competitive with the other plants in the future.

As mentioned previously, the combined cycle power plant has a decided advantage in efficiency at the higher ambient temperatures. This would be an important factor to consider in selecting a. plant to operate in a hot climate.

On the other hand, if the plant were required to operate a large part of the time at low load, the regenerative cycle turbine would appear to be more advanteageous since the rate of increase in specific fuel consumption at part loads is less. This is illustrated in Fig. 4.1.1.3-1, which shows part load characteristics of typical gas turbine engines in simple cycle, regenerative cycle, and combined cycle versions of the type used in pipeline service.

To compare the three cycles in a quantitative, precise way, detailed simulations were performed using the pipeline economic.. model (PEM) developed under Task 1 of this project and describe in References 8 and 9. The model was also introduced in Report HCP/M-1171-3, Section 7.1. The model is a simulator which accepts as input the design characteristics of the pipeline, the operating and capital costs, and a market (throughput) projection. Its output is the detailed financial and energy consumption history over the life of the project.

lhe reference pipeline used in the comparison studies was designed by $P$ ipetech and was based on earlier system designs from the Pipetech files. Some of these designs were actually built, and thus the reference designs for this study represent typical, realistic situations. The costs, derived by adjusting actual system costs, are therefore highly accurate in terms of this study. The rEM consists of two major submodels: a t'luidics submodel and a financial projection submodel. The gas dynamics of the line are calculated using a (proprietary) model previously developed by Pipetech and used by them in the design of actual pipelines. It is 


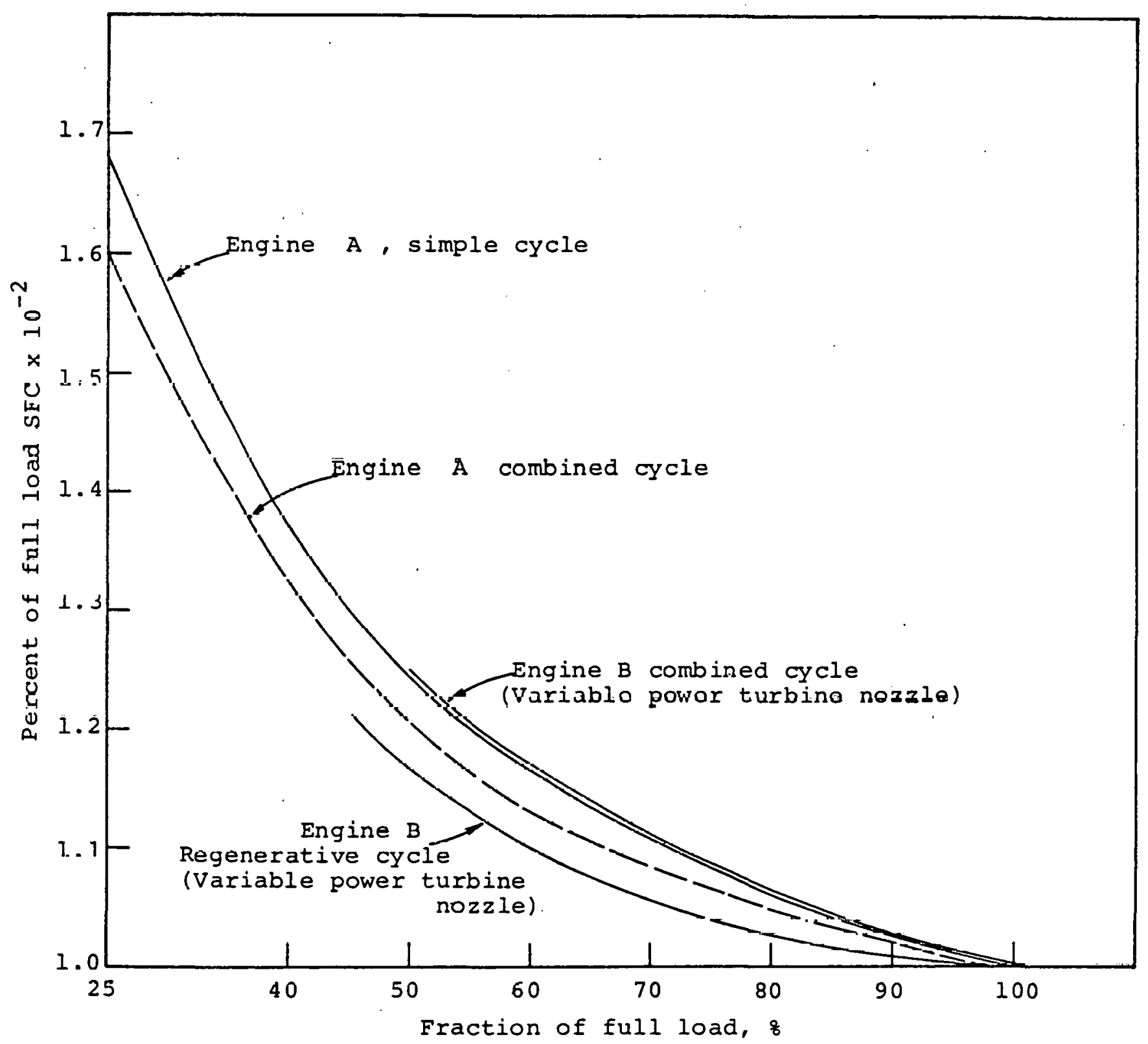

Fig. 4.1.1.3-1 Increase in specific fuel consumption at part load, typical two-shaft gas turbines 
therefore more than sufficiently accurate for this study. Figure 4.1.1.3-2 displays a typical output from the gas dynamics model. The financial projection model is an adaptation of a business projection model previously developed by $\mathrm{S} 3$, modified to reasonably simulate pipeline operation, and bench marked against a highly detailed pipeline-peculiar (proprietary) financial model previously developed by Pipetech.

The reference gas pipeline was designed and costed on the basis of reciprocating gas engines, since that approach represents the best current practice. An installation schedule was prepared for that system, detailing the points in the project life at which additional capacities must be installed. A survey of representative gas turbines was then made, and is presented in Table 4.1.1.3-1. The reference system was then converted from reciprocators in Tables $4 \cdot 1 \cdot 1 \cdot 3-2$ and $4 \cdot 1 \cdot 1 \cdot 3-3$, respectively. The heat rates were then adjusted from the full-load values to those associated with the actual operating horsepowers required, using the part-load characteristics from Fig. 4.1.1.3-1.

For purposes of the comparison, the simple cycle is regarded as the baseline. The output from the economic model for this case is shown in Fig. 4.1.1.3-3. Figure 4.1.1.3-4 presents the output for the combined cycle. For the comparison, the total costs are taken to be equal for both cases. Thus, the question being asked of the model is, if these improved cycle engines could be installed and operated at the same cost as the simple cycle, what would be the benefit? With this information, it is possible to calculate the operator's incentive in energy and dollar savings to adopt the innovations. It is noted that although the total costs input for the two cases are the same, the capital infusion rates are different, reflecting the differences in timing for capacity additions. Some of the more important inputs and assumptions are listed in Table 4.1.1.3-4. Table 4.1.1.3-5 presents some significant figures, extracted from the two outputs. 


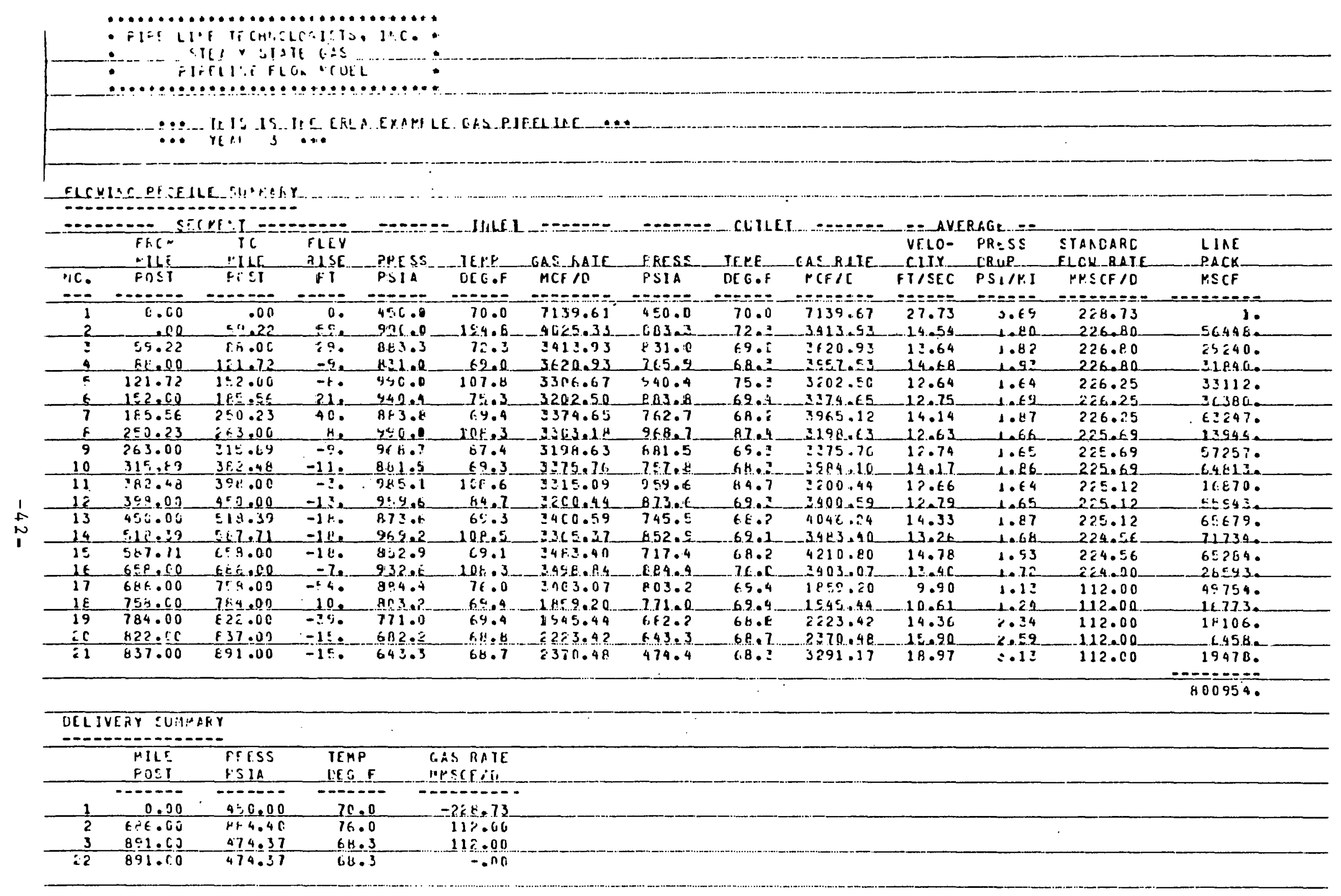

Fig. 4. 1.1.3-2(3) Typical output, gas dynamics submodel 


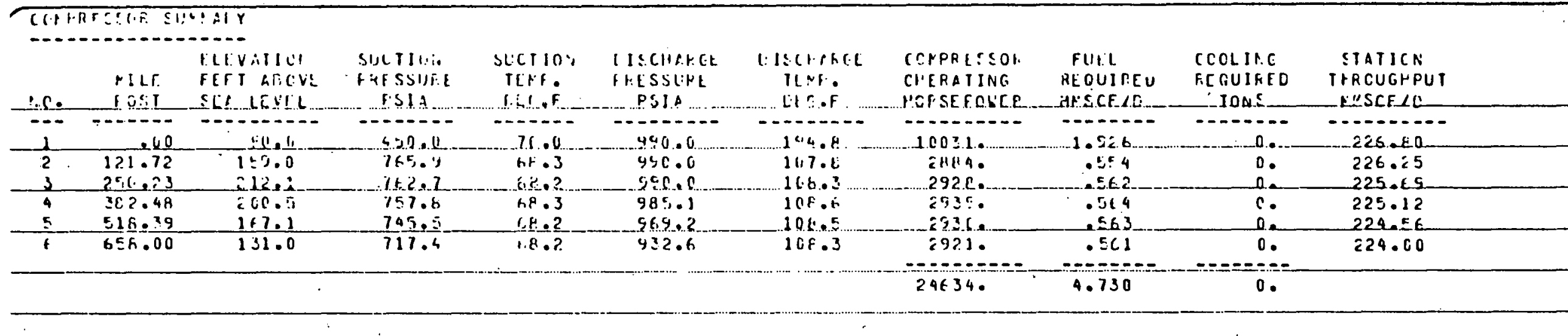

Fig. 4.1.1.3-2(b) Typical output, gas gynamics submodel 
Table $4.1 \cdot 1 \cdot 3-1$

REPRESENTATIVE GAS TURBINES

IN GAS PIPELINE COMPRESSOR SERVICE

\begin{tabular}{|c|c|c|c|c|c|c|c|}
\hline anufacturer & Model No. & Rating & $\mathrm{BTU} / \mathrm{HP}-\mathrm{hI}$ & Rating & $\mathrm{BTU} / \mathrm{HP}-\mathrm{hI}$ & Rating & $\mathrm{BTU} / \mathrm{HP}-\mathrm{hI}$ \\
\hline Solar & Saturn & 1160 & 11600 & 1100 & 9510 & 1804 & 7284 \\
\hline Solar & Centaur & 3830 & 9600 & $3580^{1}$ & $8100^{1}$ & 5600 & 6578 \\
\hline Solar & Centaur ${ }^{3}$ & 4850 & 9100 & 4540 & 7460 & 7090 & 6288 \\
\hline Solar & $\operatorname{Mars}^{3}$ & 10300 & 8080 & 9630 & 6625 & 13680 & 6080 \\
\hline Allison & $501 K 5$ & 2745 & 11070 & 2600 & 9080 & 4120 & 7370 \\
\hline Allison & $501 \times 13$ & 3165 & 9980 & 3000 & 8180 & 4750 & 6650 \\
\hline $\begin{array}{l}\text { Cooper- } \\
\text { Bessemer (P\&W) }\end{array}$ & RT25 (GG12) & 2750 & 13800 & 2600 & 11315 & 4125 & 9190 \\
\hline $\begin{array}{l}\text { Cooper- } \\
\text { Bessemer } \\
\text { (Rolls Royce) }\end{array}$ & $\begin{array}{l}\text { COB125 } \\
\text { (AvOn) }\end{array}$ & 12500 & 9800 & 11875 & 8035 & 18750 & 6525 \\
\hline Delaval & Turbopac & 3300 & 11600 & 3130 & 9510 & 4950 & 7725 \\
\hline $\begin{array}{l}\text { Ingersell } \\
\text { Rand }\end{array}$ & $\operatorname{Gr} 40 / 22$ & 4250 & 9430 & 4040 & 7730 & 6375 & 6280 \\
\hline $\begin{array}{l}\text { General } \\
\text { Electric }\end{array}$ & $\begin{array}{l}\text { Frame } 3 \\
(\text { Mod. } 3000)\end{array}$ & 6850 & 11000 & $6850^{1}$ & $9000^{1}$ & 9800 & 7690 \\
\hline $\begin{array}{l}\text { General } \\
\text { Fipertric }\end{array}$ & M3872 & 8780 & 10850 & 8730 & 9000 & 13125 & 7225 \\
\hline $\begin{array}{l}\text { General } \\
\text { Electric }\end{array}$ & M3102 & 10800 & 10190 & 10800 & 9000 & 16200 & 6785 \\
\hline $\begin{array}{l}\text { General } \\
\text { Elcctrio }\end{array}$ & M3132 & 13100 & 9760 & 13100 & 9000. & 19650 & 6500 \\
\hline Orenda & OT 370 & 8890 & 11800 & 8200 & 9675 & 13325 & 7860 \\
\hline Orenda & $O T-F-270$ & 9830 & 11550 & $9070^{1}$ & $7770^{1}$ & 14745 & 7690 \\
\hline
\end{tabular}

Regenerative (Estimated) ${ }^{2}$

Simple Cycle HP(ISO) SFC

Cycle

HP(ISO) SFC

Combined Cycle

HP (ISO) SFC

Rating BTU/HP-hI 
Table $4 \cdot 1 \cdot 1 \cdot 3-2$

REFEREINCE GAS SYSTEM CONVERSION

RECIPROCATORS TO SIMPLE-CYCLE TURBINES

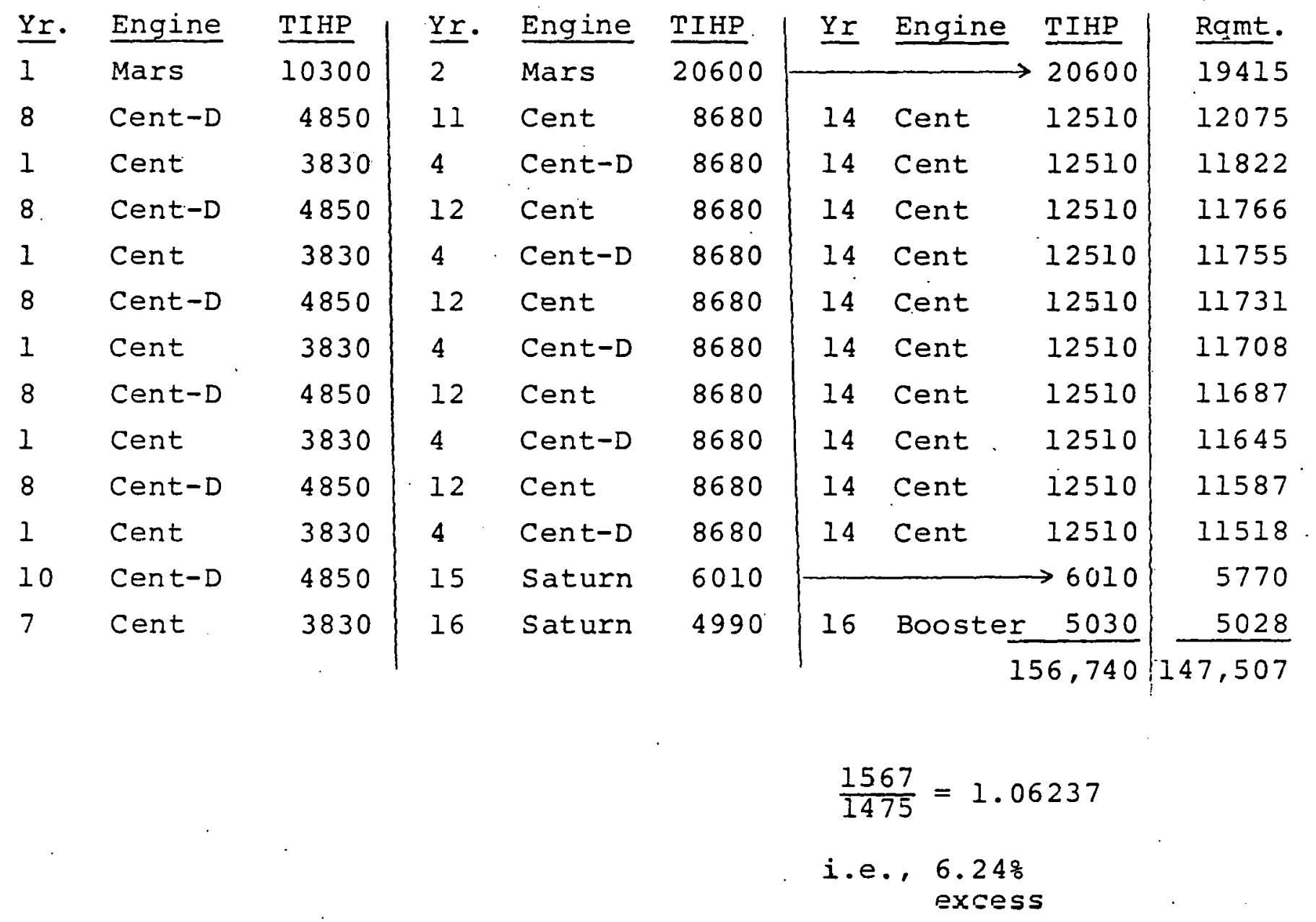




$$
\text { Tahle } 4.1 .1,3-3
$$

REFERENCE GAS SYSTEM CONVERSION RECIPROCATORS TO COMBINED-CYCLE TURBINES

\begin{tabular}{|c|c|c|c|c|c|c|c|}
\hline st. & $\underline{Y r}$. & Engine & TIHP & $\underline{Y r}$. & Engine & TIHP & RQMT. \\
\hline 1 & 1 & Mars & 13680 & 7 & Cent-D & 20770 & 19415 \\
\hline 2 & 8 & Cent & 5600 & 12 & Cent-D & 12690 & 12075 \\
\hline 3 & 1 & Cent & 5600 & 6 & Cent-D & 12690 & 11822 \\
\hline 4 & 8 & Cent & 5600 & 12 & Cent-D & 12690 & 11766 \\
\hline 5 & 1 & Cent & 5600 & 6. & Cent-D & 12690 & 11755 \\
\hline 6 & Same & as st & 2 & & & $\rightarrow 12690$ & 11731 \\
\hline 7 & & & 3 & . & - & $\rightarrow 7.2690$ & . 11708 \\
\hline 8 & & & 2 & $\cdots$ & $\longrightarrow$ & $\rightarrow 12690$ & 11687 \\
\hline 9 & & & 3 & 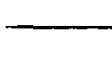 & $x_{2}$ & $\rightarrow 12690$ & 11645 \\
\hline 10 & & & 2 & $-\ldots . . . \cdots$ & 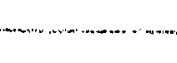 & $=12690$ & 11587 \\
\hline 11. & & & 3 & & & 12690 & 11518 \\
\hline 12 & 10 & Cent $=0$ & 9090 & $\begin{array}{l}\text { No } \\
\text { ins }\end{array}$ & $\begin{array}{l}\text { rther } \\
\text { llatn. }\end{array}$ & 7090 & \\
\hline 13 & 7 & Cent & 5600 & $"$ & $"$ & 5500 & .5028 \\
\hline & & & & & & 160,360 & 147,500 \\
\hline \multicolumn{8}{|c|}{$\frac{160,360}{147,507}=1.0871$} \\
\hline & & & & & & i.e., 8 & \\
\hline
\end{tabular}


SYSTEMS, SCIENCL AND SOFT NAFE

LAC PHOJECTION MUDEL

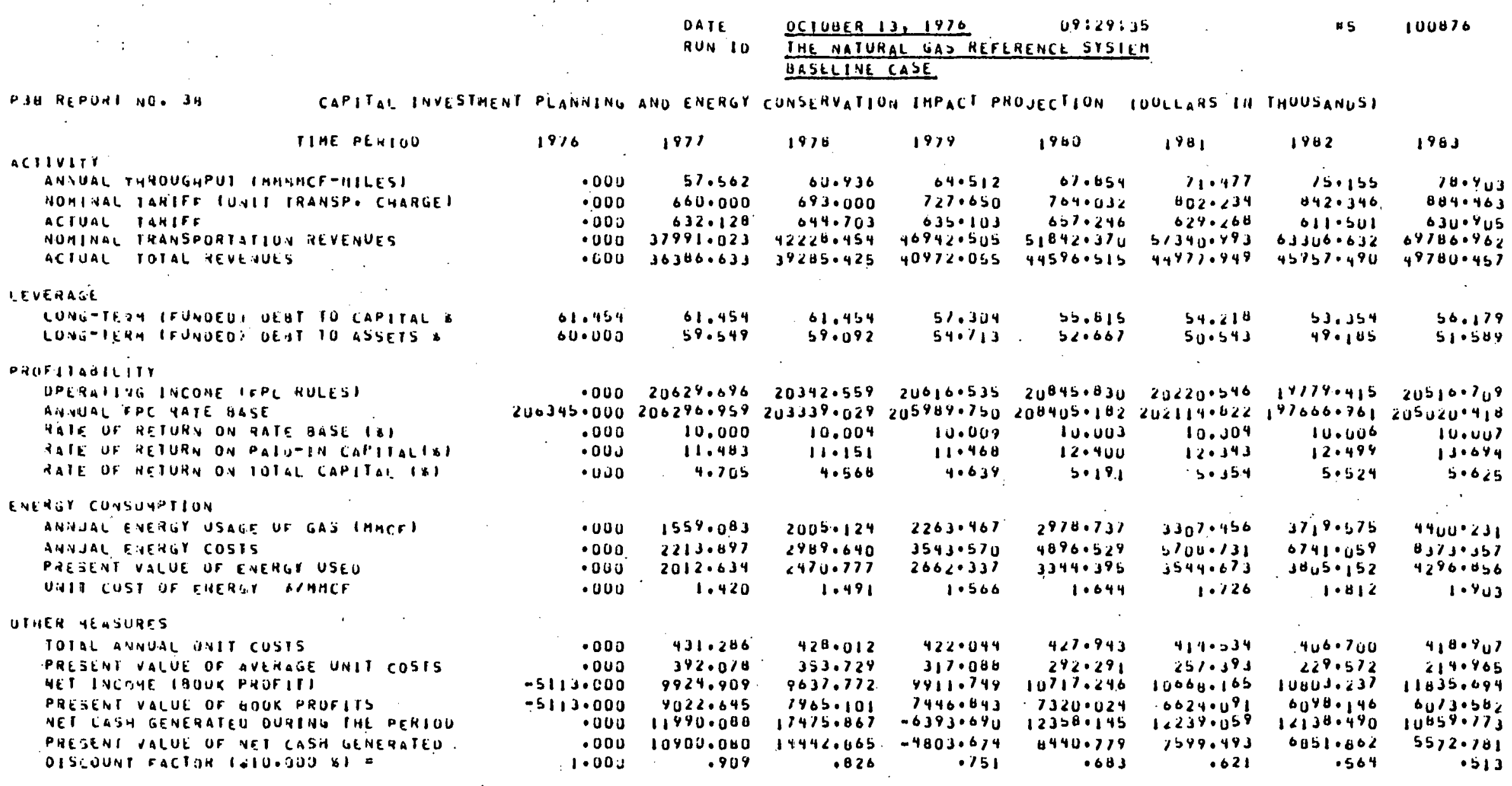


SYSIEHS, SCIENCE AHU SOFINARE

LAC PROJECTICH MUUEL

PIPELINE IRANSPORTATIUN SYSIEHS ENERG CONSERVATION JIUUR

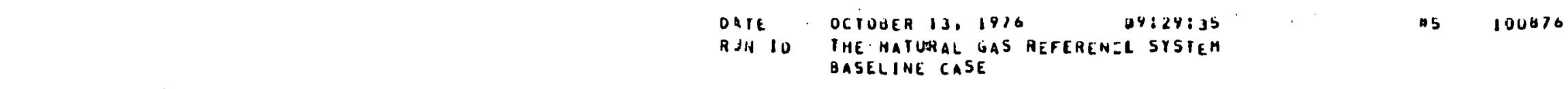

pin HEPUAt No. Ba

CAPITAL INVESTMENT PLANNIMG ANU ENERGT CONSERVAIION IHPACT PNOJEE ION IOULLAHS IHE IHUUSANUS.

activitr IIME PEIIUO

$19 E 4$

1985

AHNIAL THROUSHPUT ABHAHEF-HILESI

NUAIVAL TIATIEE TUNIT IRANSP. CHARGE.

ACIUAL IAHIFE

MOHINAL T.AANSPURIQTIUT TEYENUES

aCTUAL TOTAL REVEVUES

I.EVERAGE

LUVG-TELY IFUNDEUI DEST TO CAPIIAL

LOVG-IERA (FUNDEU) OEOT TO ASSETS

DROFITABILITY

OPERATING INEOME IFPC RILLE'

ANTUAL TPC RATE BASE

MATE UF TEIURA ON RATE GASE IBI

RATE OF HEIURN IIN PAIO-IN CAPIRALIOL

AAIE UF RETURY ON TOIAL CAPITAL. I8I

EVERGT CONSUMPIION

AHYUAL ENERGY USAGE UF LAS (MMCE)

ANTUAL SNERGY COSTS

PHESENI VALUE OF ENERIS USIL

UNIT CUST OF ENEKLY BAHCF

OIHEH MEASUHES

TOIAL. HVINUAL IINII COSIS

PRESEnt value uf average uidit costs

NEI INCTNE IBJUK PROFIT]

PRESENI VALUE OF EOOK PROEII"

NEI CASH GENERATEL OURING TIIE DERIOU

PAESENT VaLUE OF NET CASH WENEHATEL

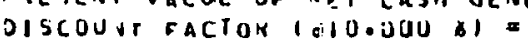

$\begin{array}{rr}61.036 & 85.513 \\ 9280686 & 975.121 \\ 637.801 & 632.150 \\ 75959.433 & 83383.770 \\ 52155.564 & 54653.833\end{array}$

$1986^{\circ} \quad 1987$

$17 \cdots$

1709

1940

1991

\subsection{877}

920843

$1075 \cdot 070$

$6.280 \quad 100.124$

$1120.024 \quad 11950263$

$7: 0.195 \quad 701.013$

$701 \cdot 613$
6674.064

$101.59 \%$

$1244.52^{\circ}$

60703.14260303046 70248.080 02048.646

100.413

1306.755

828.099

\begin{tabular}{|c|c|c|c|c|c|c|c|}
\hline $\begin{array}{l}54 \cdot 6.26 \\
49 \cdot 367\end{array}$ & $\begin{array}{l}58.229 \\
53.502\end{array}$ & $\begin{array}{l}57.177 \\
50.921\end{array}$ & $\begin{array}{l}520810 \\
46.547\end{array}$ & $\begin{array}{l}51.496 \\
14.078\end{array}$ & $\begin{array}{l}59.234 \\
51.487\end{array}$ & $\begin{array}{l}38.329 \\
50.325\end{array}$ & $\begin{array}{l}50 \cdot<86 \\
4 \% \cdot 639\end{array}$ \\
\hline $\begin{array}{l}0: 3 \cdot 3.34 \\
1 \leq 0 \cdot 463\end{array}$ & $\begin{array}{r}20771.450 \\
207645.766\end{array}$ & $\begin{array}{r}20692.507 \\
200765.298\end{array}$ & $\begin{array}{r}20915.106 \\
206959.906\end{array}$ & $\begin{array}{r}20^{4}+3 \cdot 534 \\
2091+8 \cdot 326\end{array}$ & $\begin{array}{r}225,90146 \\
2250790184\end{array}$ & $\begin{array}{r}242<5 \cdot 12 Z \\
24<0<2 \cdot 132\end{array}$ & $\begin{array}{r}236560.077 \\
2364450479\end{array}$ \\
\hline $\begin{array}{r}10.004 \\
12.497 \\
=.528\end{array}$ & $\begin{array}{l}13.003 \\
1.373 \\
5.111\end{array}$ & $\begin{array}{r}10.008 \\
11.157 \\
4.349\end{array}$ & $\begin{array}{l}10.009 \\
12.208 \\
4.770\end{array}$ & $\begin{array}{r}10.000 \\
13.022 \\
b .230\end{array}$ & $\begin{array}{r}10.005 \\
15.412 \\
5.202\end{array}$ & $\begin{array}{r}10.009 \\
13.605 \\
4.684\end{array}$ & $\begin{array}{r}10.1505 \\
13.462 \\
4.829\end{array}$ \\
\hline $\begin{array}{r}446 t .0495 \\
89: 4.424 \\
4105.0110 \\
1.996\end{array}$ & $\begin{array}{r}4920.097 \\
10322.249 \\
4377.062 \\
2.548\end{array}$ & $\begin{array}{r}5284.936 \\
11604.140 \\
4497.031 \\
2.203\end{array}$ & $\begin{array}{r}0103.640 \\
14302.846 \\
5013.046 \\
2.313\end{array}$ & $\begin{array}{r}6942,746 \\
16831.721 \\
5312.664 \\
2.429\end{array}$ & $\begin{array}{r}7740.591 \\
18739.403 \\
5717.002 \\
2.550\end{array}$ & $\begin{array}{r}9563.021 \\
25006.150 \\
0742.942 \\
2.070\end{array}$ & $\begin{array}{r}14614 \cdot 371 \\
29642 \cdot 332 \\
7144 \cdot 117 \\
2 \cdot 412\end{array}$ \\
\hline $\begin{array}{l}43 \% .672 \\
204.17 \%\end{array}$ & $\begin{array}{l}445.519 \\
18.9 .111\end{array}$ & $\begin{array}{l}472.508 \\
182.200\end{array}$ & $\begin{array}{l}481.001 \\
168.026\end{array}$ & $\begin{array}{l}486.255 \\
150.122\end{array}$ & $\begin{array}{l}527.446 \\
152.782\end{array}$ & $\begin{array}{l}019.83 .9 \\
163.221\end{array}$ & $\begin{array}{l}644.491 \\
154 \cdot 286\end{array}$ \\
\hline $\begin{array}{r}1253.641 \\
5210.577 \\
14200.634\end{array}$ & $\begin{array}{r}1555.754 \\
4901.703 \\
35462.175\end{array}$ & $\begin{array}{l}9643.312 \\
3717.914 \\
8011.928\end{array}$ & $\begin{array}{r}10551.332 \\
3698.178 \\
-3125.719\end{array}$ & $\begin{array}{r}11235.100 \\
3536.247 \\
164 \$ 9.091\end{array}$ & $\begin{array}{r}13520.435 \\
5858.450 \\
11640.094\end{array}$ & $\begin{array}{r}1768.539 \\
3046.398 \\
10520.718\end{array}$ & $\begin{array}{r}11.634 .471 \\
2785.520 \\
10690.541\end{array}$ \\
\hline 6613.361 & 150319.424 & $3091.25 \mathrm{E}$ & -1045.545 & 5227.119 & $3109 \cdot 681$ & $4 ذ$ & $2 b 39.23 i$ \\
\hline .467 & .424 & .386 & ט מנ - & .314 & .290 & .263 & .239 \\
\hline
\end{tabular}


SYSTEAS, SCIENCE ANU SOFIWARE

LAC PAOJECIION MUOEL

PIPELINE IRANSPOKTAIION SYSTEMS ENERGY CONSERVAIION SIUUT

$$
\begin{aligned}
& \text { OATE OLTOQER 13.1916 U9:29:35 } \\
& \text { RUN } 10 \text { THE NATURAL GAS KEFLRENCE STSTEM } \\
& \text { HASELINE CASE }
\end{aligned}
$$

pjo hepunt nu. Ja

CAPIIAL INVESTHENT

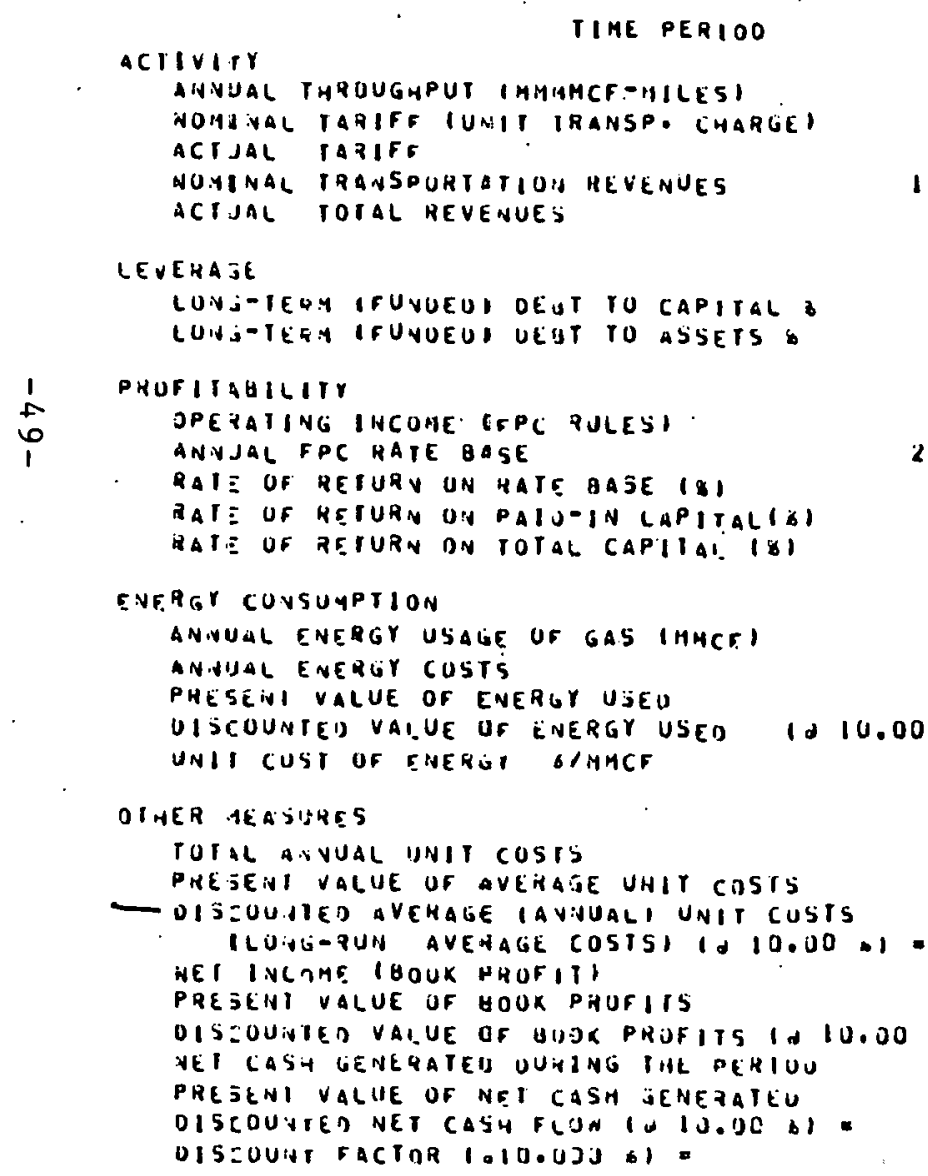

1992

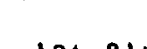

372.092
154.543

46690.373

91359.193

$\begin{array}{cr}53.726 & 50.661 \\ 44.464 & 40.466 \\ & \\ 2923.784 & 21989.547 \\ 291020648 & 219746.439 \\ 10.006 & 10.007 \\ 13.684 & 13.737 \\ 5.158 & 5.534 \\ & \\ 0660.011 & 10660.011 \\ 1469.182 & 33042.641 \\ 6848.611 & 6537.311 \\ 110 & 46433.670 \\ 2.452 & 3.100\end{array}$

1993

ANAJAL THROUGHPUT IAMIAMCF -HILES

ACIJAL TAZIFE

ERA

LONJ-TEQY IFUNUEUI DEUT TO CAPITAL

TISTILITY

DPETATING INCOAE IFPC PJLESI

ANINJAL FPC RATE BASE

QAIE OF RESURY UN HATE GASE (\&

AATE OF KETURN ON PAIU-IN LAPITALIOS

Gét CUNSUYPTION

ANMUAL ENERGY USALE UE GAS IMNCEI

anidial ENERGOr custs

106.910 ab

100870

ONSERVATION IMPACT PHUJECIION IOULLARS IN IHUUSANUSI

1994

1985

1946

IUIAL

AVELAGE

$106.910 \cdot 106.910$
1512.732
1580.368

$106.810 \cdot 1767.152$

$1607.787 \quad 21023.527$

$\begin{array}{rrrrr}1512.732 & 1580.368 & 1607.727 & 21023.527 & 1441.116 \\ 4.86 .897 & 905.715 & 924.882 & 14132.206 & 706.610\end{array}$

$870.033 \quad 0.86 .897 \quad 9050715$

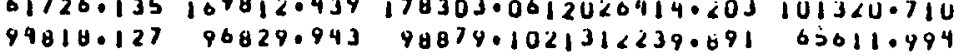

40.01000

\subsection{0}


UTHER LINE ITEMS

IIAE PE \$100

OPERAIION AND MAINTEVANCE EAPENSES INIEREST EXPENSES TUIAT EXPENSES UNUSEU TAX LO.5S UNUSEO TAVESTMENT IAX CHCOITS LONG-IEHA BORRONING NET AOUIIIONS 10 ERUIT LOUITIJNS TO PLANT G EJULPAENT LOVG-IEAY DEHI HEIIREMENI PLANT G EJUIPAENT ID URIGINAL CUSTI NEI PKUPEPIY \& EQUIPMENI TOTAL UEBT BALA.AHCE

IOIAL EOUIIY CAEIIAL

IIME PERIOO

OTHEH LINE ITEMS OPEIIAIITN ANO INIEAESI EXPENSES TUIAL EXPENSES

UNJSEU TAX LOSS

UNUSEO INVESTMENT IAX CREOIIS

LONG-IEAH BOAROWIAG

NET AOUITIUNS TO EQUIIY

AOMIJTONS TO PLANT S EQLIP.YENI

LONG-IERY OEBI RE-IRENEYI

PLAIIT EQUIFAENT D ORISINAL CISTI

NEI PRUPERTY S EUU PHENI

TOTAL UEAT SALIAVCE

TUTAL EQUIIOC CAPITAL

TIME PERITO

WTHER LIVE ITEMS

OPERAIIUN ANO MAINTENANCE EXPENIES

INIEAEST EXPENSES

$$
\text { IOI AL EXPENSES }
$$

UNUSEO. INVESTMENT TAX CHEUITS

CONG-TEYA BORHONI +6

ME 1 AJUITIONS TO EDUITY

ADUIIIOYS 10 PLANT G EQUIPIAENT

LONG-IETY OEAT PETIREMLNT

PLANT EOUIPYENT ID UREGLI:AL COSTI

NE PHUPEPTY EJUIPAENT

TOTAL DEAT BALAHCE

TUTAL EOUITY CADIIAL

\begin{tabular}{|c|c|c|c|c|c|c|c|c|}
\hline 1970 & & 1977 & 974 & 974 & 980 & 981 & $1+02$ & 1485 \\
\hline • & $\begin{array}{l}.000 \\
.00 \mathrm{j}\end{array}$ & $\begin{array}{r}6242.000 \\
0371.640\end{array}$ & .000 & 7 & $\begin{array}{l}000 \\
445\end{array}$ & & $\begin{array}{l}8.000 \\
130040\end{array}$ & \\
\hline & & & 204 & & 7.474 & 9.473 & $5.54 y$ & 3.495 \\
\hline & .0 & & & & & & & \\
\hline 385 & 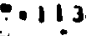 & .00 & .000 & & & & - vuo & - UuU \\
\hline $\begin{array}{l}196 \\
164\end{array}$ & 0 & $\begin{array}{l}.00 \\
.00\end{array}$ & $\begin{array}{l}.000 \\
.000\end{array}$ & & & & $\begin{array}{r}\Delta 513.000 \\
\text {.000 }\end{array}$ & $\begin{array}{r}21061.000 \\
.000\end{array}$ \\
\hline & $\begin{array}{l}1.000 \\
.000 \\
1.000\end{array}$ & $\begin{array}{r}5509.000 \\
2005120000\end{array}$ & $\begin{array}{r}.000 \\
0000 \\
095120000\end{array}$ & $\begin{array}{r}109 \\
72 \\
2264\end{array}$ & $\begin{array}{l}.000 \\
2.533 \\
3.000\end{array}$ & $\begin{array}{r}.000 \\
02.53 j \\
53.000\end{array}$ & 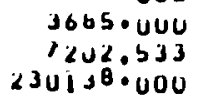 & $\begin{array}{r}23705 \cdot 0 u 0 \\
7202,5 J 3 \\
253430000\end{array}$ \\
\hline 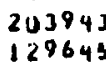 & $\begin{array}{l}3.000 \\
3.000\end{array}$ & $\left\{\begin{array}{l}3446.910 \\
4645.600\end{array}\right.$ & $\begin{array}{r}8027.141 \\
9045.6000\end{array}$ & $\begin{array}{l}20^{9} 1 \\
1224\end{array}$ & $\begin{array}{l}.002 \\
.533\end{array}$ & $\begin{array}{l}.041 \\
1.000\end{array}$ & $\begin{array}{l}0.279 \\
3.467\end{array}$ & 21 \\
\hline al & 7.400 & .400 & 7.400 & 91229.148 & $4 \cdot 148$ & - 148 & 0148 & 0.069 \\
\hline 1985 & & & & & & & & \\
\hline $\begin{array}{r}100 \\
94 \\
350\end{array}$ & (3) & $\begin{array}{l}.000 \\
.0252 \\
.983\end{array}$ & $\begin{array}{l}1.000 \\
6.056 \\
1.003\end{array}$ & $\begin{array}{l}120 \\
100 \\
442\end{array}$ & $\begin{array}{l}4.000 \\
5.215 \\
3.213\end{array}$ & $\begin{array}{r}16038.000 \\
\forall 005 \cdot 572 \\
5 \angle 010.252\end{array}$ & $\begin{array}{l}\text {.000u } \\
3.450 \\
3.716\end{array}$ & $\begin{array}{l}171930.404 \\
11684.767 \\
644040510\end{array}$ \\
\hline & $\begin{array}{r}.000 \\
.000\end{array}$ & .04 & $\begin{array}{l}.000 \\
.000\end{array}$ & & & & & \\
\hline & $\begin{array}{l}.000 \\
.000\end{array}$ & $\begin{array}{r}4.000 \\
.000\end{array}$ & $\begin{array}{l}.000 \\
.000\end{array}$ & & $\begin{array}{l}0.000 \\
.000\end{array}$ & 02.000 & $\begin{array}{l}\text { S. UUu } \\
\text {.UUu }\end{array}$ & $\begin{array}{l}\text { - vuu } \\
\text {. vuo }\end{array}$ \\
\hline & $\begin{array}{l}.040 \\
2.533\end{array}$ & & $\begin{array}{l}3502.000 \\
8567.755\end{array}$ & $\begin{array}{r}15592.000 \\
8567.755\end{array}$ & $\begin{array}{l}.000 \\
3.533\end{array}$ & $\begin{array}{l}41 \\
10\end{array}$ & $\begin{array}{l}5.004 \\
3.533\end{array}$ & \\
\hline & & 1.7075 & .6437 .000 & $4<024 \cdot 000$ & & & $4 \cdot 000$ & b.uuv \\
\hline 92 & & $\begin{array}{r}206264.172 \\
133950.699 \\
92205.069\end{array}$ & $\begin{array}{l}202462.422 \\
135362.944 \\
93830.460\end{array}$ & $\begin{array}{l}210653.395 \\
116815.189 \\
104381.792\end{array}$ & $\begin{array}{l}2819.264 \\
0819.655 \\
4361.742\end{array}$ & $\begin{array}{l}242535.117 \\
151668.123 \\
104381.792\end{array}$ & $\begin{array}{l}236105.145 \\
146109.590 \\
104381.142\end{array}$ & $\begin{array}{l}2313780012 \\
1356,9.502 \\
105326.222\end{array}$ \\
\hline
\end{tabular}

$$
1992
$$

1993

1994

1995

$1946^{\prime}$

IUIAL

AVEKAGE

$18633.000 \quad 19526.000 \quad 80458.000 \quad 21418.000 \quad 2244600002667790000 \quad 13348.450$

$10847.5615 \quad 73838233 \quad 8646.039 \quad 7608.846 \quad 6521.052181646 .464 \quad 4544.623$

$79647.130 \quad 72041.262 \quad 13534.200 \quad 15017.577 \quad 16809.458902486000940149 .330$

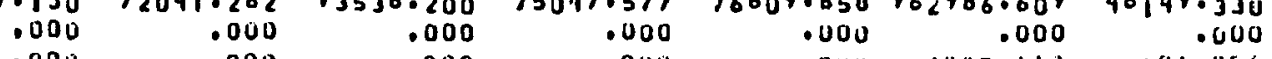

$.000 \quad .000 \quad 000 \quad 000 \quad .0003839 .113 \quad 191.956$

.000 .00000048618 .00011648 .505

. $\quad .000 \quad 000000430.400$ 4115.133

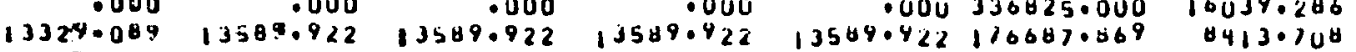
$336825.000530 .925 .0003 \$ 6825.000336825 .000336825 .000581 / 013.000271060 .613$

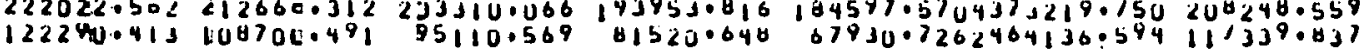
$105320.2221058650586136643 .526 \quad 107821.55410910008902031541 .516$ 41001.477 
SYSTEMS, SCIENCE AND SOFTWARE

LAC PROJECTION HOOEL

PIPELINE. TRANSPORTATION SYSTEMS ENERGY CONSERVATION STUDY

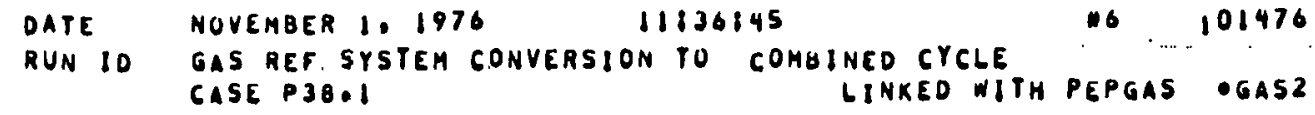

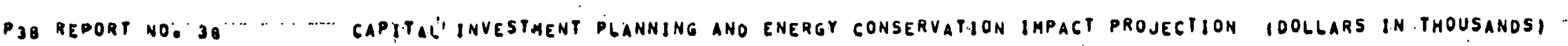
TIAE PERIOD
1976
1977 .
1978.1979
1980
1981
1982
1983

ictivity

ANAUAL THROUGHPUT (MHAHCFOHILESI

NOHINAL TARIFY IUHIT TRANSP. CHARGEI

.000

ACTUAL TARIFE

NOHINAL TRANSDORTATION REVENUES

.000

ACTUAL TOTAL REVENUES

.000

.000

57.758

660.000

632.265

$61 \cdot 326$

693.000

42499.196

$64 \cdot 945$

727.650

$592 \cdot 348$

68.556

$704 \cdot 032$

566.912

EVERAGE

LONGETEQM (EUNOED) DEOT TO CAPITAL:

61.4114

$61.414 \quad 6 j .414$

47256.953
38469.797

$52379 \cdot 136$

- $72 \cdot 228$

602.234

566.747

38096.598

57943.542

75.742
842.346 842.346
544.076

$63801 \cdot 068$

44996.602

79.476

884.463

6220147

$70293 \cdot 402$

LONG-TERM IFUNOEDI OEBT TO ASSETS

60.000

59.547

59.101

60.051
57.269

58.588

$62 \cdot 154$

62.839

$65 \cdot 716$

PROFITA3ILITY

OPERATING INCONE (EPC RULES)

ANIUAL FPC RATE BASE

$20945.772 \quad 20375.466 \quad 19785.703$

RATE OF RETURN ON PATE BASE 181

RATE OF RETURN. ON PAIO-IN CAPITALISI

212374.00

RATE OF RETURN ON TOTAL CAPITAL' ISI

4.000209457 .723203025 .168

9785.703
7792.061319

19205.913 .19948 .070

.000

$\begin{array}{ll}10.000 & 10.006 \\ 11.201 & 10.560\end{array}$

10.003

9,960005

$21226 \cdot 235$ .000.

. 4.586

4.323

4.195

10.005
90910
4.354

94356.000

22444.591

NERGY CONGUMPIION

ANTUAL ENEREY USAGE OF GAS (AHCE)

ANNUAL ENEREY COSTS

PRESENT VALUE OF EMERGY USEO

1273,605

1471.607

1647.000

4.354

10.006

10.006
11.135

$24293 \cdot 070$

$4.583 \quad 4.390$

10.007
12.139

$4 \cdot 416$

UNIT. COST OF ENERGY BRHCF

.000
.000

1808.803

2194.165

1833,321

2066.802

2808,138

3013.664

3567.340

$\begin{array}{rr}3.360 & 1937.236 \\ 1.491 & 1.566\end{array}$

058.373

$2215 \cdot 037$

5089.247
2872.747

3415.385

1.644

1.726

1.812

6499.258

$3335 \cdot 147$

.1 .903

OTHER MEASURES

TOTAL ANNUAL" INAT COSTS

PRESENT VILUE OF ALERAGE UNIT COSTS

NET INCOME: IBOOK PHOFITI

417.241

430.720

409.028

$393 \cdot 402$

377.798

416.527 268.699

8804.014

234.583

9381.287

307.309
8791.525

PRESENT VALUE OF BOOK PROFITS

.5113 .000

9951.593

$7753: 130$

6791.525
6605.203

6013.260 10138.451

2350118

9892.336

92420962

9255.452

6295.180

5533.966

$10589.889 \quad 11312.528$

$17806.531 \quad 17236.225$

6944.374

.683

.621

.564

$436 \cdot 002$

2230138

10784.572

$5534 \cdot 191$

128860026

6612.569

- 513

1.000

.826

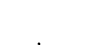


SYSTEMS. SG!ENCE AND SOFTHARE

LAE PROJECTION MODEL

PIPELINE IRANSPORTATION SYS-EMS

ENERGY CONSERVATION STUOY

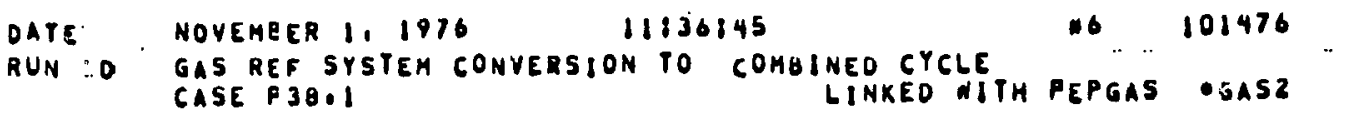

Pa REPORt no. Jo

CAPITAL INJESTMENT P:ANMING ANO EMERGY CONSERVATION IMPACT PROJECTION IDOLLARS IN THOUSANDSI

TIME: PERIOO

ACTIVITY

ANNUAL THROUGHPUY (MAMHEFOMILESI MOMINAL TARITE IUAIT TRANSP, CMARGEI

ACTUAL TARIFE

NOMINAL TRANSOORIGTION REVENUES

actuAL TOTAL: REVENUES

LEVERAGE

LONG-TEQM IFUNOED OEBT TO CAPITAL:

LONGOTEAM IFUMDEO. OEBT TO ASEETS

PROTITABILITY

OPERATING INCOME IEPC RULES I

ANNUAL SPC RATE BISE

PNTE OS RETURM ON RATE QASE

G RATE OF RETURN ON PAIO-IN CAPITALIEF
TN RATE OF RETURN ON TOTAL CAPITAC IOI

EnERGR consugPtion

ANNUAL ENERGY USAGE OP GAS (MMEF)

ANNUAL ENERGY COSTS

PRESENT VALUE OF CNERGY USEO

UNJT COST OF ENERGY SIMHCF.

OTHER MEASURES

TOTAL ANNUAL UNIT COSTS

PRESENT VALUE OF WVRAGE UNIT COSTS

NET INCOME' IBOOK PROEITI

PRESENT VILUE OF GOOK PROFITS

NET CAST GENERATE DURING THE DERIJO

PRESENT VALUE OF AET CASH GENERATED

OISCOUNT FACTOR (DIO.000

\section{4

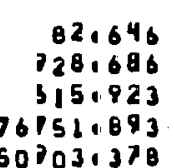

$1 \cdot 85$

1986

1987.

86,152
$75 \cdot 121$
-27.790
8400.302

4008.302

$54085 \cdot 259$

64.433
59.184

$64 \cdot 6.9$
50.777

62.953
56.261

23326109

$230196.7 E$

22024

$10.0 \mathrm{C}$

11.08

4.187

8151.551

10.004

11.603
4.312

22610.531

25951.561

10.007

10.007
11.275

4.432

23588.783

580783

10.003
13.788

1.745
4.788

1908

1989

1996

1991

$3.359+445$

$6113+024$

2351.771

$3943.5 \geq 7$.

$8063.6+9$

3119.733

4166.690

9176.743

3538.803

$4719 \cdot 3.99$

$: 09160113$

3826.031

2.313

13259.200

4224.793

2.429

747.148
208.598

$160 \cdot 6.33$

195.314

9353.478

4596.750

1.1999 .045

5597.643 4394.512

1117.970

4769.534

1967
485.955

179.953

10017.148

3862.044

10434.646

4023.008

.386

\section{$461 \cdot 138$}

161.626

12249.419

42930347

12495.372

4379.552

\section{$515 \cdot 57 !$}

164.277

10995.501

4150.408
13025.758

.319

101.105
185.265

1185.265
734.920

105.183

1244.528

736.448

1188360758130903.530141999 .631

74304.45076836 .92079790 .262

\section{(2)}

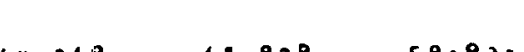

55.438 .

$58 \cdot 921$ 48.178 .550

$24372 \cdot 47723456 \cdot 953 \cdot 22540 \cdot 462$ $243502.22923437 \% .4512252520674$ $\begin{array}{rr}23437 \% 451 & 2252520674 \\ 15.006 & 100007\end{array}$ $\begin{array}{rr}16.006 & 10.007 \\ 10.401 & 120636\end{array}$ $4.964 \quad 5.366$

$4.686 \quad 4.964$

6024.902 15364.196 4450.461

2.550

6707.010

$7403 \cdot 606$ 2960.97520815 .264 $4729.686 \cdots 4963.009$ $\begin{array}{rr}4.678 & 2.812\end{array}$

532.884
154.386
11011.863
3189.745
12722.133
3685.149
.290

532.205 141.463 $1101 \% .694$ 2901.303 10041.067 $264 \% .127$

.263

$543 \cdot 384$ 130.082 11226.234 2687.473 9985.159 2390.368

.239
61.839

108.666

$1306 \cdot 755$

$734 \cdot 272$

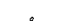


SYSTEAS, SCIENCE: AND SOFTHARE

LAC PROJECTION HODEL

PIPELINE TAANSPORTATION SYSTEMS

ENERGY CONSERVATION STUOY

DATE NOVEMBER 1. 1976 11:36:45

RUN 10 GAS REF SYSTEM CONVERSION TO COMGINED CYCLE CASE PJB.I

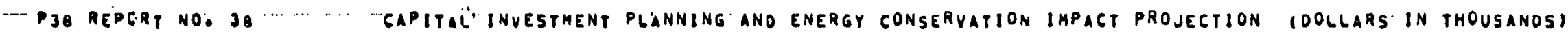

\section{TIAE: PERIOD}

ACTIVITI

ANNUAL PHROUGHPUT IMHAHCFOHILES

NOMINAL TAAIFE IUNIT TRANSP. CHARGE

ACTUAL: TARTEF

NOHIAAL TRANSDORTATION REVENUES

ACTUIL TOTAL REVENUES

ENU

CEVERAGE

LONG-TEQA ITUNOEDI OEOT TO CAPITAL:

LONGATERA (FUNOEDI OEBT TO ASSETS

1992

1993

1994

1995

1996

TOTAL

100.666

1372.092

$745 \cdot 165$

149099.611
809730998

108.666

1440.697

756.916

108.666

1512.732

769.585

56554.592

64382.318

108.666

108.666
1588.368

783.747

$108.666 \quad 1787.723$

$\begin{array}{rr}1080666 & 1787.723 \\ 1607.787 & 21823.527\end{array}$ $\begin{array}{rr}1667.787 & 21823.527 \\ 748.368 & 13028.370\end{array}$

$\begin{array}{rrr}1667.787 & 21823.527 & 10911176 \\ 748.368 & 13028.370 & 651.418 \\ 81231.5042051965 .406 & 102598.270\end{array}$ 72601.434

$\begin{array}{rrrrr}164382.318 & 172601.434 & 181231.50420519650406 & 102598.270 \\ 83627.570 & 85166.531 & 86755.3831224997 .453 & 61249.873\end{array}$

55.556

51.673

47.181

41.956

35.809

590894

PROFITAQILITY

OPERATING INCOME (FPC RULES)

ANNUAL FPC RATE BASE

RATE OF RETURN ON RATE OASE IEI

RATE OF RETURN ON PAIOEIN CAPITALIISI

44.706

36.052

$31 \cdot 142$

25.788

52.083

59.894

21629.43120718 .462

19807.560

RATE OF RETURN ON TOTAL. CAPITAUI ISI

21612700962070030119

17974.4144310210375

$10.008 \quad 10.009$

$12.870 \quad 13.105$

6.313

8.342

13.339

88753.564

$17974 \cdot 414431021 \cdot 375$
$79628,7874520022 \cdot 625$

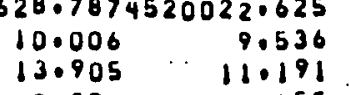

10.006

13.672
7.569

8.308

4.055

ENERGY CONSUMPTION

ANYUAL ENERGY USAGE OR GAS IMMCRI

ANNULL ENERGY COSTS

PRESENT VALUE. OF ENERGY USEO

OISCOUNTEO VALUE OS ENERGY USED

UNIT COST OF ENEAGY SIMMCE

$7403.608 \quad 7403.608$

$21856.027 \quad 22948.828$

$1756.509 \quad 4540.304$
1100

7403.608

7403.608
25301.083

4540.304
617.154

24096.270

4333.926

4136.930

7403.60892918 .903 26566.137247190 .464

3948.88769617 .154

3.255

3.417

3.588

46.954

$567.200 \quad 675.929$

575.929
94.169

586.732

9682.974

TOTAL ANNUAL UNIT COSTS

$550.449, \quad 558.370$

102.017

07.214

3854,762

482073

OISCOUNTED AVERAGE IANNJALII UNIT COSTS (LONGARUN AVERAGE COSTSI 12 10.00.1. NET INCOME: IBOOK PROF IT

192.738

PRESLNT VALUE OF BOOK PROFITS

$\begin{array}{rr}11434.243 & 11642.310 \\ 2488.425 & 2303.369\end{array}$

OISCOUNTEO NAIUE OF HOOK PROFITS 12 10.00.

PAESLNT ValUE OF NET GASH GENERATED

OISCOUNTED NES CASH FLON. 10 10.00 \&1.

905207

81892.937

2166.0099942 .264

1850.443
2131.407

$12 ! 46 \cdot 118$

12353.535208790 .789

$1836.274 \quad 81892.437$

4094.647

$9951.711 \quad 10034.305 \cdot 10130.740230762 .527$

1505.870104181 .533

10968.692

1789,903

1640.689

5209.077

$.180 \quad .164 \ldots .149 \quad .000 .000$

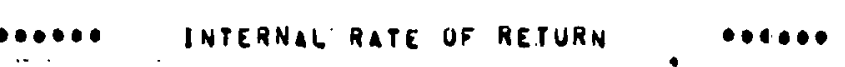

$.218 \quad .19$

JCF - ROI OF \$ 88841.999 IFROA YEAR I OYER IO YEARSI * 6.8O

JC5 AOI OF \$ 88841.999 IFROM YEAR I OYER I5 YEARSI 11.31

JCE ROI OE \$ BO841.849 IFROM YEAR I OUER 20 YEARSI. 12.70 


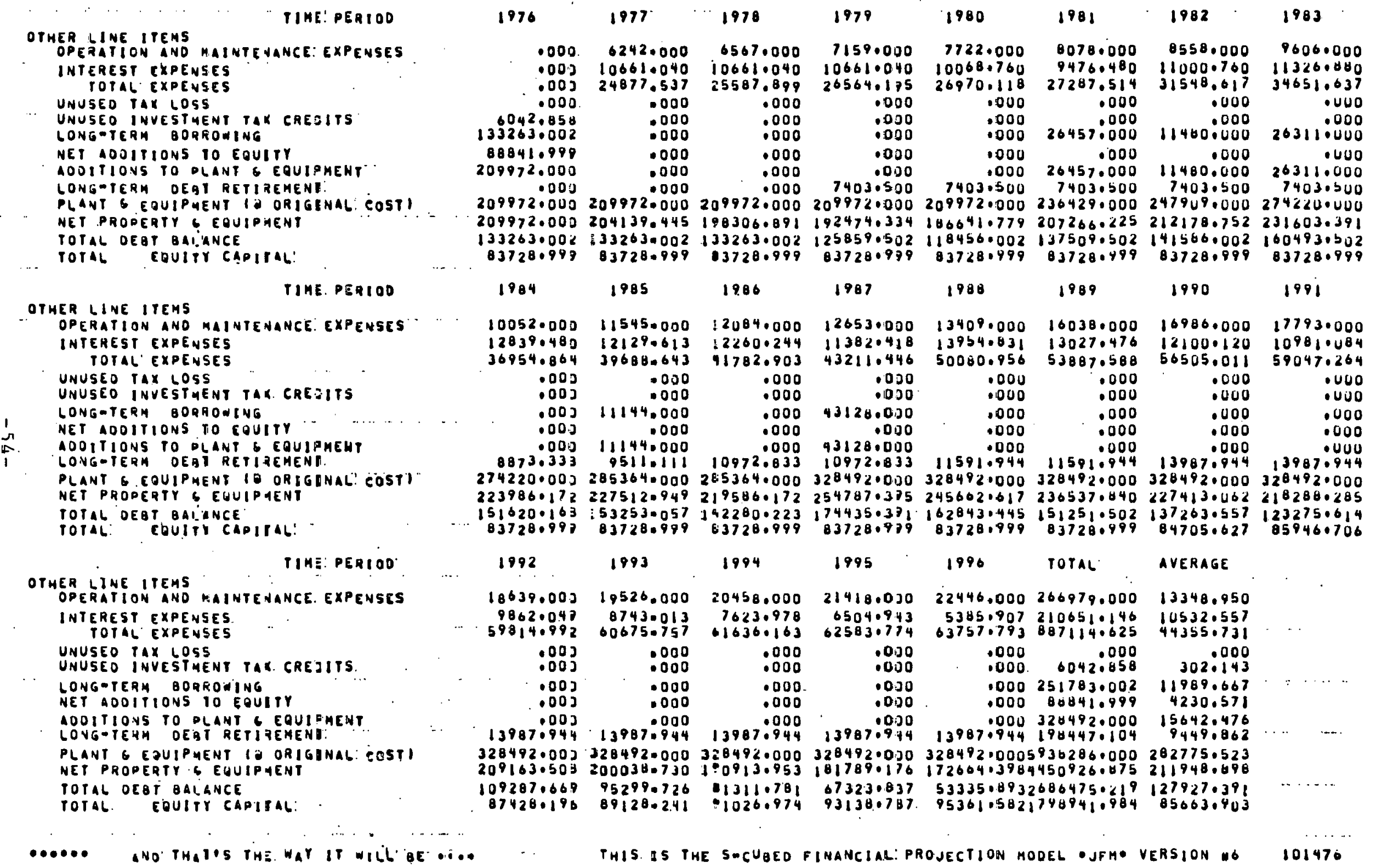


Table $4 \cdot 1 \cdot 1 \cdot 3-4$

IIJPUTS AND ASSTMPTIONS

1. Full-load efficiency advantage of the combined cycle over the simple cycle is one-third.

2. Full-load efficiency advantage of the regenerative cycle over the simple cycle is $18 \%$.

3. Present values calculated at $10 \%$.

4. All profits paid in dividends.

5. All excess working capital reinvested at $6 \%$.

6. Straight-line depreciation on first three capital outlays.

7. Market growth as shown in line 1 of the figures.

8. Base year 1975, inflated as shown in Fig. 4.1.1.3-3 
Table $4 \cdot 1 \cdot 1 \cdot 3-5$

COMPARISON OF ENGINE CYCLES

\begin{tabular}{|c|c|c|}
\hline & Simple & Comb'd. \\
\hline Energy use, avg , BSCF/yr & 6.46 & 4.65 \\
\hline Efficiency improvement, avg., $\frac{\mathrm{o}}{6}$ & 0 & 28.02 \\
\hline Energy cost, avg., M $\$ / y r$ & 17.28 & 12.36 \\
\hline $\begin{array}{l}\text { Present value of energy used, } \\
\quad \text { M\$( } 20 \text { years) }\end{array}$ & 96.43 & 69.62 \\
\hline $\begin{array}{l}\text { Actual tariff, avg., } \\
\text { K\$/GSCF-Mi. }\end{array}$ & 707 & 651 \\
\hline Tarztt reduction, 옹 & 0 & 7.92 \\
\hline $\begin{array}{l}\text { Present value of book profit, } \\
\text { MS }\end{array}$ & 87.24 & 81.89 \\
\hline 10-yr ROI-DCF, $\%$ & 6.89 & 6.80 \\
\hline $20-y r \quad " \quad "$ & 12.14 & 12.70 \\
\hline $\begin{array}{l}\text { Unused investment tax credits, } \\
\text { MS }\end{array}$ & 3.84 & 6.04 \\
\hline
\end{tabular}


Several points of interst are evident. First, from lines 1 through 4, it is seen that the energy saving actually realized for the assumed duty cycle (which is determined by the assumed market growth and the power increments necessary to meet it), though reduced somewhat from the full-load values, is still very large. Second, from the viewpoint of economy, the 20-year present value of energy saved would be $\$ 26.8 \mathrm{million}$ for the combined cycle. In terms of prime mover capacity, this latter figure represents $\$ 654$ per horsepower for the particular set of assumptions used, which is almost twice the average 1975 cost of gas turbines in pipeline service. The above dollars per horsepower figure is based on a total horesepower requirement of 147,507 (see Table 4.1.1.3-2) and is derived as follows:

$\frac{\$(96.43-68.62) 10^{6}}{\$(96.43) 10^{6}} \times 147,507 \mathrm{hp}=41,011 \mathrm{hp}$

attributable to bottoming cycle

$$
\frac{\$(96.43-69.62) 10^{6}}{41.011 \mathrm{hp}}=\$ 654 / \mathrm{hp} \text {. }
$$

Bottoming engines, because of their requirements for boilers and condensers, are almost certain to be more expensive than open-cycle gas turhines, but not by a factor of two. It is therefore concluded that the bottoming engine offers to the DOE a highly attrative opportunity for pipeline energy conservation.

Third, from the point of view of the consumer, the tariff reduction is approximately $8 \%$ with the improved engines. And fourth, from the point of view of the pipeline operator, lines 7-10 offer little indueement to invest in energy-conservative devices. Book profits actually fall slightly. For practical purposes, RoI is the same for all three cases, the small variations being primarily due to differences in timing of the capital infusions. 
Unused investment credits increase strongly for the energyconservative cases, as explained in another report of this series, HCP/M-117l-3, Section 7.0 (see pp. I and 2 of this report). Basically, they derive from the limit upon profit imposed by FPC regulation. Clearly, some change in that regulation is needed to induce pipeline operators to conserve energy.

One regulatory change that seems reasonable would in effect divide the advantage between the consumer and the pipeline operator. This could be accomplished by allowing the operator to retain, in addition to the standard regulated return, a portion, e.g. , one half, of the additional profit generated by the energy-conservative. innovation. For purposes of policy promulgation, the allowance for additional profit should be related to the quantity of enerqy saved. However, other regulatory changes appear more effective (see HCH/M-1171-3 of this series).

4.1.1.4 Combined System Performance

Both the organic fluid Rankine cycle and the steam Rankine cycle were seen to offer high potential for waste heat recovery. Projected efficiencies for the gas turbine combined cycle are shown in Fig. 4.1.1.4-1.

For a typical first generation gas turbine with a thermodynamic efficiency of approximately 20 o (heat rate of $12725 \mathrm{Btu} /$ HP-HR), the addition of an organic Rankine cycle can increase the over-all system efficiency to 31\%, while a steam bottoming system with $150^{\circ} \mathrm{F}$ condensing temperature will increase the over-a.l. combined efficiency to 27\%. (These figures are calculated for different site conditions and condensing temperatures than in the examples in section 4.1.1.3. Thus, lower efficiencies are calculated in this case.) However, this turbine can also be improved by adding a recuperator. In fact, efficiency improvement with a recuperator is equal to the improvement with an organic Rankine cycle and better than a steam Rankine cycle. Because of this it is unlikely that the bottoming engine would be cost-effective. This 


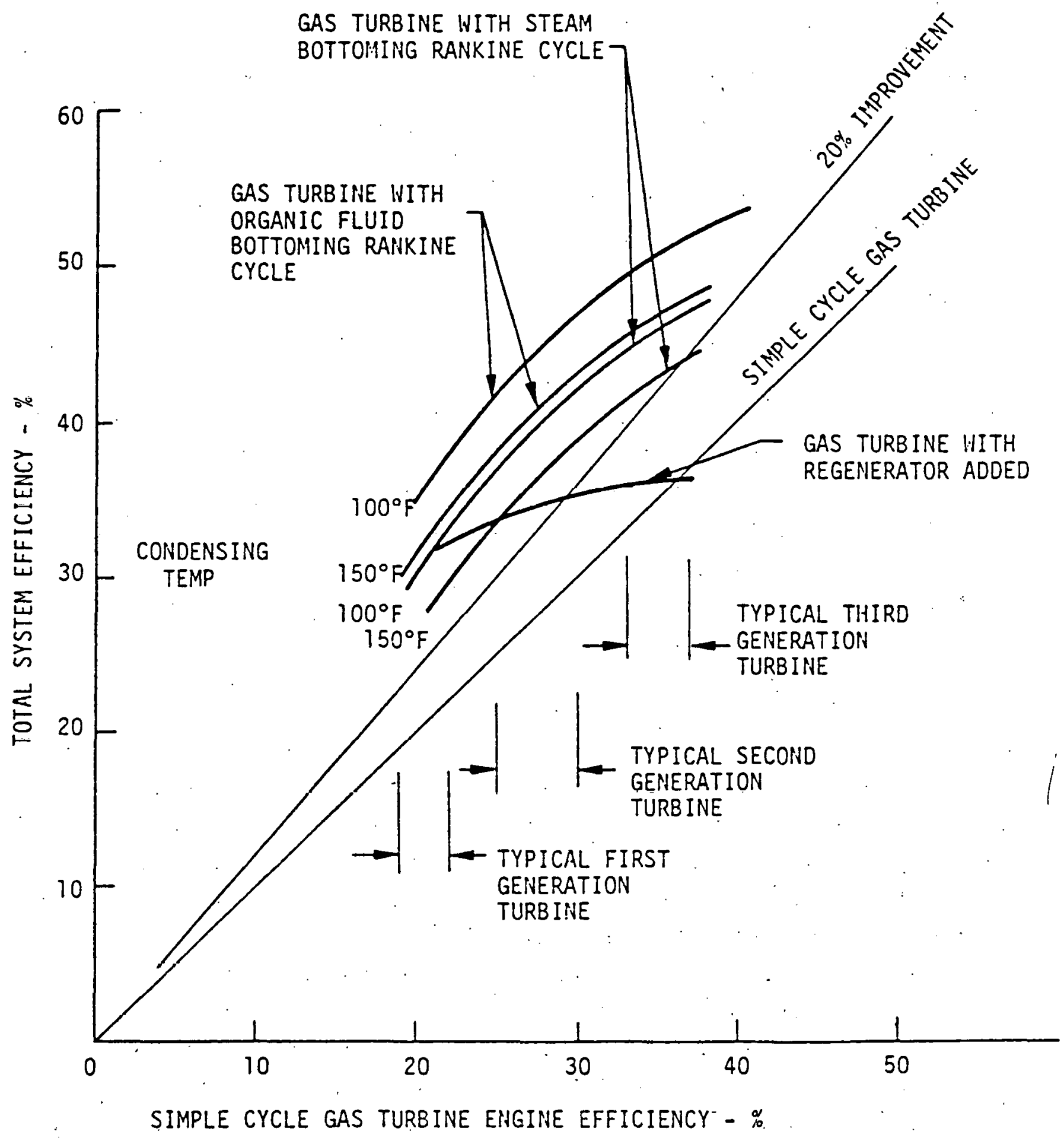

Fig. 4.1.1.4-1 Combined System Efficiency with Gas Turbine 
conclusion bears repeating for emphasis. The bottoming engine, inherently, does not appear to be a viable candidate for retrofit on the first-generation turbine.

For a second generation gas turbine, representative of those installed on pipelines, the typical thermodynamic efficiency is 27\%. The organic Rankine bottoming system, which offers much more than a $20 \%$ improvement over the simple cycle engine, appears to be cost effective, and can be applied as retrofit to the second generation gas turbine installations.

For a third generation gas turbine with a typical efficiency of 35\%, recuperation is not possible because there is not enough positive temperature differential between the power turbine exhaust gas temperature and the compressor discharge gas temperature. The steam Rankine bottoming system barely offers a $20 \%$ improvement but the organic Rankine bottoming system offers a combined efficiency of $47 \%$, a $34 \%$ improvement over the open engine.

In summary, for gas turbine engines of the future, the organic Rankine bottoming system will offer far better than $20 \%$ improvement over the open engine, while the steam system will offer less than $20 \%$ improvement. In terms of product obsolescence, the organic system is much to be preferred.

The reason for this very significant conclusion lies in the upward trend of turbine inlet temperatures through the years. As inlet temperatures have $r$ isen, so have exhaust temperatures, so that the heat available to the bottoming engine increases signiticantly with each new generation of turbine. Along with these higher temperatures, pressure ratios increase, so that regeneration become less attractive, and finally impractical.

The situation with the gas reciprocators is discussed in Section 4.1.3 below, where it is shown that approximately 20\% improvement can be realized by adaing the organic Rankine even to the most efficient engines. This conclusion is opposite to that which was reached relative to the turbines. To repeat for emphasis, the older (first generation) turbines are not viable candidates for 
bottoming engine retrofit, whereas with the reciprocators the opposite is true, i.e., the older machines are indeed attractive retrofit candidates. Some further implications will be examined in Section $4 \cdot 1 \cdot 3$.

\subsubsection{Diesel Engine Improvements}

The diesel engine has achieved an advanced state of development and has gained increasing acceptance in heavy duty vehicular as well as industrial applications in recent years. Today's modern, high output diesel engine approaches $40 \%$ brake thermal efficiency over a broad range of speeds and loads. While there is some potential for further improvement in efficiency through the use of high pressure ratio turbocharging and design refinements such as borestroke ratio, reduce friction, and improved combustion, such gains will probably be marginal. For achievement of significant gains in fuel economy, more basic changes are necessary. Foremost among these are combined cycle systems employing either the Brayton cycle or the Rankine cycle to recover part of the exhaust energy of the diesel cycle.

\subsubsection{Diesel-Brayton Combined Cycles}

This type of power plant in its usual form is known as a turbo-compound engine consisting of a diesel engine and a gas turbine whose outputs are connected together through gearing into a common output shaft.

Considerable work on turbo-compounding was carried out in the 1945-55 period, mainly in the aircraft t'ield where the main benefits were realized in altitude performance. The curtiss-Wright engine used in the DC-7 aircraft is a well known example of a 4-cycle spark ignition turbo-compund engine. The Napier Nomad turbo-compound engine (Ref. 10) developed during the same period, represented a very significant achievement as a high output, lightweight diesel engine for aircraft use. The Napier engine, shown in Fig. 4.1.2.1-1, consisted of a 2-stroke diesel engine and an axial flow compressor coupled together to form a common system: the 12-stage axial compressor provided a pressure ratio of $8.25: 1$ at maximum speed at an efficiency of 75-77.5\%. The engine produced 
3135 net hp with a special fuel consumption of $0.345 .1 \mathrm{~b} / \mathrm{hp} / \mathrm{hr}$ and had only small variation in sfe with load. The engine was never put into production, primarily because its development came at a time when jet aircraft were superseding the propeller craft. A more recent concept in turbo-compound engines is the Johnston engine (Ref. 11) now undergoing development at Engine Systems, Inc., under contract to the Army Tank-Automotive Command. The engine, illustrated schematically in Fig. 4.1.2.1-2, consists of four basic subsystems: (1) a high-pressure ratio turbocharger, (2) an uncooled piston, (3) internal cooling of the cylinder liner and valve passages (details not shown in the figure), and (4) a separate exhaust turbine connected by, reduction gearing to the engine crankshaft. The most unusual feature of the engine is the fact that the piston and cylinder are not cooled by conventional means. The engine utilizes a uniflow, two-stroke arrangement with excess airflow during the valve open position of the stroke, and the piston and cylinder are internally cooled by the excess scavenging air. The cooling medium is the working fluid, so that all the unavailable energy is contained in the exhaust and can be recovered in an exhaust turbine. The design by Engine Systems is based on a 4:1 pressure ratio and $83 \%$ efficiency in both the turbocharger turbine and exhaust power turbine. Matching the turbo unit to the engine for off-design conditions is planned to be accomplished by use of variable area nozzles in the power turbine.

The potential performance improvement of the Johnston engine over typical commercial diesel engines is shown in Fig. 4.1.2.1-3. The curve of specific fuel consumption vs. horesepower was computed as part of a study for the Army Tank-Automotive Command. The data indicate a potential reduction of 25 to $30 \%$ in fuel consumption along with an increase in horsepower of $100 \%$ for the Johnston engine over commercial engines of the same displacement, speed, and fuel/air ratio (Ref. 12). 


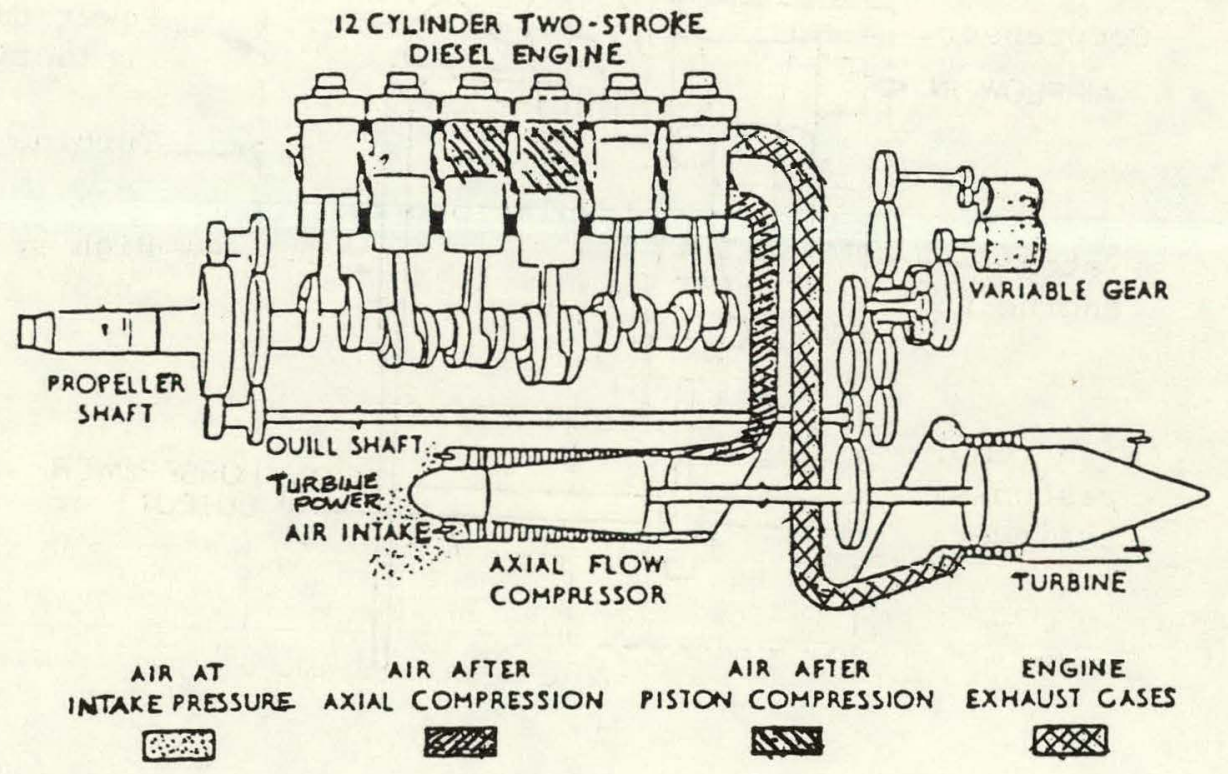

Fig. 4.1.2.1-1 Napier nomad turbocompound diesel engine - schematic arrangement

Source: Reference 10 


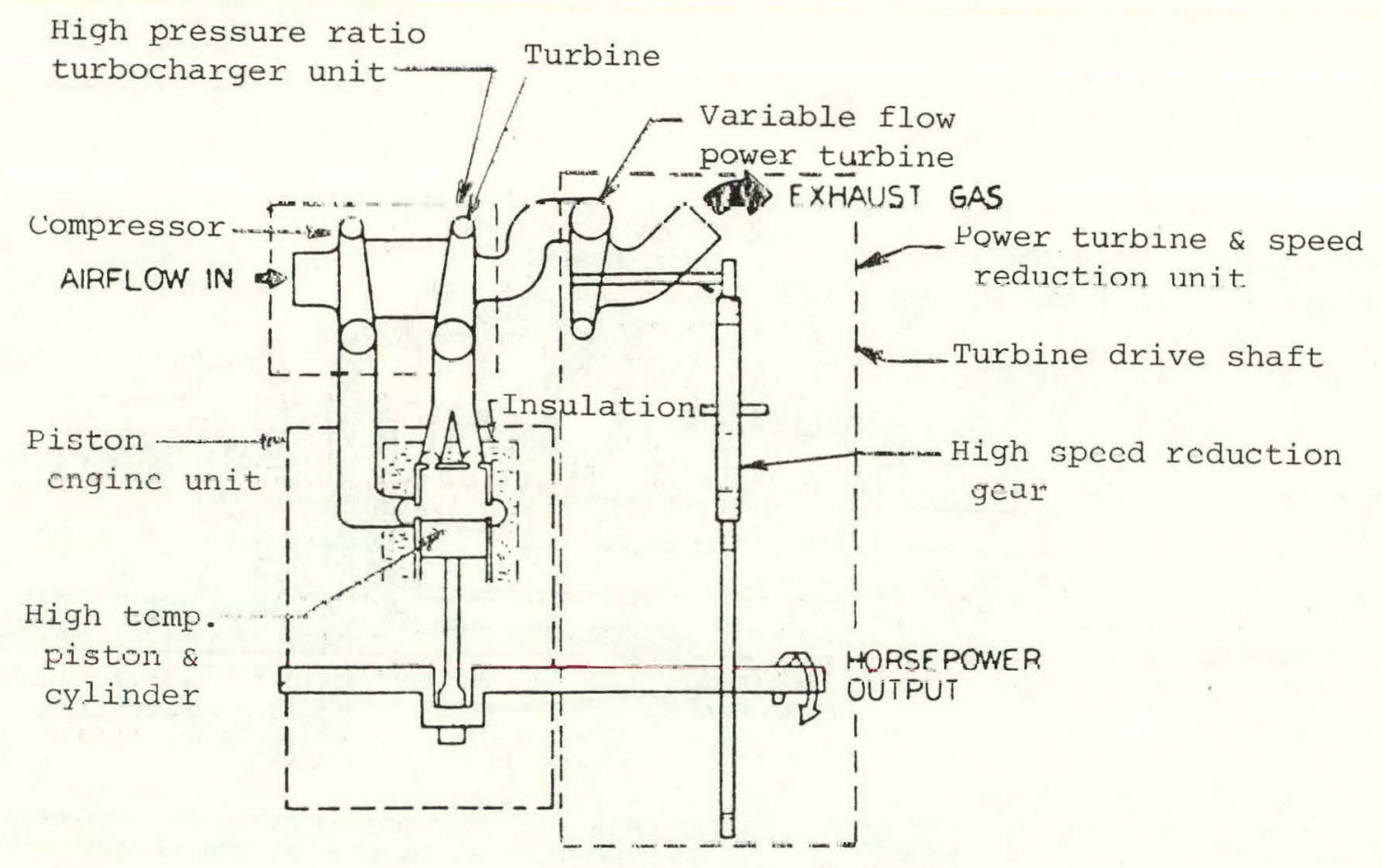

Fig. 4.1.2.1-2 Johnston engine schematic

Source: Referencc 11 


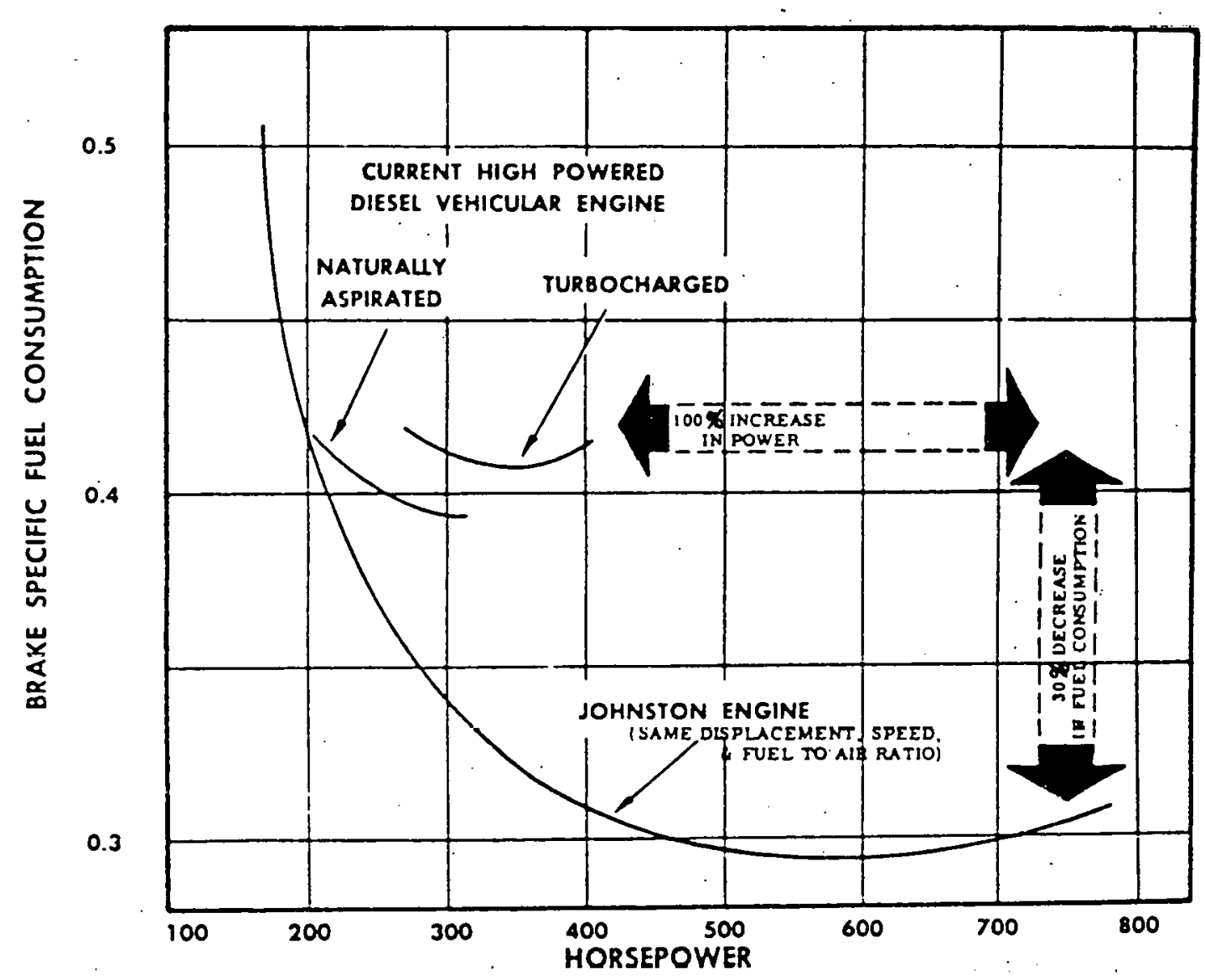

Fig. 4.1.2.1-3 Johnston engine performance

Source: Reference 12 
The key to performance in the Johnston engine lies in the method of cooling the piston and cylinder. Cooling is not accomplished in the conventional manner of rejécting heat to a separate cooling medium, either liquid or air. Conventional engines lose approximately $30 \%$ of their heat energy by this route. Instead, the piston-cylinder configuration is designed as shown in Fig. 4.1.2.1-4, with an elongated piston in a uniflow scavenged, two-stroke arrangement, which keeps the piston rings on the bottom of the piston, away from the area of high metal temperatures. The cylinder is internally cooled with excess scavenge air and the cylinder head and valves by air flow which enters the exhaust stream, so that most of the cooling energy is recovered in the exhaust turbine. The primary engine parts must be manufactured from high temperatures allowys to enable the engine to run at much higher temperatures (800-13000F) than heretofore used in conventional engines. Engine Systems, Inc., under contract with the U.S. Army Tank-Automotive Command, has designed and built a single-cylinder research engine around this concept and conducted limited tests which demonstrated the feasibility of the design, including the fact that the engine components could operatesatisfactorily at elevated (1500\%) metal temperatures (Ref. 12). In a subsequënt contract, heat transfer and stress analyses were performed for each of the major components, i.e.; the cylinder head, exhaust valve, piston, and cylinder liner. (Ref. 13). A study was also made of a General Motors 6V71 diesel engine, modif'ied to the Johnston engine concept, as a potential candidate for the Army XM-723 vehicle. The study indicated a specific fuel consumption of $0.297 \frac{\mathrm{lb}}{\mathrm{hp}}-\mathrm{hr}$, representing a reduction of $27-45 \%$ as compared with present commercial, high-output diesel engines used in this vehicle. l'he study also showed that the engine would offer an appreciable weight reduction and would fit into a slightly smaller envelope than the existing commercial engines in the XM-723 velicle. Further development awaits availability of funds. 
The methods by which the Johnston engine accomplishes internal cooling are particularly adaptable to two-stroke engines. Another development program, supported jointly by the Cummins Engine Co. and the Army Tank-Automotive Command, șeeks to accomplish the same basic objective of internal cooling of a four-stroke engine. The basic approach, which is to insulate the cylinder and use ceramic hot parts, is described in a paper by Kamo (Ref. 14). Cummins is hopeful that basic feasibility of a 0.28 BSFC will be demonstrated in 1978 .

It is important to emphasize the fundamental distinction between the type of turbocompounding that is represented by the curtiss-Wright and Napier engines on the one hand, and by the Johnston and Cummins engines on the other. That distinction lies in the fact that these latter engines are cooled internally by air, which then enters the exhaust stream. Thus, the approximately $30 \%$ of input energy that is ordinarily lost in the cooling jacket is available kto the bottoming engine. While both types of engine are turbocompouunded, it is the internal cooling of the Johnston and Cummins engines that gives them their high potential for improved performance. The importance of internal cooling, and the opportunity that is offers, are further discussed, in Sectin 4.1.3, where its exploitation in the pipeline industry is recommended.

\subsubsection{Diesel-Rankine Combined Cycles}

Recent development effort on power plants utilizing diesel engines combined with Rankine bottoming cycles has been prompted by rising fuel costs and the increasing emphasis on energy conservation. Earlier work on automotive Rankine cycle systems which was directed toward reducing air pollution has provided much of the technology for the diesel-Rankine cycle power plant. A number of industrial firms, including Aerojet-General Corp., Thermo electron Corp., Sundstrand Aviation, Steam Engine Systems, Lear Motors Corp., Steam Power Systems, and Brobeck \& Associates, have built and demonstrated Rankine cycle power plants in passenger cars on 
buses under sponsorship of federal or state government agencies. others, notably General Motors Research Laboratories and Ford Motor Co., have developed experimental Rankine cycle systems for vehicles, either as in-house projects or utilizing subcontractors. While the majority of these systems have been steam powered, three of the companies (Aeroject, Thermo Electron, and Sundstrand) have used organic working fluids. Extensive investigations, supported by NASA, the DOE, and DOD agencies, have also been conducted in recent years on small organic Rankine cycle units for space applications and ground electric power. Studies to determine critical parameters for organic working fiuids have been made by these and other organizations. 'These programs have likewise provided usef'ul technology for current efforts on organic Rankine bottoming cycle systems.

Selection of the working fluid for a Rankine cycle system often proves to be an extremely complex process, since it involves several major considerations, such as: thermodynamic characteristics, thermal decomposition, compatibility with materials used in structural components, safety characteristics (flammability, toxicity, etc.) freezing temperature, and cost. Water has the advantage of being inexpensive, plentiful, chemically stable to high temperatures, and having well defined thermodynamic properties. However, it is not a good working fluid for low-temperature applications because its high latent heat of vaporization makes it necessary to employ low boiling pressures; therefore, cycle efficiency is low.

The general nature of this inferiority of water to other fluids may be seen by referring to Figs. 4.1.2.2-1 - 4.1.2.2-3. The first of these merely displays the Carnot equivalent cycle on the temperature-entropy plot for later comparison. The second figure shows the saturation line for water and a typical steam cycle. Because of the negative slope of the vapor side of the dome, to expand to a point. A with acceptable moiture content in the steam, it is necessary to superheat to point $B$, much higher in temperature 


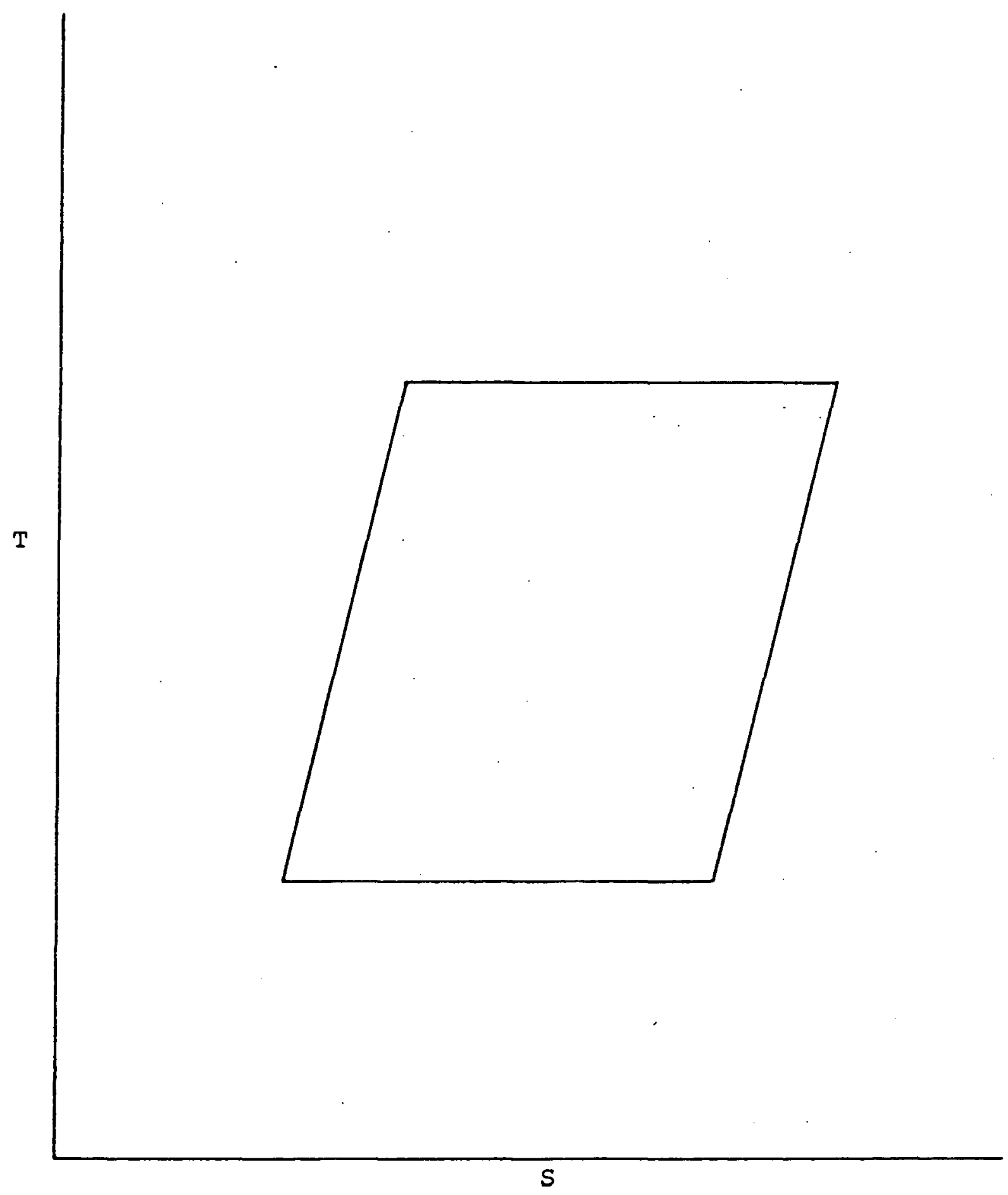

Fig. 4.1.2.2-1 Carnot-equivalent cycle 


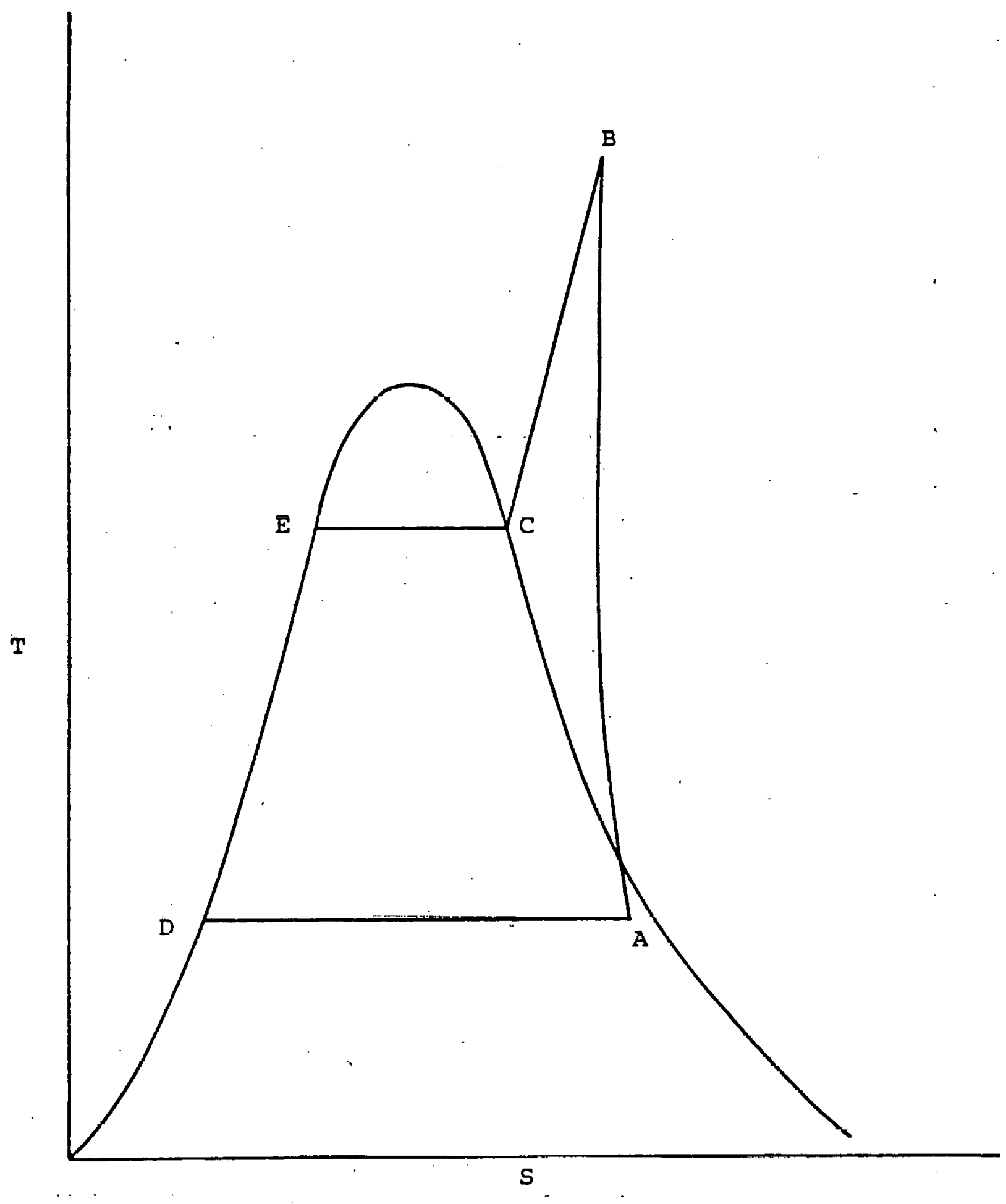

Fig. 4.1.2.2-2 Saturation line for water 


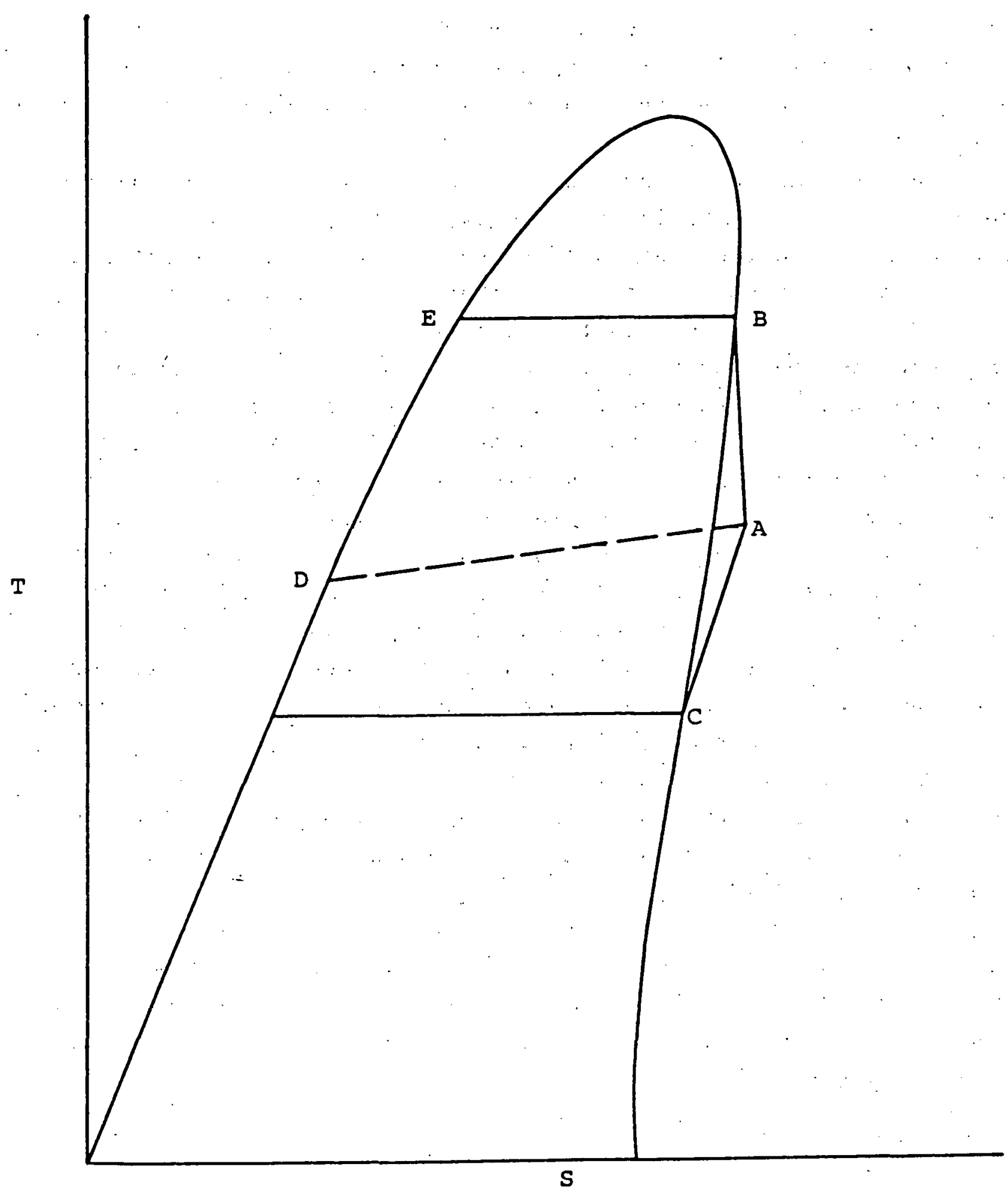

Fig. 4.1.2.2-3 Typical saturation line for organic fluid

$-71-$ 
than point $C$, the boiling temperature. Instead of the parallelogram of the ideal cycle, one is left with the pointed cycle shape, in which only an infinitesimal quantity of heat is added at the maximum cycle temperature. The cycle is therefore very inefficient compared to the ideal.

On the other hand, as shown in Fig. 4.1.2.2-3, the organics generally possess a positive slope vapor line, which permits expansion to the superheated (dry) point A from the saturated point B. By regeneration to point $C$, the arca to be compared with Fig. 4.1.2.2-1 is ADEBA and with the area ADECBA on Fig. 4.1.2.2-2. If the peak temperatures $B$ are the same for both organic and water, the saturation pressure at which the water boils (from $E$ to $C$ in Fig. 4.1.2.2.-2) is low and so is cycle efficiency. A number of other fluids besides water have been used or are being used in Rankine cycle systems: These include refrigerants (Freon 12 and 113), trifluoroethanol, fluorochemical (FC-75), isopropyl biphenyl, monochlorobenzene, toluene and pyridine. Each of these fluids has advantages and disadvantages, and at the present time no ideal fluid exists to fit all applications. In general, however, for low level heat recovery systems, most of the orgnic fluids are superior to water from a thermal efficiency standpoint.

One of the most significant recent efforts in diesel-Rankine combined cyclès is the power plant developed by Thermo Electron Corp., using a truck diesel engine compounded with an organic Rankine system (Ref. 15). A schematic of this system is shown in Fig. 4.1.2.2-4. The working fluid is Fluorinol-50, which is a mixture of 50 mole percent trifluoroethanol and 50 mole percent water. The design point characteristics are given in the shematic. Since the turbine efficiency is the most critical prarameter affecting overall system performance, a three-stage axial turbine running at $60,000 \mathrm{rpm}$ with a projected efficiency of $75.5 \%$ was selected. 


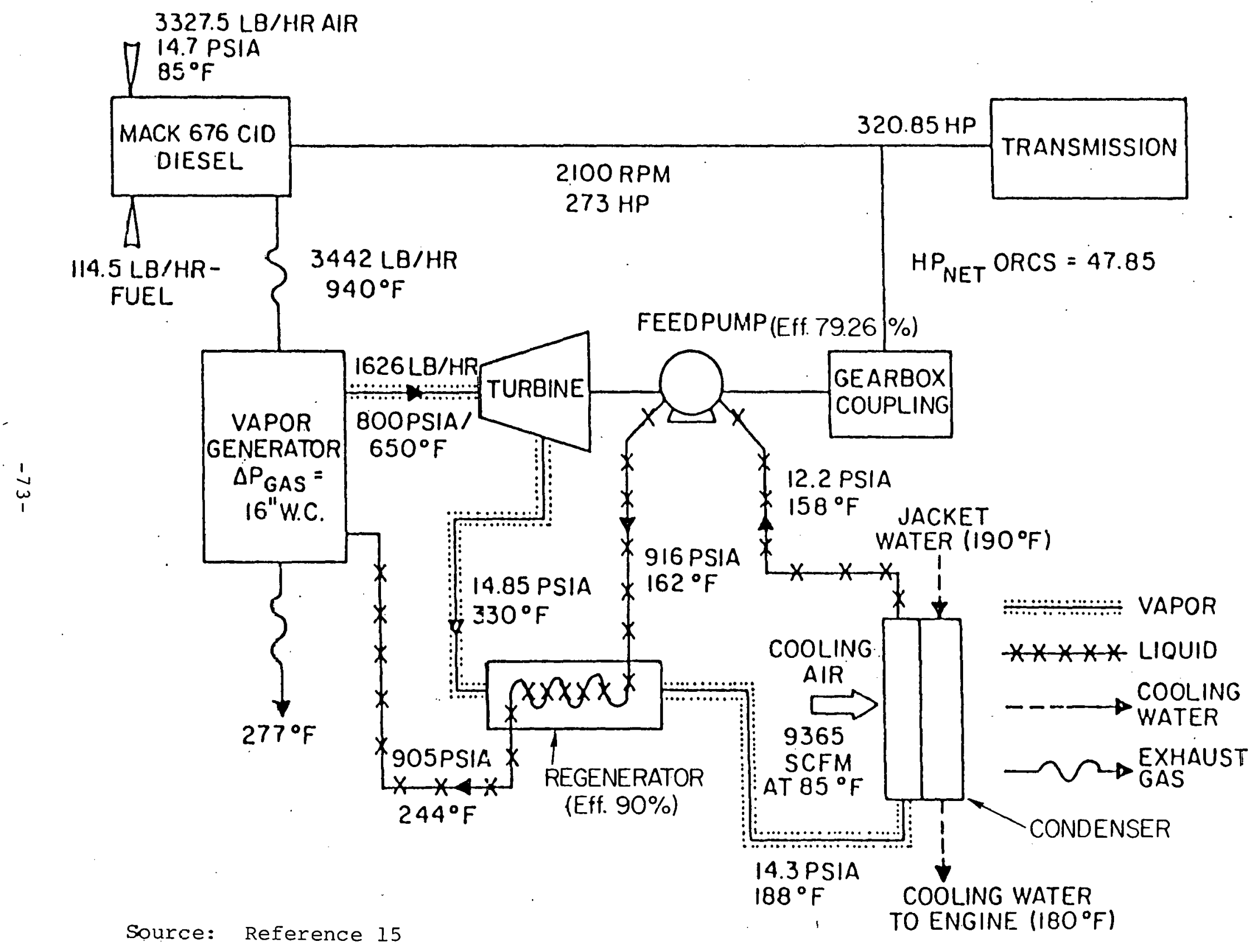

Fig. 4.1.2.2-4 Diesel-organic Rankine-cycle compound engine flow schematic 
At the conclusion of a conceptual design study, a test system was assembled using a new Mack engillt dil existing but non-optimum organic Rankine cycle hardware. Performance mapping consisted of running 26 tests over the normal operating range of the diesel engine. The maximum power obtained from the ORCS was $35.6 \mathrm{hp}$, representing a gain of $13 \%$. in power without additional fuel. On the basis of these results it was concluded that, with optimum hardware, a 15\% improvement in fuel economy over a typical duty cycle could be achieved. I'his would represent a potential reduction of 1.8 billion gals/yr. (120,000 barrels/day) in the near term transportation requirements.

A comprehenzive study of high efficiency electrical power plants, consisting of diesel engines complete with organic working fluid Rankine cycle engines was prepared for the National Sclence Foundation, Division of Advanced Energy Research and Technology, by Thermo Election Corp. (Ref. 7). The results showed that, using a commercially àvallable $37.3 \%$ efficient diescl engine in a 5.5 MWe combined cycle system, an overall efficiency of $46.3 \%$ could be achieved ( $24 \%$ power increase over the basid dilesel englul ul weru additional fuel consumption). It was also shown that, using a large experimental 4-cycle spark-1gnited yäs engine with a combus= tion air refirigeration system, lliere is a potenlial for greater than 50\% overall efficiency.

Another major effort planned for future application to a diesel engine is being initiated by sundstrand Avialiun under a contract recently awarded by DOE. This program involves the design, development, test and demonstration of a $600 \mathrm{KW}$ organic Rankine cycle, waste heat power conversion system. Prototype systems now being manufactured at sundstrand are expected to be running by the summer of 1977. Following initial tests using a laboratory heat source, it is planned to install several systems in bottoming cycle plants with diesel engines at electric utilities. A 22.5\% conversion efficiency is predicted for the organic Rankine cycle system, using toluene $(\mathrm{CP}-25)$ as the working fluid and based on cycle conditions of $5500 \mathrm{~F} / 300 \mathrm{psi}$ at the turbine inlet. 


\subsubsection{Otto Engine Improvements}

Otto cycle engines accounted for approximately $40 \%$ of the total horsepower installed in gas pipeline compressor stations in the United States between 1963 and 1973 (Gas Turbine Intern'1., '74). They probably account for half of all presently existing installations. These are spark-ignition reciprocating units operating on natural gas fuel. Many of the units are integral engine-compressor types in which some of the cylinders are used for power and the remainder for compression. Others are matched engine-compressor sets in which the engine drives a separate reciprocating compressor. Natural gas has a very high antiknock rating, making possible the achievement of high efficiency in engines through the use of high compression ratios. There are presently a number of manufactures marketing engines with compression ratios of 10.5:1 or higher. The application of turbo-supercharging has achieved further gains in power output and fuel economy, with some of the modern, high-compression, turbocharged engines showing specific fuel consumption figures at full load as low as $6500 \mathrm{BTU} / \mathrm{hp}-\mathrm{hr}$ (398 thermal efficiency).

A number of gas engines, have been installed in recent years in on-site power (also referred to as "total energy") installations. Most of these installations have been in commercial buildings where. the primary uses of waste heat energy from the engines have been for space heating, water heating, and air conditioning. The same concept has been explored for industrial applications with additional uses of heat energy such as process heating, cooling, evaporators, and possible conversion of any residual heat to mechanical energy (Ref. 16).

Only limited effort to date has been directed toward adapting bottoming cycles to gas reciprocating engines to produce additional shaft power; however, the same principles used in the diesel applications, which were discussed in Section 4.1 .2 can be adapted to gas engines. Studies have shown that adding an organic Rankine 
bottoming system to a gas reciprocator can result in more than a $20 \%$ improvement in fuel economy, even in the most efficient engines, Figure $4.1 .3-1$.

Figure 4.1.3-2 shows a typical heat balance for a four-stroke, naturally aspirated gas engine. The unconverted heat is removed through four mechanisms:
(1) Cooling water
(2) Exhaust gas
(3) Lubricating oil
(4) Radiation

The low level of lube oil temperatures $\left(190^{\circ} \mathrm{F}\right.$ or less) and of radiative surface temperatures makes the conversion of heat from these sources into useful work impractical. The primary sources for waste heat recovery therefore are jacket-water and exhaust gas. The full load heat rejection from the jacket water is seen in Fig. 4.1.3-2 to be about equal to the useful shaft work and to the energy in the exhaust. There are two possibilities tor recovery of thie energy.

The first and obvious recovery possibility is by raising steam with the heat trom the jacket. In principle, llie jacket itself could be designed as a steam generator; but practical limitations would more likely favor simply using the cooling water heat for building heat or to power absorption refrigeration equipment. Current practice is to operate with cooling water temperatures around $250^{\circ} \mathrm{F}$, which is quite compatible with standard heating and cooling equipment. At this low temperatures, conversion to mechanical power is economically beyond consideration, and no innovation proposals for such conversiun have been identlfled in the cuurse of this study. It is therefore concluded that this possibility presents no R\&D opportunity and no further work on the concept is 1 ecuinmended.

The second recovery possibility is to cool the engine internally with intake air in a manner similar to that discussed in Section 4.1.2, so that the heat appears in the engine exhaust at a 


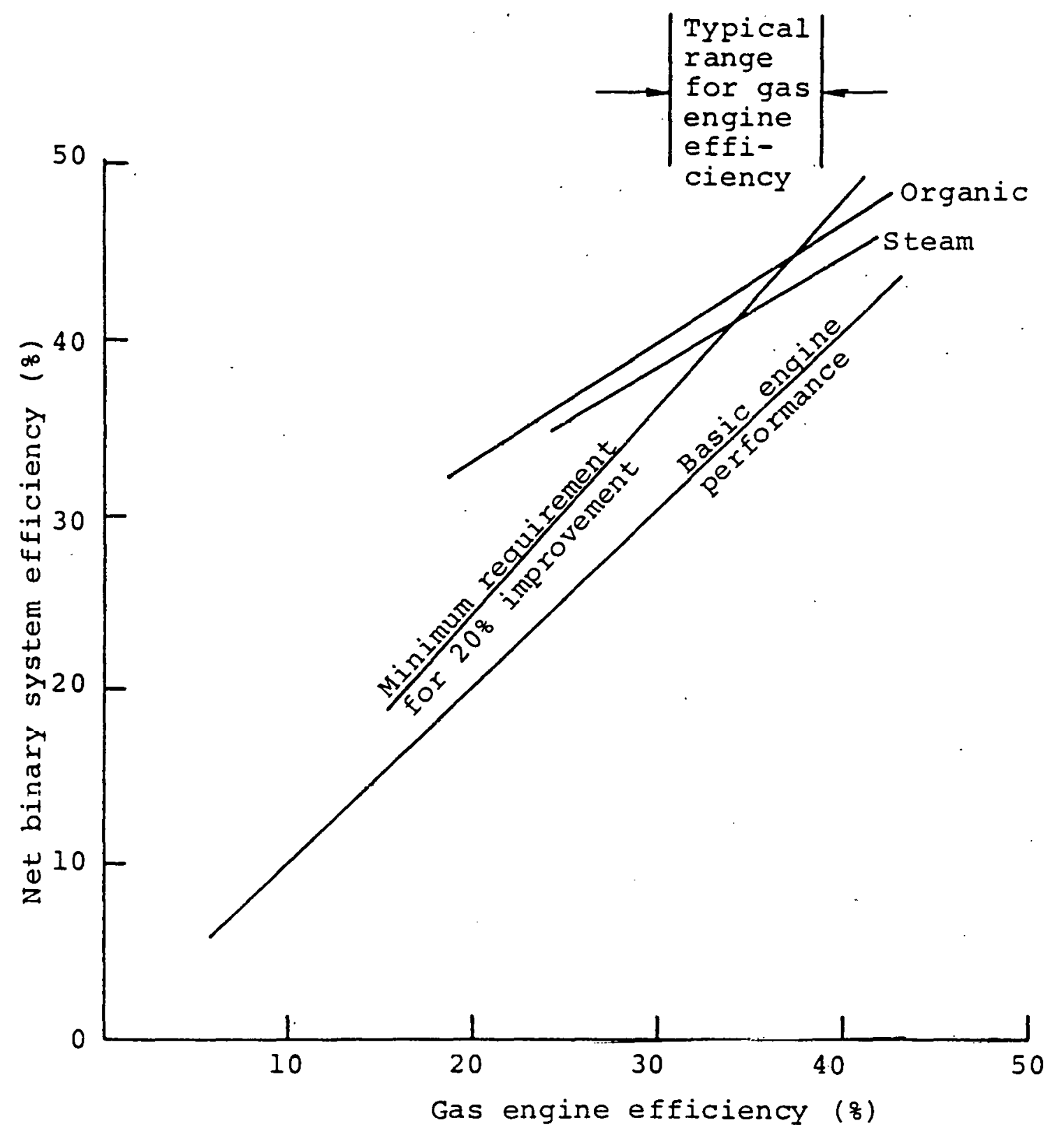

Fig. 4.1.3-1 Combined-cycle efficiency with gas reciprocators 


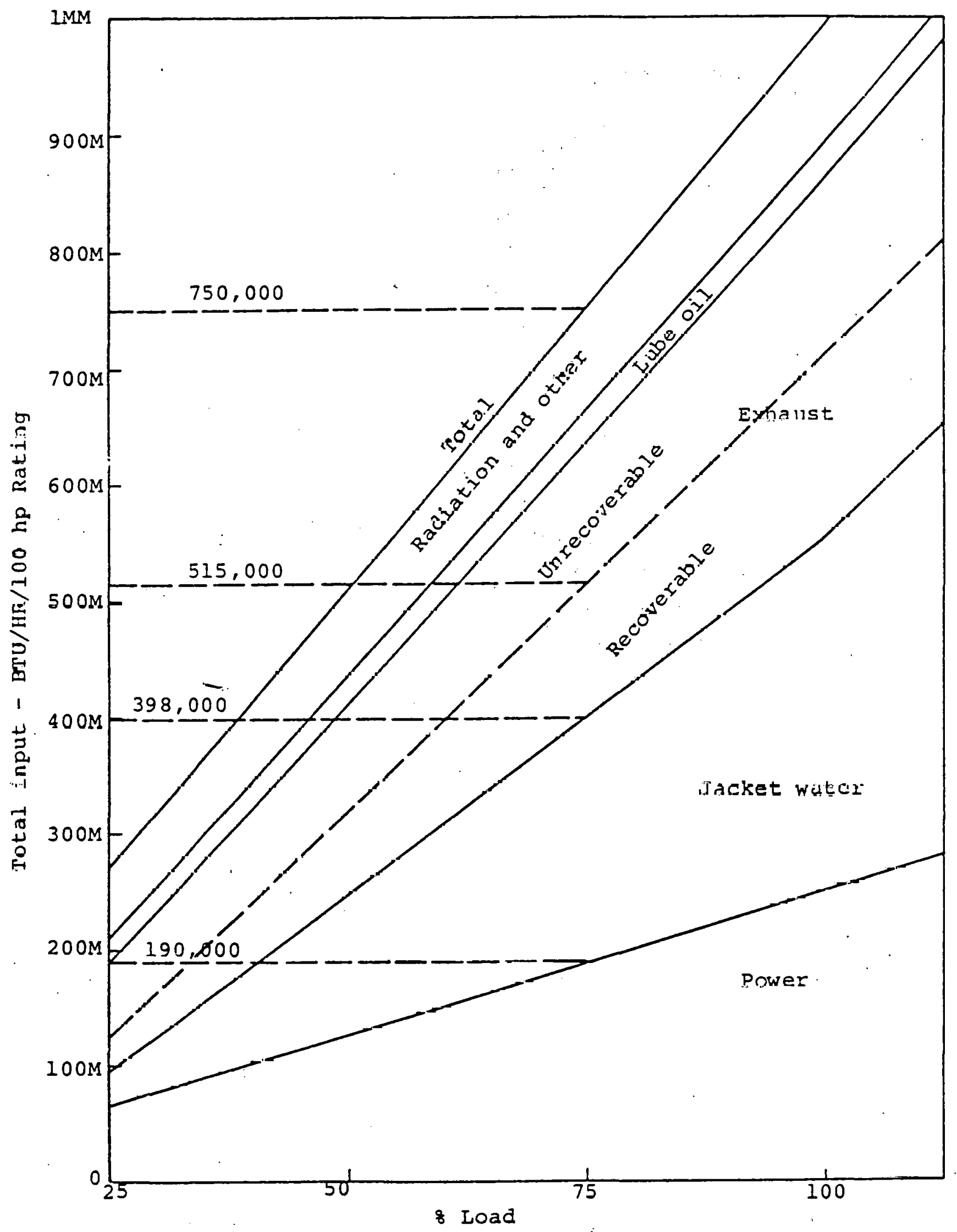

Fig. 4.1.3-2 Typical heat balance, 4-stroke, naturally aspirated gas engine 
much higher temperature than when removed in cooling water. This heat can then be converted to shaft work. in a bottoming engine to supplement the shaft output of the primary engine. This of course is equivalent to turbo-compounding the gas engine in a way similar to that discussed for the diesel engine in section 4.1 .2 above. The compounding (bottoming) engine can be either an open cycle turbine or a closed cycle engine and in principle could be either a Brayton or Rankine engine and either a turbine or a reciprocator. Internal cooling. of the gas engine therefore endows the engine with the same attractiveness for bottoming as the turbine, in which all of the unconverted heat appears in the exhaust. Figure 4.1.3-2. suggests that 25-30\% of the input energy is available to the bottoming engine. In view of this attractiveness, two additional points are worth discussion:

First, if the internal cooling development can be conducted in a way that is applicable to both gas and diesel engines, the benefits would extend far beyond the pipeline industry. They would accrue in vehicular and marine-transportation and in many stationary applications as well.

Second, it is worth noting that both the diesel and gas engines burn precious forms of fuel whose conservation holds attractions beyond the simple economics of fuel consumption. A rough estimate of the potential energetic and economic benefits of. turbocompounding may be derived as follows. It has been found elsewhere in this study (Report HCP/M-1171-2) that the eneryy consumed in gas pipelines is approximately 0.7 Quad/yr. If only $40 \%$ of this energy is consumed in reciprocating engines, and if it is practical to retrofit half of these, and if internal cooling of these could recover the 25-30\% of input which is presently lost in the cooling water, and if the bottoming engine can convert 25-30\% of that, then the energy saving would be $0.7 \times 10^{15} \times 0.4 \times 0.5 \times 0.25 \times 0.3=1.05 \times 10^{13} \mathrm{BTU} / \mathrm{Yr}$

If, natural gas is valued at $\$ 2 /$ Mcf, the value of this saving will exceed $\$ 20$ million per year. And on a flve-year payout basis, 
the justified $R \& D$ expenditures would exceed $\$ 100 \mathrm{million}$. Even if this rough estimate is several times too high, when the extreme breadth of potential application outside the pipeline industry is recognized, it is clear that an extremely attractive energy conservation opportunity lies in the internal cooling of pipeline engines. This attraction is further enhanced by recalling the discussion in Section 4.1.1.4, where it was seen that in contrast to the situation with the turbines, the older reciprocators are attractive candidates for bottoming retrofit. And by development of internal cooling, the advanced reciprocators. of the future also become attractive candidates.

\subsection{Electric Motor Improvements}

Liquid pipelines are predominantly powered by electric motors of the integral horsepower polyphase a-c type. In the reference pipeline systems, the sizes range from approximately 1500 to 3500 hp. Motors of this size are generally built by the electrical manufactures to customer specifications, including efficiencies and pnwer factors. Efficiencies are generally in the range of 90 to $95 \%$.

\subsubsection{Improvements in Motor Efificiency}

In conventional electric motors, power losses can be reduced by reducing core losses. There are several methods for doing this, e.g., adding more material to the magnetic core structure or using steel with improved core loss properties. Another method is to increase the cross sectional area of the conductors, which means adding winding material to the stator and rotor. Arother technique is to shorten the air gap, thereby reducing the magnetizing current required. These are straightforward design approaches of the type which would be used by any electric motor manufacturer in meeting specifications for high efficiency, and do not appear to warrant any significant research and development effort to improve motor efficiencies over the present industry average. 
The application of superconductors to electrical power equipment is another area which has received wide attention in recent years and is regarded as having excellent future potential for certain applications. Efforts are being concentrated on electric motors and generators as well as superconductive transmission lines.

Superconductivity is the total loss of electrical resistance shown by some materials when they are cooled to temperatures near absolute zero. Mercury, tin, lead, and many metal alloys become perfect conductors of electricity near absolute zero. Recent research has resulted in improved alloys such as niobiumtin and niobium-titanium, although the cost of these materialsd remains high (approximately $\$ 2$ per gram for the high purity metal and $\$ 30$ per pound for the regular grade).

The first efforts, in the 1960's, to incorporate superconducting windings in rotating electrical equipment were directed toward military applications in which size and weight were the dominant concerns. These programs established the feasibility of using superconductors in field windings and the need to shield the superconductor from any a-c magnetic field. Advances in superconducting magnet technology, namely, the commercial availability of stabilized NbTi conductors, were the principal causes of the recent efforts to develop large rotating electrical machinery with superconducting field windings.

In 1970, the International Research and Development Co. (IRD) of the United Kingdom demonstrated a 3250-hp homopolar electric motor with a superconducting NbTi field winding that could operate at full load in an industrial environment. Homopolar machines are variants of the Faraday-disk machine in which the armature (a thin circular disk) rotates inside an axial magnetic field. Such machines operate at low voltages and high currents (Ref. 17).

Although there has been an increasing interest recently in industrial application of high-rated homopolar machines, the main thrust of development to date has been for marine propulsion 
systems. The United Kingdom Ministry of Defense (MOD) has funded the development by IRD of a $d-c$ superconducting generator and motor suitable for use as a propulsion system for high speed naval vessels. The U.S. Navy has launched a major effort to develop a superconducting motor generator for ship propulsion systems. Design contracts for a $30,000 \mathrm{hp} \mathrm{m}-\mathrm{g}$ set have been awarded to the General Electric Co. and Garrett Corp. Two 3,000 hp prototype superconducting motors are being constructed by GE and are scheduled for sea trials beglnning in late 1977. These units will be forerunners of 20,000 to 40,000 hp motors being planned for the future. Because of the low voltage, high current characteristics, it is necessary to use liquid metal brushes to carry the heavy current across the narrow gap separating the rotor and stator. A major advance in the design of these current cullecturs is claimed by GE engineers, using liquid sodium-potassium collectors which can handle 100 times the 60-A/in ${ }^{2}$ capacity of solid collectors made of carbon-based materials and which do not wear.

For a-c machinery, the principal market area of interest has been central power stations. MIT, under a project funded by Edison.Electric Institute, developed and demonstrated a 45-kva mashine and initiated work on a machine with a capacity of 2 to 3 Mw. Westinghouse has bulll and lested a j-Mve oupcroonduoting machine, demonstrating technical feasibility of their design. Design considerations prohibit the use of superconductors in the a-c armature as the losses would be too high; lielefule, the superconductors are used in the d-c field winding only. Current collection problems for large blocks of power rule out rotating the armature winding, so the field windiny is rotated. Problems associated with a rotating cryogenic system have presented a formidable challenge to the cryogenic and structural engineers. Although both MIT and Westinghouse have demonstrated workable designs, the economics of such generators has yet to be demonstrated (Ref. 17). 
In assessing the adaptability of superconducting motors for pipeline use, there appears little likelihood that such machines will reach the stage of practical application within the next 10 years. The only types envisioned for near term use are the d-c homopolar type machines planned for marine propulsion systems, and these do not appear economically attractive except in large power sizes $(20,000$ to $40,000 \mathrm{hp})$. Although these machines offer a major advantage in power density over conventional motors, the gains in efficiency are only marginal and are largely offset by the losses involved in the refrigeration equipment. The motor sizes involved in liquid pipelines are much smaller and are a-c polyphase induction type. If superconducting $d-c$ machines were used, it would be necessary to use a 3-phase rectifier bank in order to obtain d-c output, and this output would be synchronous a-c only. For these reasons, the expenditures of any significant R\&D effort toward superconducting electric motors for pipeline application does not appear warranted at this time.

4.2.2 Improvements in speed Variability

Pipeline motors operate upon alternating current, and are therefore constant-speed machines. Control is then effected by throttling excess pressure above that which the pipe is designed to accept. This throttled energy is of course wasted, and sometimes is a significant quantity. If a cheap way could be found to vary motor epccd, either within the motor itself or in a variable-speed drive, a considerable saving of energy could be realized in petroleum-products pipelines.

An interesting possibility for accomplishing speed variability in pipeline pump motors is the use of DC motors powered by fuel cells. This concept is discussed in section 4.3.6.2.

4. 3 Fucl Cells.

The fuel cell concept and characteristics are briefly described below and shown in Figs. 4.3.1-1 through 4.3.2-4 (Ref. 18). 


\subsubsection{Fuel Cell Description}

The fuel cell was first invented in 1839, but remained little more than a scientific curiosity until the first practical fuel cell was demonstrated 120 years later by Francis T. Bacon and J. C. Frost of Cambridge University. Since that time, fuel cells have been widely used in the space program where they have proved to be reliable sources of electrical power. However, their high cost and the difficulties involved in adapting their use to conventional hydrocarbon fuels have effectively retarded their adoption as ground juwet sunities.

The fuel cell is an electrochemical device which directly combines fuel and air to produce electricity. As illustrated in Fig. 4.3.1-1, a hyrodgen-rich fuel is electrochemically combined directly with oxygen from the air to produce electricity and water. Waste heat produced by the reaction process is removed with the exhausted air. Single fuel cells can be assembled in stacks of varying sizes to produce a wide range of output levels.

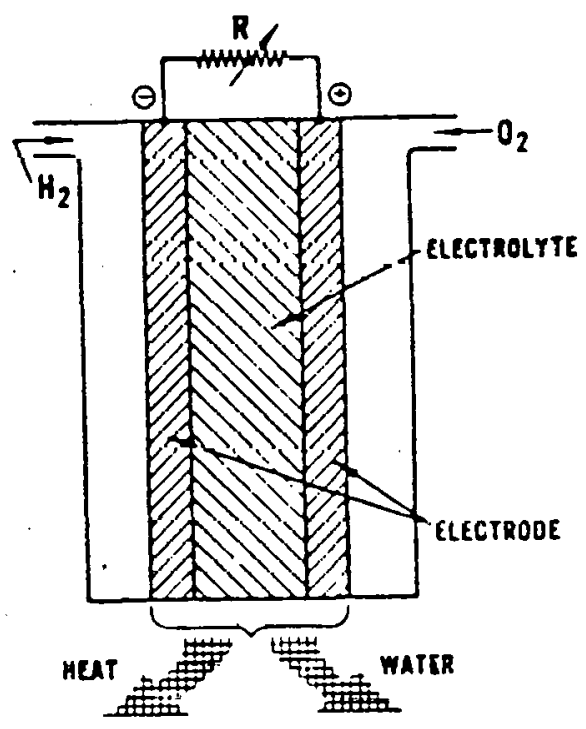

Fig. 4.3.1-1 - Fuel Cell Concept

Source: Reference 18 
Small fuel cell powerplants have been built and operated for a variety of space and military applications, and experimental demonstrations have been built for commercial applications. The specific arrangement of the powerplant is dependent on the fuel and oxidant used and the application requirements. For space applications, such as the Apollo manned voyage to the moon, the fuel cells operated on pure hydrogen and oxygen, supplying DC power for the spacecraft electrical needs. This very simple powerplant consisted of a cell stack and a few controls.

Commercial fuel cell powerplants operating on fossil fuel and air comprise three main elements as shown schematically in Fig. 4.3.1-2. The reformer section converts natural or synthetic hydrocarbon fuels into a more reactive form, usually a gaseous mixture of hydrogen with some carbon dioxide. The power section consists of a number of individual cells which convert the processed fuel with oxygen from the air to produce DC power. In the fuel cell

\section{HYOROCARBON FUEL TO ELECTRIC POWER}

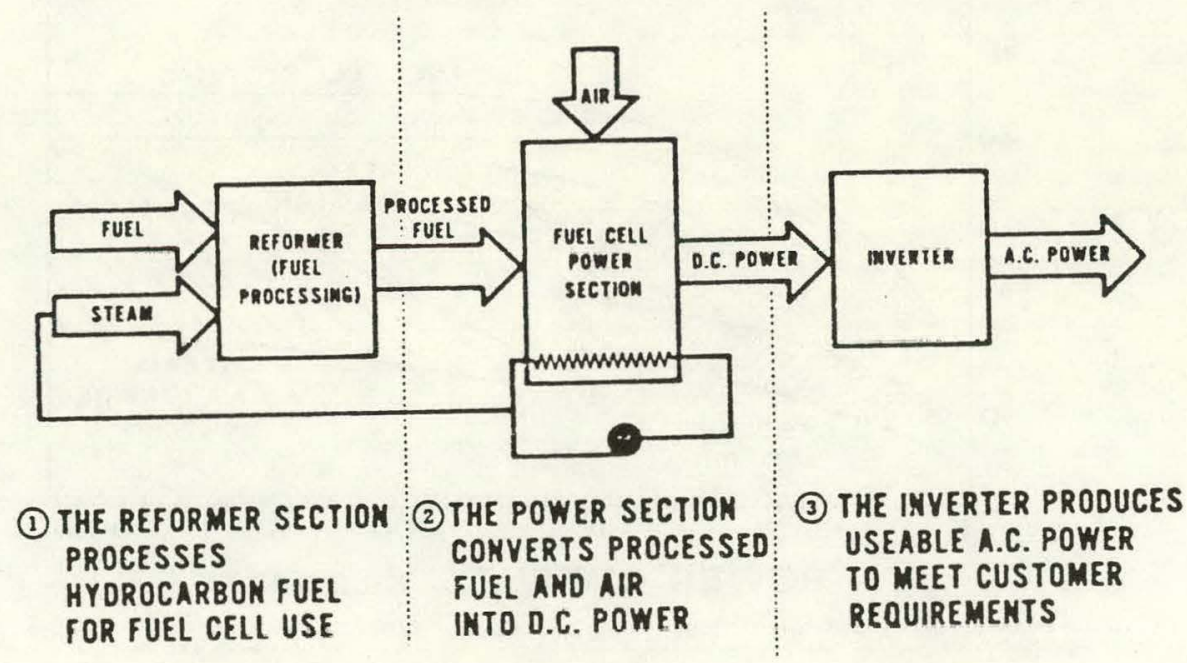

Fig. 4.3.1-2 - The fuel cell powerplant

Source: Reference 18 
stack the individual cells are connected electrically in series of permit generation of any voltage up to hundreds or thousands of volts DC. Connecting a number of cell stack assemblies in parallel permits generation of any power level from kilowatts to multimegawatts. The third major section is the inverter, which converts the DC output from the fuel cell section to alternating current (AC) electricity suitable for commercial applications.

\subsubsection{Attractive Characteristics of Fuel Cells}

Fuel cells have several unique characteristics which make them attractive for use in several power generation applications. These include the following:

(1) High theoretical conversion efficiency

Fuel cell powerplants ranging in power output from less than $100 \mathrm{kw}$ to thousands to kilowatts are potentially capable of efficiencies comparable to the best diesel electric and large steam powerplants, as shown in Fig. 4.3.2-1

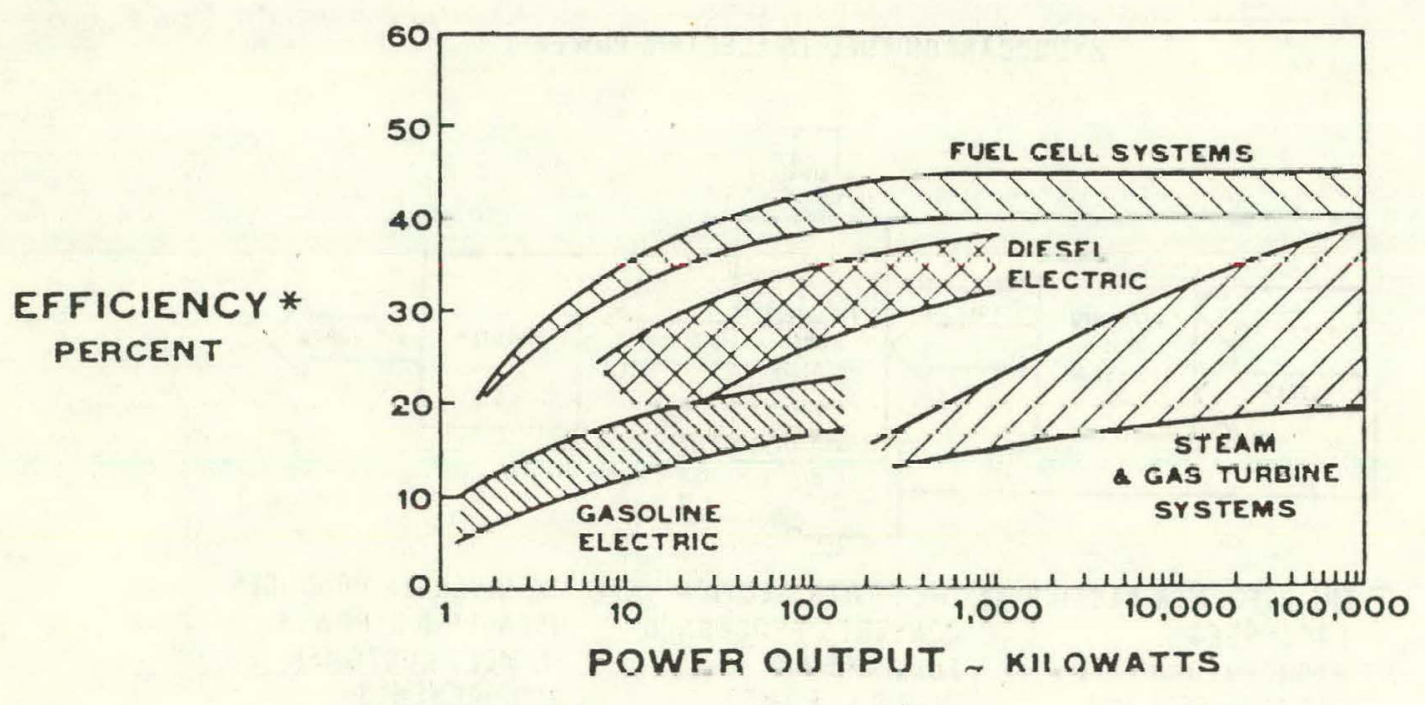

* BASEd ON LOWER heatiNg VALUE

Fig. 4.3.2-1 - Fuel economy/efficiency for all sizes

Source: Reference 18 
First generation fuel cell powerplants, using phosphoric acid electrolyte, are being developed with efficiencies approaching 40\%, while future advanced fuel cell concepts are expected to have efficiencies as high as $57 \%$.

(2) High efficiency in small plant sizes

Efficient fuel cell systems based on present concepts can be built in sizes starting at about $25 \mathrm{kw}$. Small increases in efficiency can be obtained with increasing size up to about 1 megawatt, with little efficiency gain beyond this power level. Again referring to Fig. 4.3.2-1, it is seen that fuel cell efficiencies are potentially quite good in sizes down to $10 \mathrm{kwe}$ and below.

(3) Good part-load efficiency

Unlike conventional power generation equipment, fuel cell efficiency increases as load is reduced from rated power, down to about $40 \%$ load is illustrated in Fig. 4.3.2-2. This characteristic is important, as most generating equipment, except for base load plants, is required to operate over a wide range of outputs, in many cases averaging only about $50 \%$ over the equipment lifetime.

RELATIVE PART LOAD EFFICIENCY

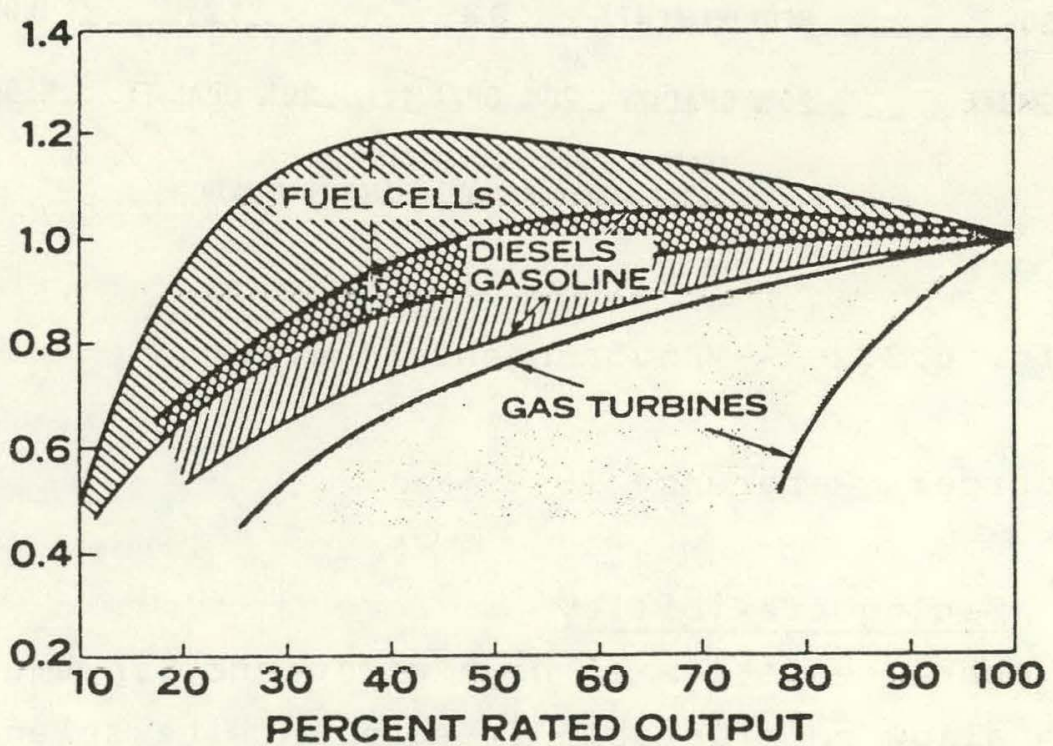

Fig. 4.3.2-2 - Fuel economy/efficiency at part load 
(4) Low noise, thermal, and chemical pollution

Because of the static nature of the conversion process, fuel cell powerplants are inherently less noisy than conventional steam and internal combustion engine powerplants. The noise sources are confined to the ancillary equipment such as liquid feed pumps, and air blowers which are required for fuel cells. Cooling water is not required since waste heat can be transferred directly to the atmosphere. Measured emissions from experimental powerplants have shown that the fuel cell exhaust contains significantly lower emissions of particulates, oxides of nitrogen, and sulfur oxide, as indicated in Fig. 4.3.2-3.

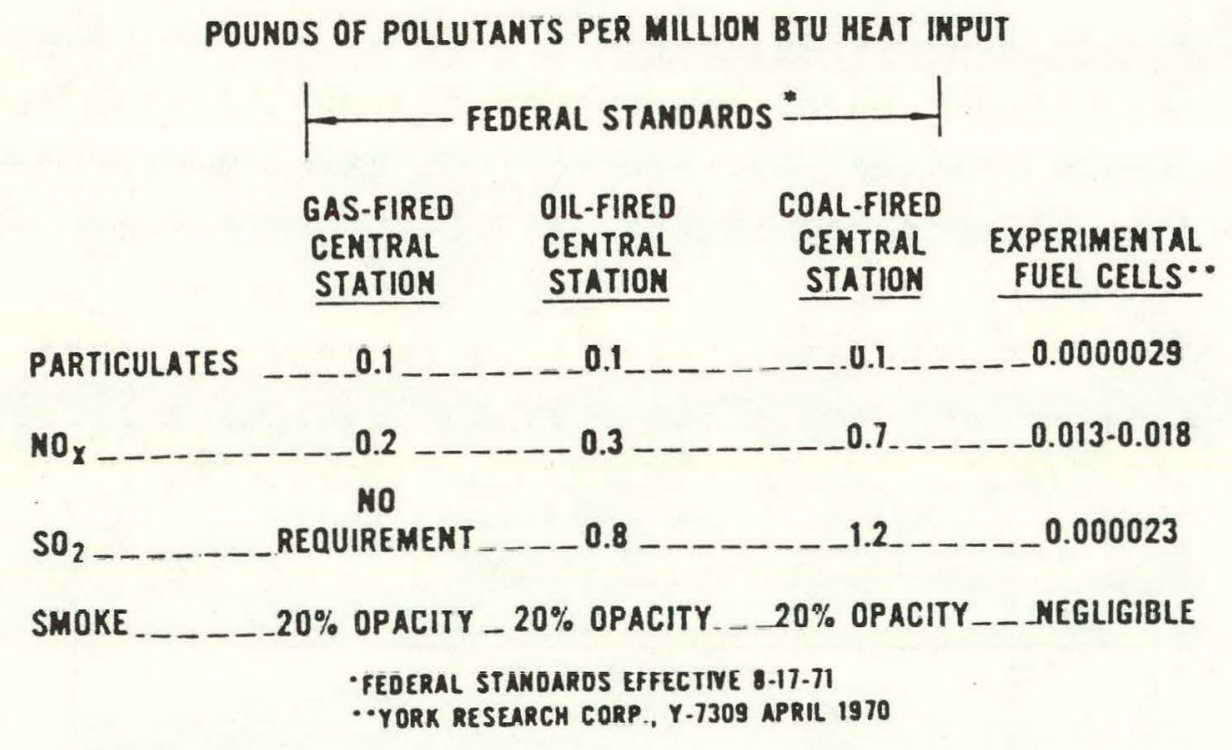

Fig. 4.3.2-3 - Environmental impact

Source: Reference 18

(5) Siting flexibility

The characteristics of high efficiency in small sizes and low pollution allow considerable freedom in site selection of fuel cell powerplants. Those systems that require a minimum of fuel processing can be placed within buildings to make direct use of some of the waste heat for space heating and cooling. Fig. 4.3.2-4 shows the relative amounts and types of waste heat available. 


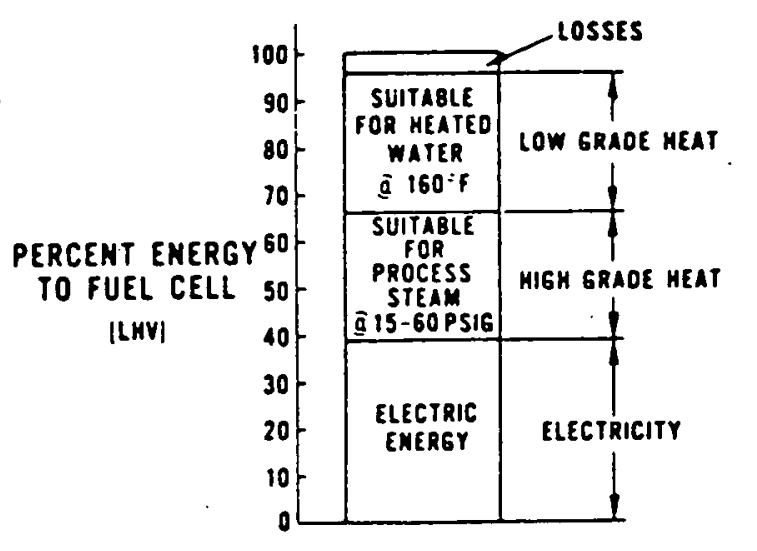

\author{
THERMAL USES \\ PROCESS HEAT/STEAM \\ ABSORPTION CHILLERS \\ - alr conoinioning \\ - refrigeration.
}

SPACE HEATING

WATER HEATING

Fig. 4.3.2-4 - Waste heat recovery potential

Source: Reference 18

\title{
4.3.3 Problem Areas
}

The primary problems associated with fuel cell development are cost and durability. For the fuel cell to produce electricity at room temperature, the electrodes must contain a very active electrocatalyst. The best catalysts discovered to date are very expensive noble metals - platinum and palladium. Nickel electrodes, which operate at higher temperatures, have electrode degradation and electrolyte decay problems. Fuel processing equipment is complex and expensive. Steam reforming, partial oxidation hydrocracking, and hydrodesulfurization are being tried with varying degrees of success. Steam reforming is a fuel processing technique now commonly being used with phosphoric acid electrolyte fuel cells. It requires a nickel catalyst, which is susceptible to poisoning by elements such as lead, chrome, and sulfur. Light distillate fuels low in contaminants give the best results with steam reforming, but the life of cuch a system is presently limited to about 15, 000 hours (approximately two years) (Ref. 19). Initial work has been done chiefly with phosphoric acid electrolyte, which has an operating temperature of 160 to $200^{\circ} \mathrm{C}$. The next generation of fuel cells, expected to have higher efficiency, will probably use molten carbonate. Opcrating at a temerature of 500 to $700^{\circ} \mathrm{C}$, this 
material is more tolerant of fuel impurities, but there are other problems yet to be solved. Life for existing molten carbonate cells is presently reported to be about 10,000 hours, as compared with a projected life of 50,000 hours by 1985 (Ref. 19). The last element in the fuel cell system, the inverter which converts DC to $A C$, does not yet exist in the sizes needed for large-scale power conversion. Recent development of large SCR's which can be used in thyristor invester circuits may be the answer, but there are a number of problems that must be overcome to meet the goal of 968 efficiency.

\subsubsection{Fuel Cell Development Status}

Fuel cells can be categorized according to their state of development into three generations (Ref. 20). Goals for the first and second generation programs of the electric utility industry are shown below (Ref. 21).

\section{Characteristic}

Commercial introduction

Capital cost (1975\$)

Life

Stack refurbishment

Heat rate $(\mathrm{Btu} / \mathrm{kwh})$

Thermal efficiency, $\frac{}{2}$

Fuel
Firct

Generation

1980

$\$ 250 / \mathrm{kw}$

20 years

$40,000 \mathrm{ks}$

$9300-9000$

$36.7-37.8$

Naptha

Natural gas

clean coal

fuels
Sersond

Generation

1981

$\$ 200 / \mathrm{kw}$

20 ycare

$40,000 \mathrm{hr}$

7500-7300

45. 5-46.8

Distillate

Naptha

Natural gae

Clean coal

fuels 
The two major programs in support of this electric utility industry fuel cell effort are the FCG-1 and RP114 programs, both initiated in 1972. The FCG-1 is sponsored by the United Technologies Corp. and nine major utilities, with the objective of bringing a first generation, 26-MW fuel cell power plant into commercial service by 1980. The nine utilities are supporting this effort through down payments on provisional orders for a total of 56 FCG-1's. The RP114 project was initiated by United Technologies Corp. and Edison Electric Institute (EEI). It is intended to broaden the application of fuel cells beyond the near-term needs of environmentally constrained utilities to result. in a second generation powerplant for the utility industry to be used in a wide variety of applications.

The Electric Power Research Institute (EPRI), upon its formation in 1973, inherited the RP114 program (Ref. 21). In 1974, EPRI expanded its fuel cell activities and implemented a comprehensive, 5-year plan, adressing four major issues critical to achieving the objectives of the second -generation fuel cell powerplant. Critical issues include the following:

(1) Participation with DOE in an early 4.8-MW demonstration of the FCG-1 technology, as a prerequisite to the second-generation program.

(2) Cost/availability of fuel cells in the near to intermediate future. In october 1974, a contract was awarded to Arthur D. Little, Inc. (RP318) to develop fuel cell scenarios and favorable means of integrating these within utility systems.

(3) Delineation of the techno-economics of fuel cells in a utility network. of primary importance is a quantification of the benefits as well as a definition of the potential fuel cell market as a function of capital cost. A contract with Public Service Electric and Cas Co., New Jersey (RP729) is providing these assessments, using the scenarios from the RP318 project. 
and is reported to have met or exceeed all of its operational and performance goals (Ref. 22), including $40 \%$ overall efficiency over a wide operating range. This efficiency figure is based on the lower heating value of natural gas fuel, and includes the inverter as well as all other elements in the system. Limitations in utility company funding have precluded early completion of the development and demonstration required to introduce the $40 \mathrm{KW}$ unit into the commercial market.

Third generation fuel cells are characterized by efficiency goals much higher than second generation systems. A goal of 50 to 608 efficiency has been established (Ret. 20). 'l'here is little existing technology for third generation systems. The only known candidate is the solid oxide electolyte system. Demonstration systems are probably 15 to 20 years away.

NASA Lewis Research Center, at the request of DOE and NSF, has studied a number of advanced energy conversion systems for central station, base load electric power generation using coal and coal-derived fuels (Ref. 23). The program is identified as Energy Conversion Alternatives Study (ECAS). The General Electric Co. and the westinghouse Electric Corp. were selected by competitive bidding to study these systems, one of which is fuel cell powerplants. In ECAS Phase I, three types of low-temperature fuel cells and two types of high-temperature fuel cells were subjected to a parametric analysis. An important part of the high-temperature fuel cell system study was the utilization of waste heat elther by a steam bottoming cycle, the coal gasifier, or both. These are referred to as integrated cases. In the westinghouse study of high-temperature fuel cells, efficiencies of 48 to 538 were projected for the zirconia solid electrlyte integrated case, and $46 \%$ for the molten carbonate system. In both GE and Westinghouse studies, the highest overall efficiencies of the low-temperature fuel cell powerplants (30 to 36\%) were appreciably lower than efficiencies of the high-temperature systems. 


\subsubsection{Technology Assessment}

While the feasibility of attaining high efficiencies in medium to large size fuel cell powerplants using fossil fuels is proven, extensive engineering development and demonstration remain to be done before overall economics, operating reliability, and durability are established. Development effort is needed on all major elements, including the fuel processing equipment, fuel cells, and inverters (Ref. 20).

\subsubsection{Fuel Processing Technology}

Although fuel processing technology is well established, a direct application of this technology will not meet the expected requirements of commercial fuel cell powerplants for the near term or the future. The particular requirements of the fuel cell application aictate new requirements for the processor. For example, for a phosphoric acid fuel cell the specification limits for sulfur and $C O$ impose stringent requirements on the fuel and fuel processor, and complex integration of the processor with the fuel cell stack is often necessary. The future U.S. energy scenarios anticipate the introduction of coal-derived fuels, which will impose new requirements on the fuel processor. In the first generation FCG-1 phosphoric acid fuel cell powerplant, the fuel processor development, though quite advanced, is by no means complete. Steam reforming is limited to lower molecular weight fuels (up to naptha). A number of advanced concepts are being developed under the EPRI program to extend the range of fuels to be processed by steam reforming. Other processes receiving attention are partial oxidation and cracking (thermal or catalytic). As far as second generation fuel cell systems are concerned, little other than systems work by UTC is being done on fuel processing for the molten carbonate system. Work needs to be done to determine the cells' tolerance to possible fuel impurities, their sensitivity to diluents, etc., in order to develop an optimum fuel processor for the molten carbonate system. 
(4) A matrix of technology programs necessary to maximize the probability of achieving second-generation guals. These include projects to improve catalysts for phosphoric acid fuel cells (in the hope of stimulating a breakthrough necessary to achieve second-generation goals); to investigate molten carbonate electrode sintering mechanisms, since the molten carbonate fuel cell is the main thrust of the RP 114 program; and to assess techniques for removal of $\mathrm{CO}_{2}$ from the fuel stream in the alkaline fuel ce11:

The FCG-1 program is being accomplished by scaling up from kilowatts to megawatts in steps: (a) a 1-MW pilot plant, (b) a 4.8MW demonstration plant; and (c) several 26-MW demonstration plantis, all to precede the manufacture of $26-M W$ FCG-1 powerplants on a production basis. The 1-MW pilot plant has been built and tested successfully. The 4.8-MW demonstration plant is under contract, jointly funded by ERDA ( $\$ 25$ million), EPRI ( $\$ 5$ million), and UTC (\$12 milinn). Delivery is scheduled for mid-1978 and torting by early 1979. Results of testing the 1-MW unit indicate that the 4.8-MW plant will meet the performance goal uf 9300 Dtu/kw-hr at rated output.

Another major program called TARGFT (Team to Advance Rezearch for Gas Energy Transformation), sponsored by United Tecluulogies Corp. (UTC) and a number of companies in the gas induatry, is aimed at providing a family of fuel cell powerplants in the 25-250 $\mathrm{KW}$ range for on-site power generation in buildings and al industivial locations. This program began in 1967 and was sponsored by 28. natural gas transmission and distribution ulilities. It has since expanded to include gas utilities and combination gas and electric utility companies. The program has been jointly funded at $\$ 56$ million for effort from 1967 to the present. On the basis of market studies, $40 \mathrm{KW}$ was selected as an appropriate size for initial entry into commercial and multiresidential markets. As a result, work has been directed toward development of a $40 \mathrm{KW}$ powerplant, designated PC18. A pilot PC18 powerplant has been tested 


\subsubsection{Fuel Cell Technology}

For terrestrial applications, fuel cells can be categorized by operating temperature: low = ambient to $200^{\circ} \mathrm{C}$, intermediate $=$ $2000^{\circ}$ to $700^{\circ} \mathrm{C}$, and high $=$ above $700^{\circ} \mathrm{C}$. The first generation fuel cells will operate in the low temperature range. The problems most common to fuel cells in this category are in the area of electrocatalysis, invariant. cell life, and system cost. In the intermediate temperature category the major problems are to develop the materials to assure long cell life in the severe conditions of high temperature and corrosive environment. In the high temperature category, using solid-oxide electrolyte, the materials problems will be more difficult to overcome than for the intermediate range. 4.3.5.3 Power Conditioning Technology

The basic element of the fuel cell. power processor is the inverter, which accomplishes $D C$ to $A C$ power conversion. Inverters designed for low power applications are commonplace. However, large-scale inverters capable of handing megawatts of power have not been built, largely because of lack of semiconductors which can handle the large currents and voltages. In addition, the common designs are handicapped by poor efficiencies. UTC, working with semiconductor manufacturers, has developed and tested inverters for the TARGET program capable of handling 20 and $40 \mathrm{KW}$ power levels. They are also testing a $1.8 \mathrm{MW}$ unit inverter for use as a building block in the FCG-1 power processor, using components proved in the TARGET program. The scale-up is accomplished by operating the SCR's in a series/parallel combination to accommodate the higher fuel cell power voltages. Potential problems in the scale-up include:

(1) Simultaneous triggering of the SCR's, which are operated in series. Simultaneity is necessary to prevent excessive voltage buildup on the late-firing SCR's.

(2) Possible unbalanced load current sharing among SCR's operated in parallel; and 
(3) Undetected failure of individual SCR's or drive circuits, resulting in overloading of the remaining SCR's. The UTC goals show a target efficiency of $96 \%$ for the FCG-1 vs a demonstrated $90 \%$ on the $25 \mathrm{KW}$ TARGET inverters. Although some improvements can be expected from the scale-up to the megawatt size, efficiency, compatibility, and life tests will be required to verify des̈ign goals. 


\subsubsection{Pipeline Applications of Fuel Cells}

In Section 4.2 .2 above, it was noted that, if an economical and efficient means could be found to vary the speed of the pump motors, an appreciable saving in energy could be realized. To understand the losses that are thus avoided, it is necessary to examine products pipeline duty cycles in some detail.

\subsubsection{Duty Cycles in Products Pipelines}

There are two throttling conditions that arise in pipeline operation, depending upon whether the system is asked to pass maximum throughout or to accommodate to a specified pumping schedule below maximum capacity. These variations in duty arise from seasonal variations and from the necessity to switch products in order to accommodate all shippers' requirements. As an example of the former, the demand for fuel oil and LPG increases in the fall and winter, whereas in the spring and summer the traffic is predominantly gasoline. The switches to accommodate shippers arise because of the necessity, as a common carrier, to serve all shippers without discrimination. Thus common carrier products pipelines operate in products cycles of seven to ten days during which they guarantee to accept for shipment at least a (proportionate) part of every tender.

It may be noted in passing that similar situations can arise in crude lines if different types of crude are found in proximity to each other. However, this seldom occurs, so that the discussion here refers only to products lines. These conditions are discussed in reverse order, in the sections that follow.

$$
\text { 4.3.6.1.1 } \frac{\text { Throttling losses at less }}{\frac{\text { than maximum throughout }}{\text { Because of lower }}}
$$
capital and maintenance costs and ease of operation, the large majority of liquid pipeline system pumps are driven by constantspeed electric motors. Except for older, small-diameter systems, 
generally crude oil gathering, the pipeline pumps are centrifugal units which are directly coupled to an electric motor driver and therefore rotate at the same speed as the motor. The available driver-pump options are, with few exceptions:

(1) Constant speed electric motor driving a centrifugal pump through a variable-speed coupling

(2) Variable-speed electric motor directly connected to a centrifugal pump

(3) Constant-speed belt drive connecting electric motor and positive displacement pump

(4) Variable-speed engine driving either centrifigal or positive displacement. pumps.

The disadvantage of the constant-speed motor directly connected to the centrifugal pump is the inflexibility of pump speed and therefore the inability to vary the pumping rate and the velocity of the liquid in the pipeline.

With constant-speed motor-centrifugal pump units, flow variations are obtained by either or a combination of the following :

(1) Pumping through rontrol valves that waste controlled amounts of the pump full discharge pressure in order to decrease line pressure and flow velocity to the specific flow required by the shipping schedule.

(2) Installing multiple pump and motor units at each pump station to operate either in series or parailel, in combinations that yield the specific flow required by the shipping schedule.

When a pipeline company is responsible for transporting a fixed quantity of liquid over a fixed time period with electric-motor driven centrifugal pumps, the management has the option of: 
(1) Selecting the most nearly optimum combination of the availabie pumping units and pumping every minute of the time allotted at a constant average rate, throttling excess energy by a control valve, or

(2) Pumping with a selected number of units, without wasting pressure in a control valve, but pumping at a faster rate than necessary; thereby wasting energy both in start/stop and in increased fluid friction loss.

(3) Pumping under a combination of part time without throttling and part time with throttling, in such proportion that the average flow. is the required one.

The lack of ability to adjust pipeline flow with economical and efficient variable speed motors or couplings results in one or more of the following economic losses: :

(1) More pumps and motors are'installed in a system than otherwise would be necessary.

(2) Energy is wasted when pressure is reduced by throtting in a control vaive.

(3) Energy is wasted in fluid friction when flow in a pipeline is at a higher velocity than necessary.

(4) Energy is wasted by start/stop transients; however, this loss is not usually significant.

Although variable speed drivers and couplings are available, they are characterized by high initial capital costs and low efficiences, so that economic analysis for most pipeline systems results in the direct coupling of constant speed motors to centrifugal pumps.

It is instructive to consider an example representing the following conditions : 
(1) Pumping schedule - 30,000 bbl/day of medium-viscosity petroleum products.

(2) Pump-motor combined efficiency - 85\%.

(3) Pump and system characteristics as shown on Figure 4.3.6.1.1-1.

The operating options, together with the associated increases in necessary installed capacity and in energy consumption, are listed in Table 4.3.6.1.1-1. It is seen that the increase in available horsepower required is about 30\%, and the energy wastage is from 5 to 30\%. It is to be noted that the least wasteful option (1) does not include the energy wasted in the transient.

If the flow requirement were such that it became necessary to bring a third pump on stream, point e shows the flow below which throttling is required to maintain allowable line pressure. This limiting pressure constitutes the limit upon system capacity. The examples in the table relate to limits imposed by pump capacity. Both limits can be important in the operation of the pipeline. 


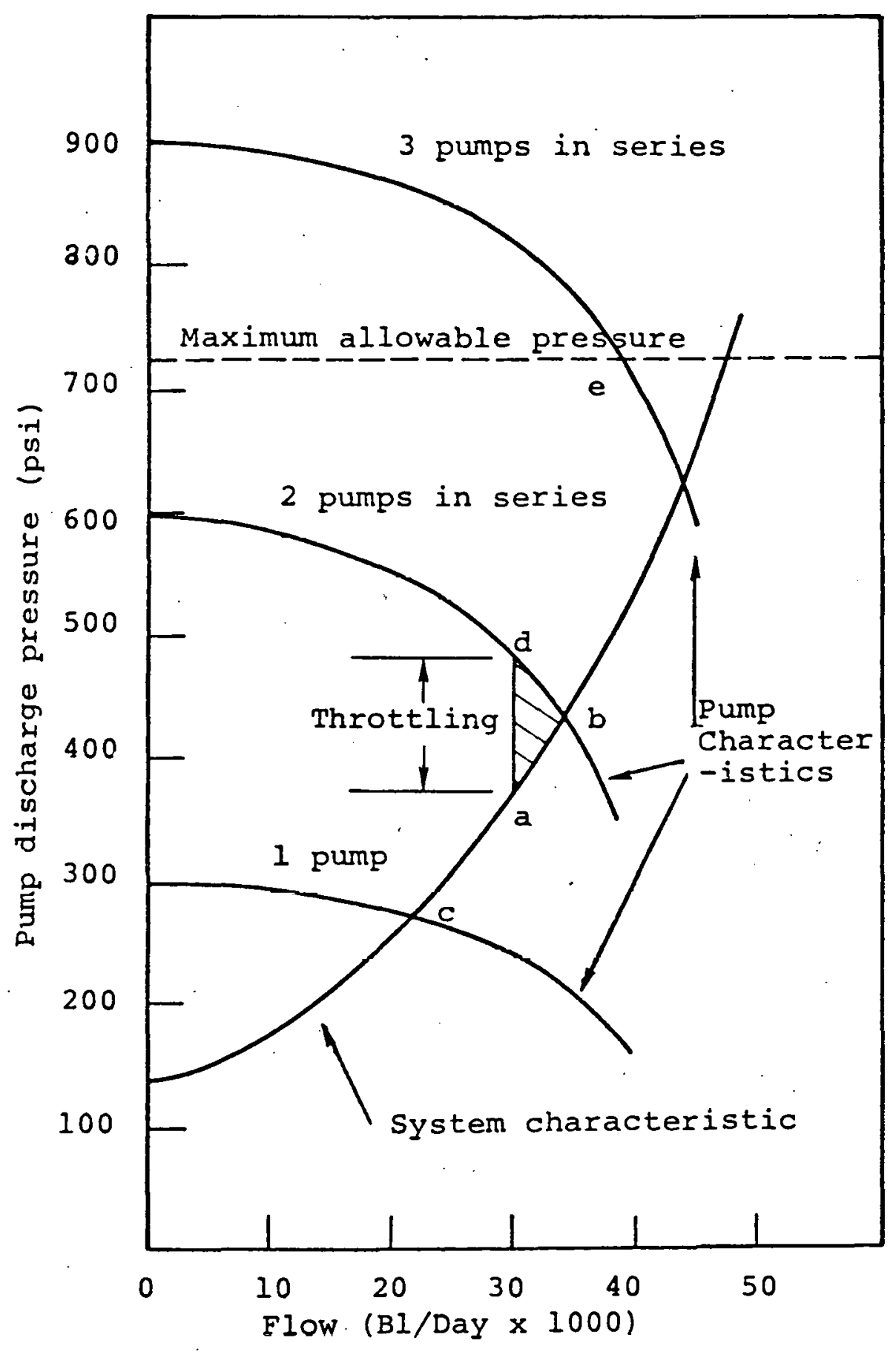

Fig. 4.3.6.1.1-1 - Pump and system characteristics 
Table $4 \cdot 3 \cdot 6 \cdot 1 \cdot 1-1$

Energy Wasted By Operating Options Available with Constant-Speed Pumps

(1) - Ideal - Operating Point a (unattainable)

$30,000 \mathrm{bbl} / \mathrm{day}$ @380 psi for $24 \mathrm{hr}=24 \mathrm{x} 228 \mathrm{hp}=5472 \mathrm{hp}-\mathrm{hr}$

(2)- Operating on split rate schedule (attainable) .

Point b

$34,000 \mathrm{bbl} / \mathrm{day} Q 440 \mathrm{psi}$ for $16.3 \mathrm{hr}=16.3 \times 299.2 \mathrm{hp}=4877 \mathrm{hp}-\mathrm{hr}$

Point $c$

$21,500 \mathrm{bbl} / \mathrm{day} 0276 \mathrm{psi}$ for $7.7 \mathrm{hr}=7.7 \times 118.7 \mathrm{hp}=914$

$5791 \mathrm{hp}-\mathrm{hr}$

Increase over ideal $71.2 \mathrm{hp}$ capacity $319 \mathrm{hp}-\mathrm{hr}$ average $31.2 \%: 5.8 \%$

(3) - Operating two pumps and throttling (attainable)

point d

$30,000 \mathrm{bbl} / \mathrm{day} @ 495 \mathrm{psi}$ for $24 \mathrm{hr}=24 \times 297 \mathrm{hp}=7128 \mathrm{hp}-\mathrm{hr}$

Increase over ideal $69 \mathrm{hp}$ capacity $1656 \mathrm{hp}-\mathrm{hr}$ average $30.2 \%$

(4) - Operating two pumps wide open (attainable)

Point b

$34,000 \mathrm{bbl} /$ day $@ 440 \mathrm{psi}$ for $21.17 \mathrm{hr}=21.17 \times 299.2 \mathrm{hp}=6334 \mathrm{hp}-\mathrm{hr}$ Increase over ideal $\quad 71.2 \mathrm{hp}$ capacity $862 \mathrm{hp}$-hr average $31.2 \%$ 


\subsection{Throttling losses at maximum throughput}

It has been seen in the preceding section that when the schedule calls for delivery at full capacity of two pumps, the optimum operating point is at $b$ in Fig. 4.3.6.1.1-1. However, as will be seen from the discussion to follow, even when the demand exceeds capacity, it is seldom possible to achieve that optimum operating condition. The reason lies in the nature of the pipeline duty cycle, and can perhaps best be explained by an example, which accordingly is presented in Figs. 4.3.6.1.2-1 through -18. The case presented is a section of an actual, existing pipeline, and the duty cycles in the example are representative of those imposed upon that line in its day to day operations.

In -1 is seen the hydraulic gradient when the linefill is all gasoline, flowing $1000 \mathrm{bbl} / \mathrm{hr}$. The associated pressures are identified, i.e., 682 and 64 psi at the upstream and downstream ends of the section respectively. The power requirement of $1000 \mathrm{hp}$, shown at the initial station at which it is applied, is the maximum single-unit capacity at that station.

In -2 , a second 1000-hp unit has been brought on line at the midpoint station. Throughput is $1500 \mathrm{bbl} / \mathrm{hr}$, only a $50 \%$ increase for a $100 \%$. power increase. In -3 , a third 1000-hp pump has been brought on line at the quarter point. The effect of a fourth unit at the three-quarter point is shown in -4 . Total power has now risen to $4000 \mathrm{hp}$ and flow is $2200 \mathrm{bbl} / \mathrm{hr}$.

Now, second 1000-hp units.will be activated at each station in turn. When the second units are activated at the upstream station $(-5)$ and at the midpoint station $(-6)$; the flow is still only $2650 \mathrm{bbl} / \mathrm{hr}$ (shown as the gradient after the midpoint station).

When further increase in flow is attempted by activation of a second unit at the quarter point $(-7)$, throttling 
becomes necessary to avoid excessive pipe pressures at the quarter and midpoint station discharges. A total of 337 psi is throttled away at these two stations. Addition of a second unit at the three-quarter point $(-8$, solid lines) increases flow to 3060 , without throttling, but when an additional $600 \mathrm{hp}$, the last available unit, is brought on the first station, throttling again becomes necessary at the first and second stations ( -8 , dashed lines), while flow is increased by only 40 barrels. This is the maximum possible flow with an all-gasoline linefill. In practice, this last increment of $600 \mathrm{hp}$ would almost never be justified for the small flow increment that it provides.

From the foregoing, it has been seen that throttling may be necessary at both maximum flow and a number of intermediate flows below the maximum. These throttling losses could be avoided if an economical, efficient, variable-speed motor or coupling were available.

It may be noted that the final discharge pressure at the downstream end of the section varies in the foregoing cases between a low of 11 psi and a high of 99. The pressure requirement at that point may vary, depending upon whether the fluid is being diverted into storage or into tankers for transport. Whatever the requirement, any excess pressure represents an energy wastage which could be eliminated if appropriate means of pump speed control were available.

Now suppose that the schedule calls for fuel oil to begin movement through the line, following the gasoline. The profile which exists as the oil approaches the quarter point section is shown in -9 . The last available pump unit of $600 \mathrm{hp}$ at the initial station, shown in -8 as the dashed lines, is not in service in -9 , leaving $2000 \mathrm{hp}$ in service at that station. 
The allowable line pressure is exceeded at the first and third stations, resulting in throttling energy waste at those two points.

There is also another interesting difference between the situations portrayed in -8 and -9 , namely, at the downstream end of the section. With the throttling at stations 1 and 3 , the flow is reduced to $2700 \mathrm{bbl} / \mathrm{hr}$ in -9 from the 3060 in -8 , and one unit at station 4 has been deactivated. Even so, the pressure at the downstream end of the section is 104 psi, which may exceed the requirement at that point and thus constitute a waste.

As the fuel oil approaches station 3 in -10 it is seen that the 1000-hp unit in station 1 has been replaced by the 600-hp unit to avoid throttling from $1422 \mathrm{psi}$ to $1330 \mathrm{psi}$ at station 1 and from 1608 to 1461 at station 2. It is still necessary to throttle station 2 from 1461 psi down to 1328 psi. Flow is now down to $2500 \mathrm{bbl} / \mathrm{hr}$ from the previous 2700 .

In -11 , as the fuel oil is approaching station 3 , two profiles are shown. The solid line is the profile that would be required to hold the $2500 \mathrm{bbl} / \mathrm{hr}$ flow from the previous figure, i.e., activation of a second 1000-hp unit at station 4. Station 2 would then be throttling from 1553 pis to 1328 , and station 3 from 1503 to 1424, while the downstream discharge pressure would be $530 \mathrm{psi}$. By not activating the additional pump at station 4 , only $80 \mathrm{bbl} / \mathrm{hr}$ of flow is lost, discharge pressure is held to $34 \mathrm{psi}$, and some, though of course less, throttling is still necessary at station 2, from 1461 psi to 1328 , and at station 3,1424 to 1330 .

The situation when the entire line fill is fuel oil is depicted in -12. Flow is $2500 \mathrm{bbl} / \mathrm{hr}$ with eight pumping in service, and throttling is necessary at stations 2,3 , and 4 . 
Now consider the case in which propane instead of fuel oil follows the gasoline. Earlier, -8 has shown that, with all nine pumps operating, $3100 \mathrm{bbl} / \mathrm{hr}$ of gasoline could flow. When propane is introduced at the upstream end, the profile is as shown in -13 as the propane approaches station 2, and as in -14 as the propane approaches tation 3. The controlling segment is always the one just ahead of the propane. In -15, solid line profile, as propane approaches station 4, that station requires $2000 \mathrm{hp}$ to maintain the flow. However, the dashed line shows that $1000 \mathrm{hp}$ can be dropped from that station at a sacrifice of only $40 \mathrm{bbl} / \mathrm{hr}$. Note also that gasoline has been introduced upstream and has filled the first segment, requiring that $1,000 \mathrm{hp}$ be added at station 1 , of which a large part is throttled away.

In -16, the propane is approaching the terminal. The 600hp unit in station 1 has been dropped and seqment 2 is control= ling, 130 psi being throttled there. Flow is $2849 \mathrm{bbl} / \mathrm{hr}$. As the gasoline approaches station 3 (shown in -17), segment 1 takes control. The upper line shows the profile that would obtain if all three pumps in station 1 remained on line. The entire pressure contribution of the 600-hp unit would be throttled away, 239 psi at station 1 and 145 (1504 down to 1359 psi) at station 2. Accordingly, that pump is switched off without loss of flow, and segment 2 assumes control.

Figure -18 simply shows the profiles when the linefill is all propane. With its lower density, the full head with all units pumping never exceeds allowable line pressure. The last $600-\mathrm{hp}$ increment of power at station 1 gains $120 \mathrm{bbl} / \mathrm{hr}$ of flow.

Figure 4.3.6.1.2-19 shows how the actual unit power cost varies with throughput. Disregarding flows less than 1000 $\mathrm{bbl} / \mathrm{hr}$, below which the demand change dominates, it is seen that for a factor of 3.2 in throughput, i.e., 1000 to $3200 \mathrm{bbl} / \mathrm{hr}$, power cost rises by a factor of 4.4 , or approxi- 
mately as the 1.28 power of the flow. Figure 4.3.6.1.2-20 shows barrel-miles and power cost in cents/barrel mile for the 15-month period of the study.

The throttling pressures are plotted in Fig. 4.3.6.1.2-21 for the full-capacity profiles, -8 through -17 . In the uppermost plot of energy wasted at the terminal, it has been assumed for simplicity that pressure up. to $15 \mathrm{psi}$ could be used in moving the product to storage, but that any pressure above that value represents wasted energy. Since the times between the successive figures are roughly the same in each instance. (5-6 hr), if the operations are continuous, then these pressure profiles are approximately equivalent to time traces of the energy wasted per unit of flow. It is clear that the energy wasted in typical operation is not insignificant.

\subsubsection{Fuel Cells with DC motors}

The reader will have anticipated the principal conclusion of this section: direct-current motors, with their capability for infinitely variable speed control, offer a means to avoid the throttling waste discussed above. They are not used, of course, because of the expense of the converter to convert the AC power provided by electric companies to DC. But the fuel cell is a source of direct current and thus is compatible with the variable speed DC motor. It will be recalled liat the fuel cell development prograns that were described in section 4.3 .4 above included the development of an inverter to convert the fuel cell DC current to. AC. If fuel cell development is justified for the electric utility situations which require the inverter, then. it should be even more attractive for the pipeline application where the inverter is not needed. Qualitatively at least, one can say that pipeIine service offers one the most attractive application for the initial demonstration and commercialization of large fuel cells. To render this statement quantitative requires some 
discussion of the economics of pipeline energy consumption and of prospective fuel cell efficiency.

Referring again to Fig. 4.3.6.1.2-2I, it has been observed that the abscissa also roughly represents a time scale, if the operations described above are continuous, with each spacing representing approximately six hours. A further step in the analysis would be to calculate these time steps exactly and convert the throttling pressures to horsepower and replot the results, giving time profiles of power wasted at each station. Integration of these curves would then yield the energy wasted. However, for this calculation to yield an estimate of the energy actually wasted in the industry, it would be necessary to write a computer program, characterize each pipeline individually, and input that data, along with the full-year duty cycle of each pipeline into the computer, a task which is clearly impractical.

A very rough cctimato of tho onergy wated may be developed in the following way. The total operations expenses of the 105 interstate oil pipelines in 1974 was $\$ 357,122,000$. The ICC statistics do not further subdivide this figure, although in the individual company reports the cost of fuel and energy is reported. Reference to a few of those reports reveals that a figure of 40 for that cost, fuel and energy is not atypical. If that figure were valid, the energy cost for all companies would have been approximately $\$ 140$ million. For the set of full capacity profiles presented above in Figs.4.3.6.1.2-8 through -17 , the average throttling head loss is approximately 6 to $8 \%$. If this fraction were valid nationally, the total wastage would be around $\$ 10$ million annually. This order of potential saving is clearly enough to justify a R\&D program of several million dollars. 
Another question of course is that of fuel cell efficiency vs utility electric power. The latter seldom reaches $25 \%$ after all power generation and transmission losses are taken into account. It was noted in section 4.3 .4 above that fuel cell efficiencies of 45 to $47 \%$ are expected in the large second-generation units presently under development. When losses in conversion and transport of the fuel are accounted for, the net efficiency of the fuel cell power source will be reduced somewhat but will still far exceed the electric utility power source.

It is not suggested that the ready adaptability of fuel cellDC motor power sources to pipeline applications is an established conclusion. Any experienced operator of motorized equipment will testify to the large maintenance burdens which are imposed by DC motors. This fact is very important in pipeline operations, where the motor locations are often remote and/or unattended, and where round-the-clock service is often required. However, the potential clearly exists for significant energy saving, and it is therefore strongly. recommended that further work be done to define an appropriate $R, D \& D$ program for the applications of fuel cells in pipeline service. 


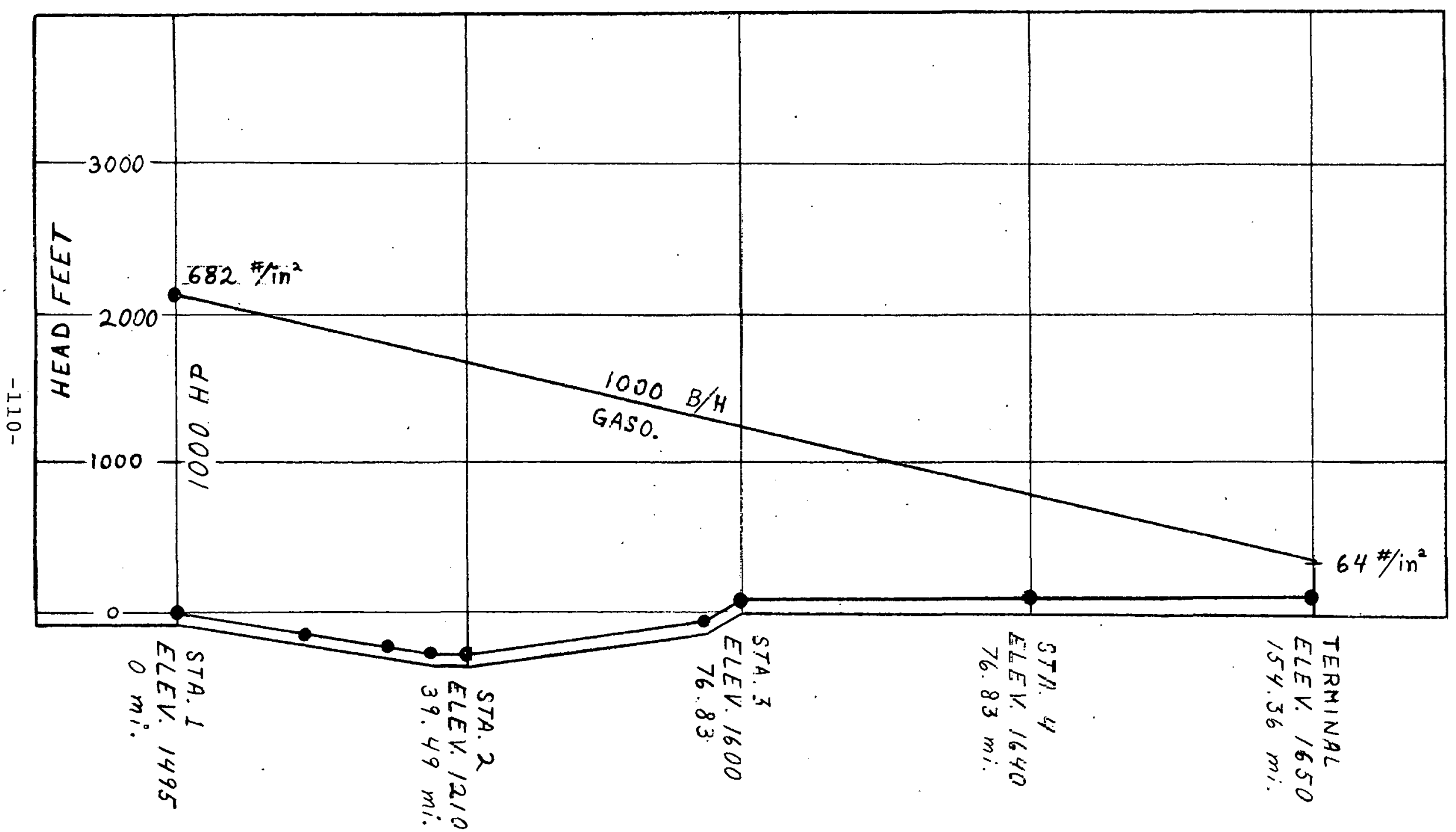

FIGURE 4.3.6.1.2-1 - HYDRAULIC GZADIENT, ONE PUMP, ALL GASOLINE 


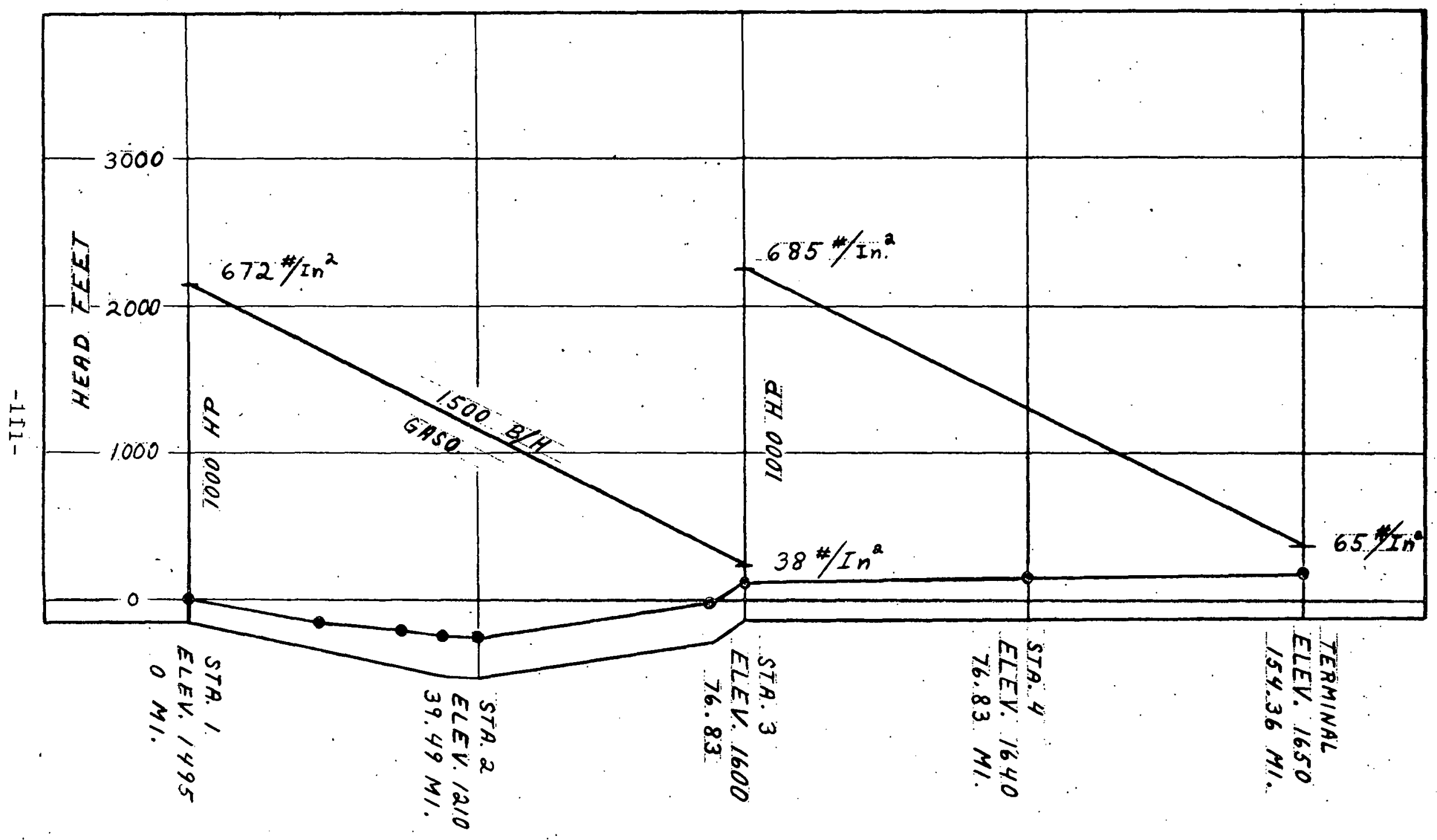

FIGURE 4.3.6.1.2-2 - HYDRAULIC GRADIENT, TWO PUMPS, ALL GASOLINE 


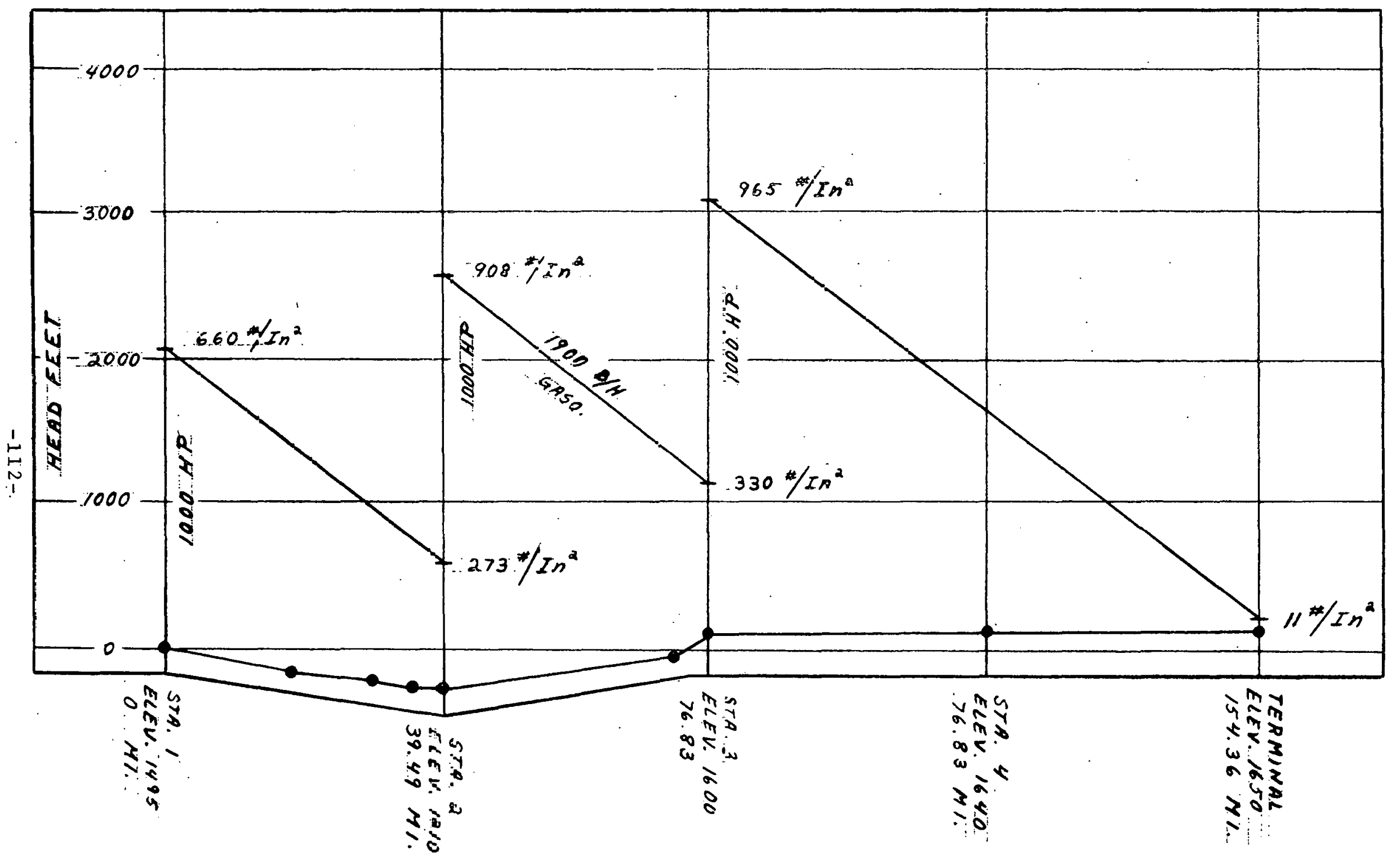

FIGURE 4.3.5.1.2-3 - HYDFAULIC GRADIERT, THREE PUMPS, ALL GASOLINE 


$$
\text { Ene }
$$




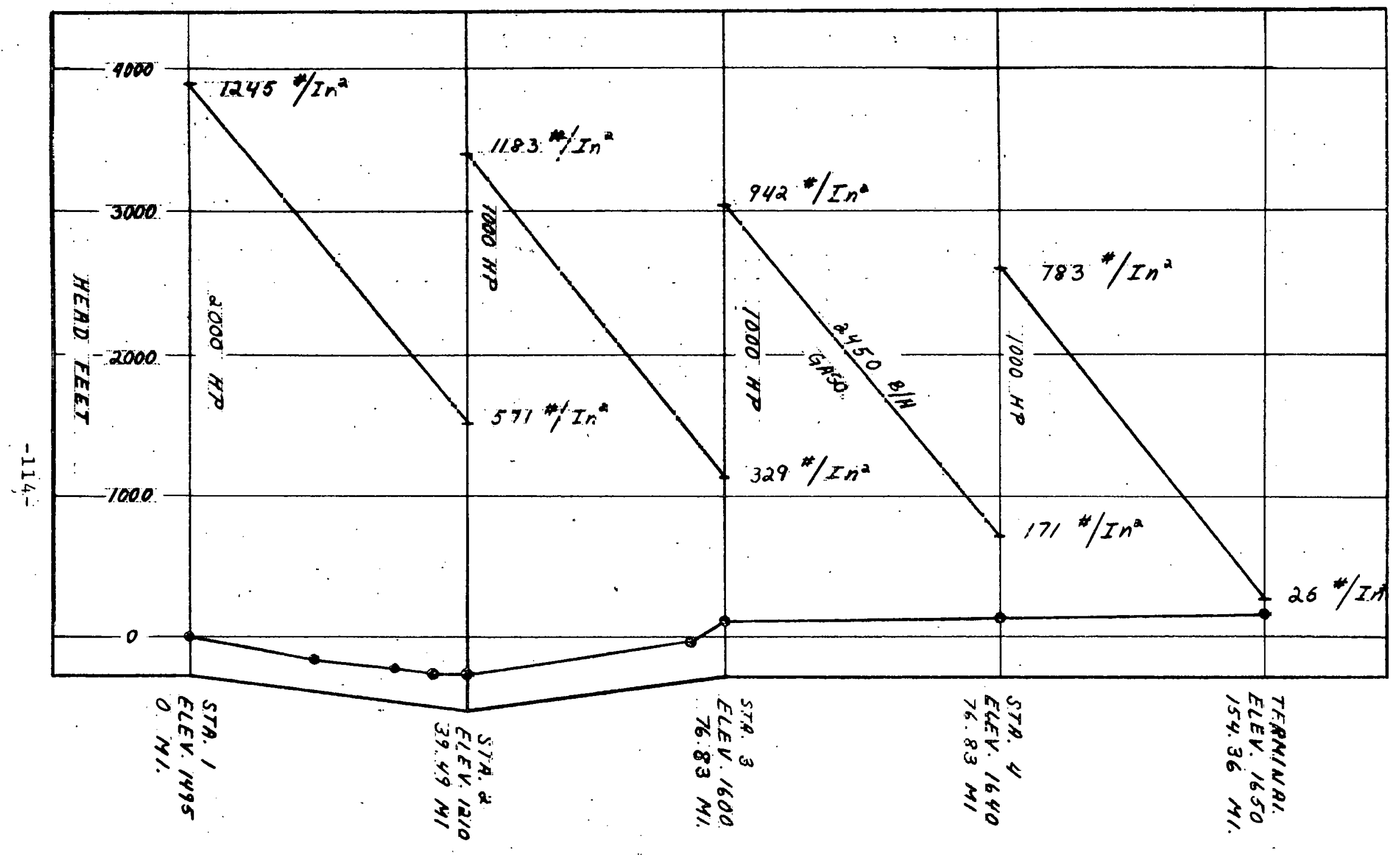
FIGURE 4.3.6.1.2-5 - HYDRAULIC GRADIENT, FIVE PUMPS, 


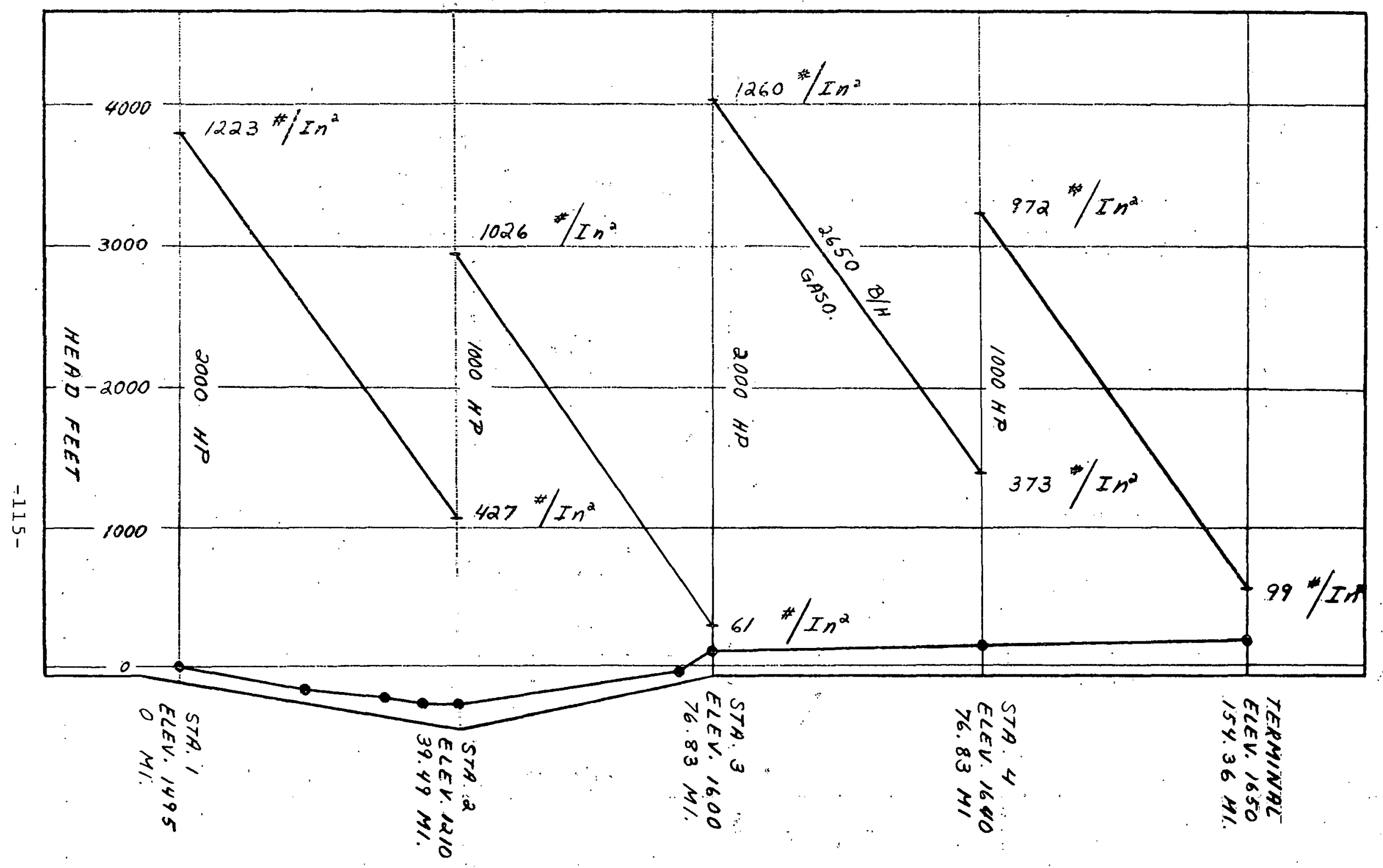

FIGURE 4.3.6.1.2-6 - HYDRAULIC GRADIENT, SIX PUMPS, ALL- GASOLINE : 


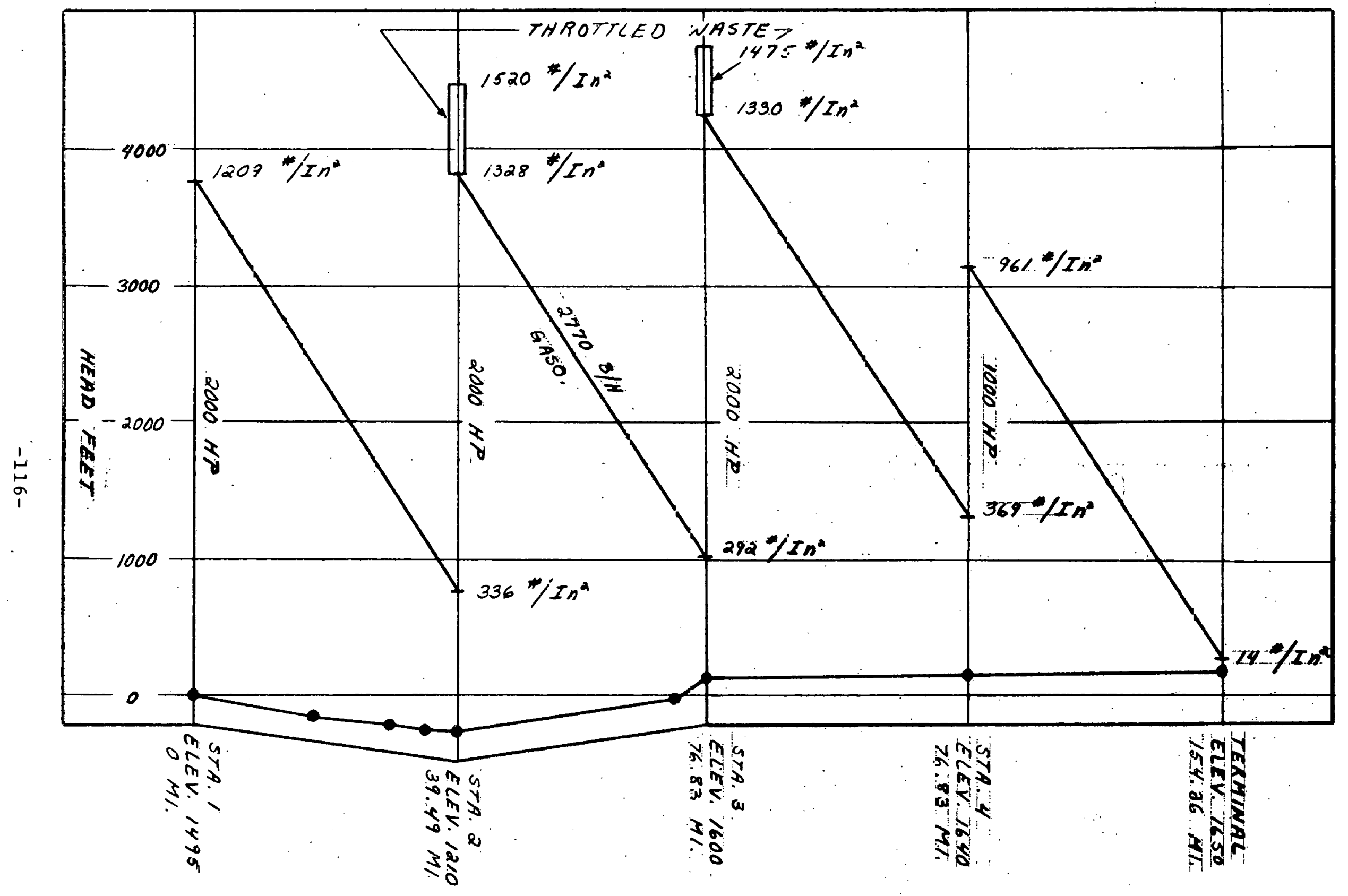

FIGURE 4.3.6.1.2-7 - HYDRAULIC GRADIENT, SEVEN PUMPS ALL. GASOLINE 


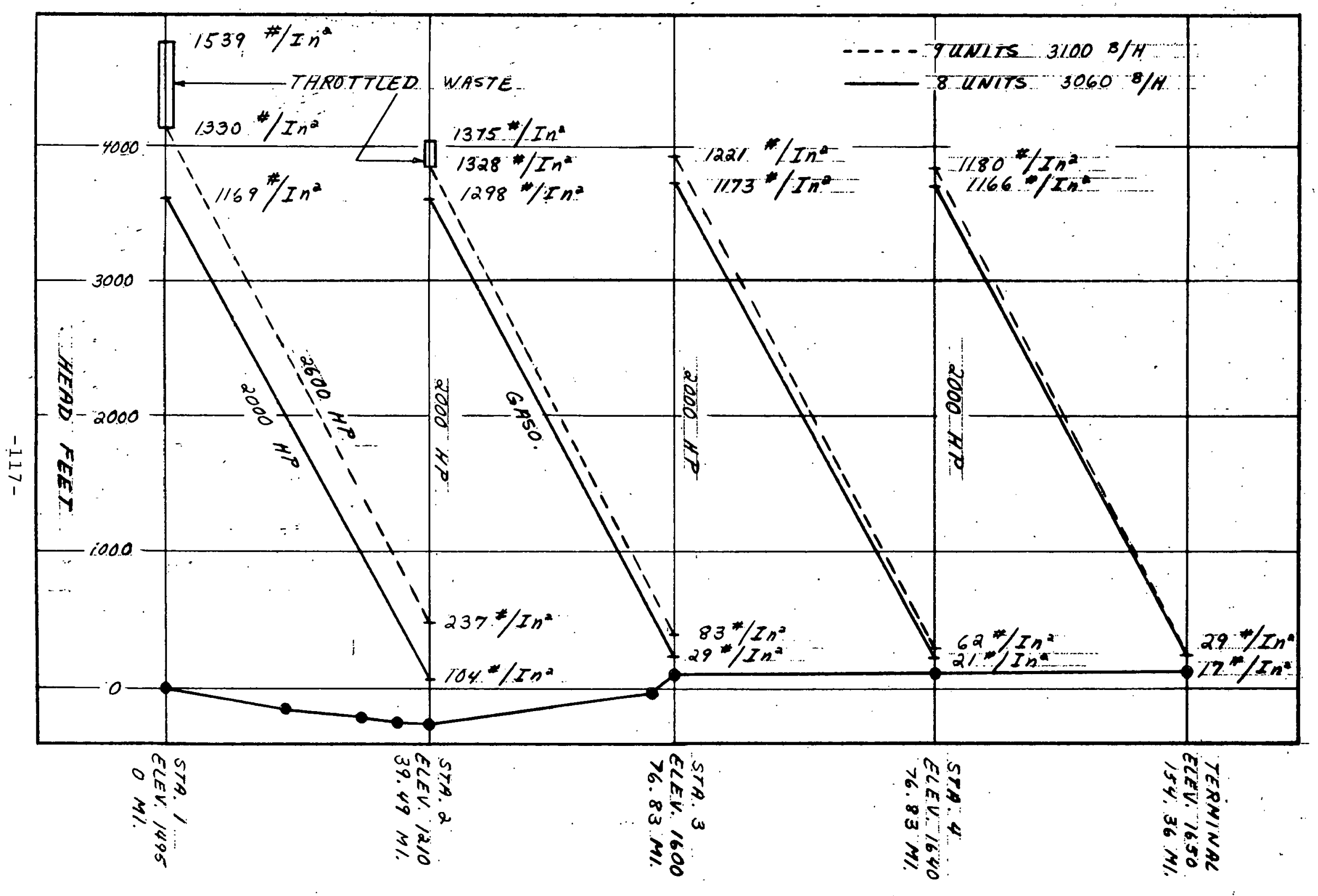

FIGURE 4.3.6.1.2-8 - HYDRAULIC GRADIENT, EIGHT/NINE PUMPS, ALL GASOLINE 


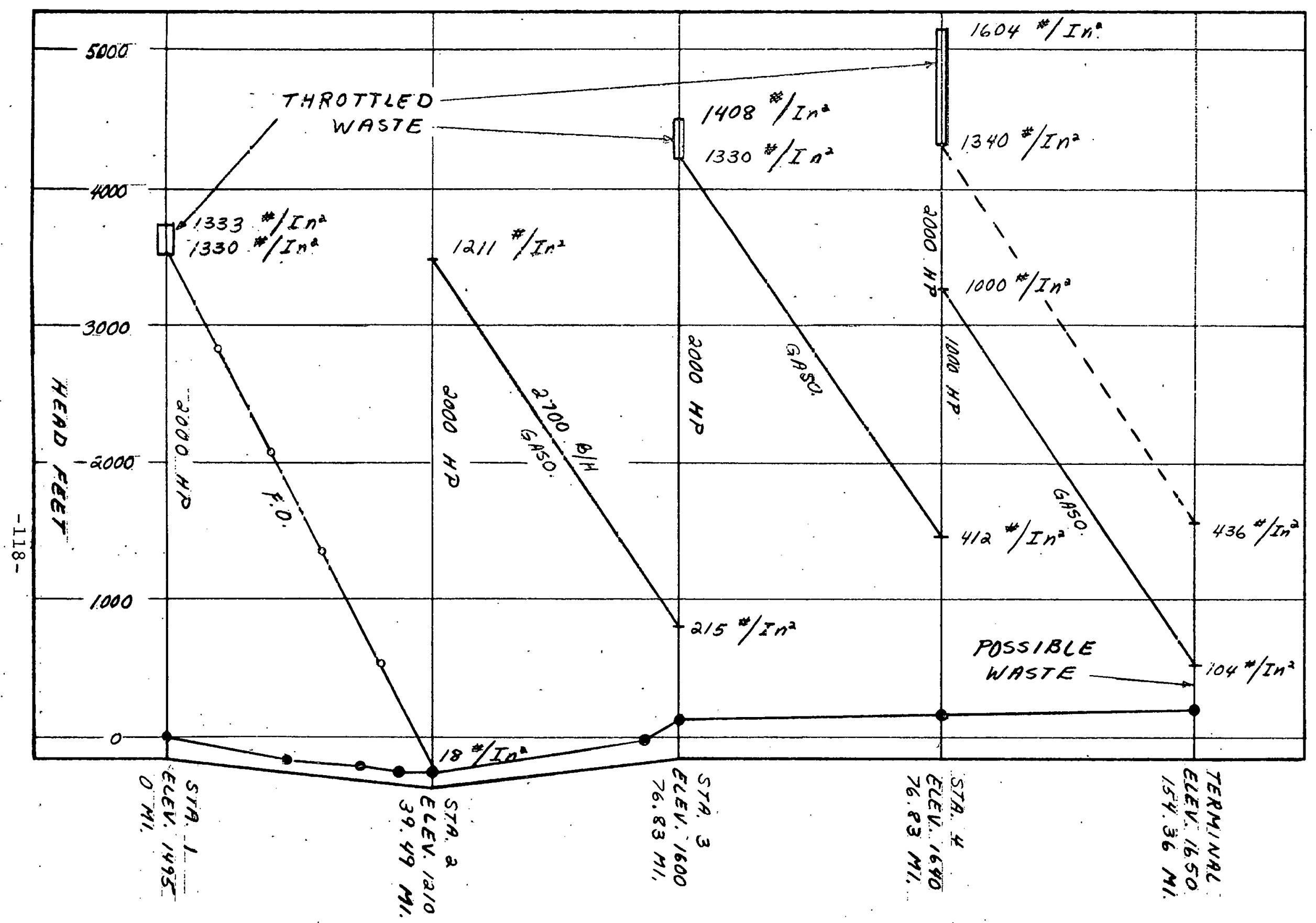

FIGURE 4.3.6.1:2-9 - HYGRAIJLIC GRADIENT, SEVEN/EIGHT PUMPS, ONE SEGMENT FUEL OIL, THREE SEGMEMTS GPSOLINE 


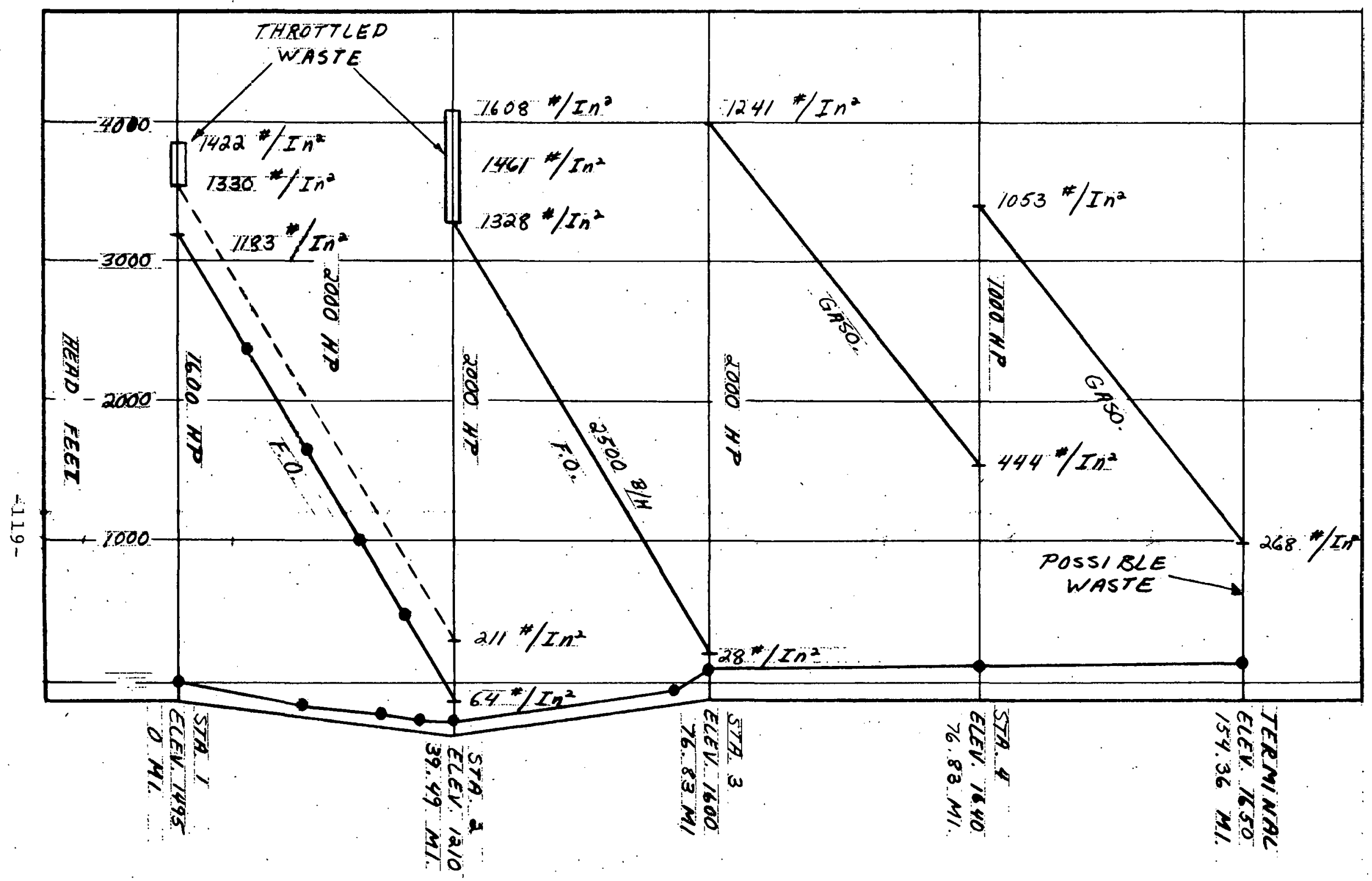
FIGURE 4.3.6.1.2-10 - HYDRAULIC GRADIENT, SEVEN PUMPS, TWO SEGMENTS
FUEL OIL, TWO SEGMENTS GASOLINE 


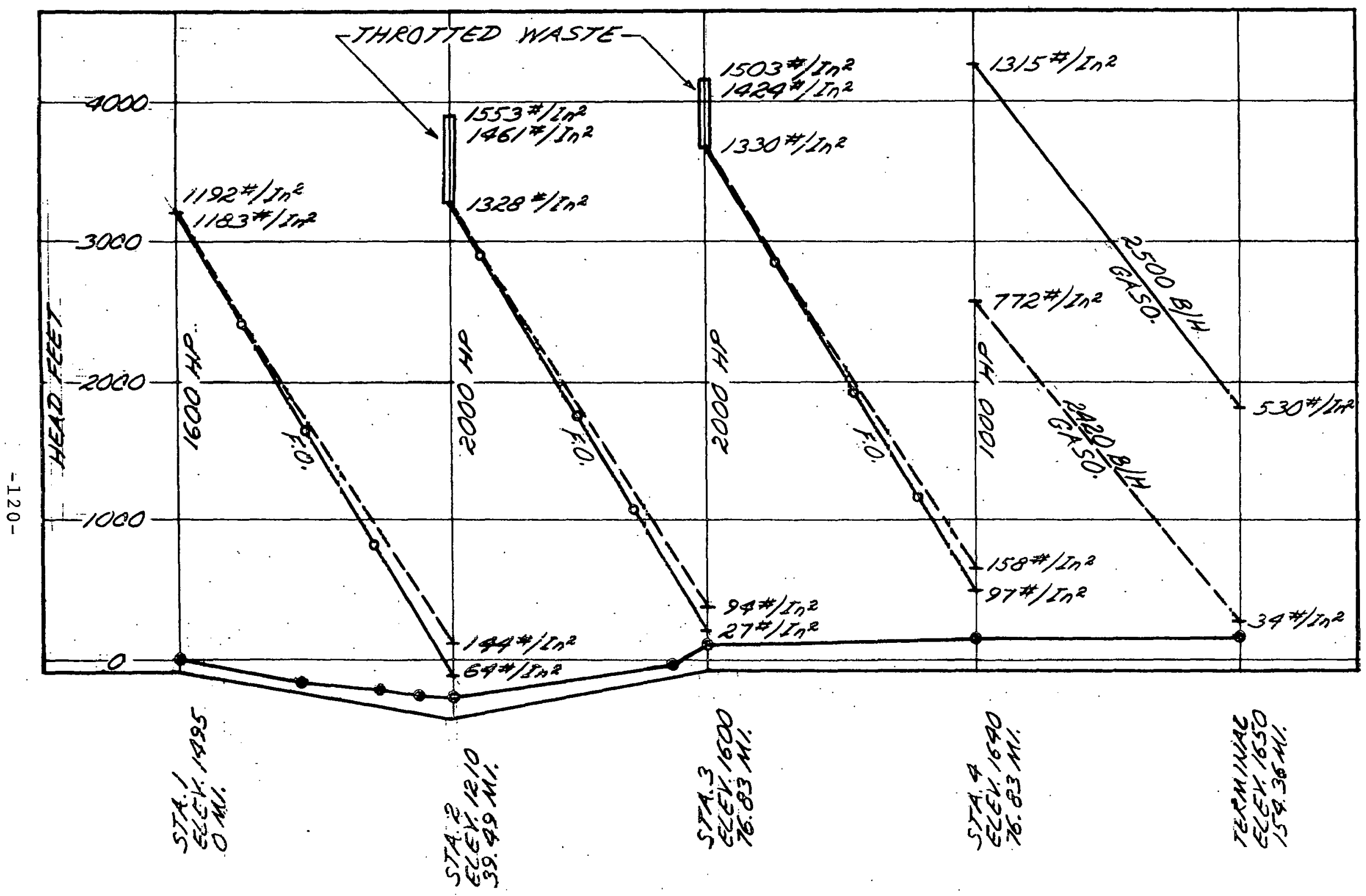

FIGURE 4.3.6.1.2-11 - HYDFAULIC GRADIENT, SE'JEN/EIGHT PUMPS, THREE SEGMENTS FUEL OIL, ONE SEGMENT GASOLINE 


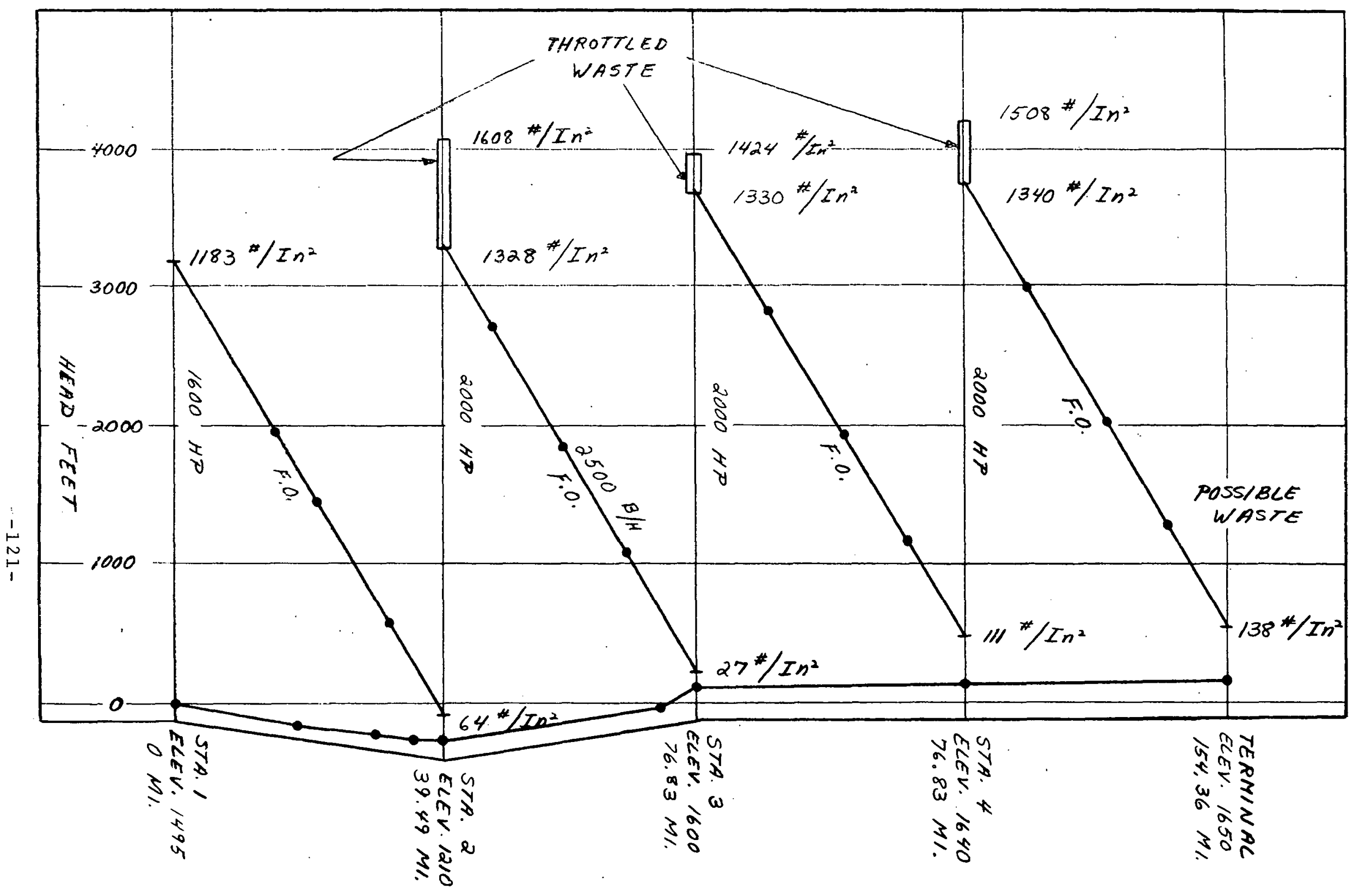

FIGURE 4.3.6.1.2-12 - HYDRAULIC GRADIENT, EIGHT PUMPS ALL FUEL OIL 


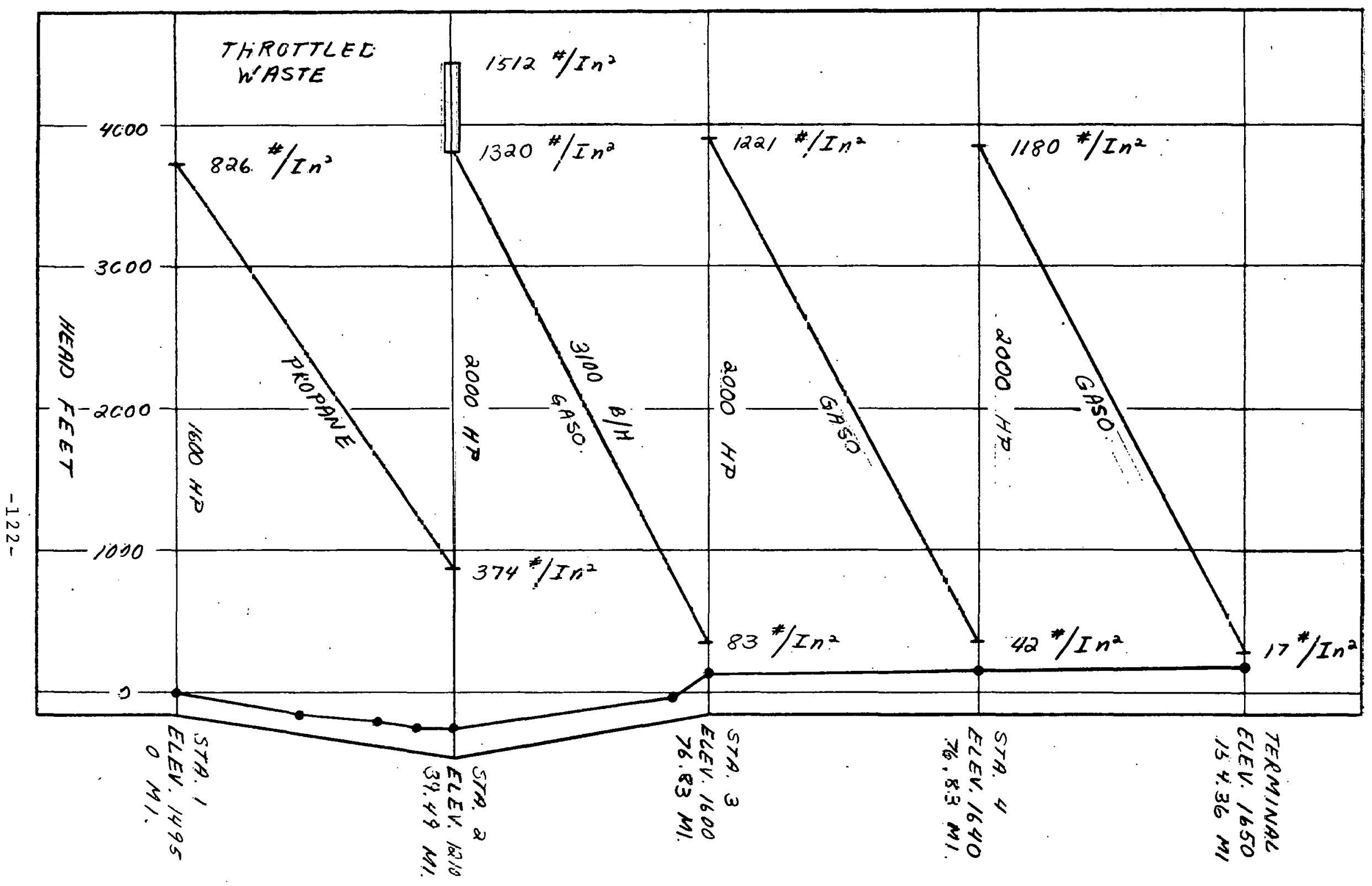

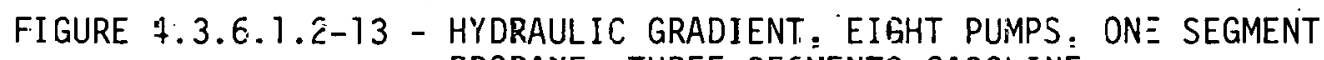
PROPANE, THREE SEGMENTS GASOLINE 


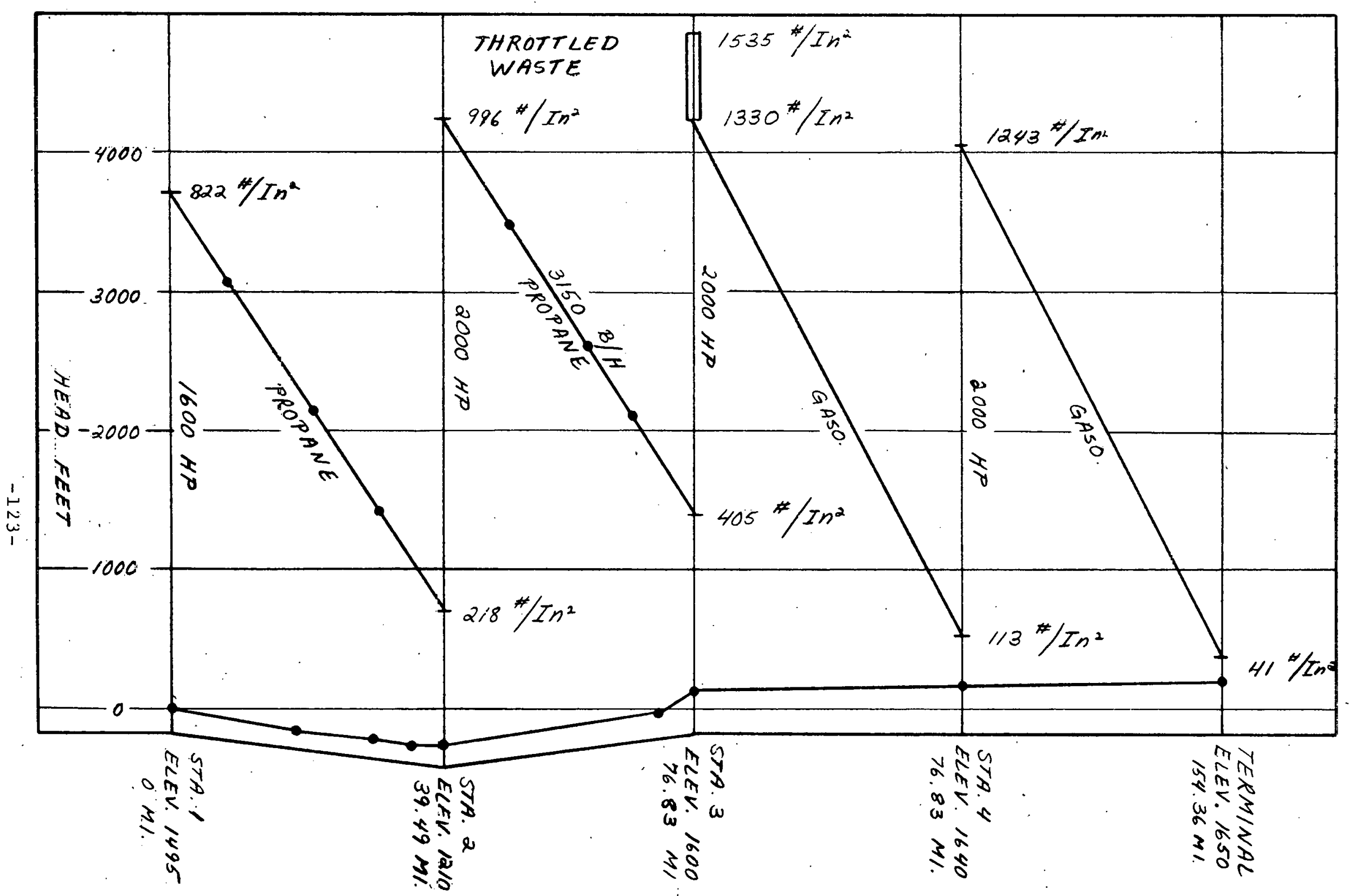
FIGUFE 4.3.6.1.2-14 - HYDRAULIC GRADIENT, EIGHT PUMPS, TWO INITIAL
SEGMENTS PROPANE, TWO SEGMENTS GASOLINE 


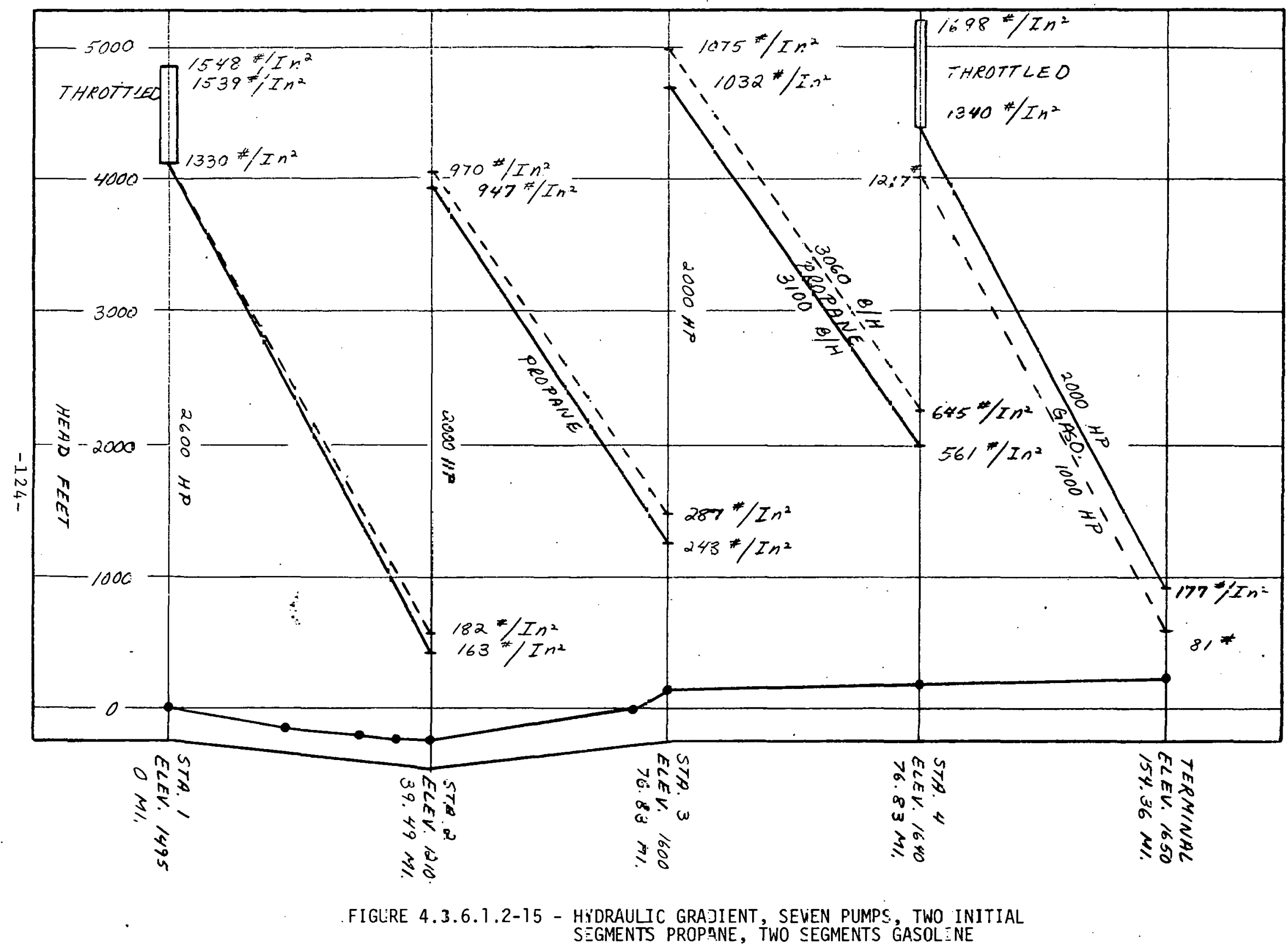




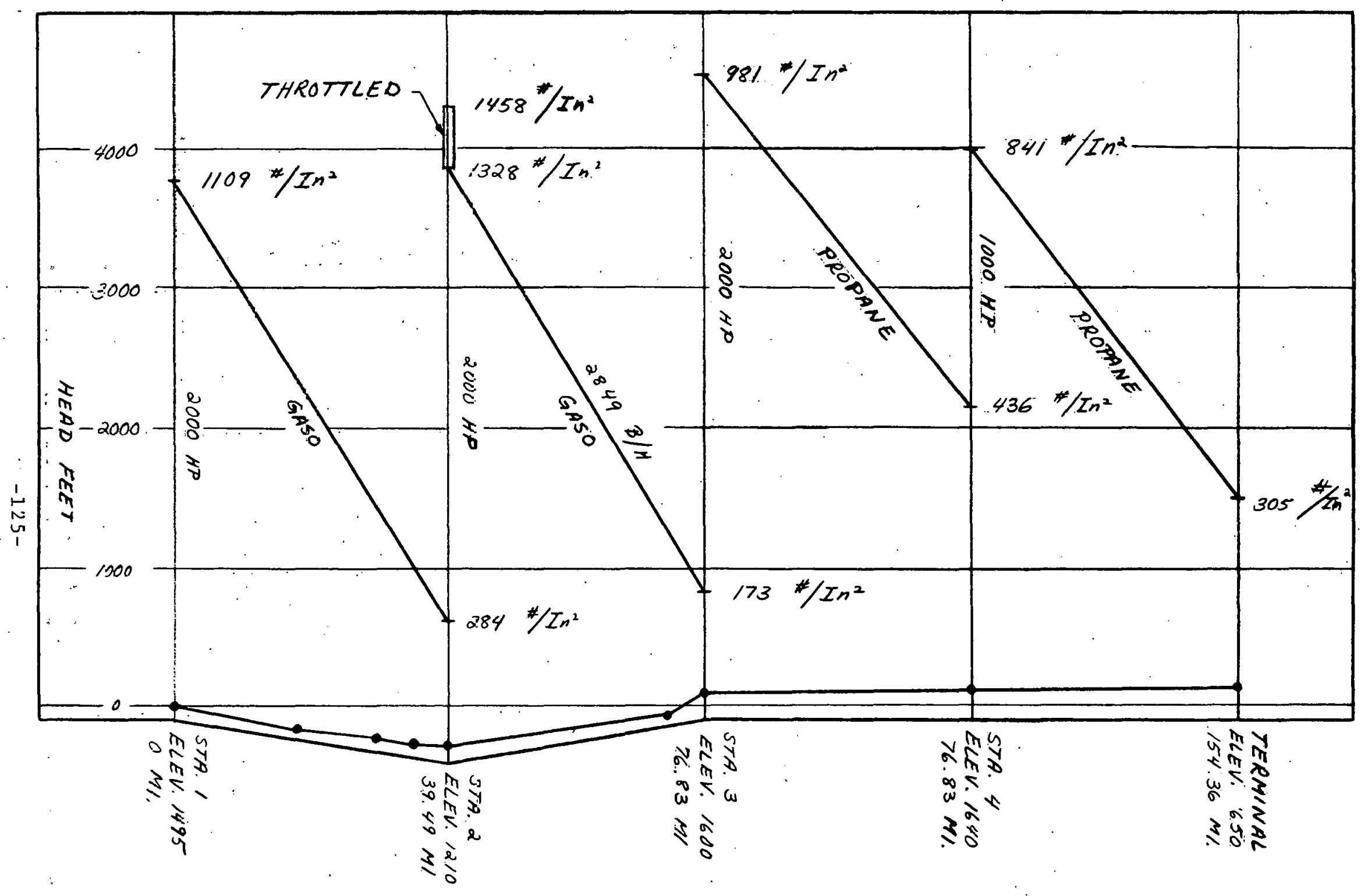

FIGURE 4.3.5.1.2-16 - HYDRAULIC GRADIENT, EIGHT/NINE PUMPS, TWO INITIAL SEGMENTS GASOLINE, TWO SEGMENTS PROPANE 


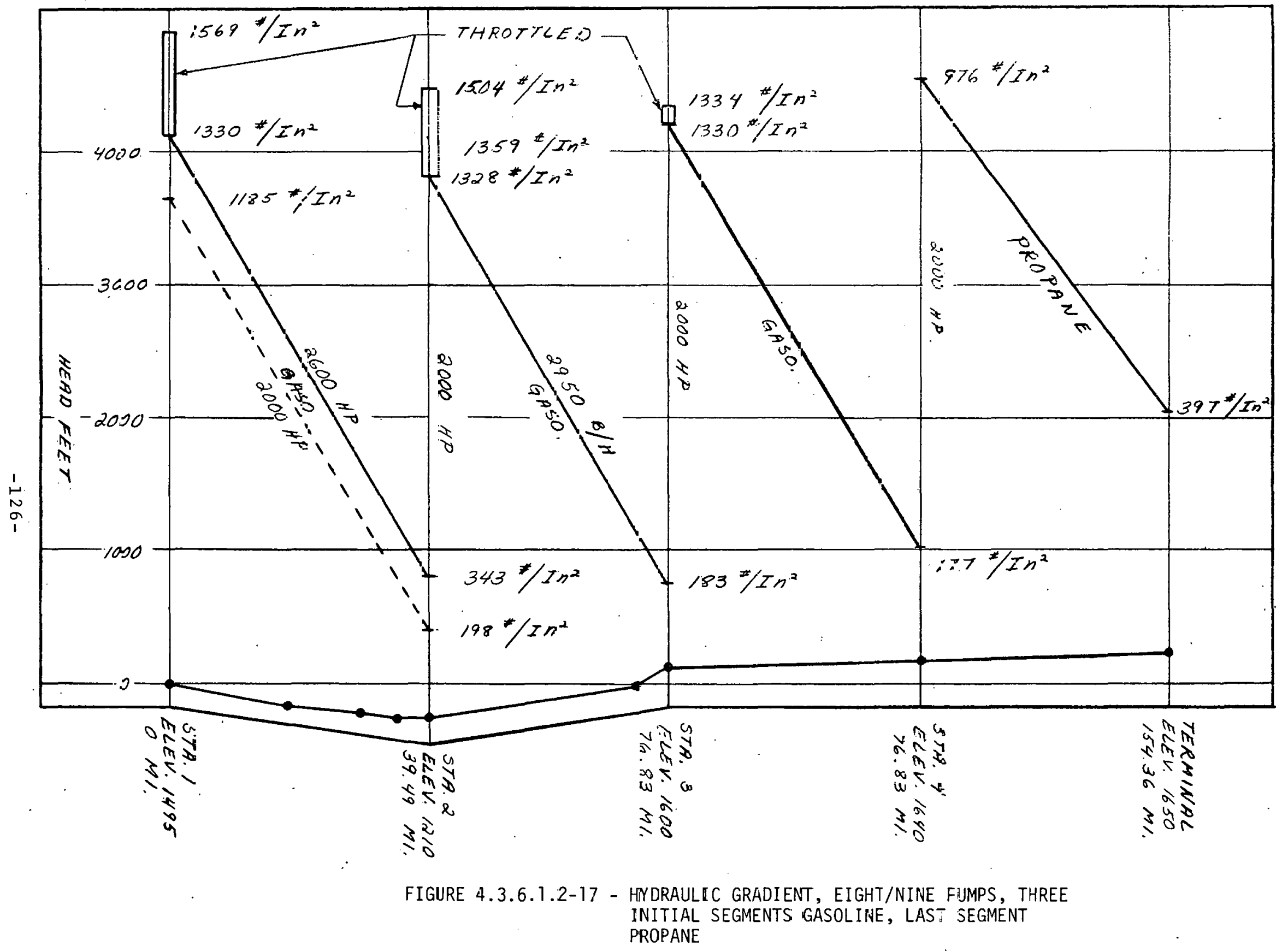




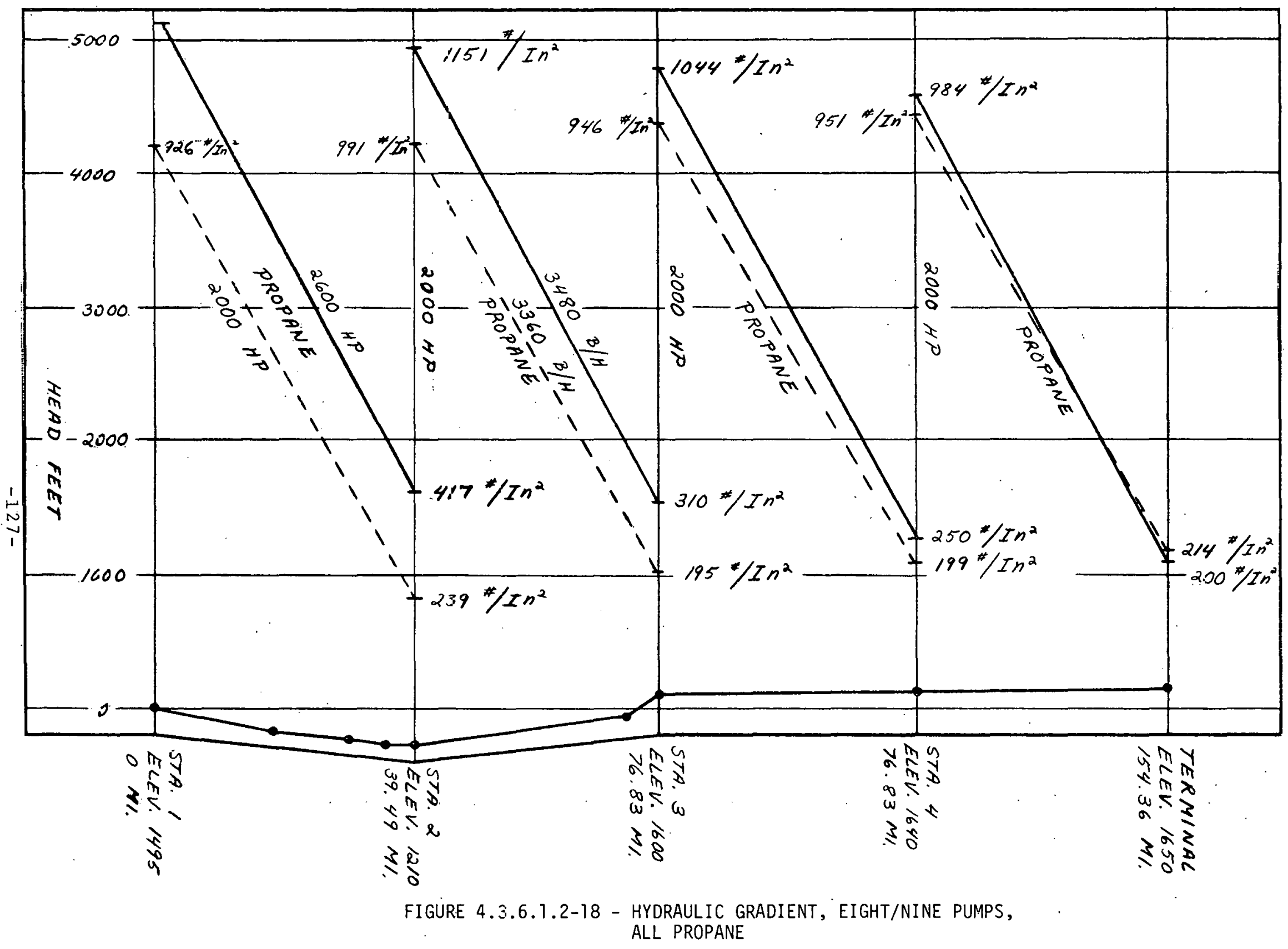




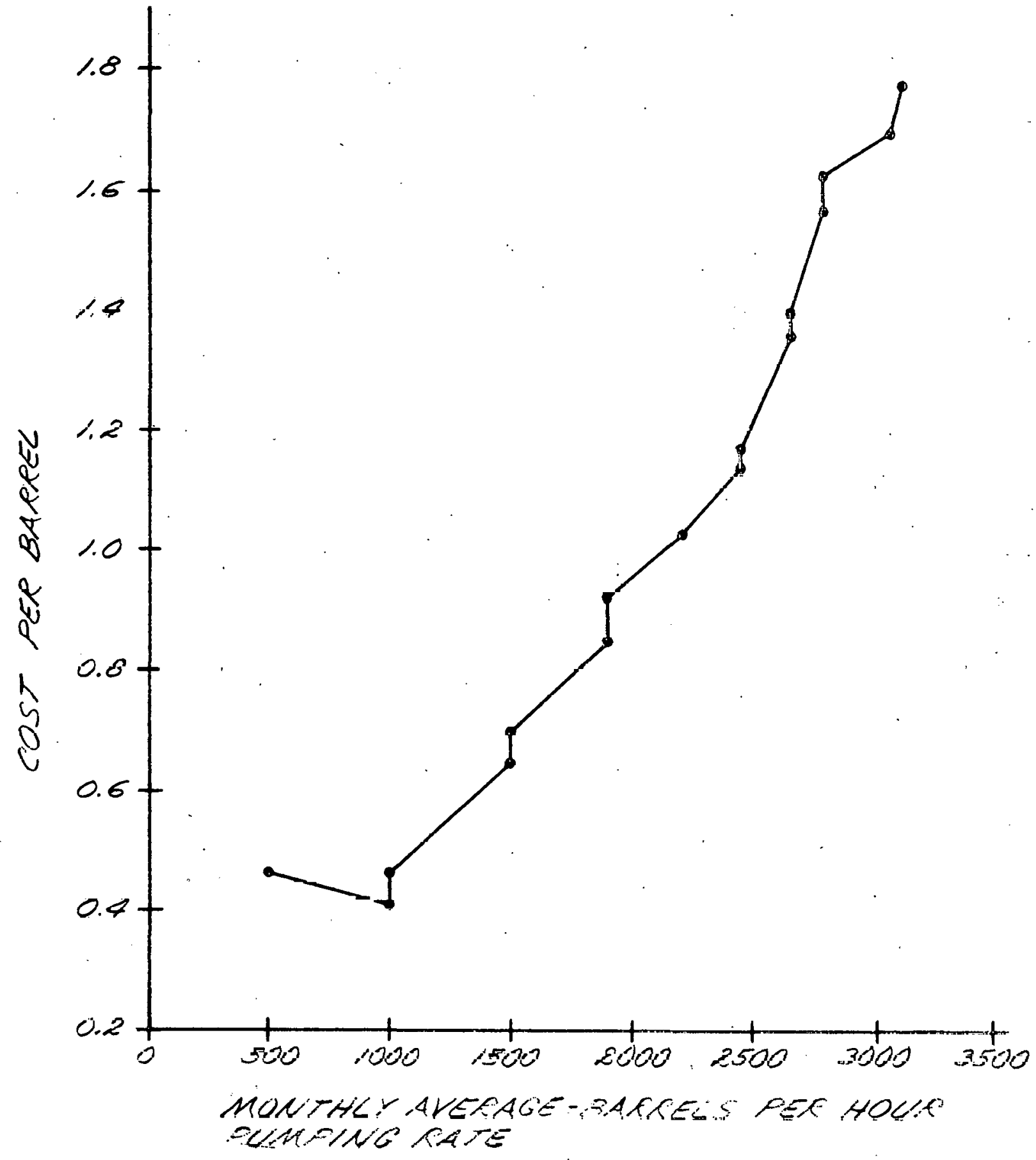

FIGURE 4.3.6.1.2-19 - POWER COST VS. THROUGHPUT 


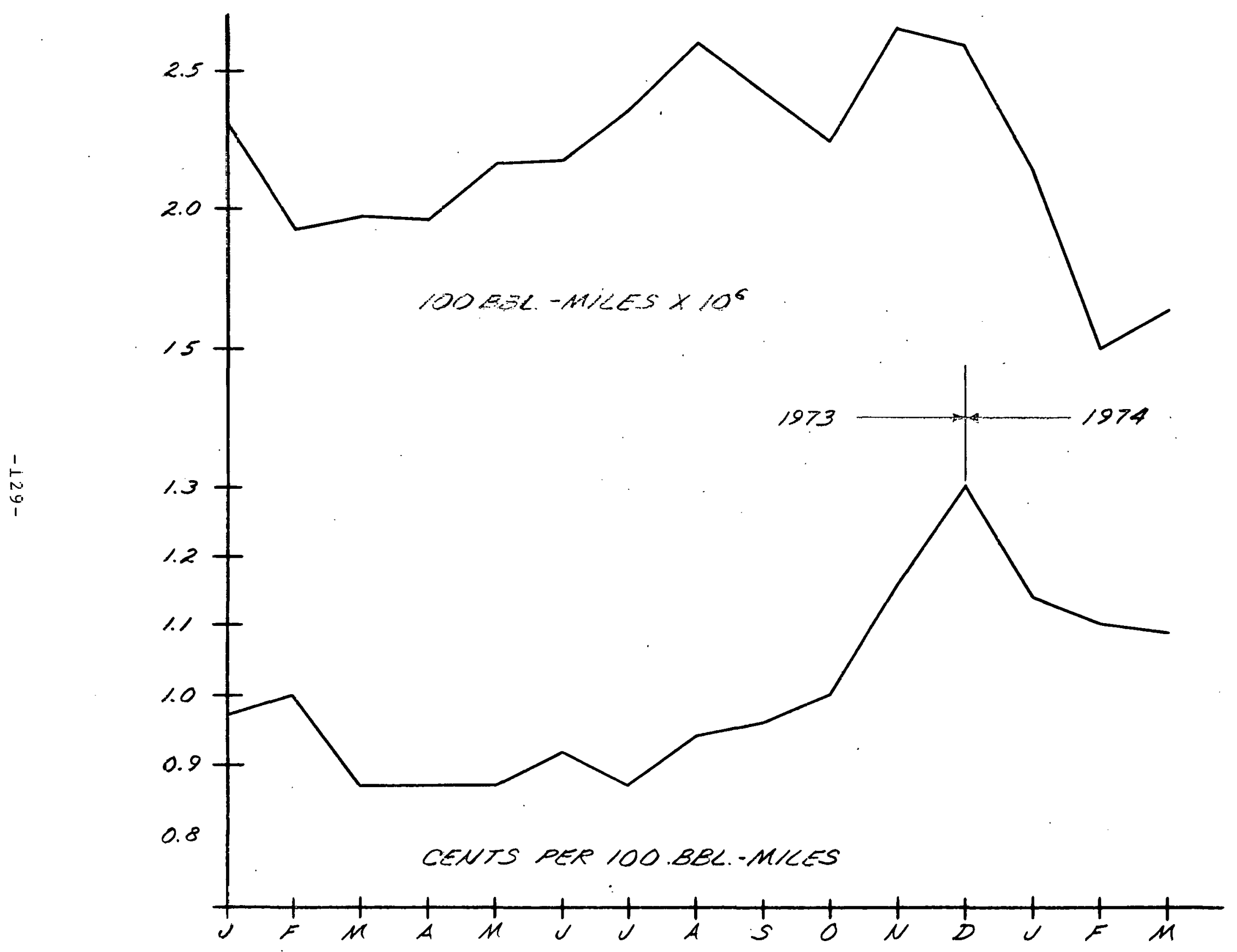

FIGURE $4 \cdot 3 \cdot 6 \cdot 1 \cdot 2 \overline{\bar{\sigma}} 20$ - UNIT ENERGY COST AND TOTAL THROUGHPUT 


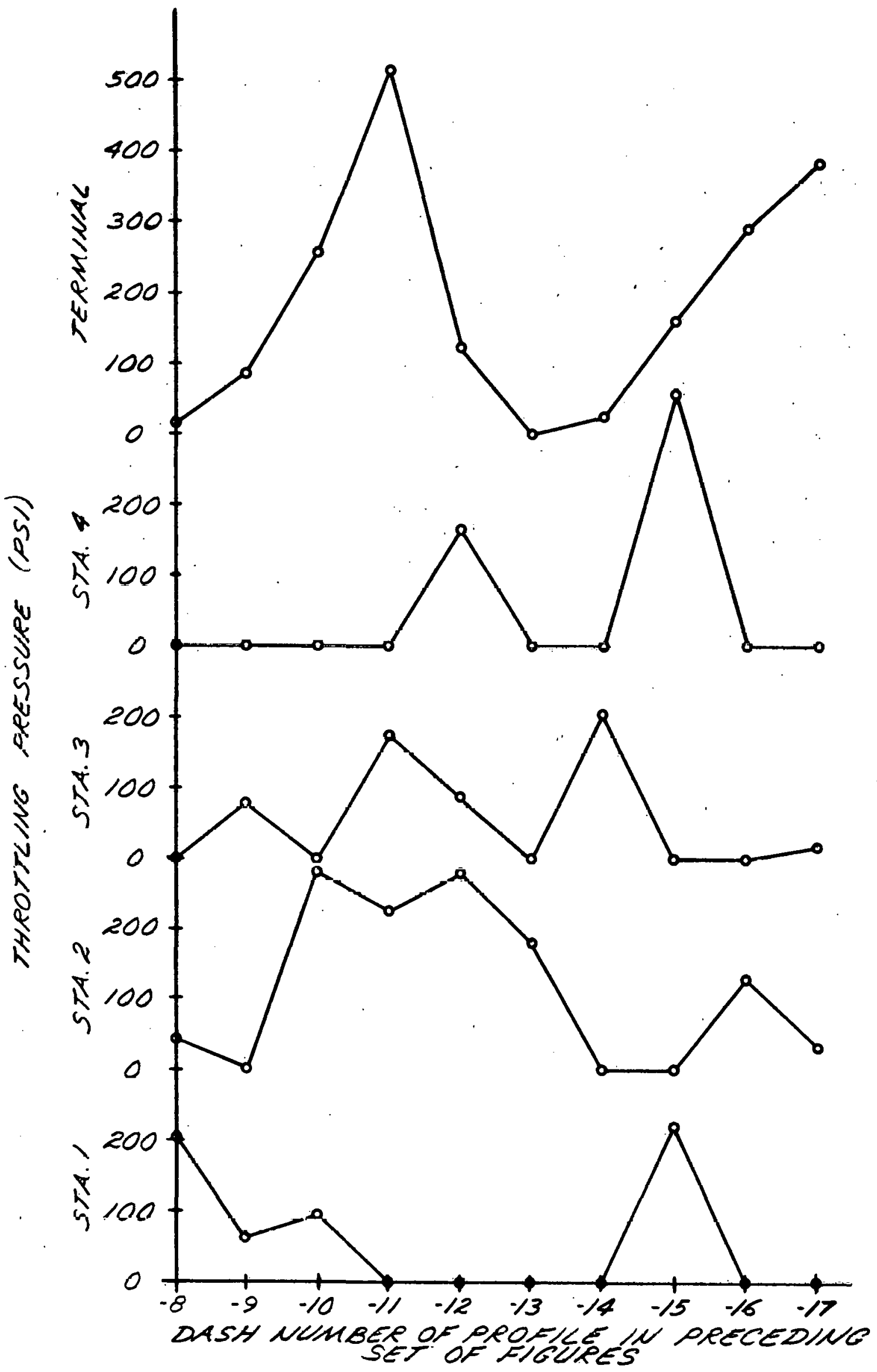

FIGURE 4.3.6.1.2-21 - THROTTLING ENERGY WASTED IN TYPICAL FULL CAPACITY PRODUCTS PIPELINE DUTY CYCLE

$-130-$ 
5.0 SLURRY SYSTEM IMPROVEMENTS

5.1 Technological Status of Coal slurry Pipelines

The technology of coal slurry pipelines is solidly established. Slurry pipelines first gained recognition as a viable method of transporting solids in 1957 when the 108-mile Consolidation coal pipeline entered service in Ohio, with a capacity of 1.3 million tons/year. This slurry line moved 7 million tons of coal from 1957 to 1963, when it closed down, not because of technical problems, but because of rail rate reductions for large tonnages. The economic and political forces involved have been examined under Task 2 of this project, and are discussed in section 4.2.1 of Reference 24 .

The longest and largest slurry system yet built is the Black Mesa line. The history and description of the line have been presented (Ref. 25) and updated (Ref. 26), and are summarized below.

Black Mesa Pipeline, Inc., was organized in 1966 to construct, own, and operate a coal slurry line connecting the Black Mesa, Arizona, coal field to the proposed Mohave Generating station in southern Nevada, over the route shown in Fig. 5.1-1. Black Mesa Pipeline, Inc. is a wholly owned subsidiary of Southern Pacific Pipe Lines, which operate 2400 miles of petroleum products pipelines. These pipeline systems in turn are a part of Southern Pacific Company. This is the longest and largest slurry line yet built. In 1967, a 35-year transportation contract was signed with Peabody Coal Company and engineering design began. Shakedown began in August 1970, and by November, commercial operation was in process.

Black Mesa Pipeline receives coal at a central point in Peabody's strip mine located on the Black Mesa of the Navajo 


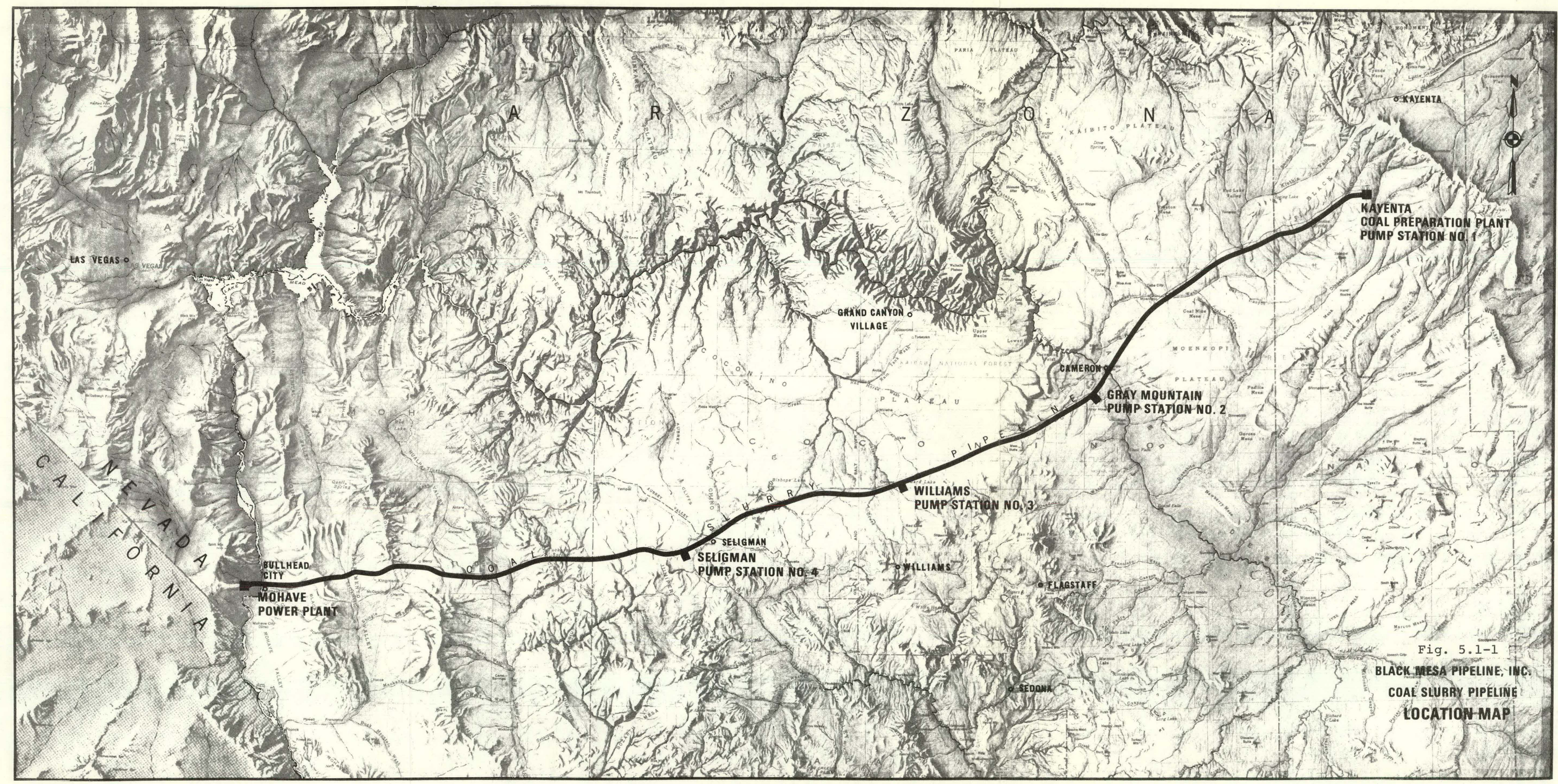


and Hopi Reservations in northeastern Arizona. The pipeline system includes slurry preparation plant, pump stations, pipeline, test loops, control and communication facilities, but not terminal storage and dewatering facilities, which are part of the power plant (Fig. 5.1-2). Slurry process water is furnished by the coal company from deep wells. The Black Mesa system cost approximately $\$ 39$ million.

Coal is received from the coal company at the preparation plant by a conveyor belt, which delivers $2 " \mathrm{x} 0$ " coal into three elevated raw coal bins. Each bin feeds a process line consisting of an impact crusher, a rod mill, a sump and centrifugal sump pump, shown in Fig. 5.1-3. Impactors reduce the coal to $1 / 4 " \mathrm{x} 0$ " by dry crushing, and rod mills pulverize the coal.by wet grinding to 8 mesh $\times 0$. Slurry is formed in the rod mills, where water is introduced. From rod mill, sump slurry is pumped into one of four 630,000 -gallon storage tanks, which are open top and equipped with mechanical agitators to maintain slurry suspension. The slurry is transferred from the storage tanks by a centrifugal charge pump into the suction of the mainline high-pressure pumps.

The pipeline system is capable of pumping 660 tons of coal per hour. At $48 \%$ solids by weight, flow is $4200 \mathrm{GPM}$ and velocity is $5.8 \mathrm{fps}$. When lower delivery rates are required, flow is reduced, down to about $5 \mathrm{fps}$. Any necessary further reduction is accomplished by inserting water slugs between batches of slurry. Transit time is three days, and line fill includes 45,000 tons of coal.

Four pump stations are required. These are sizeable installations, utilizing the largest piston pumps with electric motor drives and hydraulic couplings for speed control. Three stations have three pumping units installed, with one a spare. The fourth station has four units, with a spare. The three-unit stations operate at about 1000 psi, and the four- 


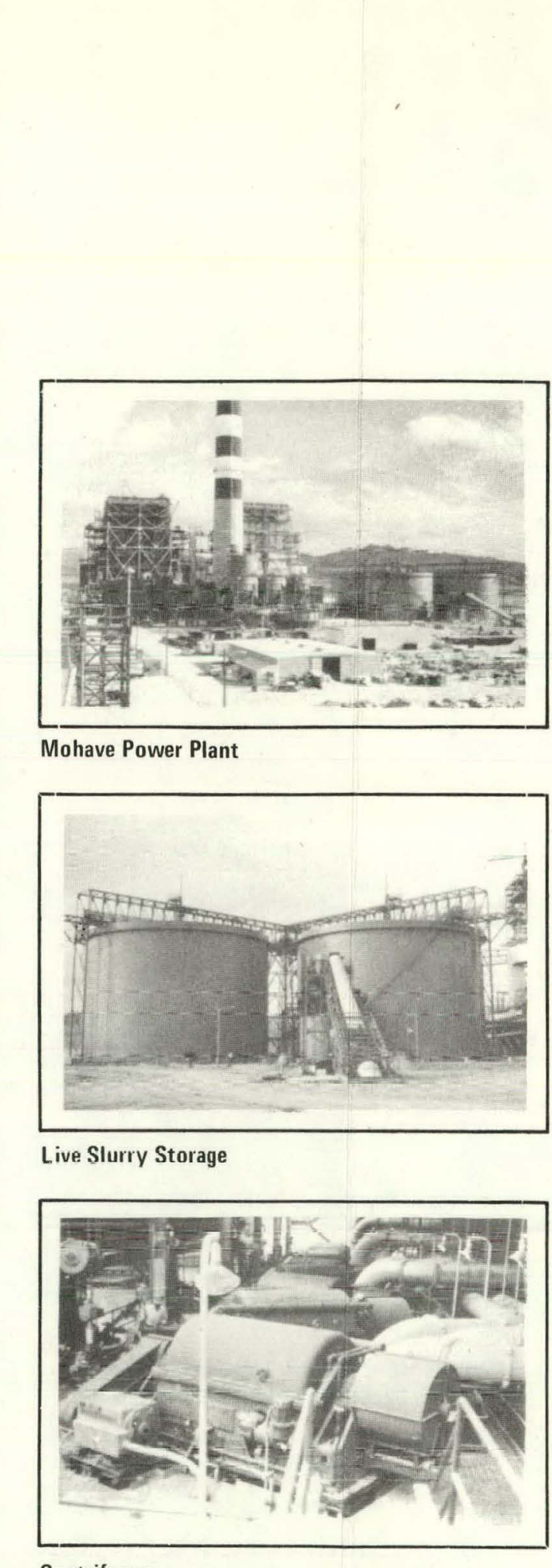

Centrifuges

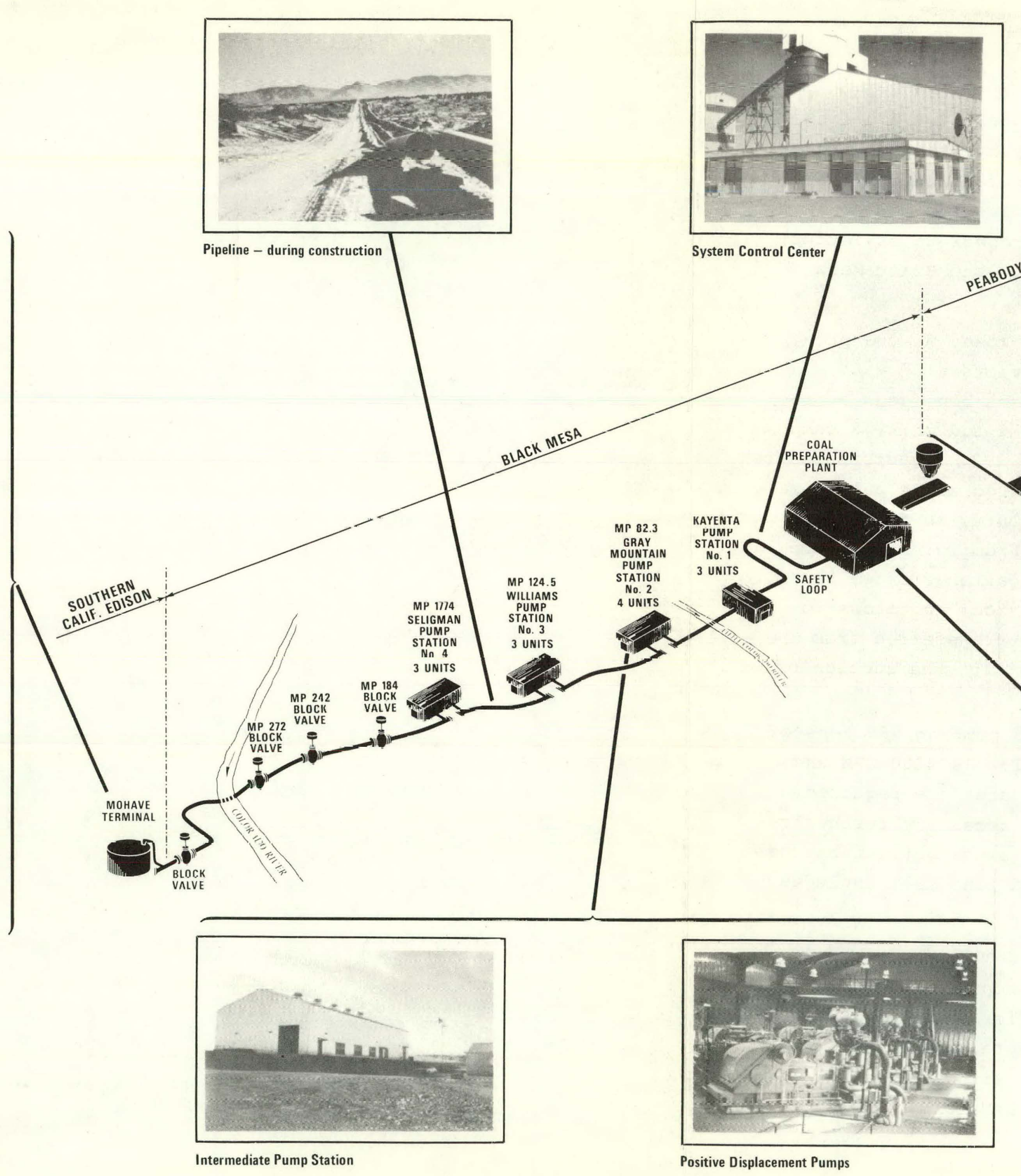

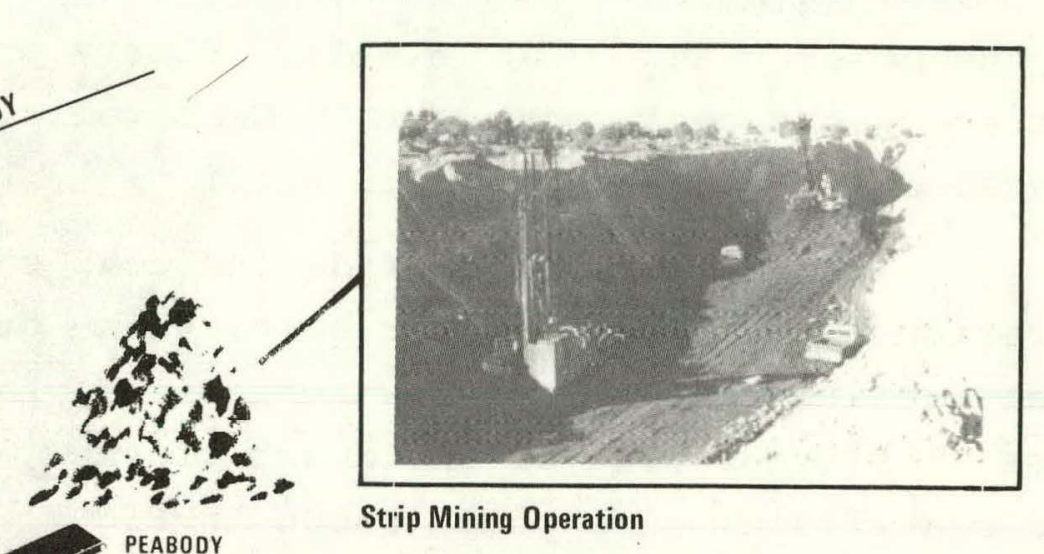

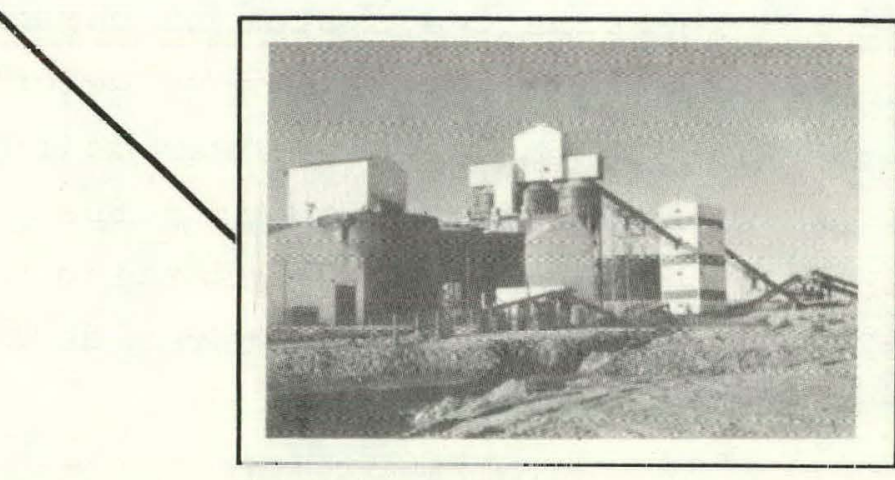

Slurry Preparation Plant

Fig. 5.1-2

BLACK MESA PIPELINE, INC. COAL SLURRY PIPELINE SYSTEM 


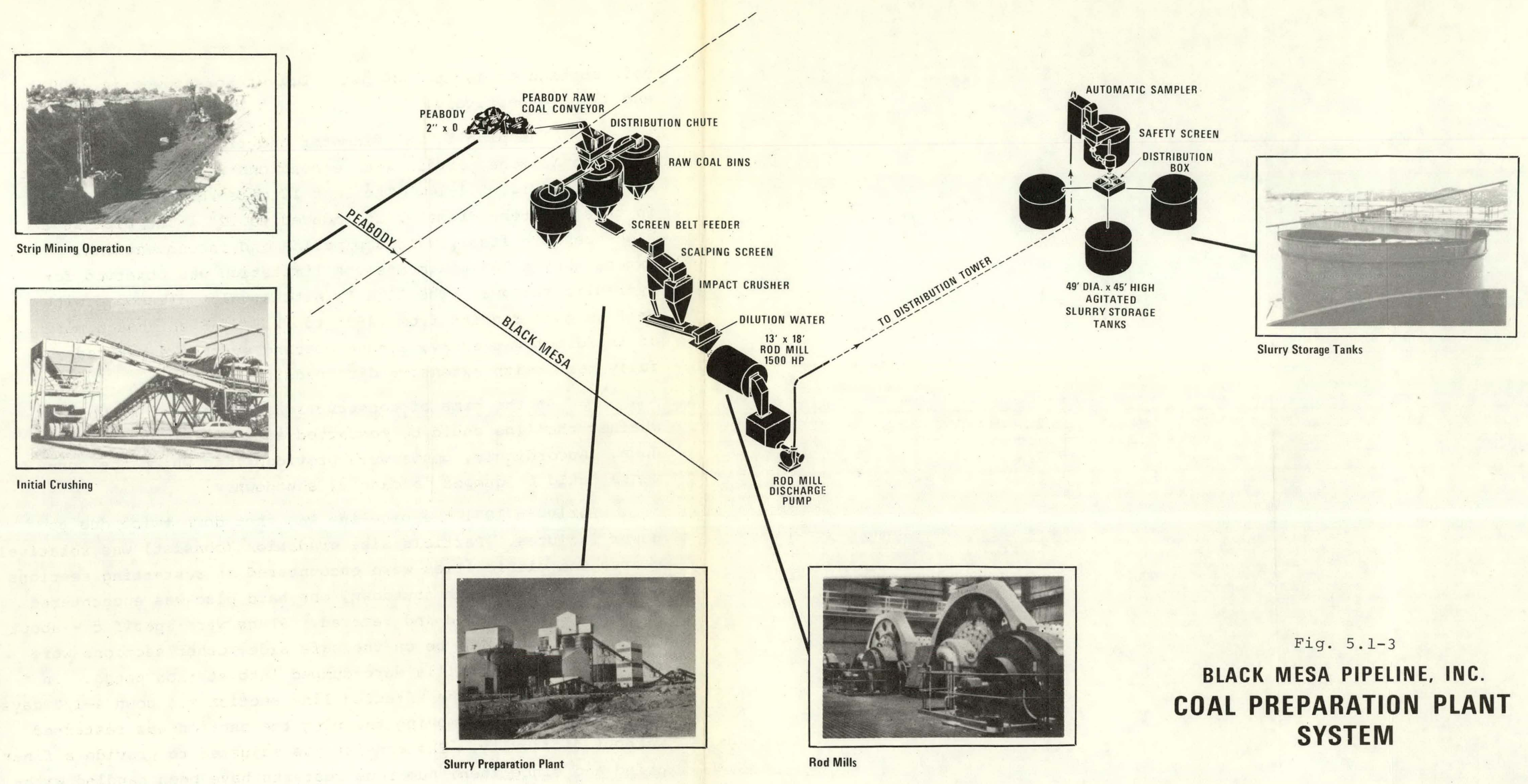


unit station at about 1500 psi. Driver horsepower is 1500 and 1750 respectively.

The pipe is 18" diameter and traverses mountainous northern Arizona terrain with elevations varying from $6500 \mathrm{ft}$ to $500 \mathrm{ft}$ (Fig. 5.1-1). The last 12 miles drop $3000 \mathrm{ft}$ and in this stretch, diameter is reduced to $12 "$. The pipe is a high-pressure steel, welded pipeline and is conventional except that a $16 \%$ maximum slope limitation was observed for hydraulic reasons. The line is extensively telescoped with wall weights ranging from .469" to .219". Even though most of the ditch was rocky, a tape coating system was successfully used, with extensive dirt pading.

At the time of construction, it was not known whether the line could be restarted afler dn extenced shutdown. Accordingly, ponds were provided into which the contents could be dumped in case of shutdown.

Early in 1971 the pipeline was slut duwn twice due to power failures. Particle size gradation (consist) was relatively coarse and difficulties were encountered in restarting sections of the line. On each shutdown, onc hard plug was encounlered and had to be located and removed. Plugs were sperifir - about 40 -tt in length. To be on the safe side, other sections were restarted and line fills were dumped into station ponds. In the first instance the affected line section was down $41 / 2$ days, but subsequent to removing the plug the section was restarted without difficulty. The consist was adjusted to provide a finer grind and since then, numerous restarts have been handled without difficulty. It is not expected that extensive dumpiny will occur again. The two important keys to a restartable slurry are a fine grind and a well-graded consist. 
Pump stations and pipeline operation are supervised from origin point. Stations, which are complex, are operated unattended; however, there are two resident employees at each booster station to perform maintenance and to provide on-call availability. Pumping is "tight-lined," i.e., without surge tankage at booster stations, Locations are linked by a solid state, hot, standby, microwave system operating at $2100 \mathrm{MHz}$. One link of $109 \mathrm{miles}$ involves use of space diversity antennas to cope with atmospheric fades.

The slurry is delivered at the power plant into large $(7,800,000$ gallon) storage tanks. The tanks, with 500-hp agitators, though much larger than any such tanks previously built, have operated satisfactorily. Slurry is withdrawn from tankage by a centrifugal pump and transferred to a battery of 40 centrifuges, where $65 \%$ of the water is removed. The resulting wet cake is conveyed to 20 bowl mills for drying and further pulverizing. Dried coal is carried pneumatically to the combustion chambers.

Fifty-two permanent employees are required to operate the pipeline. Of these, about 36 are at the Black Mesa preparation plant. The remainder are technical and administrative personnel located in Flagstaff and at the booster stations. At Black Mesa, Navajo and Hopi Indians are given employment preference under terms of the mining lease. At both Peabody and Black Mesa Pipeline, Indian personnel are in the majority.

The system is operated by a four-man shift at Black Mesa. The group includes a Shift Supervisor, a Pipeline operator in the System Control Room, and Operator-Repairman handling preparation plant and other facilities, and an Operator-Repairman Assistant primarily doing slurry quality control testing in the Testing Laboratory.

It has been noted earlier that pipelining solids requires considerable testing to determine minimum operating velocitieswith respect to deposition or bedding and to assure good restart characteristics. Varying the percent solids and the size consist affects these important operating characteristics. High capacity 
test loops are useful here, and Black Mesa has several well instrumented loops, including one 1000' long and 24" in diameter. After determining the desired specification, it is necessary to monitor carefully to assure that specification is consistently met. Percent. solids or density is extremely important and is monitored by a nuclear density meter mounted outside the pipe. Size consist must be laboriously obtained by sieve analysis run every hour or two.

The slurry is sometimes corrosive and requires the addition of some inhibitor. Water batches especially require use of an inhibitor. Careful corrosion monitoring is necessary.

While the pipeline can be shut down and slurry allowed to settle, pump cylinders and valve chambers as well as convolved station piping must be promptly flushed upon shutdown. The siurry tends to pack into dead spots except for those on top of the pipe, which affects valve selection. A conventional gate valve will not function well in slurry service. Ball valves and lubricated plug valves seem best suited for slurry.

Wear is a continuing process in the mainline pumps. It is of course to be expected, and is therefore not a problem. Valves, seats, pistons, rods, and packing are expendable. However, these parts have met and, in most cases, exceeded expected service life.

The system has successfully completed more than six years of operation. While the line is capable of transporting over 5 million tons of coal per year, it has actually averages only about 4 million tons per year because of lesser burn requirements at the power plant. Plpeline availability, has exceeded 99\%. The plant engineer at the Mohave Generating Station reports that, of the three major subsystems, coal mine, pipeline, and power plant, virtually all system downtime is due to either the mine or the power station. The pipeline "is always running." 
Because minimum operating velocity and design through-put velocity are fairly close together, the pipeline has a relatively small turndown. When the power plant requirement is less than pipeline turndown, batching is necessary and a dispatching model has been just as useful in this application as on a petroleum line. Flow is measured in gallons per minute using magnetic flow meters and by timed stroke counts. Gallons per minute and tons per hour are related by specific gravity of solids and percent solids.

In closing, it is well to mention planned future systems. The line that is in the most advanced planning stage appears to be the 1036-mile pipeline of Energy Transportation Systems, Inc. (ETSI), owned by Bechtel, Lehman Bros., and the Kansas Nebraska Natural Gas Co. The proposal to build this billion-dollar line has evoked strong opposition (Ref. 24). An indeterminant period of time may be required to resolve the contested issues. A study by the OTA, scheduled for completion in mid-1977, will cover technological, energy, and legal issues; environmental effects (especially water and land use); evaluation of costs and returns; and impact on the railroads.

5.2 Methanol-Coal Slurries

A promising new concept in coal slurry technology which appears to have potential for overcoming some of the problems and limitations associated with coal-water slurries is the methanolcoal slurry system. Leonard Keller, President of the Methacoal Corporation, Dallas, Texas, holds patents (Ref. 27) relating to the methanol-coal slurry, which he calls Methacoal. He describes Methacoal as a pseudo-thixotropic, or shear-thinning, mechanically stabilized suspensoid. At rest it appears to be a moist, solid mass of black mud, but when subjected to stirring or agitation, it becomes thinner and flows easily. The flow characteristics are such that it is typified by viscous or laminar flow, rather than the turbulent flow characteristics typical of coal-water slurries. 


\subsubsection{Methanol Carrying Capacity}

5.2.1.1 Experimental Measurements of Carrying Capacity

It appears that methanol has somewhat greater carrying capacity than water. To acquire some first-order verification of this hypothesis, as a part of this project rheology tests were conducted under subcontract by Prof. R. R. Faddick of the Colorado School of Mines. His report is condensed and summarized below.

In conjunction with rheological tests, additional bench tests are necessary to determine solids specific gravity, solids screen analysis, density and viscosity of the liquid carrier and, where coal is concerned, a proximate analysis. A Western coal was selected for which all this information was readily available. A relatively fresh, unused sample of Utah coal was available in the Rheology Lab from a previous study.

Three concentrations of coal, from maximum possible down to $-5 \%,-10 \%$ from maximum were studied at room temperature. Commercially available methanol was used with one particle size distribution of coal.

Rheology is the science of the flow deformation of liquidlike substances subjected to shearing stresses. These stresses are measured over a range of shearing rates. The resulting relationship of shear stress vs. shear rate depicts the flow deformation characteristics of the slurry for a specific solids concentration, size distribution, and temperature. These data, when plotted, form the slurry rheoqram. The slope of the rheogram is called the dynamic, or absolute, viscosity of the slurry.

Newtonian liquids, such as water and most hydrocarbons, bear a linear shear stress-shear rate relationship, the slope of which is a constant. The deviation of the slurry rheograms from linearity is a measure of their non-Newtonian characteristics or variation in viscosity with shearing rate. Translated to pipeline flow, this means that the viscosity of the slurry varies with the flow and is not a constant as it would be for a Newtonian liquid. 
The purpose of the rheology measurements, then, is to determine a slurry's shear stress-shear rate relationship. A mathematical model. of the shear stress-shear rate curve (rheogram) is then defined, and this model is used to predict slurry friction head losses for pipe flow. The model may also be used to scale actual, measured, pilot loop friction losses to pipe sizes other than that used in the loop.

The rheological measurements were made with a Brookfield Model RVF viscometer over a range of slurry concentrations and at a temperature of $25^{\circ} \mathrm{C}$. The slurries were placed in a blender jar containing a heating coil which was connected to a constant temperature bath. The viscometer spindle was lowered into the slurry, which was then agitated as necessary to suspend the solids. With the blender off and the slurry in a quiescent state, the shear stress-shear rate relationships were obtained. Measurements were made with both ascending and descending spindle movements, and all measurements were repeated four to eight times. Yield stresses were obtained by recording the static torque reading when the spindle was allowed to come to rest in the slurry.

A three-parameter yield-pseudoplastic model was fitted to the data. This model does not fit all of the rheology data as well as a four- or five-parameter model would, but it is much easier to deal with mathematically. The model was adjusted to fit the rheology data over the range of shear rates to be encountered in the prototype pipeline operation. The model selected was a yield-pseudoplastic having the form

$$
\tau-\tau_{y}=k \dot{\gamma}^{n}
$$

where

$$
\begin{aligned}
& \left.\tau \text { - shcar streas (dyne/ } \mathrm{cm}^{2}\right) \\
& \tau_{y}=\text { yield shear stress (dyne } / \mathrm{cm}^{2}(\mathrm{TAUY}) * \text { ) } \\
& \mathrm{K}=\text { flow consistency index (dyne- } \sec ^{\mathrm{n}} / \mathrm{cm}^{2}(\mathrm{KYP}) * \text { ) } \\
& \dot{\gamma}=\text { shearing rate }\left(\sec ^{-1}\right) \\
& \mathrm{n}=\mathrm{flow} \text { behavior index (dimensionless (NYP) *) }
\end{aligned}
$$

(*Computer notation, used in Fig. 5.2.1.1-1) 
Utah Carbon King coal from Braztah Corp. in Helper, Utah, was crushed in a laboratory-type hammerimill (Holmes) in several passes.

$$
\begin{aligned}
& \text { Specific gravity (measured) }=1.4294 \text { a } 25^{\circ} \mathrm{C} \\
& \text { Moisture content }-1.16 \%
\end{aligned}
$$$$
\text { Screen Analysis }
$$$$
+100 \text { mesh } 0.38
$$$$
+200 \text {. } \quad 13.7
$$$$
+325 \quad 65.60
$$$$
-325 \quad \frac{20.4}{100.0 \%}
$$

\begin{tabular}{|c|c|c|c|}
\hline & $\begin{array}{c}\text { As } \\
\text { received } \\
\end{array}$ & Dry basis & $\begin{array}{l}\text { Molisture \& dsll- } \\
\text { free basis. }\end{array}$ \\
\hline Volatile matter & $37.4 \%$ & 40.28 & 47.5 \\
\hline Fixed carteon & $41 \cdot 48$ & 41.58 & 52.5 \\
\hline Ash & $14.2 \%$ & $15.3 \%$ & - \\
\hline Btu/IB & 11,355 & 12,210 & 14,420 \\
\hline sulfur & $\begin{array}{r}0.78 \\
----\end{array}$ & $\begin{array}{c}0.78 \\
---\end{array}$ & - \\
\hline
\end{tabular}

\section{Analycis of Coal}

Rheological data are listed on the computer printouts. Four concentrations were measured, two at $64 \%$ solids concentration by weight, and one each at $60 \%$ and $55 \%$. It was concluded that higher concentrations, possibly above $70 \%$ by weight, could probably be pumped, although of course plpewall friction would be high.

Nomenclature is given in Fig. 5.2.1.1. Along with the rheological data are included the predicted pressure drops to overcome pipewall friction in psi per mile. The specific power (kilowatts to transport one dry short ton of coal per hour one mile) is listed also. In both cases, pressure drop and specific power are for pipewall friction only and do not include pipeline bends, elevation differences, fitting losses, or pump motor efficiencies. 


\section{PROGAAM}

THIS PROGRAM SUMMARIZES ANO ANALYZES RHEOLOGY DATA FOR SLURRIES OR LIOUIDS MEASURED i ITII A BRTOKFIELD VISCOMETER (HOOEL LVP OR RVF) USING CYLINDRICAL SPINDLES SUOROUTIIE OPMT PERFORMS A LINEAR REGRESSION ON TAUBOB = KAOMEGAMAA SUBROUTINF, PIPE PRENICTS. PIPELIINE ENERGY REOUIREMENTS

NOTE: PROGRAM COMPITES IN SI UNITS. SJME OATA OUTPUT IS IN ENGLISH UNITS,

\section{NOMENCLA TURE}

RC = RADIUS OF CONTAINER MEASURED AT SPINDLLE LOCATIÖN" CH

RS = RADIUS OF SPINDLE, CII

BATUI: = RC/ISS HHERE I \& SPINDLE NUMAER

CW = GRAVIMETRIC.CCONCENTRATION IOECIIIAL FRACTIONI

CV = VRLUIIETRIC CONVENTRATION (OECIHAL FRACTION)

PEMP : SLURPY TEMPERATURE IN DECREES ECNTIGRADE

5 S SHECIFIC GRAVITY OF SOLIDS

SL = SPECIFIC GQAVITY OF LIOUID

TAUK (I) = SPINILLE CORFFICIENT FOR STRESS WHERE I I SPINOLE

NUMBEF:

SH = SIECIFIC GRAVITY OF SLURRY

... $\quad$ YIELO = SLURPY. FIELO. STRESS, DYHES/CM/CM

RPM = SPINIDLE SPEEO, REV/MIN

OIAL = BROUKFIELO DIAL READING

STRESS = STRESS MEASURED AT WALL OF SPINDLE, DYNES/CM/CM

EQUAIION

- BROGAY = SHEAR RATE (I/SEC) FROM GROUKEY EOUATION

F. ALVGAH = SHEAR RATE (I/SFC) FROM ALVI.S ET AL. ERUATION

OMEGA = SPINDLE ANGULAR VELOCITY, RADIANS/SEC.

$K=$ CONSISTENC* INDEX, DYNE-SEC*H/CM*2

N = FLOW REHAVIOR INOEX, OIMENSIONLESS

KYP I II!TERCEPT OF DELTAU VS ALOGAH ILOGARITHMIC PLOTI

NYP = SLOPE OF DELTAU VS, ALVGAM (LOGARITHMIC PLOT)

DELTAL = TAU - TAUY

YAU = SHEAR STRESS . DYNES/CM/CM

TAUY I YIELO
RYP $=$ COEFFICIENT OF CORRELATION FOR LEAST SOUARES FIT

OIA E PIPE INNER OIAHETER, INCHES

RELRUF = RELATIVE ROUGHNFSS (ARSOLUTE ROUGHNESSIPIPE (D)

VCL I CAITICAL VELOCITY OENOTING LAMINAR FLOW

VCT = CAITICAL VELOCITY DFNOTING TRANSITION. FLOW

VLCTY = VELOCITY OF FLOW, FPS

SHRATE $=$ SHEAR RATE. I/SF.C

THROURHPUT IS IN DRY SHORT TONS PER HOUR

RE = GENERALIZED REYNOLDS NUHBER BASED ON SLURRŸ PROPERTIES

FM = FAINIIUG FRICTION FACTOR

PDROP = PRESSIURE OROP OUE TO WALL FHICIION' ONLY, PSI/MILE KILW-HIR/TOAIAMI = SPLCIFIC POLIER 
SLURRY: SII HETHACOAL (64.3X). 3-12-77

( $\mathrm{KC}(\mathrm{CM})$ RS (CM)

24.06000 .5128

RAT(I) LNORAT(1)) $=h(x)$ CV(x) TEMP(C)

SL

TAUK(I) SM YIELOCOYNES/CH/CH)

RPM DIAL STIEESS KEMGAM BRCGAM ALVGAM OHEGA LNCOMEGAI LNISTRESS)

19. $19.5 \quad 74.632 .49 E+21 \quad 4.58 \quad 4.501 .0472 \quad 0.0461 \quad 4.3125$

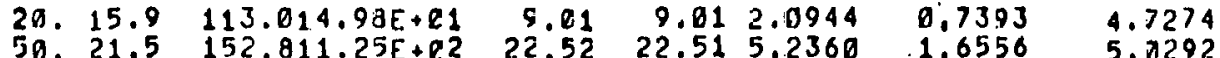

$0.3 \quad 58.0$

25.9

1.4259 .791

8.14871 .110

6.49

50. 21.5 152.011.25E.02 22.52 $22.515 .2360 \quad 1.6556$

$100.32 .2228 .062 .405+82045.03 \quad 45.0310 .4720 \quad 2.3487$

5.4331

STHESS $=75.08$ (OLEGA IN.0.465 R $=0.993368 .23$

STRESS 3 B.09(BROGAMINO D.465 R

$K=38.10 \mathrm{~N} ; 0.485 \mathrm{KYP}: 33.73 \quad$ HYP $=0.490$ RYP $=0.9931^{\circ}$

1
$N$
$N$
1

Fig. 5.2.1.1, p.2 


\section{SYSTEH PROPERTIES}

MINERAL -.. SSI METHACOAL 164,3\%: 3-12-77.

AVERAGE SOLID SPECIFIC GRAYITY IS ,

LIOUID PHASE
SLURRY SPECIFIC GRALITY (SL)

SLURRY

SLURRY CONCENTHATTIOH BY WEIGHT

SLURRY CONCENTRATIOII BY VOLIJME

$-. .9 .643$

ABSOLUTE PIPELIALL ROUGHNESS (E). FEET

CRAVITATIOIAL ACCELERATION

SLURAY TEMPERATURE (TEMP), DEGREES CELSIUS -- 25.5

PIPE TYPE

PIPE. SLOPE

- HORIZONTAL

\begin{tabular}{|c|c|}
\hline MESH & PERCENT \\
\hline $.907 / 106$ & $0.3 \dot{8}$ \\
\hline 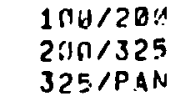 & $\begin{array}{l}13.79 \\
65.69 \\
29.49\end{array}$ \\
\hline
\end{tabular}

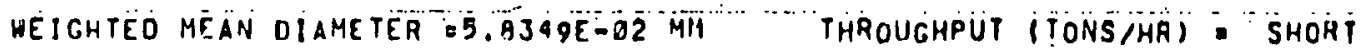
COETFICIENT OF VARIATION = 44.68801 SETTLING REGIME - LAMINAR ORAG COEFF OF WEIGHTED MEAN DIA 221,86S VISCOSITY FACTOR E. 1.0 PEYHOLDS NUHAEA OF SETTLIING $\$ .11$

FOSIN - RAMMLFR EOUATIONI $R$ = 100 EXP(-10/ Q.068649) * 2.585615)

SLOPE $=2.585015$ INIERCEPT $B=0.06864908340$ MILLIHETERS

CORRELATION COEFF. $=0.965528$ O5B $=0.06$ MILLIMETERS
$K Y P=33.73$
NYF $=9.498$
TAUY $=\ldots 6.396$.

SH. THEORY

$P H=N, A_{1}$

Fig.5.2.1.1,p. 3 
$\begin{array}{lrll}\text { DIA RELPUI } & \text { VCL } \\ \text { IN. VCT } \\ \text { EIOIA FPS FPS }\end{array}$

$6.00 \% 0.0903511 .8216 .89$ $0.0000 .0602218 .04 \quad 15.39$ $10.0190 .011018 \quad 9.3414 .31$ $12.01190 .00015 \quad 8.8013 .49$ 14.0.13 0.8.1013 $8.37 \quad 17.83$ $16.90 .10 .011011 \quad 8.8212 .28$ $18.00 .30 .02010 \quad 7.7211 .82$ $20.0690 .011009 \quad 7.46 \quad 11.43$ $22.2090 .01 .008 \quad 7.2311 .08$ $24.0040 .03007 \quad 7.0319 .77$

$6.0030 .060311 .82 \quad 16.89$ $8.0900 .01922 \quad 18.04 \quad 15.39$ $10.0140 .0 \% 018 \quad 9.3414 .31$ $12.9 n d 0.03015 \quad 8.8013 .49$ 14.0090 .02013 a.37 12.03 16.0100 8.g0911 0.0212 .28 18.ด19 0. ח9019 7.7211 .82 $20.06160 .06069 \quad 7.4611 .43$ $22.0430 .00068 \quad 7.2311 .08$ $24.0 .1190 .00097 \quad 7.2310 .77$

6.0490 .0403011 .0216 .19 8. 90 0.00ग2? $18.04 \quad 15.39$ 10. Ang $0.00018 \quad 9.34 \quad 14.31$ 12.0000 .00015 .6 .8013 .49 $14.0090 .04013 \quad 0.3712 .83$ $\stackrel{1}{\sim} 16.0010 .00011$ 0.82 12.28 \& $18.09190 .01101 \mathrm{C} \quad 7.7211 .82$

$\omega 20.099$ 0.76190.9 7.4611 .43 22 . 960 0.26.0\%8 7.2311 .08 24.06its 0.00007 ?.0319.77

6. A60 $0.05030_{11.92 ~ 16 . A 9^{\circ}}$ 8.0.119 0.0650?2 .10.04 15.39 $10.0190 .00918 \quad 3.34 \quad 14.31$ 12.91190 .001015 9.8\% 13.49 $14 . \arg 0.010013 \quad 8.37 \quad 12.83$ 16.01140 .011011 A.2? 12.28

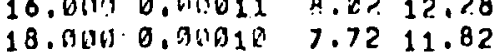

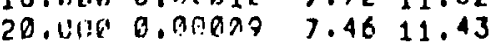
$22 . \cos 0.000007 .2311 .80$ $24.13110 .0 .0047 .93 \quad 10.77$

6. Ann 0.0̈:1038 11.0210 .99 B. $34060.0: 022,1 \%, 04,15,39$ 10. กUw $0.00018 \quad 3.3414 .31$ $12.0170 .0015 \cdot 9.8013 .49$ $14.4 .0 \quad 0.0 .013 \quad 8.37 \quad 12.83$ 16. $1190.0 .1011 \quad 9.0212 .28$ $18.9600 .7001 \% 7.7211 .82$ 20. (141) 0.0 . 22.011: 0.0.01.8 7.2311 .69
VLCTY THROUGHPUT REYNOLOS FH PS! KILH-HR IFS TUNSIIR. HUMBER HIX MI. TONAMI

\begin{tabular}{|c|c|c|c|c|c|}
\hline $\begin{array}{l}4.00 \\
4.00 \\
4.00 \\
4.00 \\
4.00 \\
4.00 \\
4.00 \\
4.00 \\
4.00 \\
4.00\end{array}$ & $\begin{array}{r}62.8 \\
111.7 \\
174.5 \\
251.3 \\
342.0 \\
446.7 \\
565.4 \\
698.0 \\
844.6 \\
1095.1\end{array}$ & $\begin{array}{l}455 . \\
523 . \\
584 . \\
639 . \\
689 . \\
735 . \\
779 . \\
820 . \\
860 . \\
897 .\end{array}$ & $\begin{array}{l}.0000 \\
.9000 \\
.0000 \\
.0000 \\
.0000 \\
.0000 \\
.0000 \\
.0000 \\
.0000 \\
.0000\end{array}$ & $\begin{array}{r}182.938 \\
119.567 \\
86.049 \\
65.778 \\
52.464 \\
43.068 \\
36.294 \\
31.054 \\
26.978 \\
23.776\end{array}$ & $\begin{array}{l}R .4465 \\
R .2918 \\
R .2100 \\
R .1606 \\
R .1281 \\
R .1451 \\
R .2885 \\
R .8758 \\
R .2659 \\
R .2580\end{array}$ \\
\hline
\end{tabular}

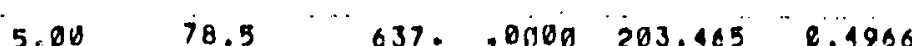
$\begin{array}{llllll}5.06 & 139.6 & 733 . & 0000 & 132.991 & 0.3246\end{array}$ $5.00 \ldots 218.1$. 81A.,DOAG . $95.694 \ldots R .2335$ 5.00 314.1 894. .9989 73.151 R.1786 $5.08 \quad 427.5 \quad 965 ., 0090 \quad 58.284 \quad 0.1423$ $5.00 \quad 558.4 \quad 1930.0999047 .8780 .1969$

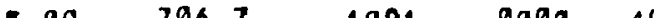

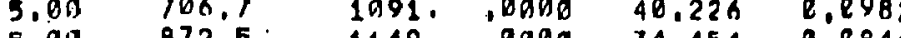
$5.00 \ldots 1055.7 \quad-1204 . . .0000 .29 .963 .2 .0731$ $5.001256 .4 \quad 1256 . .0600 \cdot 26.360 .0643$

$6.00 \quad 94.2 \quad 830 ., 0000 \quad 222.844-8.3420$

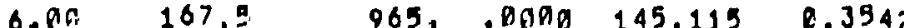
6.00 261.E 107\%, ,0400 104.345 2.2547

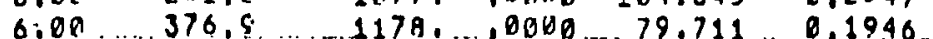

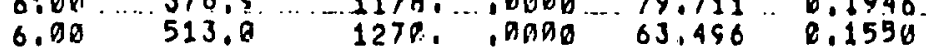
$6.00 .670 .1 \quad 1356.000052 .197 \quad 0.1273$

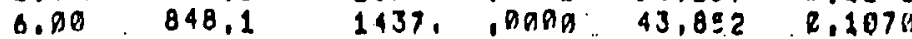
$6.00 \quad 1047.9 \quad 1513.0900 \quad 37.576 \quad 2.8917$ $6.001266 .9 \quad 1585.0000 \quad 32.647 \quad 2.8797$

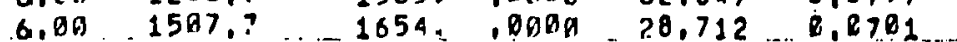

$\begin{array}{lllll}7.20 & 109.9 \quad 1058 . & .9090 & 239.121 & 0.3337\end{array}$ 7.00 .195 .1 .121月. .9006 156.218. R.3B13

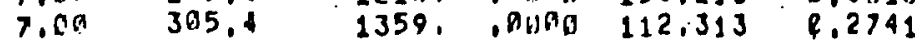
$\begin{array}{llllll}7.00 & 439.7 & 1486, & .0000 & 85.827 & 0.2395\end{array}$

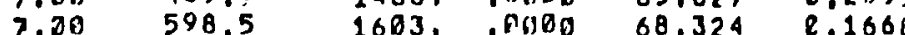

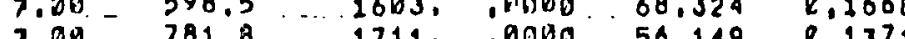
$7.09989 .4 \quad 1813$. . 9090 47.121 8.1152

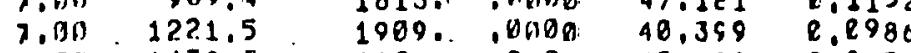
7.0 1478.0 2019. .019 35.129 R.8B57

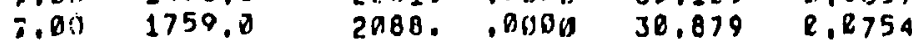

$8.00 \quad 125.8 \cdots 1294 . .0000254 .956 \quad 2.6224$ $8.00 \quad 223.4 \quad 1490.0060$. $166.5330 .400 \%$

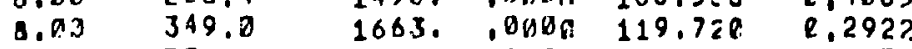

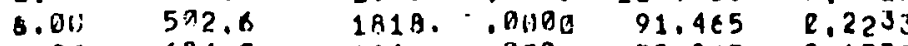
6.04 684.0 1961. .0100\% 72.847 P.1778

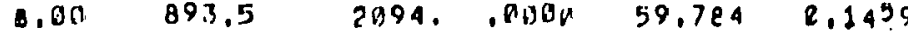
$\begin{array}{llllll}0.04 & 1130.8 & 2484.0463 & 77.956 & R .100\end{array}$

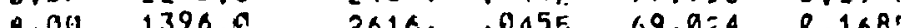
1.011 1689.? 2741 . . 440 . 61.826 R.1589
Fig.5.2.1.1,p.4 


\begin{tabular}{|c|c|c|c|c|c|c|c|c|c|}
\hline $\begin{array}{l}O I A \\
\text { IN. } \\
\text { A. ACD }\end{array}$ & $\begin{array}{r}\text { RELRUF } \\
E / 01 A \\
\text { E, DOOA7 }\end{array}$ & $\begin{array}{l}\text { VCL } \\
\text { FPS } \\
7.03\end{array}$ & $\begin{array}{l}\text { VCT } \\
\text { FPS } \\
10.77\end{array}$ & $\begin{array}{l}\text { VLCTY } \\
\text { FPS } \\
8 . P A\end{array}$ & $\begin{array}{c}\text { THROUGIIPUT } \\
\text { TOHS IIR } \\
7.010 .3\end{array}$ & $\begin{array}{c}\text { REYNOLOS } \\
\text { IIUMRER } \\
2861 .\end{array}$ & $\begin{array}{c}F H \\
M I X \\
.9442\end{array}$ & $\begin{array}{c}P S ! \\
M ! \\
55.914\end{array}$ & $\begin{array}{l}K I L K . \\
\text { TCH>R } \\
2,13\end{array}$ \\
\hline 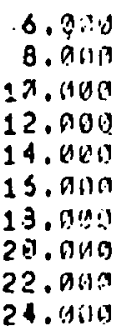 & $\begin{array}{l}0.00030 \\
0.019022 \\
0.0 \% 01.8 \\
0.010015 \\
0.0 .0013 \\
0.09011 \\
0.010010 \\
0.010000 \\
0.01008 \\
0.00007\end{array}$ & $\begin{array}{l}11.02 \\
19.04 \\
9.34 \\
8.80 \\
6.37 \\
8.02 \\
7.72 \\
7.46 \\
7.23 \\
7.03\end{array}$ & $\begin{array}{l}16.89 \\
15.39 \\
14.31 \\
13.49 \\
12.83 \\
12.78 \\
11.82 \\
11.43 \\
11.08 \\
19.77\end{array}$ & $\begin{array}{l}9.00 \\
9.00 \\
9.09 \\
9.00 \\
9.00 \\
9.00 \\
9.09 \\
9.00 \\
9.00 \\
9.00\end{array}$ & $\begin{array}{r}142.3 \\
251.3 \\
392.6 \\
565.4 \\
769.6 \\
1005.1 \\
1272.1 \\
1579.5 \\
1980.3 \\
2261.6\end{array}$ & $\begin{array}{l}1546 . \\
1780 . \\
1986 . \\
2432 \% \\
26230 \\
2801 . \\
2967 . \\
3129 . \\
3274 . \\
3417 .\end{array}$ & $\begin{array}{r}.0000 \\
.0009 \\
.0000 \\
.0468 \\
.0455 \\
.0446 \\
.0438 \\
.04331 \\
.0425 \\
.0419\end{array}$ & $\begin{array}{l}269.877 \\
176.229 \\
126.657 \\
149.127 \\
124.777 \\
106.958 \\
93.379 \\
82.712 \\
74.121 \\
67.066\end{array}$ & 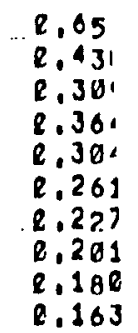 \\
\hline 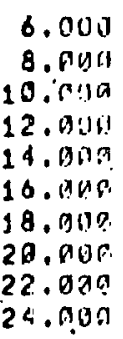 & $\begin{array}{l}0.001030 \\
0.010022 \\
0.01010 \\
0.00015 \\
0.0 \times 1013 \\
0.00011 \\
0.01010 \\
0.0 .1009 \\
0.010008 \\
0.00057\end{array}$ & $\begin{array}{r}11.02 \\
19.01 \\
9.34 \\
8.80 \\
8.37 \\
8.02 \\
7.72 \\
-7.46 \\
7.23 \\
7.03\end{array}$ & $\begin{array}{l}16.89 \\
15.39 \\
14.31 \\
13.19 \\
12.83 \\
12.28 \\
11.82 \\
11.43 \\
11.78 \\
10.77\end{array}$ & $\begin{array}{l}10.00 \\
10.00 \\
10.0 .10 \\
10.00 \\
10.00 \\
10.00 \\
10.00 \\
10.00 \\
10.00 \\
10.00\end{array}$ & $\begin{array}{r}157.1 \\
279.2 \\
436.3 \\
628.2 \\
855.1 \\
1116.8 \\
1413.5 \\
1745.0 \\
2111.5 \\
2512.8\end{array}$ & $\begin{array}{l}1813 . \\
2087 . \\
2608 . \\
2852 . \\
3076 . \\
3284 . \\
3479 . \\
3664 . \\
3839 . \\
4906 .\end{array}$ & $\begin{array}{l}.0000 \\
.0009 \\
.0456 \\
.0444 \\
.0433 \\
.9425 \\
.0417 \\
.0411 \\
.0495 \\
.0490\end{array}$ & $\begin{array}{r}203.885 \\
105.427 \\
216.271 \\
175.222 \\
146.659 \\
125.758 \\
109.865 \\
97.313 . \\
87.297 \\
78.971\end{array}$ & $\begin{array}{l}692 \\
192 \\
927 \\
127 \\
358 \\
307 \\
268 \\
237 \\
213 \\
192\end{array}$ \\
\hline 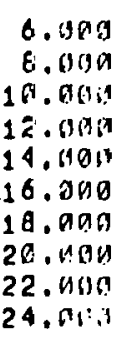 & $\begin{array}{l}0.01003: 1 \\
0.0302 ? \\
0.00010 \\
0.00015 \\
0.01013 \\
0.011011 \\
0.01010 \\
0.011000 \\
0.00008 \\
0.01007\end{array}$ & $\begin{array}{l}11.02 \\
10.64 \\
9.34 \\
0.80 \\
8.37 \\
8.02 \\
7.72 \\
7.46 \\
7.23 \\
7.03\end{array}$ & $\begin{array}{l}16.89 \\
15.39 \\
14.31 . \\
13.49 \\
12.83 \\
12.28 \\
11.82 \\
11.43 \\
11.08 \\
10.77\end{array}$ & $\begin{array}{l}11.00 \\
11.00 \\
11,00 \\
11.00 \\
11.00 \\
11.00 \\
11.00 \\
11.01 \\
11.00 \\
11.00\end{array}$ & $\begin{array}{r}172.8 \\
307.1 \\
479.9 \\
691.0 \\
940.6 \\
1228.5 \\
1554.8 \\
1919.5 \\
2322.6 \\
2764.1\end{array}$ & $\begin{array}{l}2993 . \\
2699 . \\
3011 . \\
3293 . \\
3552 . \\
3792 . \\
4917 . \\
4239 . \\
4433 . \\
4626 .\end{array}$ & $\begin{array}{l}.0000 \\
.0452 \\
.0436 \\
.0425 \\
.0415 \\
.0407 \\
.0400 \\
.0394 \\
.0388 \\
.0383\end{array}$ & $\begin{array}{r}297.270 \\
323.921 \\
250.377 \\
202.981 \\
169.981 \\
145.813 \\
127.383 \\
112.853 \\
191.220 \\
91.628\end{array}$ & $\begin{array}{l}7251 \\
790: \\
611: \\
495: \\
414 ! \\
355 ! \\
310 ! \\
2751 \\
247: \\
223:\end{array}$ \\
\hline 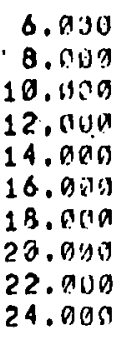 & $\begin{array}{l}0.0 .1030 \\
0.00022 \\
0.00018 \\
0.01015 \\
0.00013 \\
0.010011 \\
0.04010 \\
0.00009 \\
0.00008 \\
0.01007\end{array}$ & $\begin{array}{r}11.02 \\
19.04 \\
9.34 \\
0.83 \\
8.37 \\
8.02 \\
7.72 \\
7.46 \\
7.23 \\
7.03\end{array}$ & $\begin{array}{l}16.89 \\
15.39 \\
14.31 \\
13.49 \\
12.83 \\
12.28 \\
11.82 \\
11.93 \\
11.0 .8 \\
19.77\end{array}$ & $\begin{array}{l}12,001 \\
12.00 \\
12.00 \\
12.019 \\
12,00 \\
12.010 \\
12,00 \\
12.00 \\
12,00 \\
12.061\end{array}$ & $\begin{array}{r}188.5 \\
335.0 \\
523.5 \\
753.9 \\
1026.1 \\
1340.2 \\
1696.2 \\
2094.0 \\
2533.8 \\
3015.4\end{array}$ & $\begin{array}{l}2673 . \\
3978 . \\
3434 . \\
3755 . \\
4050 . \\
4324 . \\
4581 . \\
4824 . \\
5655 . \\
5276 .\end{array}$ & $\begin{array}{l}.0454 \\
.0434 \\
.0420 \\
.0408 \\
.0390 \\
.0391 \\
.0385 \\
.0379 \\
.0374 \\
.0369\end{array}$ & $\begin{array}{l}.266 \\
.348 \\
425 \\
.251 \\
589 \\
.971 \\
925 \\
.319 \\
.989 \\
.817 .\end{array}$ & \\
\hline 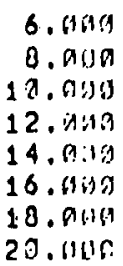 & $\begin{array}{l}0.01003 \pi \\
0.011022 \\
0.00010 \\
0.00015 \\
0.010013 \\
0.00011 \\
0.2001 . \\
0.010010\end{array}$ & $\begin{array}{r}11.02 \\
19.04 \\
9.31 \\
8.80 \\
6.37 \\
8.02 \\
7.7 ? \\
7.16\end{array}$ & $\begin{array}{l}16.89 \\
15.39 \\
11.31 \\
13.49 \\
12.83 \\
12.2 .8 \\
11.82 \\
11.43\end{array}$ & $\begin{array}{l}13.00 \\
13.00 \\
13.011 \\
13.001 \\
13.01 \\
13.00 \\
13.051 \\
93.011\end{array}$ & $\begin{array}{r}294 . ? \\
363.9 \\
567.1 \\
816.7 \\
1111.6 \\
1451.9 \\
1837.5 \\
3268,5\end{array}$ & $\begin{array}{l}3916 . \\
3473 . \\
3875 . \\
4237 . \\
4579 . \\
4889 . \\
5179 . \\
5444 .\end{array}$ & $\begin{array}{l}.0437 \\
.0419 \\
.0195 \\
.0394 \\
.0385 \\
.0370 \\
.0372 \\
.0366\end{array}$ & $\begin{array}{l}503.982 \\
419.164 \\
324.318 \\
263.085 \\
220.451 \\
109.247 \\
165.489 \\
146.657\end{array}$ & $\begin{array}{l}1.425 \% \\
1.0231 \\
0.7911 \\
0.642 \% \\
2.538 \\
2.461 \\
0.403 \\
2.358\end{array}$ \\
\hline
\end{tabular}

Fig. $5.2 .1 .1, p .5$ 


\begin{tabular}{|c|c|c|c|c|c|c|c|c|c|}
\hline $\begin{array}{l}\text { DIA } \\
\text { IN. }\end{array}$ & $\begin{array}{r}\text { HELRUF } \\
\text { E/OIA }\end{array}$ & $\begin{array}{l}\text { VCL } \\
\text { FPS }\end{array}$ & $\begin{array}{l}\text { VCT } \\
\text { FPS }\end{array}$ & $\begin{array}{l}\text { VLCTY } \\
\text { FPS }\end{array}$ & $\begin{array}{l}\text { THFOUGHPUT } \\
\text { TONS/HR }\end{array}$ & $\begin{array}{l}\text { REYNOLDS } \\
\text { PUMABER }\end{array}$ & $\begin{array}{l}F M \\
H I X\end{array}$ & $\begin{array}{r}P .8 ! \\
M !\end{array}$ & $\begin{array}{l}K I L W-H R \\
\text { TON-HI }\end{array}$ \\
\hline $\begin{array}{l}22.007 \\
24.010\end{array}$ & $\begin{array}{l}0.00006 \\
0.36097\end{array}$ & $\begin{array}{l}7.23 \\
7.03\end{array}$ & $\begin{array}{l}11.98 \\
19.77\end{array}$ & $\begin{array}{l}13.00 \\
13.00\end{array}$ & $\begin{array}{l}2744,9 \\
3266: 7\end{array}$ & $\begin{array}{l}5704 . \\
5953 .\end{array}$ & $\begin{array}{l}.0361 \\
.0357\end{array}$ & $\begin{array}{l}131.545 \\
119.121\end{array}$ & $\begin{array}{l}8.3211 \\
0.298 n\end{array}$ \\
\hline 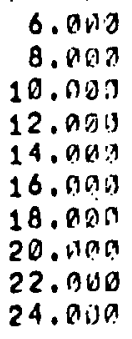 & 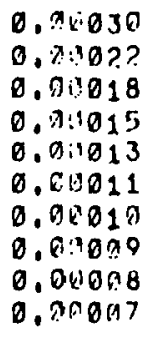 & $\begin{array}{r}11.02 \\
10.04 \\
9.34 \\
8.80 \\
8.37 \\
.002 \\
7.72 \\
7.46 \\
7.23 \\
7.03\end{array}$ & $\begin{array}{l}16.89 \\
15.39 \\
14.31 \\
13.49 \\
12.83 \\
12.28 \\
11.82 \\
11.43 \\
11.0 .8 \\
10.77\end{array}$ & $\begin{array}{l}14.00 \\
14.00 \\
14.00 \\
14.00 \\
14.00 \\
14.00 \\
14.00 \\
14.00 \\
14.00 \\
14.00\end{array}$ & $\begin{array}{r}219.9 \\
390.9 \\
619.8 \\
879.5 \\
1197.1 \\
1563.5 \\
1978.9 \\
2443.9 \\
2956.1 \\
3518.9\end{array}$ & $\begin{array}{l}3373 . \\
3884 . \\
4334 . \\
4739 . \\
5111 . \\
5457 . \\
5782 . \\
6488 . \\
6389 . \\
6658 .\end{array}$ & $\begin{array}{l}.0423 \\
.0405 \\
.9392 \\
.0381 \\
.0373 \\
.0366 \\
.0360 \\
.9359 \\
.0350 \\
.0346\end{array}$ & $\begin{array}{l}654.937 \\
478.340 \\
364.092 \\
295.421 \\
247.659 \\
212.615 \\
185.871 \\
164.821 \\
147.870 \\
133.924\end{array}$ & $\begin{array}{l}980 \\
480 \\
986 \\
211 \\
945 \\
1911 . \\
537 \\
123 \\
609 \\
909\end{array}$ \\
\hline 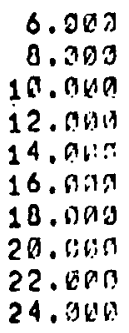 & $\begin{array}{l}0.019030 \\
0.30022 \\
0.919018 \\
0.019015 \\
0.0 .0013 \\
0.00011 \\
0.00012 \\
0.010019 \\
0.011008 \\
0.01097\end{array}$ & $\begin{array}{r}11.02 \\
10.04 \\
9.34 \\
8.86 \\
8.37 \\
8.02 \\
7.72 \\
7.46 \\
7.25 \\
7.03\end{array}$ & $\begin{array}{l}16.89 \\
15.39 \\
14.31 \\
13.49 \\
12.83 \\
12.28 \\
11.92 \\
11.43 \\
11.8 .8 \\
18.77\end{array}$ & $\begin{array}{l}15.00 \\
15.00 \\
15.00 \\
15.00 \\
15.016 \\
15.011 \\
15.00 \\
15.00 \\
15.00 \\
15.00\end{array}$ & $\begin{array}{r}235.6 \\
418.8 \\
654.4 \\
942.3 \\
: 282.6 \\
7675.2 \\
2129.2 \\
2617.5 \\
3167.2 \\
3769.3\end{array}$ & $\begin{array}{l}3744 . \\
4311 . \\
4899 . \\
5259 . \\
5672 . \\
6956 . \\
6416 . \\
6757 . \\
7089 . \\
7389 .\end{array}$ & $\begin{array}{l}.0410 \\
.0393 \\
.0380 \\
.0370 \\
.9362 \\
.9356 \\
.0350 \\
.0345 \\
.0340 \\
.0336\end{array}$ & $\begin{array}{l}729.069 \\
523.823 \\
405.549 \\
329.229 \\
276.088 \\
237.055 \\
.207 .275 \\
183.842 \\
164.949 \\
149.412\end{array}$ & $\begin{array}{l}796 \\
786 \\
910 \\
036 \\
739 \\
786 \\
059 \\
487 \\
026 \\
647\end{array}$ \\
\hline 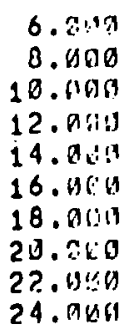 & $\begin{array}{l}0.010030 \\
0.010022 \\
0.00018 \\
0.01015 \\
0.07013 \\
0.0401 .1 \\
0.010010 \\
0.010029 \\
0.010008 \\
0.01007\end{array}$ & $\begin{array}{r}11.02 \\
10.04 \\
9.34 \\
8.82 \\
8.37 \\
8.07 \\
7.75 \\
7.46 \\
7.22 \\
7.01\end{array}$ & $\begin{array}{l}16.89 \\
15.39 \\
14.31 \\
13.49 \\
12.83 \\
12.28 \\
11.72 \\
11.13 \\
11.78 \\
19.77\end{array}$ & $\begin{array}{l}16.09 \\
16.00 \\
16.01 \\
16.00 \\
16.00 \\
16.00 \\
16.00 \\
16.00 \\
16.00 \\
16.09\end{array}$ & $\begin{array}{r}251.3 \\
446.7 \\
698.9 \\
1005.1 \\
1368.1 \\
1786.9 \\
2261.6 \\
2792.0 \\
3378.4 \\
7029.5\end{array}$ & $\begin{array}{l}4127 . \\
4752 . \\
5302 . \\
5797 . \\
6293 . \\
6676 . \\
7073 . \\
7448 . \\
7894 . \\
8145 .\end{array}$ & $\begin{array}{l}.0390 \\
.0382 \\
.0370 \\
.0360 \\
.0353 \\
.0346 \\
.0341 \\
.0336 \\
.0331 \\
.0327\end{array}$ & $\begin{array}{l}.324 \\
.572 \\
.928 \\
.482 \\
.697 \\
.347 \\
.623 \\
.675 \\
.769 \\
.574\end{array}$ & $\begin{array}{l}1.9681 \\
1.4147 . \\
1.8957 \\
2.8897 \\
R .7462 \\
R .6408 \\
2.9684 \\
2.4971 \\
2.4461 \\
e .4941\end{array}$ \\
\hline
\end{tabular}

Fig.5.2.1.1,p.6 
FIUR TATA POIITS

SLURRY: SSI IIETHACOAL $163.7 \%)$ 3-12-77

$\begin{array}{lll}1 & R C(C 11) & R S(C M) \\ 2 & 4.9100 & 0.5128\end{array}$

RAT(I) LN(RAT(I)) CW(X) CV(X) TEMP(C) S

SL TAUK(1)

YIELOCOYNES/CM/CH)

RPM DIAL 'JTFESS' KEMGAM BROGAM ALVGAH ÖMEGA

10. $7.8 \quad 49.894 .53 \mathrm{E}+99 \quad 3.44 \quad 3.431 .0472$

LNCOMECAI LNISTRESSI

$0.0461 \quad 3.9099$

$\begin{array}{lllllll}3.7 & 49.2 & 25.1 & 1.429 & 0.791 & 0.1487 & 1.109\end{array}$

TAU-TAUY

4.143 月

STRESS : $44.67($ OMEGA ) 0.610

$\begin{array}{lll}R=0.9908 & T A-T A U Y \\ R & =0.55 \\ R & =0.9998 & 60.70\end{array}$

AJ.A49.1NE + DA

$\begin{array}{rrrr}50.15 .8 & 119.402 .26 E+91 & 17.19 & 17.175 .2360 \\ 120.27 .7 & 196.944 .53 E+01 & 34.37 & 34.3316 .720\end{array}$

1.6556

4.7825

STHESS $=10.28($ KEIIGAM)* 0.610

STHESS $=21.63($ BROGAM) $\because 0.610$ R 0.9908117 .06
STHESS $=21.65($ ALVGAM) $\cdots 0.619$ R 0.9908194 .60

$K=21.84 \quad N=0.610 \quad K Y P=\ddot{P} 0.22 \quad N Y P=0.026 \quad \ddot{R Y P}=\ddot{9}=9912$ 


\section{SYSTEM PZOPERTIES}

MINERAL -. SSI HE HACOAL $(63,7 \%)$

AVEFIGE SOLIO SPECIFIC CRAVITV (S) $\cdots 1.429$

SPECIFIC CAAAVITO (SL) -.. 0.731

SLURRY

SPECIFIC CRAVIT (SII) - - 1.135

SLIIRRY CONCEMTRATION EY HEIGHT

$-\infty .637$

SLURRY CONCENTHATION EY VOLUME

ABSOLUTE PIPEWALL ROUCHLESS IES, FEE- O.DODISBAO

GRAVITATIOIAL ACCELERATION
SLURRY TEMPELATURE (TEMFI, DEGREES CLLSIUS $-\cdots 32.15$
-25.1

PIPE TYPE

PIPE. SLOFE

HOR!ZONTAL

\begin{tabular}{|c|c|}
\hline MESH & PER:FN \\
\hline 4.09187096 & 0.30 \\
\hline $\begin{array}{l}1: 3+204 \\
234 / 325 \\
325 / P A N\end{array}$ & $\begin{array}{l}13.70 \\
65.60 \\
20.40\end{array}$ \\
\hline OTAL $=$ & \\
\hline
\end{tabular}

WEIGHTED MF.AN DIAMETER =3.8349E-A2 MY COEFFICIENT OF VARIATION = $44,6 B 8 B 1$ DRAG COEFF OF WEIGMTED MEAN DIA 221.865 SEITLING REOIME L LAMINAR REYHOLOS NUMAEA OF SEPTLING -

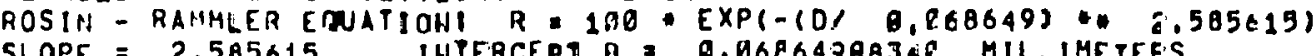

SLOPE $=2,585615$ IHPERCEPT D O O,O6E6478B34F. MIL-IMETEFS

CORRELATIOH COEFF. 0.065520 D58 * R.DB MILLIMETERS
KYP $=2 \because .22$
NYPP $=0.626$
$T$ ANY =
2,345

SH THEORY

$P_{H}=N_{1} A_{1}$

Fig.5.2.1.1.,p.8 


\begin{tabular}{|c|c|c|c|c|c|c|c|c|c|}
\hline $\begin{array}{l}\text { DIA } \\
\text { IN. }\end{array}$ & $\begin{array}{r}\text { RELRUT } \\
\text { E/OIA }\end{array}$ & $\begin{array}{l}\text { VCL } \\
\text { FPS }\end{array}$ & $\begin{array}{l}\text { V.CT } \\
\text { FPS }\end{array}$ & $\begin{array}{l}\text { VLCTY } \\
\text { IPS }\end{array}$ & $\begin{array}{l}\text { THROUGHPUT } \\
\text { TONS/HR }\end{array}$ & $\begin{array}{l}\text { REYNOLOS } \\
\text { NIJMBER }\end{array}$ & $\begin{array}{l}F H \\
H I X\end{array}$ & $\begin{array}{r}P S I \\
\ldots . M I\end{array}$ & $\begin{array}{l}\text { KILKIHA } \\
\text { POHI-HI. }\end{array}$ \\
\hline $\begin{array}{l}.009 \\
.009 \\
.000 \\
.000 \\
.000 \\
.009 \\
.009 \\
.009 \\
.009 \\
.000\end{array}$ & $\begin{array}{l}0.010030 \\
0.010022 \\
0.70018 \\
0.31015 \\
0.01013 \\
0.011011 \\
0.03015 \\
0.011009 \\
0.00008 \\
0.0 .1007\end{array}$ & $\begin{array}{r}12.47 \\
10.94 \\
9.88 \\
9.09 \\
8.47 \\
7.97 \\
7.56 \\
7.29 \\
6.90 \\
6.03\end{array}$ & $\begin{array}{l}19.93 \\
17.48 \\
15.79 \\
11.53 \\
13.55 \\
12.75 \\
12.98 \\
11.31 \\
11.92 \\
10.59\end{array}$ & $\begin{array}{l}4.00 \\
4.015 \\
4.01 \\
4.00 \\
4.00 \\
4.015 \\
4.00 \\
4.00 \\
4.00 \\
4.00\end{array}$ & $\begin{array}{r}61.9 \\
119.1 \\
172.1 \\
217.8 \\
337.2 \\
440.5 \\
557.5 \\
688.2 \\
832.8 \\
991.9\end{array}$ & $\begin{array}{l}440 . \\
527 . \\
607 . \\
689 . \\
749 . \\
814 . \\
876 . \\
936 . \\
994 . \\
1949 .\end{array}$ & $\begin{array}{l}.0000 \\
.0000 \\
.01000 \\
.0000 \\
.0000 \\
.0000 \\
.0000 \\
.0000 \\
.0000 \\
.0000\end{array}$ & $\begin{array}{r}184,843 \\
116,035 \\
80,827 \\
60.225 \\
46,915 \\
37,775 \\
31,267 \\
26,388 \\
22,622 \\
19.662\end{array}$ & 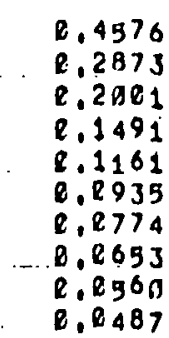 \\
\hline 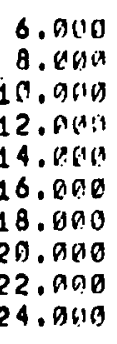 & $\begin{array}{l}0.00030 \\
0.01022 \\
0.04018 \\
0.013015 \\
0.00013 \\
0.010011 \\
0.00010 \\
0.000109 \\
0.00008 \\
0.040907\end{array}$ & $\begin{array}{r}12.47 \\
10.94 \\
9.88 \\
9.09 \\
8.47 \\
7.97 \\
7.56 \\
7.20 \\
6.90 \\
6.63\end{array}$ & $\begin{array}{l}19.93 \\
17.48 \\
15.79 \\
14.53 \\
13.55 \\
12.75 \\
12.08 \\
11.51 \\
11.92 \\
10.59\end{array}$ & $\begin{array}{l}5.00 \\
5.00 \\
5.00 \\
5.00 \\
5.00 \\
5.00 \\
5.00 \\
5.00 \\
5.00 \\
5.00\end{array}$ & $\begin{array}{r}77.4 \\
137.6 \\
215.1 \\
389.7 \\
421.5 \\
550.6 \\
696.8 \\
860.3 \\
1040.9 \\
1238.8\end{array}$ & $\begin{array}{l}590^{\circ} \\
717 . \\
8240^{\circ} \\
9240^{\circ} \\
1917 . \\
1180^{\circ} \\
1191 . \\
1272 . \\
1350^{\circ} \\
1420^{\circ}\end{array}$ & $\begin{array}{l}.0000 \\
.0000 \\
.0000 \\
.0000 \\
.0000 \\
.0000 \\
.0000 \\
.0000 \\
.0000 \\
.0000\end{array}$ & $\begin{array}{r}212.262 \\
133.129 \\
92.828 \\
69.096 \\
53.899 \\
43.485 \\
35.829 \\
30.228 \\
25.929 \\
22.561\end{array}$ & 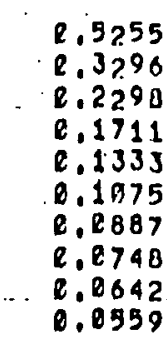 \\
\hline $\begin{array}{l}6.0190 \\
8.0150 \\
0.0100 \\
2.000 \\
4.0100 \\
6.0109 \\
8.01109 \\
0.01100 \\
2.000 \\
4.01000\end{array}$ & $\begin{array}{l}0.00030 \\
0.00022 \\
0.00018 \\
0.00015 \\
0.010013 \\
0.011011 \\
0.0 .0010 \\
0.01 .0009 \\
0.00008 \\
0.00007\end{array}$ & $\begin{array}{r}12.47 \\
10.94 \\
9.88 \\
9.09 \\
8.47 \\
7.97 \\
7.56 \\
7.20 \\
6.97 \\
6.63\end{array}$ & $\begin{array}{l}19.93 \\
17.48 \\
15.79 \\
14.53 \\
13.55 \\
12.75 \\
12.98 \\
11.51 \\
11.82 \\
10.59\end{array}$ & $\begin{array}{l}6.00 \\
6.00 \\
6.00 \\
0.00 \\
6.00 \\
6.00 \\
6.00 \\
6.00 \\
6.00 \\
6.00\end{array}$ & $\begin{array}{r}92.9 \\
165.2 \\
258.1 \\
371.6 \\
505.8 \\
669.7 \\
636.2 \\
1032.3 \\
1249.1 \\
1486.6\end{array}$ & $\begin{array}{r}769: \\
921 . \\
1059 . \\
1187 . \\
1397 . \\
1421 . \\
1538: \\
1634 . \\
1735 . \\
1832 .\end{array}$ & $\begin{array}{l}.0000 \\
.01000 \\
.0000 \\
.0000 \\
.0000 \\
.0000 \\
.0000 \\
.0000 \\
.0000 \\
. O O D O\end{array}$ & $\begin{array}{r}237,754 \\
149.122 \\
103,827 \\
77,357 \\
68,269 \\
48,502 \\
40,190 \\
33,814 \\
29.067 \\
25,183\end{array}$ & $\begin{array}{l}R \\
e \\
e \\
e \\
e \\
e \\
e \\
R \\
e \\
D\end{array}$ \\
\hline $\begin{array}{l}.0003 \\
.008 \\
.009 \\
.009 \\
.000 \\
.069 \\
.000 \\
.090 \\
.000 \\
.0190\end{array}$ & 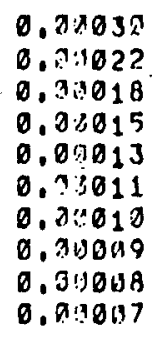 & $\begin{array}{r}12.47 \\
10.94 \\
9.68 \\
9.99 \\
8.47 \\
7.97 \\
7.96 \\
7.20 \\
6.99 \\
6.63\end{array}$ & $\begin{array}{l}19.93 \\
17.48 \\
15.79 \\
14.33 \\
13.55 \\
12.75 \\
12.98 \\
11.31 \\
11.92 \\
10.59\end{array}$ & $\begin{array}{r}7.00 \\
7.00 \\
7.00 \\
7.017 \\
7.019 \\
7.00 \\
7.00 \\
7.00 \\
7.00 \\
7.00\end{array}$ & $\begin{array}{r}108.4 \\
192.7 \\
301.1 \\
433.6 \\
590.2 \\
77.9 .8 \\
975.6 \\
1204.4 \\
1457.3 \\
1734.3\end{array}$ & $\begin{array}{l}958 . \\
1138 . \\
1308 . \\
1467 . \\
1615 . \\
1750 . \\
1890 . \\
2019 . \\
2339 . \\
2479 .\end{array}$ & $\begin{array}{l}.0000 \\
.0000 \\
.0000 \\
.0000 \\
.0000 \\
.0000 \\
.0000 \\
.0000 \\
.0471 \\
.0463\end{array}$ & $\begin{array}{r}261.617 \\
164.085 \\
114.297 \\
85.060 \\
66.386 \\
53.386 \\
44.111 \\
37.231 \\
19.541 \\
14.643\end{array}$ & $\begin{array}{l}0.218 \\
R .164 \\
e .132 \\
e .190 \\
R .892 \\
0.122 \\
0.110\end{array}$ \\
\hline 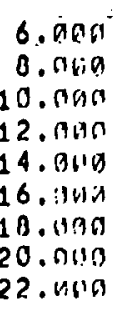 & 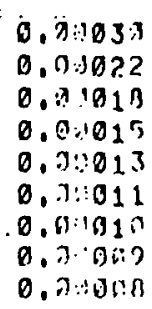 & $\begin{array}{r}12.47 \\
19.94 \\
9.88 \\
9.09 \\
8.47 \\
7.97 \\
7.56 \\
7.20 \\
6.90\end{array}$ & $\begin{array}{l}19.93 \\
17.48 \\
15.79 \\
14.53 \\
13.55 \\
12.75 \\
17.88 \\
11.81 \\
11.112\end{array}$ & $\begin{array}{l}8.00 \\
8.010 \\
8.011 \\
8.01: 5 \\
8.201 \\
8.0: 1 \\
8.0: 1 \\
0.011 \\
8.01:\end{array}$ & $\begin{array}{r}123.9 \\
220.2 \\
344.1 \\
475.5 \\
674.5 \\
880.9 \\
1114.9 \\
1376.5 \\
1655.5\end{array}$ & $\begin{array}{l}1141 . \\
1367 . \\
1572 . \\
1762 . \\
1940 . \\
2392 . \\
2478 . \\
2647 . \\
2819 .\end{array}$ & $\begin{array}{l}.0000 \\
.0000 \\
.0003 \\
.0600 \\
.01000 \\
.0474 \\
.0463 \\
.0453 \\
.0445\end{array}$ & $\begin{array}{r}284.298 \\
178,316 \\
124.160 \\
92.421 \\
71.996 \\
09.471 \\
77.782 \\
68.454 \\
61.117\end{array}$ & $\begin{array}{l}Q .228 \text { 月 } \\
e .1702 \\
e .2215 \\
R .1921 \\
R .1096 \\
e .1513\end{array}$ \\
\hline
\end{tabular}

Fig. 5.2.1.1,p.9 


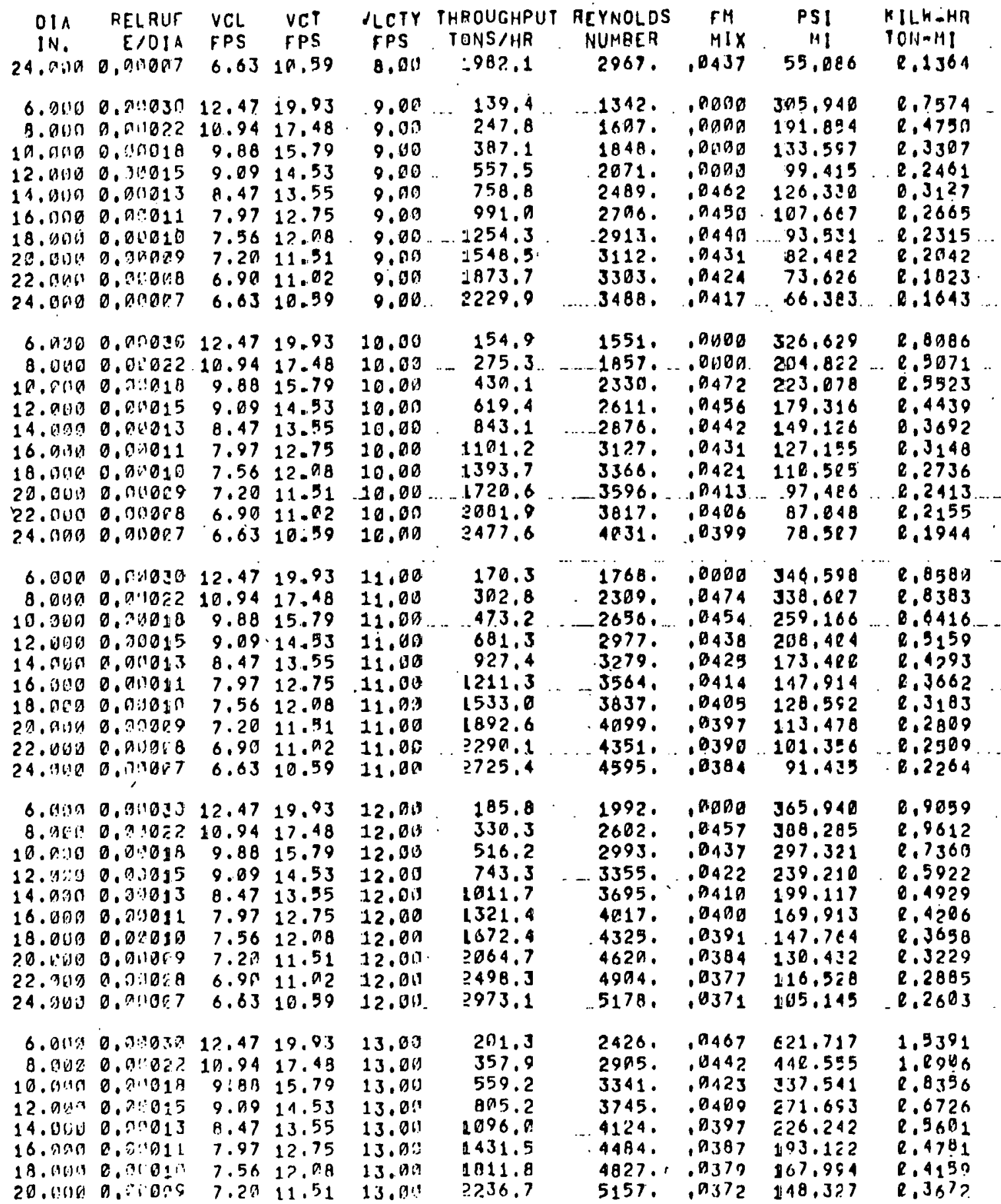

Fig.5.2.1.1,plo 


\begin{tabular}{|c|c|c|c|c|c|c|c|c|c|}
\hline $\begin{array}{l}\text { DIA } \\
\text { IV. }\end{array}$ & $\begin{array}{r}\text { RELRUF } \\
\text { E/DIA }\end{array}$ & $\begin{array}{l}\text { YCL } \\
\text { FPS }\end{array}$ & $\begin{array}{l}\text { VCY } \\
\text { FPS }\end{array}$ & $\begin{array}{l}\text { VLCTY } \\
\text { FPS }\end{array}$ & $\begin{array}{l}\text { THROUGHPUT } \\
\text { TONS } / H P \text {. }\end{array}$ & $\begin{array}{l}\text { REYNOLDS } \\
\text { NUMBER }\end{array}$ & $\begin{array}{l}F M \\
M I X\end{array}$ & PS! & $\begin{array}{l}\text { KILKEHR } \\
\text { YCH-HII }\end{array}$ \\
\hline 2. nua & $\begin{array}{l}0.00068 \\
0.01007\end{array}$ & $\begin{array}{l}6.90 \\
6.03\end{array}$ & $\begin{array}{l}11.22 \\
18.59\end{array}$ & $\begin{array}{l}13,04 \\
13,011\end{array}$ & $\begin{array}{l}2736.4 \\
3229.8\end{array}$ & & $\begin{array}{l}.0365 \\
.0360\end{array}$ & $\begin{array}{l}32.545 \\
19.621\end{array}$ & $\begin{array}{l}281 \\
961\end{array}$ \\
\hline 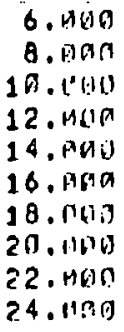 & 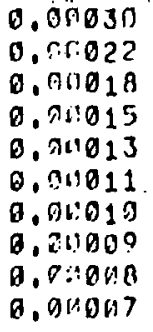 & $\begin{array}{r}12.47 \\
10.94 \\
9.88 \\
9.09 \\
8.47 \\
7.97 \\
7.96 \\
7.20 \\
6.98 \\
6.63\end{array}$ & $\begin{array}{l}19.93 \\
17.48 \\
15.79 \\
14.93 \\
13.55 \\
12.75 \\
12.98 \\
11.51 \\
11.92 \\
19.59\end{array}$ & $\begin{array}{l}14.00 \\
14.00 \\
14.00 \\
14.00 \\
14.00 \\
14.00 \\
14.00 \\
14.00 \\
14.00 \\
14.00\end{array}$ & $\begin{array}{r}216.8 \\
385.4 \\
692.2 \\
867.2 \\
1180.3 \\
1541.6 \\
1951.1 \\
2406.8 \\
2914.6 \\
3468.7\end{array}$ & $\begin{array}{l}6 . \\
6 . \\
8 . \\
6 . \\
6 . \\
4 . \\
9 . \\
9 . \\
9 . \\
9 .\end{array}$ & $\begin{array}{l}.0453 \\
.0428 \\
.9410 \\
.0397 \\
.0389 \\
.9376 \\
.0368 \\
.0361 \\
.0355 \\
.0359\end{array}$ & $\begin{array}{l}696,817 \\
495,430 \\
379,781 \\
395,819 \\
254.746 \\
217.516 \\
109,243 \\
167.142 \\
149.388 \\
134.847\end{array}$ & $\begin{array}{l}86 \\
65 \\
82 \\
71 \\
86 \\
85 \\
65 \\
38 \\
98 . \\
38\end{array}$ \\
\hline 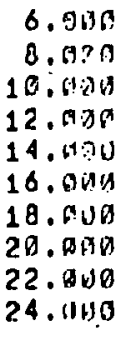 & $\begin{array}{l}0.010303 \\
0.01022 \\
0.0 .1010 \\
0.02015 \\
0.01013 \\
0.01011 \\
2.01010 \\
2.00099 \\
2.01000 \\
0.0 \% 007\end{array}$ & $\begin{array}{r}12.47 \\
19.94 \\
9.89 \\
9.09 \\
0.47 \\
7.97 \\
7.96 \\
7.20 \\
0.99 \\
6.63\end{array}$ & $\begin{array}{l}19.93 \\
17.48 \\
15.79 \\
14.53 \\
13.55 \\
12.75 \\
12.98 \\
11.51 \\
11.92 \\
19.59\end{array}$ & $\begin{array}{l}15.00 \\
15.00 \\
15.00 \\
15.00 \\
15.00 \\
15.00 \\
15.00 \\
15.00 \\
15.00 \\
15.00\end{array}$ & $\begin{array}{r}232.3 \\
412.9 \\
345.2 \\
729.1 \\
1264.6 \\
1351.7 \\
2090.5 \\
2580.8 \\
3122.8 \\
3716.4\end{array}$ & $\begin{array}{l}29 \\
35 \\
40 \\
45 \\
50 \\
58 \\
58 \\
62 \\
66 \\
98\end{array}$ & $\begin{array}{l}.0440 \\
.0416 \\
.0399 \\
.0386 \\
.0375 \\
.0366 \\
.0358 \\
.0352 \\
.0346 \\
.0341\end{array}$ & $\begin{array}{l}77 \\
55 \\
42 \\
.34 \\
28 \\
24 \\
21 \\
18 \\
16 \\
15\end{array}$ & $\begin{array}{l}93 \\
87 \\
97 \\
26 \\
46 \\
18 \\
37 \\
26 \\
35 \\
33\end{array}$ \\
\hline 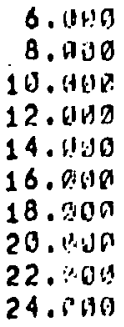 & $\begin{array}{l}0.019032 \\
0.019022 \\
0.001012 \\
0.011015 \\
0.00013 \\
0.30011 \\
0.09010 \\
0.010010 \\
0.20300 \\
0.05007\end{array}$ & $\begin{array}{r}12.47 \\
10.94 \\
9.88 \\
9.09 \\
8.17 \\
7.97 \\
7.56 \\
7.20 \\
6.90 \\
6.03\end{array}$ & $\begin{array}{l}19.93 \\
17.48 \\
15.79 \\
14.93 \\
13.55 \\
12.75 \\
12.98 \\
11.51 \\
11.02 \\
19.59\end{array}$ & $\begin{array}{l}16,00 \\
16.00 \\
16.00 \\
16.00 \\
16.00 \\
16.00 \\
16.00 \\
16.00 \\
16.00 \\
16.00\end{array}$ & $\begin{array}{r}247.8 \\
-\quad 48.5 \\
688.7 \\
991.0 \\
1348.9 \\
1761.9 \\
2229.9 \\
2752.9 \\
3331.0 \\
3964.2\end{array}$ & $\begin{array}{l}3227 . \\
3864 . \\
4443 . \\
4981 . \\
5485 . \\
5964 . \\
6421 . \\
6858 . \\
7280 . \\
7688 .\end{array}$ & $\begin{array}{l}.0429 \\
.0406 \\
.0309 \\
.0376 \\
.8366 \\
.0357 \\
.0350 \\
.0343 \\
.0338 \\
.0333\end{array}$ & $\begin{array}{l}863.345 \\
612.798 \\
478.170 \\
378.874 \\
315.787 \\
269.773 \\
234.814 \\
297.467 . \\
185.494 \\
167.498\end{array}$ & $\begin{array}{l}1373 \\
9170 \\
1639 \\
9379 \\
7818 . \\
6070 \\
90114 \\
9136 . \\
4592 \\
4146\end{array}$ \\
\hline
\end{tabular}


FOUR DATA POIIITS

SLURRY: SSI HETHACDAL $(59.2 \times)$

$3-12-77$

$1 \mathrm{AC}(\mathrm{CM}) \mathrm{RS}(\mathrm{CM})$

14.00000 .9421

RAT(I) LN(RAT(I)) CN(X) CV(X) TEMP(C)

SL

TAUKCi) SM YIELOCCYNESICHOCNAI

RPM DIAL STRESS KEMGAM "BROGAM ALVGÄM OMEGA LNIOMEGAI LN(STPESSI
19. $32.6 \quad 56.049 .6$ BE+00.
$5.36 \quad 5.36 \quad 1.0472$
$0.0461 \quad 4.0269$
20. 51.1. $87.961: 94 E+8: 1$
50. 68.7
$87.961 .94 E+8.1$
$18.204 .34 E+81$
$10.72 \quad 19.722 .0944$
$0,7.393$
4. 42069
STRES
STRESS
$26.705 .2360 \quad 1.6556 \quad 4.772$
4.772
STRESS = 31.51(BROGAH) *0.391

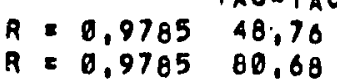

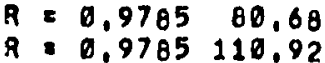
$53,31.53,5810.4720$
2,348 ?
STRESS $=31,51$ (ALVGAH) * 0.391
ค. $=0.9785134 .04$ 25.9

1.4290 .7910 .58141 .076

TAÜ-YิAU
48,70

$K=31.51 \mathrm{~N}=0.391 \mathrm{KYF} \cdot 26.15^{\circ} \mathrm{NYP}=0.427$ RYP 0.9761

LAST THREE DATA POINTS

SLURRY: SSI HETHACJA

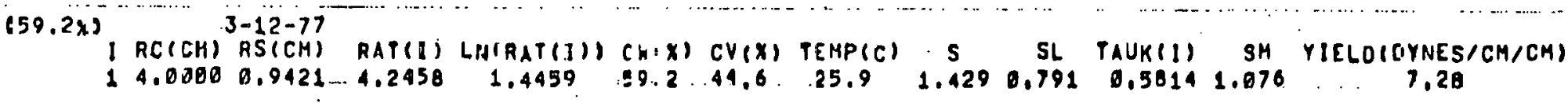

I RC(CH) RS(CM) RAP(I) LPIAAT(II) CH:X) CV(X) TEMP(C) S S SL TAUK(I) SH YIELO(CYYES/CM/CH)

$14.00000 .9421 \ldots 4.2458 \quad 1.4459 \quad 9.2 \ldots 44.6 .25 .9 \quad 1.4290 .7910 .58141 .076$ 7.28

RPM DIAL STRESS KEMCAM BROCAM ALVGAM OMEGA LN(OHEGA) LN(STRESSI

10. $32.6 \quad 56.049 .68 E+8 P \quad 5.36 .5 \% 36.1 .6472=0461 \quad 4.0260$

20. $51.1 \quad 97.961 .94 E+81 \quad 10.72 \quad 19.722 .0944-07393 \quad 4.9769$

59. $68.7 \quad 118.284 . B 4 E+99 \quad 26.81 \quad 26.705 .2360 \quad 1.6555$

100.82 .2141 .318 .605401

$53,61.53,5810,4720 \ldots 2,348$ ?

1.9510

STRESS 25.01(KEMGAM) 0.391

STRESS 31.51 (BROGAM) 0.301

ค $=$

$K=31.51 \mathrm{~N}=0.391 \mathrm{KYF}=38.36 \mathrm{NYP}=0.317$ RYP 0.9978

STRESS - 31.51(ALYGAM) 0.391 A 0.9785118 .92 


\section{SYSTEM PROPERTIES}

MINERAL -.. SSI METHACOAL $(59,2 \times)$ 3-12-7)

AVERAGE SOLIO SPECIFIC GRAVITY IS,

LIOUID PHASE S SPECIFIC GRAVITY. (SL) $\cdots 0.791$

SLURRY SPECIFIC GRAVITY (SM)

SLURRY CONCENTILATION BY WEIGHT

$=0.592$

SLURRY CONCENTRATIOMI BY VOLUME

$\cdots 0.446$

ABSOLUTE PIPEHALL ROUGHNESS (E), TEET =-\% 0.00015000

GRAVITATIOHAL ACCELFRATION

SLURRY TEMPERATURE (TEMP). DEGREES CELSIUS - 25.9

PIPE TYPE

PIPE SLOPE

HORIZONTAL

MESH PERCENT

$\begin{array}{lr}0.007 / 129 & 0.30 \\ 100 / 224 & 13.79 \\ 2061 / 325 & 65.60 \\ 325 / P A N & 28.49 \\ \text { TOTAL } 200.9\end{array}$

TOTAL $\equiv 200$.

WE ITIHTEO MEAN DIAHETER ES. BJ $49 E-02$ MM COEFFICIENT OF VARIATION $=44.680 A 1$

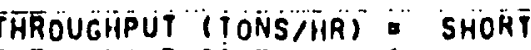

930 SEYTLING REGIME = LAMINAR

FEYHOLDS NIJMAER OF SETTLING E

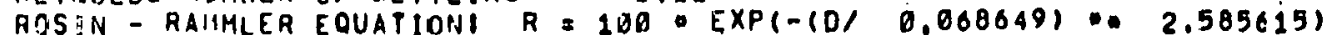

SLOPE $=2.585615$ INTERCEPI B. 0.0686490834 M MILLIMETERS

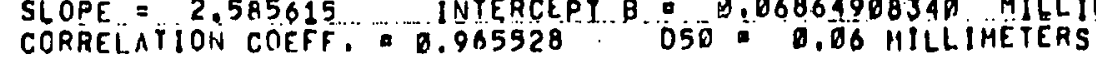

KYP $=38.36$

WYP $=0.31 ?$

TAUY $=\ldots .7 .275$

SM THEOFY

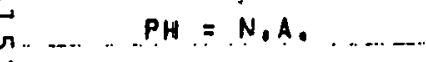

Fig.5.2.1.1,p.13 


\begin{tabular}{|c|c|c|c|c|c|c|c|c|c|}
\hline $\begin{array}{l}\text { DIA } \\
\text { IN. }\end{array}$ & $\begin{array}{l}\text { FELARIIF } \\
\text { EIDIA }\end{array}$ & $\begin{array}{l}V C L \\
\text { FPS }\end{array}$ & $\begin{array}{l}\text { VET } \\
\text { FPS }\end{array}$ & $\begin{array}{l}\text { LCTY } \\
\text { FPS }\end{array}$ & $\begin{array}{l}\text { THROUSIIPUT } \\
\text { TONS/HR }\end{array}$ & $\begin{array}{l}\text { REYNOL DS } \\
\text { NUMBER }\end{array}$ & $\begin{array}{l}F M \\
M I X\end{array}$ & $\begin{array}{l}\text { PSI } \\
\mathrm{MI}\end{array}$ & $\begin{array}{l}K I I, N-H A \\
T C N-H I I\end{array}$ \\
\hline 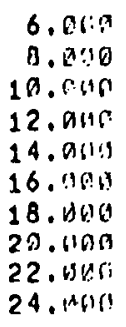 & $\begin{array}{l}0.00030 \\
0.010022 \\
0.0 .0018 \\
0.010015 \\
0.00013 \\
0.7 ! 011 \\
0.0: 1010 \\
0.960 .090 \\
0.01 \% 0118 \\
0.011897\end{array}$ & $\begin{array}{l}7.22 \\
6.83 \\
6.55 \\
6.33 \\
6.15 \\
6.00 \\
5.87 \\
5.75 \\
5.65 \\
5.56\end{array}$ & $\begin{array}{r}19.58 \\
10.02 \\
9.01 \\
9.2 .9 \\
9.92 \\
8.80 \\
8.09 \\
8.44 \\
8.28 \\
8.15\end{array}$ & $\begin{array}{l}4.00 \\
4.019 \\
4.00 \\
4.00 \\
4.00 \\
4.00 \\
4.00 \\
4.00 \\
4.00 \\
4.00\end{array}$ & $\begin{array}{r}56.1 \\
99.7 \\
155.7 \\
224.2 \\
365.2 \\
398.6 \\
594.5 \\
622.8 \\
753.6 \\
896.9\end{array}$ & $\begin{array}{l}778 . \\
852 . \\
915 . \\
969 . \\
1618 . \\
1062 . \\
1102 . \\
1140 . \\
1175 . \\
1208 .\end{array}$ & 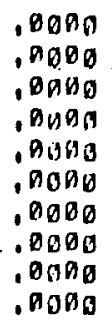 & $\begin{array}{r}106.182 \\
72.961 \\
54,552 \\
43.180 \\
35.284 \\
29,687 \\
25,452 \\
22.217 \\
19.602 \\
17.547\end{array}$ & $\begin{array}{l}R, 2902 \\
R, \$ 996 \\
R, 1493 \\
R, 1179 \\
R, R 965 \\
R, R 812 \\
R, 8697 \\
R, R 688 \\
R, R 538 \\
R, R 489\end{array}$ \\
\hline 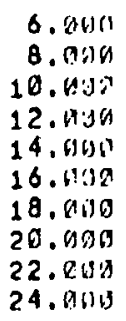 & 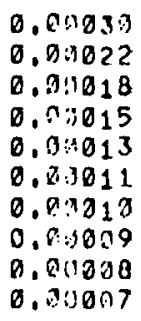 & $\begin{array}{l}7.22 \\
6.83 \\
6.55 \\
6.33 \\
6.15 \\
6.00 \\
5.87 \\
5.75 \\
5.65 \\
5.56\end{array}$ & $\begin{array}{r}119.58 \\
10.02 \\
9.81 \\
9.29 \\
9.92 \\
8.80 \\
8.00 \\
8.43 \\
8.28 \\
8.15\end{array}$ & $\begin{array}{l}5.00 \\
5.00 \\
5.00 \\
5.00 \\
5.00 \\
5.00 \\
5.00 \\
5.00 \\
5.00 \\
5.00\end{array}$ & $\begin{array}{r}79.1 \\
124.6 \\
194.6 \\
280.3 \\
361.9 \\
498.3 \\
639.6 \\
778.6 \\
942.1 \\
1121.1\end{array}$ & $\begin{array}{l}3 . \\
1 . \\
2 . \\
1 . \\
2 . \\
6 . \\
5 . \\
9 . \\
9 . \\
8 .\end{array}$ & $\begin{array}{l}.0000 \\
.0000 \\
.0000 \\
.8000 \\
.0000 \\
.0000 \\
.0000 \\
.0000 \\
.0000 \\
.0000\end{array}$ & $\begin{array}{r}113.498 \\
78.028 \\
58.385 . \\
46.077 \\
37.713 \\
31.721 \\
27.229 \\
23.790 \\
20.979 \\
18.752\end{array}$ & $\begin{array}{l}2 \\
60 \\
45 \\
59 \\
13\end{array}$ \\
\hline 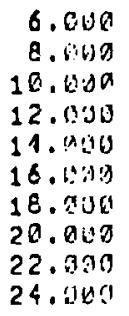 & 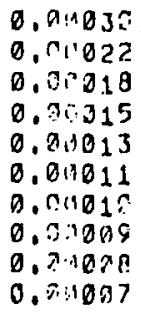 & $\begin{array}{l}7.22 \\
6.83 \\
6.55 \\
6.33 \\
6.15 \\
6.09 \\
5.87 \\
5.75 \\
5.05 \\
5.56\end{array}$ & $\begin{array}{r}10.58 \\
19.82 \\
9.61 \\
9.29 \\
9.22 \\
8.80 \\
8.60 \\
8.43 \\
8.28 \\
.8 .15 .\end{array}$ & 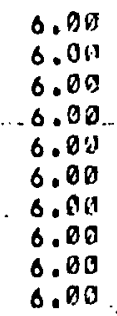 & $\begin{array}{r}84.1 \\
149.5 \\
233.6 \\
336.3 \\
457.8 \\
597.9 \\
756.8 \\
934.3 \\
1139.5 \\
1345.3\end{array}$ & $\begin{array}{l}20 \\
24 \\
25 \\
25\end{array}$ & $\begin{array}{l}.00 \\
.00 \\
.00 \\
.00 \\
.00 \\
.04 \\
.04 \\
.04 \\
.04 \\
.04\end{array}$ & $\begin{array}{l}15 \\
15 \\
5 \\
5 \\
4 \\
6 \\
2 \\
8 \\
4 \\
4 \\
4\end{array}$ & $\begin{array}{l}81 \\
55 \\
87 \\
31 . \\
89 \\
21 \\
69 \\
33 \\
39 \\
45\end{array}$ \\
\hline 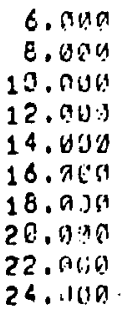 & 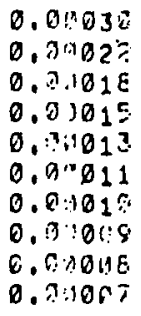 & $\begin{array}{l}7.22 \\
6.83 \\
6.55 \\
6.33 \\
6.15 \\
6.89 \\
5.87 \\
5.75 \\
5.65 \\
5.56\end{array}$ & 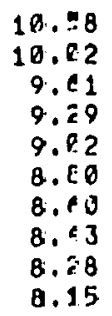 & & $\begin{array}{r}9 \\
17 \\
27 \\
39 \\
53 \\
69 \\
88 \\
289 \\
131 \\
156\end{array}$ & $\begin{array}{l}20 \\
28 \\
29 \\
31 \\
32 \\
33 \\
34 \\
35\end{array}$ & $\begin{array}{l}.0000 \\
.0462 \\
.0452 \\
.0444 \\
.9437 \\
.9431 \\
.0426 \\
.0422 \\
.0418 \\
.0414\end{array}$ & $\begin{array}{r}12 \\
13 \\
13 \\
8 \\
7 \\
6 \\
5 \\
4 \\
1 \\
3\end{array}$ & \\
\hline 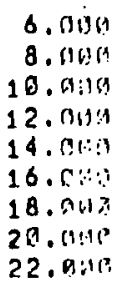 & 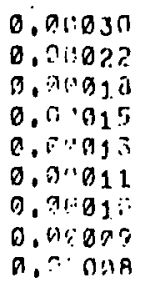 & $\begin{array}{l}7.22 \\
6.83 \\
6.55 \\
6.3 .3 \\
6.15 \\
6.90 \\
5.87 \\
5.75 \\
5.55\end{array}$ & $\begin{array}{r}10.58 \\
19.82 \\
9.01 \\
9.29 \\
9.82 \\
9.89 \\
9.07 \\
8.03 \\
F .28\end{array}$ & 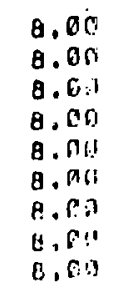 & $\begin{array}{r}199.3 \\
311.4 \\
448.4 \\
619.4 \\
797.2 \\
1969.9 \\
1245.7 \\
1507.3\end{array}$ & $\begin{array}{l}3138 \\
3364 \\
3568 \\
3747 \\
3969 \\
4958 \\
4195 \\
4324\end{array}$ & $\begin{array}{l}.9444 \\
.0431 \\
.0422 \\
.0414 \\
.0498 \\
.0493 \\
.0399 \\
.9399 \\
.0391\end{array}$ & $\begin{array}{l}17.787 \\
50.584 \\
24.677 \\
61.559 \\
85.753 \\
74.673 \\
65.183 \\
58.627 \\
52.259\end{array}$ & $\begin{array}{l}R, 4338 \\
R, 3394 \\
R, 2778 \\
R .2346 \\
R .2926 \\
2,1781 \\
R .1587 \\
2.14311\end{array}$ \\
\hline
\end{tabular}

Fig.5.2.1.1,p. 14 


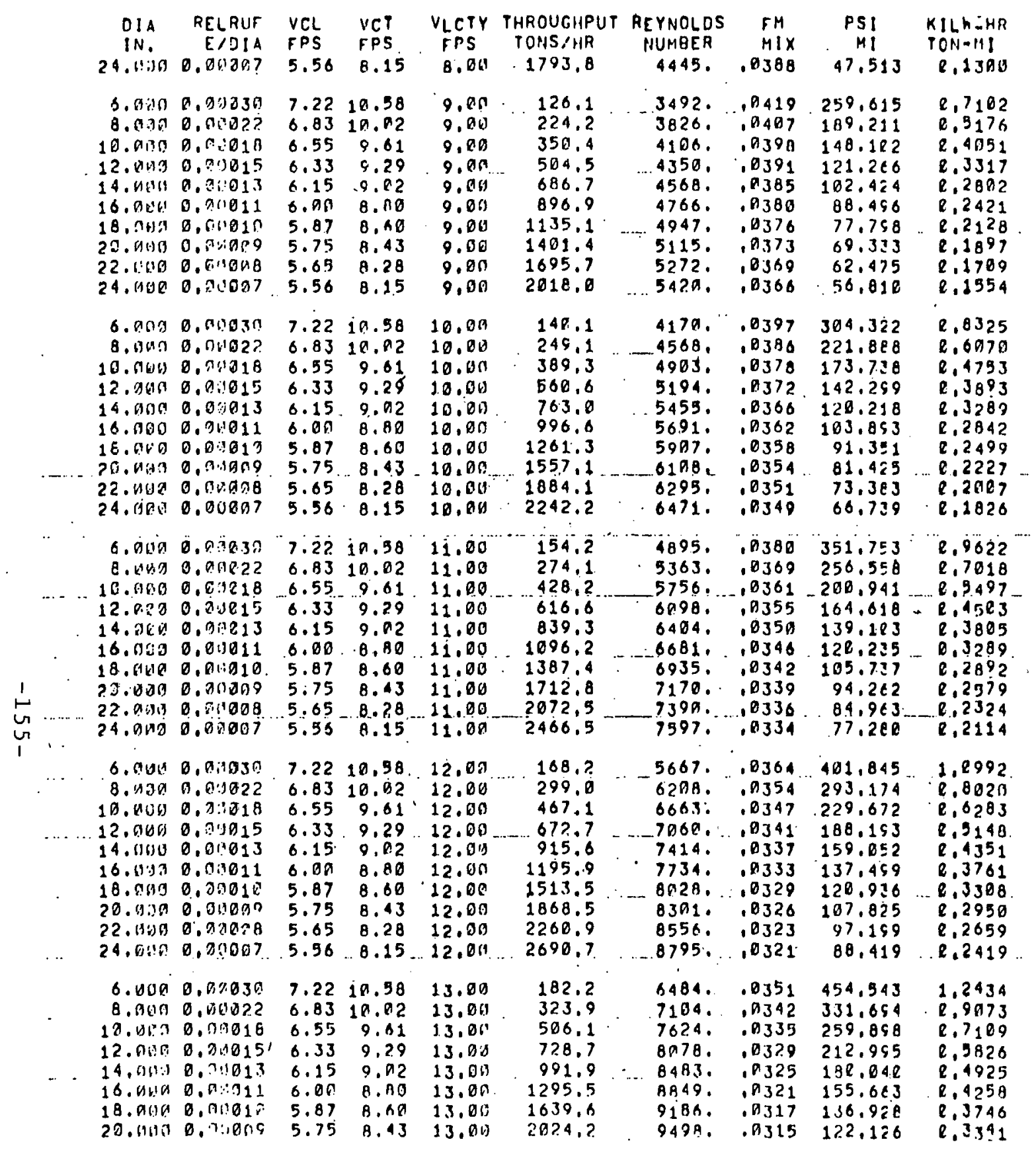

Fig.5.2.1.1,p.15 


\begin{tabular}{|c|c|c|c|c|c|c|c|c|c|c|}
\hline & $\begin{array}{r}D 11 \\
\text { IN. } \\
22.0113 \\
24.0(196\end{array}$ & $\begin{array}{r}\text { RELRUF } \\
E / D 1 A \\
0.02028 \\
0.05007\end{array}$ & $\begin{array}{l}\text { YCL } \\
F P S \\
5.65 \\
5.56\end{array}$ & $\begin{array}{l}V C Y \\
F P S \\
8.28 \\
8.15\end{array}$ & $\begin{array}{l}\text { VLCTY } \\
\text { FPS } \\
13.02 \\
13.00\end{array}$ & $\begin{array}{l}\text { THROURHPUT } \\
\text { TONS IHR } \\
2449.3 \\
2.914 .9\end{array}$ & $\begin{array}{c}\text { REYNOLOS } \\
\text { NUMAEA } \\
9799 . \\
10063 .\end{array}$ & $\begin{array}{c}F 14 \\
M I X \\
.0312 \\
.0316\end{array}$ & $\begin{array}{c}P S ! \\
M ! \\
110.120 \\
100.163\end{array}$ & $\begin{array}{l}K I L K=H R \\
\text { POH-111 } \\
R, 3912 \\
0.2740\end{array}$ \\
\hline & $\begin{array}{r}6.01010 \\
8.0110 \\
10.000 \\
12.090 \\
14.000 \\
16.000 \\
10.000 \\
20.000 \\
22.000 \\
24.0010\end{array}$ & $\begin{array}{l}0,0.0038 \\
0,00022 \\
0,00018 \\
0,00015 \\
0.01013 \\
0.01011 \\
0.00010 . \\
0,00009 \\
0,00000 \\
0,010097\end{array}$ & $\begin{array}{l}7.22 \\
6.83 \\
6.55 \\
6.33 \\
6.15 \\
6.00 \\
5.87 \\
5.75 \\
5.05 \\
5.56\end{array}$ & $\begin{array}{r}10.58 \\
19.92 \\
9.61 \\
9.29 \\
9.02 \\
8.80 \\
8.09 \\
8.43 \\
8.28 \\
8.15\end{array}$ & $\begin{array}{l}14.00 \\
14.00 \\
14.00 \\
14.00 \\
14.00 \\
14.00 \\
14.00 \\
14.00 \\
14.00 \\
14.00\end{array}$ & $\begin{array}{r}196.2 \\
348.8 \\
545.9 \\
784.8 \\
1068.2 \\
1395.2 \\
1765.8 \\
2180.0 \\
2637.8 \\
3139.1\end{array}$ & 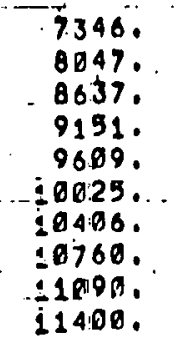 & $\begin{array}{l}.0340 \\
.0331 \\
.0324 \\
.0318 \\
.0311 \\
.0310 \\
.0397 \\
.0304 \\
.8382 \\
.0300\end{array}$ & $\begin{array}{l}509.881 \\
372.022 \\
291.550 \\
239.021 \\
202.054 \\
174.749 \\
153.711 \\
137.051 \\
123.622 \\
112.455\end{array}$ & $\begin{array}{l}45 \\
78 \\
78 \\
338 \\
328 \\
80 \\
05 \\
50 \\
581 \\
76 .\end{array}$ \\
\hline & $\begin{array}{r}6.000 \\
8.000 \\
10.000 \\
12.000 \\
14.0100 \\
16.0110 \\
18.000 \\
28.0190 \\
22.009 \\
24.000\end{array}$ & 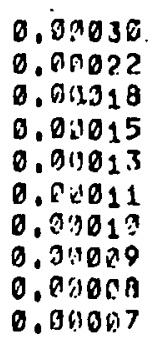 & $\begin{array}{l}7.22 \\
6.83 \\
6.55 \\
6.33 \\
6.15 \\
6.69 \\
5.87 \\
5.75 \\
5.65 \\
5.96\end{array}$ & $\begin{array}{r}10.56 \\
10.42 \\
9.61 \\
9.29 \\
9.92 \\
8.80 \\
8.48 \\
8.43 \\
8.28 \\
8.15\end{array}$ & $\begin{array}{l}15.00 \\
15.00 \\
15.00 \\
15.00 \\
15.00 \\
15.00 \\
15.00 \\
15.00 \\
15.00 \\
15.00\end{array}$ & $\begin{array}{r}210.2 . \\
373.7 \\
583.9 \\
840.8 \\
1144.5 \\
1494.8 \\
1891.9 \\
2335.7 \\
2826.7 \\
3363.4\end{array}$ & $\begin{array}{r}-82 \\
99 \\
97 \\
\ldots 202 \\
107 \\
112 \\
116 \\
120 \\
124 \\
128\end{array}$ & $\begin{array}{l}.0329 \\
.0321 \\
.0314 \\
.0399 \\
.0385 \\
.0301 \\
.0298 \\
.8295 \\
.0293 \\
.0291\end{array}$ & $\begin{array}{l}567.575 \\
414.326 \\
324.757 \\
260.216 \\
229.128 \\
194.608 \\
171.263 \\
152.7 .17 \\
137.718 \\
129.328\end{array}$ & $\begin{array}{l}26 \ldots- \\
33 \\
85 \\
63 \\
57 \\
25 \\
85 \\
78 \\
67 \\
28 \ldots\end{array}$ \\
\hline & $\begin{array}{r}6.000 \\
8.000 \\
10.000 \\
12.000 \\
14.0100 \\
16.0110 \\
18.000 \\
20.000 \\
22.0100 \\
24.000\end{array}$ & 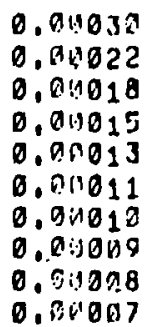 & $\begin{array}{l}7.22 \\
6.83 \\
6.55 \\
6.33 \\
6.15 \\
6.09 \\
5.87 \\
5.75 \\
5.65 \\
5.56\end{array}$ & $\begin{array}{r}19.58 \\
10.0 .2 \\
9.61 \\
9.29 \\
9.82 \\
8.80 \\
8.00 \\
8.13 \\
8.28 \\
8.15\end{array}$ & $\begin{array}{l}16 \\
16 \\
16 \\
16 \\
16 \\
16 \\
16 \\
16 \\
16\end{array}$ & $\begin{array}{r}224.2 \\
398.6 \\
622.8 \\
890.9 \\
1220.8 \\
1594.5 \\
2018.0 \\
2491.4 \\
3014.6 \\
3587.6\end{array}$ & $\begin{array}{l}9197 . \\
10075 . \\
10613 . \\
11459 . \\
12231 . \\
12551 . \\
13229 . \\
13471 . \\
13804 . \\
14273 .\end{array}$ & $\begin{array}{r}.0320 \\
.0312 \\
.0306 \\
.0301 \\
.0296 \\
.0293 \\
.0296 \\
.0287 \\
.0285 \\
.0283\end{array}$ & $\begin{array}{r}62 \\
.45 \\
35 \\
29 \\
24 \\
21 \\
18 \\
16\end{array}$ & $\begin{array}{l}74 \\
40 \\
30 \\
98 \\
14 . \\
93 \\
85 \\
24 \ldots \\
70 \\
94\end{array}$ \\
\hline
\end{tabular}

Fig.5.2.1.1,p.16 
FOUR TATA MOIITS

SLURRY: S:I IIETHACOAL (54,6\%) 3-12-77

$1 \mathrm{RC}(\mathrm{CM})$ RS (CM)

14.00000 .9421

14.0 . 0.9421

FPM DIAL

10. 15.2

20.16 .5

109. 22.3

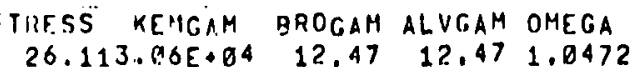

$\begin{array}{llll}26.113 .96 E+04 & 12.47 & 12.47 & 1.0472 \\ 20.336 .135+04 & 24.95 & 24.95 & 2.0944\end{array}$

$20.336 .13 E+04 \quad 24.95 \quad 24.952 .0944$

$33.061 .53 E+95 \quad 62.37 \quad 62.375 .2360$

LN(RAT(I))

4.2458

ThATIT)

$\operatorname{lin}_{4,6}(x) \operatorname{cr}(x)$

TEMP(C) $S$

5 SL TAUKLI

TAUK(I) SH

SH

YICLDIOYNES/CM/CMI

N(OMEGA) LN(STRESS)

0.0461

3.2623

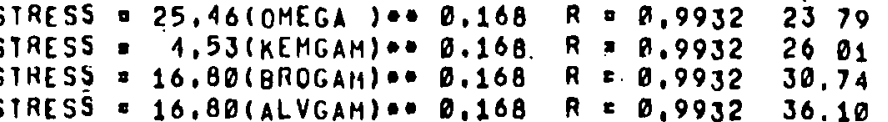

$K=16.9 \% N=0.158$ KYP $N 14.78$ NYP $=0.181$ RYP $=0.9937$

Fig.5.2.1.1,p.17 
SYSTEM PROPERTIES

MINERAL -- SSI METHACOAL $(54.6 \times)$ 3-12-77

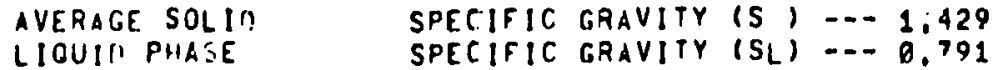

SLURFY... SPECIFIC GRAVITY (SM)

SLURRY CONCENTZATIOM BY WEIGHT

SLURAY CONCENTRATION BY VOLUME

0.1 .046

ABSOLUTE PIPEWALL RCUGHNESS (E), FEET .... O.00013000

GRAVITATIOIIAL ACCELERATICN

SLURRY TEMPERATURE (TEMP), DEGREES CELSIUS -.. 26.0

PIPE TYPE

- HORIEONTAL

PIPE. SLOPE

$\begin{array}{cr}\text { MESH } & \text { PERCENT } \\ 0.0 B 7 / 10 \% & 0.38 \\ 1110 / 206 & 13.78 \\ 2619 / 325 & 65.62 \\ 325 / P A N & 23.4 E \\ \text { TOTAL }=109.9\end{array}$

WEIGHTED MEAN DI AMETER E $9,8349 E-02$ MM COFFFICIENT OF VARIATIOV = 44.68809 SETPLING REGIME: LAFINIA

THAOUGHPUTT ITOAOSHRI SHOHT REYNOLNS NUHUER OF SETTLLING - 0.11

$G$ ROSIN - RAHMLER EDUATIONI A 100 EXP(-10/ D.068649) - 20.8.85E15)

G SLOPE $=2.585315 \ldots \ldots$..INTERCEPT B .... A.06864908340 MILLITETERS CORRELATION CDEFF. $=0.905528$ O50 $=0.06$ MILLIMETERS
KYP $=14.78$
NYF 0.181
TAUY =
2.322

SII THEORY

$P H=N_{1} A_{1}$ 


\begin{tabular}{|c|c|c|c|c|c|c|c|c|c|}
\hline $\begin{array}{l}\text { DIA } \\
\text { IN. }\end{array}$ & $\begin{array}{r}\text { RELRUT } \\
\text { E/OIA }\end{array}$ & $\begin{array}{l}\text { VCL } \\
\text { FPS }\end{array}$ & $\begin{array}{l}\text { VCT } \\
\text { FPS }\end{array}$ & $\begin{array}{l}\text { VL.CTY } \\
\text { FPS }\end{array}$ & $\begin{array}{l}\text { THROUGHPLT } \\
\text { IONS/HR }\end{array}$ & $\begin{array}{l}\text { RFYNOLOS } \\
\text { NUMBER }\end{array}$ & $\begin{array}{l}F M \\
M I X\end{array}$ & $\begin{array}{l}\text { PSI } \\
M I\end{array}$ & $\begin{array}{l}\text { KILKSHR } \\
\text { TOHI-MI }\end{array}$ \\
\hline 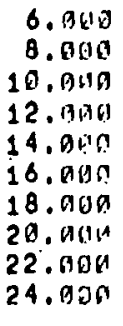 & $\begin{array}{l}0.01030 \\
0.00022 \\
0.09018 \\
0.00015 \\
0.0 .1913 \\
0.01011 \\
0.001010 \\
0.01009 \\
0.010008 \\
0.00007\end{array}$ & $\begin{array}{l}3.04 \\
2.96 \\
2.89 \\
2.84 \\
2.89 \\
2.76 \\
2.73 \\
2.79 \\
2.67 \\
2.65\end{array}$ & $\begin{array}{l}4.34 \\
4.7 .2 \\
4.12 \\
4.05 \\
3.99 \\
3.93 \\
3.89 \\
3.85 \\
3.81 \\
3.78\end{array}$ & $\begin{array}{l}4.00 \\
4.80 \\
4.00 \\
4.00 \\
4.00 \\
4.00 \\
4.00 \\
4.00 \\
4.00 \\
4.00\end{array}$ & $\begin{array}{r}50.2 \\
89.3 \\
139.5 \\
296.8 \\
273.4 \\
357.1 \\
451.9 \\
557.9 \\
675.1 \\
803.4\end{array}$ & $\begin{array}{l}3958, \\
4170 . \\
4342 . \\
4488 . \\
4615 . \\
4728 . \\
4839 . \\
4924 . \\
5089 . \\
5089 .\end{array}$ & $\begin{array}{l}.0403 \\
.0397 \\
0392 \\
.0388 \\
0384 \\
0381 \\
.0379 \\
.0377 \\
.0379 \\
.0373\end{array}$ & $\begin{array}{l}48.069 \\
35.442 \\
27.952 \\
23.084 \\
19.016 \\
17.027 \\
15.046 \\
13.464 . \\
12.176 \\
11.189\end{array}$ & 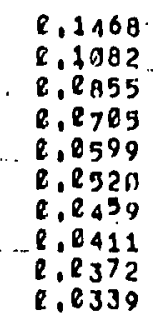 \\
\hline $\begin{array}{l}6.0140 \\
6.0109 \\
10.0010 \\
12.090 \\
14.000 \\
16.0011 \\
18.000 \\
20.000 \\
22.000 \\
24.049\end{array}$ & $\begin{array}{l}0.00030 \\
0.010022 \\
0.00018 \\
0.00015 \\
0.00013 \\
0.010011 \\
0.00010 \\
0.00009 \\
0.00008 \\
0.00007\end{array}$ & $\begin{array}{l}3.04 \\
2.96 \\
2.89 \\
2.84 \\
2.80 \\
2.76 \\
2.73 \\
2.70 \\
2.67 \\
2.65\end{array}$ & $\begin{array}{l}4.34 \\
4.22 \\
4.12 \\
4.8 .5 \\
3.99 \\
3.93 \\
3.89 \\
3.85 \\
3.81 \\
3.78\end{array}$ & $\begin{array}{l}5.00 \\
5.00 \\
5.00 \\
5.00 \\
5.00 \\
5.00 \\
5.00 \\
5.091 \\
5.00 \\
5.00\end{array}$ & $\begin{array}{r}62.8 \\
111.6 \\
174.3 \\
251.1 \\
341.7 \\
446.3 \\
564.9 \\
697.4 \\
843.8 \\
1094.2\end{array}$ & $\begin{array}{l}5939 . \\
6257 . \\
6515 . \\
6734 . \\
6925 . \\
7095 . \\
7248 . \\
7388 . \\
7917 . \\
7630 .\end{array}$ & $\begin{array}{l}.0360 \\
.0354 \\
.0340 \\
.0346 \\
.8343 \\
.0340 \\
.0336 \\
.0336 \\
.0335 \\
.0333\end{array}$ & $\begin{array}{l}60.971 \\
49.388 \\
39.013 \\
32.183 \\
27.353 \\
23.762 \\
20.989 \\
18.785 \\
16.952 \\
15.583\end{array}$ & $\begin{array}{l}R, 2045 \\
R, 1508 \\
R, 2191 . \\
2,8903 \\
2,8835 \\
2,2726 \\
2,8641 \\
R, 8574 \\
2,8519 . \\
2,0473\end{array}$ \\
\hline 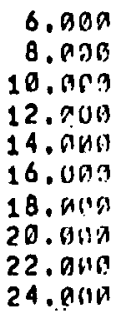 & 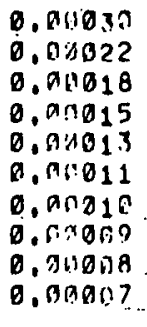 & $\begin{array}{l}3.94 \\
2.96 \\
2.89 \\
2.84 \\
2.80 \\
2.76 \\
2.73 \\
2.70 \\
2.67 \\
2.65\end{array}$ & $\begin{array}{l}4.34 \\
4.22 \\
4.12 \\
4.915 \\
3.99 \\
3.93 \\
3.89 \\
3.85 \\
3.81 \\
3.78 .\end{array}$ & $\begin{array}{l}6.09 \\
6.00 \\
6.00 \\
0.00 \\
0.00 \\
6.00 \\
6.00 \\
6.00 \\
6.00 \\
6.09\end{array}$ & $\begin{array}{r}75.3 \\
133.9 \\
209.2 \\
361.3 \\
110.1 \\
535.6 \\
677.9 \\
836.9 \\
1012.6 \\
1205.1\end{array}$ & $\begin{array}{l}8274, \\
8717 . \\
9877 . \\
9382 . \\
9648 . \\
9885 . \\
10998 . . \\
10293 . \\
19472 . \\
19639 . \ldots .\end{array}$ & 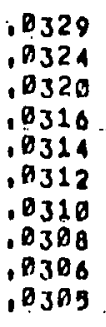 & $\begin{array}{r}86.241 . \\
65.072 \\
51.425 \\
42.489 \\
36.098 \\
31.327 \\
27.674 \\
24.772 \\
22.487 \\
20.449\end{array}$ & 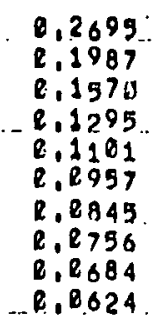 \\
\hline 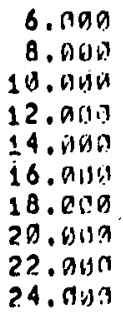 & $\begin{array}{l}0.010030 \\
0.01100 ? \\
0.010018 \\
0.00015 \\
0.00013 \\
0.019011 \\
0.011019 \\
0.00009 \\
0.010018 \\
0.09007\end{array}$ & $\begin{array}{l}3.04 \\
2.96 \\
2.89 \\
2.84 \\
2.89 \\
2.76 \\
2.73 \\
2.70 \\
2.67 \\
2.65\end{array}$ & $\begin{array}{l}4.34 \\
4.2 .2 \\
4.12 \\
4.05 \\
3.99 \\
3.93 \\
3.89 \\
3.85 \\
3.81 \\
3.78\end{array}$ & $\begin{array}{l}7.00 \\
7.00 \\
7.00 \\
7.00 \\
7.00 \\
7.00 \\
7.00 \\
7.019 \\
7.06 \\
7.00\end{array}$ & $\begin{array}{r}67.9 \\
: 156.2 \\
244.1 \\
351.5 \\
478.4 \\
624.9 \\
799.8 \\
976.3 \\
1181.4 \\
1405.9\end{array}$ & $\begin{array}{l}10091 \% \\
11538 . \\
12014 . \\
12418 . \\
12778 . \\
13083 . \\
13366 . \\
13623 . \\
13861 . \\
14981 .\end{array}$ & $\begin{array}{l}.0306 \\
.0301 \\
.0297 \\
.0294 \\
.0292 \\
.0290 \\
.0288 \\
.0287 \\
.0285 \\
.0280 \\
.0284\end{array}$ & $\begin{array}{r}111.818 \\
82,427 \\
65.118 \\
53.723 \\
45.687 \\
39.677 \\
35,052 \\
31.376 \\
28.325 \\
25.985\end{array}$ & $\begin{array}{l}R .3415 \\
R .2517 \\
R .1989 \\
R .1641 \\
R .1395 . \\
R .1212 \\
R .1970 \\
Q . R 998 . \\
R .2867 \\
R .8791\end{array}$ \\
\hline 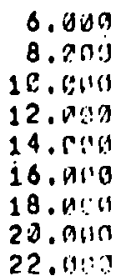 & $\begin{array}{l}0.0 .0030 \\
0.01022 \\
0.01018 \\
0.011015 \\
0.0 .01013 \\
0.0 .0011 \\
0.01010 \\
0.010019 \\
0.0 .1918\end{array}$ & $\begin{array}{l}3.04 \\
2.96 \\
2.89 \\
2.84 \\
2.80 \\
2.76 \\
2.73 \\
2.79 \\
2.87\end{array}$ & $\begin{array}{l}4.34 \\
4.2 .2 \\
4.12 \\
4.0 .5 \\
3.99 \\
3.93 \\
3.89 \\
3.85 \\
3.41 .\end{array}$ & $\begin{array}{l}8.00 \\
8.00 \\
8.010 \\
8.00 \\
8.00 \\
8.00 \\
8.06 \\
8.50 \\
0.01\end{array}$ & $\begin{array}{r}100.4 \\
178.5 \\
279.9 \\
401.7 \\
546.7 \\
714.1 \\
903.8 \\
1115.8 \\
1769 .\end{array}$ & $\begin{array}{l}13961 . \\
14709 . \\
15317 . \\
15832 . \\
16289 . \\
16679 . \\
17939 . \\
17368 .\end{array}$ & 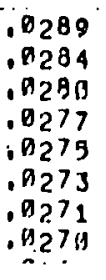 & $\begin{array}{r}137.563 \\
101.395 \\
08.083 \\
66.864 \\
56.171 \\
48.882 \\
13.114 \\
38.553\end{array}$ & $\begin{array}{l}R .4201 \\
R .3996 \\
R .2446 \\
R .2018 \\
R .1715 \\
R .1190 \\
R .1317 \\
R .1170\end{array}$ \\
\hline
\end{tabular}

Fig.5.2.1.1,p.19 


\begin{tabular}{|c|c|c|c|c|c|c|c|c|c|}
\hline $\begin{array}{c}\text { OIA } \\
\text { IN. } \\
24.0619\end{array}$ & $\begin{array}{r}\text { RELRUT } \\
\text { E/DIA } \\
0, \text { OMOST }\end{array}$ & $\begin{array}{l}\text { VCL } \\
\text { FPS } \\
2.65\end{array}$ & $\begin{array}{l}\text { VCT } \\
\text { FPS } \\
3.78\end{array}$ & $\begin{array}{l}\text { VLCTY } \\
\text { FPS } \\
\text { O.00 }\end{array}$ & $\begin{array}{c}\text { THROUGHPUT } \\
\text { TINS /HR } \\
2606,8\end{array}$ & $\begin{array}{l}\text { REYNOLDS } \\
\text { NUMBER } \\
1705 ? .\end{array}$ & $\begin{array}{c}F M \\
.111 x \\
.0267\end{array}$ & $\begin{array}{c}P S ! \\
M ! \\
31.863\end{array}$ & $\begin{array}{l}\text { KILKEHA } \\
\text { TOHIIII } \\
\text { Q.R973 }\end{array}$ \\
\hline 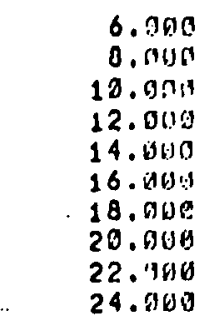 & $\begin{array}{l}0.0133 .1 \\
0.0 .1028 \\
0.27018 \\
0.32015 \\
0.01013 \\
0.00011 \\
0.00210 \\
0.01000 \\
0.00008 \\
0.00027\end{array}$ & $\begin{array}{l}3.04 \\
2.96 \\
2.89 \\
2.84 \\
2.89 \\
2.76 \\
2.73 \\
2.79 \\
2.67 \\
2.65\end{array}$ & $\begin{array}{l}4.34 \\
4.82 \\
4.12 \\
4.85 \\
3.99 \\
3.93 \\
3.89 \\
3.85 \\
3.81 \\
3.78\end{array}$ & $\begin{array}{l}9.00 \\
9.00 \\
9.00 \\
9.00 \\
9.061 \\
9.00 \\
9.00 \\
9.00 \\
9.00 \\
9.00\end{array}$ & $\begin{array}{r}113.9 \\
290.8 \\
313.8 \\
451.9 \\
615.1 \\
893.4 \\
1016.8 \\
1255.3 \\
1518.9 \\
1807.6\end{array}$ & $\begin{array}{l}17297, \\
18223, \\
18975 . \\
19613, \\
20169, \\
20664 . \\
21110 . \\
21517 . \\
21892 . \\
22248 .\end{array}$ & $\begin{array}{l}.0274 \\
.0270 \\
.0266 \\
.0263 \\
.0261 \\
.0250 \\
.0250 \\
.0256 \\
.0255 \\
.0254 .\end{array}$ & $\begin{array}{r}165.512 \\
121.945 \\
96.292 \\
79.425 \\
67.589 \\
58.664 \\
51.824 \\
46.387 \\
41.965 \\
38.388\end{array}$ & $\begin{array}{l}R .3954 \\
R .372 . \\
e .2941 \\
2.2425 \\
R .2162 \\
e .1792 \\
0.1583 \\
R .1417 \\
e .1282 . \\
8.1170 . .\end{array}$ \\
\hline $\begin{array}{r}6.000 \\
8.000 \\
13.009 \\
12.060 \\
14.009 \\
16.0110 \\
18.0193 \\
20.0001 \\
22.060 \\
24.001\end{array}$ & $\begin{array}{l}0.011030 \\
0.010022 \\
0.00018 \\
0.02015 \\
0.010013 \\
0.011011 \\
0.011618 \\
0.00009 \\
0.0 .0000 \\
0.04067\end{array}$ & $\begin{array}{l}3.04 \\
2.96 \\
2.80 \\
2.04 \\
2.80 \\
2.76 \\
2.73 \\
2.78 \\
2.67 \\
2.05\end{array}$ & $\begin{array}{l}4.34 \\
4.22 \\
4.12 \\
4.95 \\
3.99 \\
3.93 \\
3.89 \\
3.85 \\
3.81 \\
3.98\end{array}$ & $\begin{array}{l}10.00 \\
10.00 \\
10.019 \\
10.00 \\
10.00 \\
10.00 \\
10.00 \\
10.00 \\
10.00 \\
10.00\end{array}$ & $\begin{array}{r}125.5 \\
223.2 \\
348.7 \\
582.1 \\
683.4 \\
892.7 \\
1129.8 \\
1394.8 \\
1687.7 \\
2098.5\end{array}$ & $\begin{array}{l}29950 . \\
22072 . . \\
22983 . \\
23756 . \\
24429 . \\
25028 . \\
25568 . \\
26062 . \\
26516 . \\
26938 .\end{array}$ & $\begin{array}{r}.0263 \\
.0258 \\
.0255 \\
.0252 \\
.0250 \\
.0248 \\
.0246 \\
.0245 \\
.19244 \\
.0243\end{array}$ & $\begin{array}{r}195.530 \\
144.025 \\
113.717 \\
93.787 \\
79.686 \\
69.229 \\
61.121 \\
54.728 \\
49.528 \\
45.125\end{array}$ & $\begin{array}{l}e .5971 \\
e .439 B \\
e .3473 \\
R .2864 \\
e .2433 \\
e .2114 \\
e .1867 \\
2.1671 \\
e .1512 \\
2.1381\end{array}$ \\
\hline 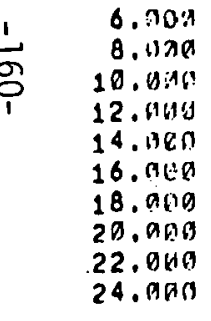 & 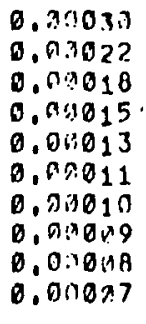 & $\begin{array}{l}3.04 \\
2.96 \\
2.89 \\
2.84 \\
2.89 \\
2.76 \\
2.73 \\
2.79 \\
2.67 \\
2.65\end{array}$ & $\begin{array}{l}4.34 \\
4.22 \\
4.12 \\
4.95 \\
3.99 \\
3.93 \\
3.89 \\
3.85 \\
3.91 \\
3.78\end{array}$ & $\begin{array}{l}11.00 \\
11.00 \\
11.00 \\
11.00 \\
11.00 \\
11.00 \\
11.00 \\
11.00 \\
11.00 \\
11.00\end{array}$ & $\begin{array}{r}138.1 \\
245.5 \\
383.6 \\
552.3 \\
751.8 \\
981.9 \\
1242.7 \\
1534.2 \\
1856.4 \\
2298.3\end{array}$ & $\begin{array}{r}24915 . \\
26249 . \\
27333 . \\
28252 \\
29053 \\
29765 . \\
30407 . \\
30994 \\
31534 \\
32036 .\end{array}$ & $\begin{array}{l}.0253 \\
.0248 \\
.0243 \\
.0242 \\
.0248 \\
.0238 \\
.0237 \\
.0235 \\
.0234 \\
.0233\end{array}$ & $\begin{array}{c}227.651 \\
167.453 \\
132.2=5 . . \\
199.022 \\
92.642 \\
88.454 \\
71.164 \\
63.603 \\
57.5: 5 \\
52.545\end{array}$ & 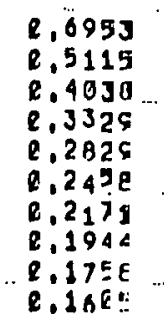 \\
\hline 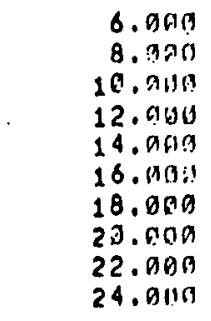 & $\begin{array}{l}0.0100 .30 \\
0.09022 \\
0.010010 \\
0.00015 \\
0.30913 \\
0.09011 \\
0.00010 \\
0.30099 \\
0.9100 .8 \\
0.00007\end{array}$ & $\begin{array}{l}3.84 \\
2.96 \\
2.89 \\
2.84 \\
2.89 \\
2.76 \\
2.73 \\
2.70 \\
2.67 \\
2.65\end{array}$ & $\begin{array}{l}4.34 \\
4.22 \\
4.12 \\
4.95 \\
3.99 \\
3.93 \\
3.89 . \\
3.85 \\
3.81 \\
3.79\end{array}$ & $\begin{array}{l}12.00 \\
12.00 \\
12.00 \\
12.00 \\
12.00 \\
12.09 \\
12.00 \\
12.010 \\
12.00 \\
12.09\end{array}$ & $\begin{array}{r}250.6 \\
267.8 \\
418.4 \\
692.5 \\
820.1 \\
1071.2 \\
1355.7 \\
1673.7 \\
2625.2 \\
2410.2\end{array}$ & $\begin{array}{l}29186 . \\
30749: \\
32919 . \\
33996 . \\
34034 . \\
34868 . \\
33621 . \\
36308 . \\
36941 . \\
37529 .\end{array}$ & $\begin{array}{l}.0244 \\
.0248 \\
.0236 \\
.0234 \\
.0232 \\
.0236 \\
.0228 \\
.0227 \\
.0226 \\
.0225\end{array}$ & $\begin{array}{l}261.794 \\
192.6: 4 \\
151.986 \\
125.221 \\
196.418 \\
92.499 \\
81.6 .7 \\
73.074 \\
66.193 \\
60.312\end{array}$ & $\begin{array}{l}R, 794 a \\
R, 5882 \\
R, 404= \\
R, 3826 \\
R, 325= \\
R .2824 \\
R, 2494 \\
R, 2242 \\
R, 2619 \\
R, 1813\end{array}$ \\
\hline 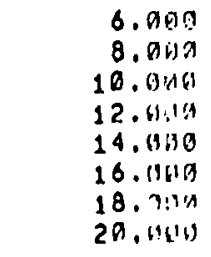 & 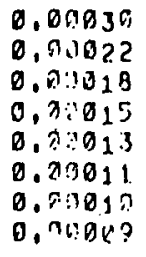 & $\begin{array}{l}3.04 \\
2.96 \\
2.89 \\
2.84 \\
2.80 \\
2.76 \\
2.75 \\
2.76\end{array}$ & $\begin{array}{l}4.39 \\
4.22 \\
4.13 \\
4.05 \\
3.95 \\
3.9 . \\
3.95 \\
3.85\end{array}$ & $\begin{array}{l}13.003 \\
13.01 \\
13.01 \\
13.06 \\
13.06 \\
13.00 \\
13.06 \\
13.01\end{array}$ & $\begin{array}{r}163.2 \\
298.1 \\
453.3 \\
652.8 \\
888.5 \\
1168.4 \\
1468.7 \\
1813.2\end{array}$ & $\begin{array}{l}33769, \\
35568, \\
37937 . \\
38282 . \\
39357 . \\
40332 . \\
41293 . \\
41997 .\end{array}$ & $\begin{array}{l}.0237 \\
.0232 \\
.9229 \\
00226 \\
.0224 \\
.9223 \\
.8221 \\
.10226 .\end{array}$ & $\begin{array}{r}298.895 \\
219.142 \\
172.8 \pm 7 \\
142.453 \\
121.830 \\
105.1 \geq 8 \\
92.818 \\
83.128\end{array}$ & $\begin{array}{l}0.9182 \\
2.0692 \\
2.927 .3 \\
2.4352 \\
2.3678 \\
2.3211 \\
2.2833 \\
2.2531\end{array}$ \\
\hline
\end{tabular}

Fig.5.2.1.1,p.20 


\begin{tabular}{|c|c|c|c|c|c|c|c|c|c|}
\hline $\begin{array}{l}\text { DiA } \\
\text { IN. }\end{array}$ & $\begin{array}{l}\text { RELRUT } \\
\text { E/DIA }\end{array}$ & $\begin{array}{l}\text { VCL } \\
\text { FPS }\end{array}$ & $\begin{array}{l}\text { VCI } \\
\text { FPS }\end{array}$ & $\begin{array}{l}\text { VLCTY } \\
\text { FPS }\end{array}$ & $\begin{array}{l}\text { THROUGHPUT } \\
\text { TONS/HR }\end{array}$ & $\begin{array}{l}\text { REYNOLOS } \\
\text { NUMBER }\end{array}$ & $F_{M I X}^{M}$ & $\begin{array}{l}P S ! \\
\text { HI }\end{array}$ & $\begin{array}{l}\text { KILWEHR } \\
\text { POH-HI }\end{array}$ \\
\hline $\begin{array}{l}22.0113 \\
24.611 .7\end{array}$ & $\begin{array}{l}0,010000 \\
0,0: 0907\end{array}$ & $\begin{array}{l}2.67 \\
2.65\end{array}$ & $\begin{array}{l}3.5: 1 \\
3.76\end{array}$ & $\begin{array}{l}13.86 \\
13.06\end{array}$ & $\begin{array}{l}2194.0 \\
2611.0\end{array}$ & $\begin{array}{l}42739 . \\
43409 .\end{array}$ & $\begin{array}{l}.0219 \\
.0218\end{array}$ & $\begin{array}{l}75.179 \\
68.628\end{array}$ & $\begin{array}{l}R .2296 \\
\text { R.2595 }\end{array}$ \\
\hline 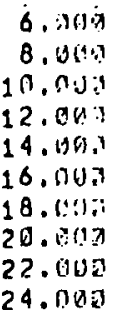 & $\begin{array}{l}0.0: 1030 \\
0.20022 \\
0.011018 \\
0.211015 \\
0.001013 \\
0.011011 \\
0.01010 \\
0.901009 \\
0.0110: 18 \\
0.01027\end{array}$ & $\begin{array}{l}3.84 \\
2.94 \\
2.89 \\
2.84 \\
2.88 \\
2.74 \\
2.78 \\
2.78 \\
2.67 \\
2.05\end{array}$ & $\begin{array}{l}4.34 \\
4.72 \\
4.12 \\
4.05 \\
3.99 \\
3.93 \\
3.89 \\
3.85 \\
3.81 \\
3.88\end{array}$ & $\begin{array}{l}14.00 \\
14.06 \\
14.06 \\
14.00 \\
14.09 \\
14.00 \\
14.00 \\
14.00 \\
14.00 \\
14.00\end{array}$ & $\begin{array}{r}175.7 \\
312.4 \\
488.2 \\
703.0 \\
956.8 \\
1249.7 \\
1581.7 \\
1952.7 \\
2362.7 \\
2811.9\end{array}$ & $\begin{array}{l}38631 . \\
49699 . \\
42389 . \\
43805 . \\
45947 . \\
46151 . \\
47147 . \\
48957 . \\
48895 . \\
49672 .\end{array}$ & $\begin{array}{l}.0230 \\
.0226 \\
.9223 \\
.0220 \\
.0218 \\
.9216 \\
.0215 \\
.0214 \\
.0213 \\
.0212\end{array}$ & $\begin{array}{r}336.381 \\
247.168 \\
194.982 \\
168.628 \\
136.423 \\
118.489 \\
194.625 \\
93.631 \\
84.653 \\
77.286\end{array}$ & $\begin{array}{l}1.8270 \\
0.7549 \\
2.5992 \\
8.4905 \\
R .4166 \\
2.3618 \\
8.3195 \\
8.2859 \\
8.2586 \\
2.23661\end{array}$ \\
\hline 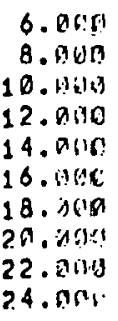 & $\begin{array}{l}0.01030 \\
0.0002 ? \\
0.001018 \\
0.01015 \\
0.01013 \\
0.01011 \\
0,04010 \\
0.010913 \\
0.010018 \\
0,00097\end{array}$ & $\begin{array}{l}3.26 \\
2.96 \\
2.89 \\
2.84 \\
2.81 \\
2.76 \\
2.73 \\
2.79 \\
2.07 \\
2.05\end{array}$ & $\begin{array}{l}4.34 \\
4.22 \\
4.22 \\
4.85 \\
3.99 \\
3.93 \\
3.89 \\
3.85 \\
3.81 \\
3.78\end{array}$ & $\begin{array}{l}15.00 \\
15.00 \\
15.00 \\
15.00 \\
15.00 \\
15.00 \\
15.00 \\
15.00 \\
15.00 \\
15.09\end{array}$ & $\begin{array}{r}188.3 \\
334.7 \\
523.0 \\
753.2 \\
1025.2 \\
1339.0 \\
1694.0 \\
2092.2 \\
2531.5 \\
3012.7\end{array}$ & $\begin{array}{l}43795 . \\
46149 . \\
48046 . \\
49661 . \\
51969 . \\
52321 . \\
53450 . \\
54481 . \\
55431 . \\
56313 .\end{array}$ & $\begin{array}{l}.0229 \\
.0220 \\
.0217 \\
.0214 \\
.0212 \\
.0211 \\
.0200 \\
.0208 \\
.0207 \\
.0208\end{array}$ & $\begin{array}{l}376.699 \\
276.668 \\
218.086 \\
179.642 \\
152.562 \\
132.467 \\
116.975 \\
104.674 \\
94.676 \\
86.392 .\end{array}$ & $\begin{array}{r}1.1504 \\
R .8449 \\
0.6059 \\
2.3480 \\
8.4659 \\
2.4045 \\
-8.3572 \\
8.3197 \\
8.2891 \\
8.2638\end{array}$ \\
\hline 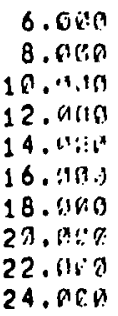 & $\begin{array}{l}0.21030 \\
9.31022 \\
0.011010 \\
0.01015 \\
0.010013 \\
0.01011 \\
0.01010 \\
0.31009 \\
2.010908 \\
0.01007\end{array}$ & $\begin{array}{l}3.04 \\
2.90 \\
2.80 \\
2.84 \\
2.89 \\
2.76 \\
2.73 \\
2.78 \\
2.67 \\
2.65\end{array}$ & $\begin{array}{l}4.34 \\
4.22 \\
4.12 \\
4.25 \\
3.29 \\
3.73 \\
3.99 \\
3.75 \\
3.81 \\
3.78\end{array}$ & $\begin{array}{l}16.00 \\
26.00 \\
16.00 \\
16.00 \\
16.00 \\
16.90 \\
16.09 \\
16.00 \\
16.00 \\
16.00\end{array}$ & $\begin{array}{r}200.8 \\
357.1 \\
557.9 \\
893.4 \\
1093.5 \\
1428.2 \\
1807.6 \\
2231.6 \\
2700.3 \\
3213.5\end{array}$ & $\begin{array}{l}49249 . \\
51887 . \\
54829 . \\
55846 . \\
57429 . \\
58837 . \\
68107 . \\
61266 . \\
62335 . \\
63326 .\end{array}$ & $\begin{array}{l}.0220 \\
.0215 \\
.0212 \\
.0209 \\
.0207 \\
.0206 \\
.0204 \\
.0203 \\
.0202 \\
.0201\end{array}$ & $\begin{array}{l}419.099 \\
3177.588 \\
242.328 \\
199.587 \\
169.488 \\
147.124 \\
129.983 \\
110.233 \\
105.123 \\
95.928\end{array}$ & $\begin{array}{l}1.2797 \\
2.9393 \\
2.7480 \\
2.6095 \\
2.5175 \\
2.4493 \\
8.3967 \\
2.3550 \\
8.3219 \\
2.2929\end{array}$ \\
\hline
\end{tabular}

Fig.5.2.1.1,p.21 


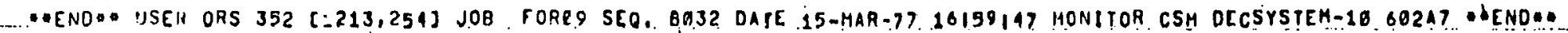

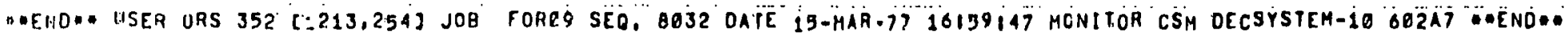

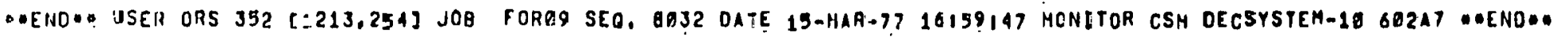

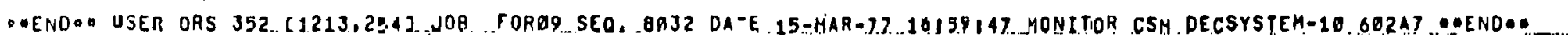

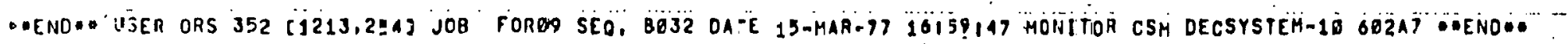

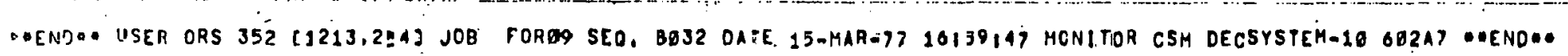

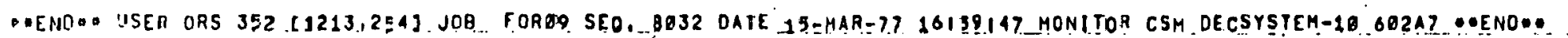

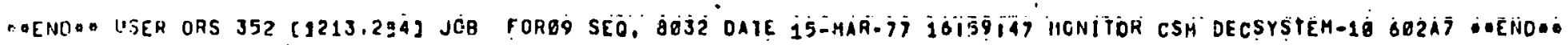

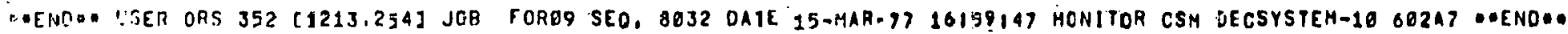

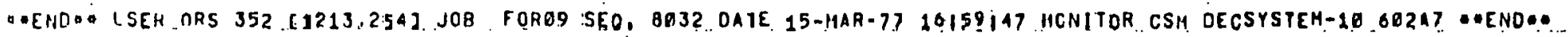

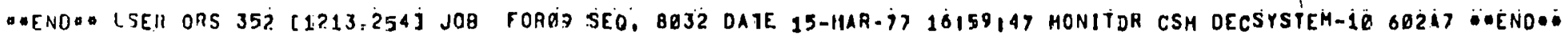

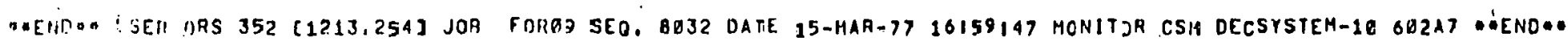

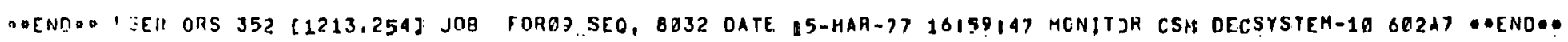

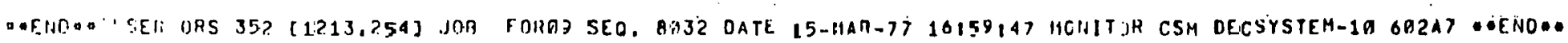


As a point of comparison, the Black Mesa pipeline transports 660 dry tons of coal per hour at $48 \%$ solids by weight at less than 6 fps in an 18" diameter pipe. Pressure drop is approximately $18 \mathrm{psi} / \mathrm{mile}$. The closest predicted methanol data point is $27.6 \mathrm{psi} / \mathrm{mile}$. for $675 \mathrm{tph}$ at 6 fps and a solids concentration of 558 by weight. Thus, the methacoal slurry does not appear to be substantially more viscous than a coalwater slurry. It does of course require considerably more power to move the greater amount of payload.

A range of pressure drops for pipe inside-diameters from 6" to $24 "$ in 2" increments is listed in Fig.5.2.1.1-1 for velocities from 4 to 16 fps in 1 -fps increments. Pipe roughness is assumed to be that of new commercial steel $(0.00015 \mathrm{ft})$.

The slurry is essentially a nonsettling or homogeneous slurry for minus-100 mesh coal but it is on verge of settling. Thus a coarser particle size is likely to produce a settling slurry. Thus, the experiment has produced. two very significant pieces of information, both of which are important in the economics of slurry pipelining - carrying capacity and coarseness limit.

\subsubsection{Importance of Carrying Capacity}

The carrying capacity of the coal is important for the several reasons which are discussed below.

\subsection{Reduction of Methanol Con- version Loss}

The greater the carrying capacity of the methanol, the smaller is the total system energy loss to the methanol conversion process. Coal can be converted to methanol at only 40 to $50 \%$ efficiency. However, if the slurry itself is recognized as a fuel and compared to pure methanol, then the conversion loss is only taken on the portion converted to methanol, and that loss can be spread over the entire mixture. 
Consider, for example, a slurry which is two-thirds coal and one-third methanol, the coal being $60 \%$ carbon and $30 \%$ moisture. Then a ton of coal yields about 3200 lb ot methanol, which in turn transports $6400 \mathrm{lb}$ of coal. The loss of the additional ton of coal that is consumed in the conversion process can now be charged to the full $9600 \mathrm{lb}$ of fuel delivered to the power plant. The overall conversion efficiency of the process is

$$
\frac{9600}{9600+2000} \times 100=838
$$

If the carrying ratio is increased from two to three, the overall conversion efficiency increases to $86 \%$.

This conclusion is sufficiently important to merit repetition. While the direct conversion efficiency of coal to methanol is at most $50 \%$, the equivalent efficiency of conversion for the entire system potentially approaches $90 \%$. It will be seen in section 5.2.1.3.2 below that this efficiency can be further increased, possibly exceeding 908 .

\section{2 .1 .2 .2 Reduction of System Water Requirement}

The ton of coal, which in the above example is converted to methanol, requires about $3000 \mathrm{lb}$ of water for conversion, if the natural moisture in the coal can be used in the process, and yields about 3200 lb ot methanol. 'lhe carrying capacity of this 3000 lb of water, after its conversion to methanol, may be compared with the carrying capacity of an equal amount of water at Black Mesa, where 52 lb of water carries 48 lb of coal. For a slurry which is two-thirds coal; the $3200 \mathrm{lb}$ of methanol carries 6400 ib of coal. But the $3200 \mathrm{lb}$ of methanol itself is equivalent, on a heating-value basis, to approximately the same amount of coal, so that the equivalent of $6400+3200=9600 \mathrm{lb}$ of coal is carried by $3200 \mathrm{lb}$ of methanol. At Black Mesa, the same 3000 1b of water entering the system carries 


$$
3000 \times \frac{48}{52}=27691 \mathrm{~b} \text { of coal }
$$

Now consider the removal of water from the coal-water slurry. In Report HCP/M-1171-2 of this series (see Table 1.1), it was seen that at the Mohave Generating Station, 1,176,000 Btu/ton are required to separate the coal and water and dry the coal to the contract moisture value of $10.74 \%$. About $1,420,000$ Btu would be required to yield bone-dry coal, which for the coal used in the preceding numerical examples (not the same as Black Mesa coal) would be equivalent to $166 \mathrm{lb}$ of coal consumed.

In the case of the methanol slurry, of the $50 \%$ energy lost in conversion, it seems reasonable to expect that some can be used, at low-grade waste heat from the process, to dry the incoming coal. Therefore, it is not necessary to again charge the methanol system with the energy loss in obtaining dry coal.

Thus, for the water system, $2769 \mathrm{lb}$ of coal and $3000 \mathrm{lb}$ of water enter the system, and $2769-166=2603 \mathrm{lb}$ of dry coal eventually appears in the power plant boiler. The transportation efficiency may then be said to be

$$
\frac{2769-166}{2769}=94.08 \text {. }
$$

With the one-third - two-thirds methanol system, along with the $3000 \mathrm{lb}$ of entering water, there is a ton of coal to be converted, $a$ ton to be lost, and $2 \times 3200=6400 \mathrm{lb}$ to be transported. That is, 10,400 $1 \mathrm{~b}$ of raw coal enter and the equivalent of $9600 \mathrm{lb}$ of dry coal emerge, for a transportation efficiency of

$$
\frac{9600}{10,400}=92.33 \text {. }
$$

The advantage of methanol as a slurry carrier may now be portrayed as the ratio of its carrying capacity to that of water, i.e., 


$$
\begin{aligned}
& 10,400 \times 0.923 \\
& 2769 \times 0.940
\end{aligned}=3.7 \text {. }
$$

For the one-fourth - three-fourths methanol system, the advantage is

$$
\frac{12,800 \times 0.941}{2769 \times 0.940}=4.6
$$

The foregoing example was based upon using the natural moisture in the coal, which was taken as $30 \%$, or $600 \mathrm{lb} / \mathrm{ton}$. If none of this moisture is used, the ratios calculated above must be reduced by $3000 / 3600=0.833$, becoming 3.1 and 3.9 respectively.

A highly important conclusion emerges. The water requirement for the methanol slurry may be three to four times less than that for the water slurry.

In the foregoing discussion, methanol and coal have been treated as equivalent fuels. For the present illustrative purpose, this approach is adequate because the heat contents are approximately the same. More precise calculations would be done on a heat content basis for coals of a specific proximate analysis and for methanol produced by a specific process from that coal.

Clearly, the water problem for the methanol line is greatly less than for the water line. In particular, the use of a return line becomes very interesting when it is only required to accommodate such a small return fraction. It may be further noted that, once it is decided to install the return line, system flexibility is increased. For example, it is no longer necessary to locate the methanol plant at the head of the line; it can be placed at any location along the line where other factors, e.g., existing labor force, availability of cheap power, proxim- 
ity to other markets for the methanol, etc., are located. However, as will be seen in section 5.2.1.3.2 below, there are good reasons for having the metharol plant at the pipeline head end.

\subsubsection{Benefits of Dry Coal}

If the coal entering the slurrifier at the head of the pipeline is completely dry, a number of benefits accrue. Some of these would be realized in the pipeline operation, and some in the power plant. They are discussed below, in reverse order.

\subsection{Effects of Moisture upon Power Plant Efficiency}

Any moisture that enters the furnace must be evaporated, and the latent heat of vaporization thereby absorbed is denied to the power conversion process. For example, if the coal is $30 \%$ moisture as in the foregoing example and as is the case with much Western coal, then approximately $350 \mathrm{Btu} / \mathrm{Ib}$ of coal input is required to vaporize the moisture, representing an energy loss of about $4 \%$ for most Western coal.

Now, it is not possible to avoid taking this loss somewhere between the mine mouth and the power plant stack. In principle, this latent heat, along with that of the water formed during combustion, could be recovered by installation of sufficient preheater surface to cool the stack gas below the boiling point. In practice, this is not done because condensing moisture combines with the sulfur dioxide and other stack gases to form acids. The process is complex, and heat recovery in the preheater is generally limited to about $300^{\circ} \mathrm{F}$. However, the less moisture in the gas, the lower the temperature to which the stack gas can be economically cooled. And since $30^{\circ} \mathrm{F}$ in additional stack gas cooling is worth approximately a 18 increase in efficiency of the power plant, the availability of bone-dry coal should have some value by enabling a small increase in power plant efficiency. 


\subsection{Effects of Moisture on Pipeline Operation}

It one now examines the entire mine-pipeline-power plant complex as an integrated system, it is seen that drying the coal along with the methanol conversion process offers several attractions. First, of course, is the possible increase in power plant efficiency just discussed.

There are three large additional benefits which accrue to the pipeline operation from the use of dry coal. The first benefit derives from the increase in pipeline efficiency because it is no longer necessary to transport the water. For Western coals, which generally have high moisture content, this benefit can be very large. Again using the example of coal which has a $30 \%$ moisture content, the efficiency of the pipeline is increased by almost $50 \%$ if the coal is dried at the head of the line. If the raw coal is only $20 \%$ moisture, the pipeline efficiency is still increased $25 \%$ by drying. This increase is realized as a direct percentage increase in the number of Btu transported per Btu consumed in the transportation process.

The second benefit of drying lies in the turther reduction of the system water requirement, as was seen in the discussion of water requirements in section 5.2.1.2. The third benefit from drying the coal lies in the possibility of obtalning the drying energy from the methanol conversion process, as was also assumed in the discussion of section 5.2.1.2.1 above. As noted there, the methanol conversion process is very inefficient, being estimated at $41 \%$ (Ref. 28) to 50\% (Ref. 29). Most of this inefficiency appears in the form of waste heat. If this otherwise wasted heat is used to dry the coal to be shipped, then that same amount of energy becomes available as sensible heat to the power plant energy conversion cycle instead of being lost as latent. heat in the boiler. It is as though low-grade waste heat from the methanation plant were transported without coat and transformed into high-grade heat at the power plant, in defiance of the second law of thermodynamics. 


\subsubsection{Methanol Consumption and Marketing Options}

At the pipeline terminal, many options arc available for lealizing the value of the methanol.

1. The slurry may be burned directly as a fuel in power plant boilers.

2. The slurry may be separated into powdered coal and alcohols which, in turn, provide fuel for several applications. The suboptions include:

2.1 Powdered coal, after separation from the slurry, may be used as feed stock for low-BTU gas plants in areas where water for the gasification is available, or for synthetic natural gas plants or ammonia plants.

2.2 The alcohols may be returned, by a second pipe laid alongside the main line, to the head end of the pipeline. As has been seen in sections 5.2.1.2.1 and 5.2.1.3.2, the return line for methanol only needs a fifth or a sixth of the capacity that would be required for a water slurry.

2.3 The alcohols may be marketed as fuel-grade methanol for stationary engines. The market could include natural gas supplement, replacement for propane or butane, gas turbine fuel, additive to gasoline fuel, or used directly as fuel in engines for automotive and industrial applications:

2.4 The alcohols may be marketed as vehicular fuel. If one looks ahead to the time, early in the next century, when petroleum can no longer supply most of the vehicular fuel requirement, there appear to be two preeminent candidates for liquid, vehicular (ultimate) fuels: methanol and hydrogen. There are, of course, many problems and obstacles to the adoption of either of these, which means that a great deal of research and development will be necessary to bring either concept to fruition. The use of methanol in the pipeline in the nearer term offers the opportunity to find early answers 
to many of the questions relative to its potential as the ultimate vehicular fuel. That is, the principal objectives of two R\&D programs can be accomplished by funding only the smaller, more immediate of the two. Moreover, should a methanol pipeline be built, it would constitute a part of the demonstration program for the ultimate fuel.

\subsection{The alcohols separated from slurry may be further} separated into the basic constituents for subsequent marketing. These could include: methanol, ethanol, n-propanol, and i-butanol.

3. The slurry can be used directly as pipeline fuel. When burned in'a gas turbine with a bottoming engine, the overall efficiency of the pumping process would then be approximately $50 \%$ greater than that of the electrically driven prime movers. The direct use of the slurry as prime mover fuel would render the slurry pipeline the most energy-efficient of all coal transportation modes insofar as the consumption of mechanical energy of movement is concerned. When these two factors are combined in a system design and subjected to economic analysis, it may well be that the methanol-coal slurry is overall the most energy-efficient mode of long-distance coal transport.

These simple figures are quoted only to show the promising potential of the concept. As has already been stated, it is strongly recommended that further research be performed. Specific recommendations are presented in Report HCP/M-1171-1.

\section{2 .3 problem Areas}

It is necessary to recognize disadvantages compared to other approaches, potential pitfalls, limitations, technological uncertainties, and economic constraints. 
The brevity with which these factors are treated here is no indication whatever of their anticipated severity. The future work which is being recommended here should begin with a quantitative, in-depth treatment of these factors. The present purpose is to identify potential opportunities, not to assess them in depth. Accordingly, brief mention will be made of only two particularly sensitive questions.

\section{2 .3 .1 Safety}

Present-technology coal slurry pipelines, i.e., water-coal slurry, appear to be far safer than any other mode of long-distance coal transport, partly because the water-coal slurry is not flammable. Methanol-coal slurry, of course, does not possess this attraction. However, since it is still far less flammable than some of the fluids presently moved by commercial pipeline, flammability is certainly not a barrier to the introduction of methanol-coal slurry pipelines. However, the safety implications of this new application must be examined.

\subsubsection{Environmental Impact}

Although it has not been analyzed, the environmental disruption resulting from a methanol-coal slurry pipeline spill is almost certain to be more undesirable than that from a water-coal slurry. However, the consequences appear to be much less undesirable than some fluids which are presently moved all over the country by pipeline. Therefore, it seems unlikely that environmental impact will prove to be a decisive negative factor in the competition. Nevertheless, that impact must be examined.

\subsection{Slurry-fired Engines}

To utilize coal-water slurry as a fuel for engines, it is customary to first dewater the slurry and then utilize the dry, pulverized coal for firing in the engine. Two different systems have been used in the united States to dewater 
and dry coal at the terminus of the coal pipeline. The original Consolidation coal pipeline in Ohio used disk filters followed by flash dryers. The Black Mesa line uses centrifuges mounted directly on top of the pulverizer, and the centrifuge cake is dried in the pulverizer. One other method is the direct combustion of a concentrated, stabilized coal slurry in a cyclone burner. This was done only experimentaliy, but the test was successful.

Dewatering facilities generally produce environmental effects similar to those of the coal preparation area and, for the most part are similarly solved. One exception is the disposal of water from the slurry stream. Water treatment may or may not be required, depending on intended use of the water. Normally a coal slurry pipeline can be expected to supply a steam power plant. In this case, effluent from the dewatering facility can be used as a part of the cooling water makeup. If the water is used for boiler feed water, treatment is generally required.

The major problems involved in burning pulverized coal in internal combustion engines will be discussed later in para. 6.1 . For the reciprocating engines they would primarily involve metering, combustion, deposits, and wear. For open cycle gas turbines, hot corrosion and erosion resulting from high sulfur and ash content of most coals are the principal problems.

i'he severity of the problems is dependent to some extent on the source and analysis of the coal used. There is a wide variety of coal mined in the United States (see l'able 5.3-1). Fixed carbon ranqes from $40 \%$ to $96 \%$, calorific values from 9300 to $15,700 \mathrm{Btu} / \mathrm{Ib}$ and ash content from $4 \%$ to $22 \%$. Some of the coals, particularly those in the Midwest, are high in sulfur content, creating difficult air pollution problems.

Little is known about the ignition quality of coal as compared to conventional liquid fuels used in internal combustion 
Zable 5.3-1 Sources and Analyses of Various Ranks of Coal

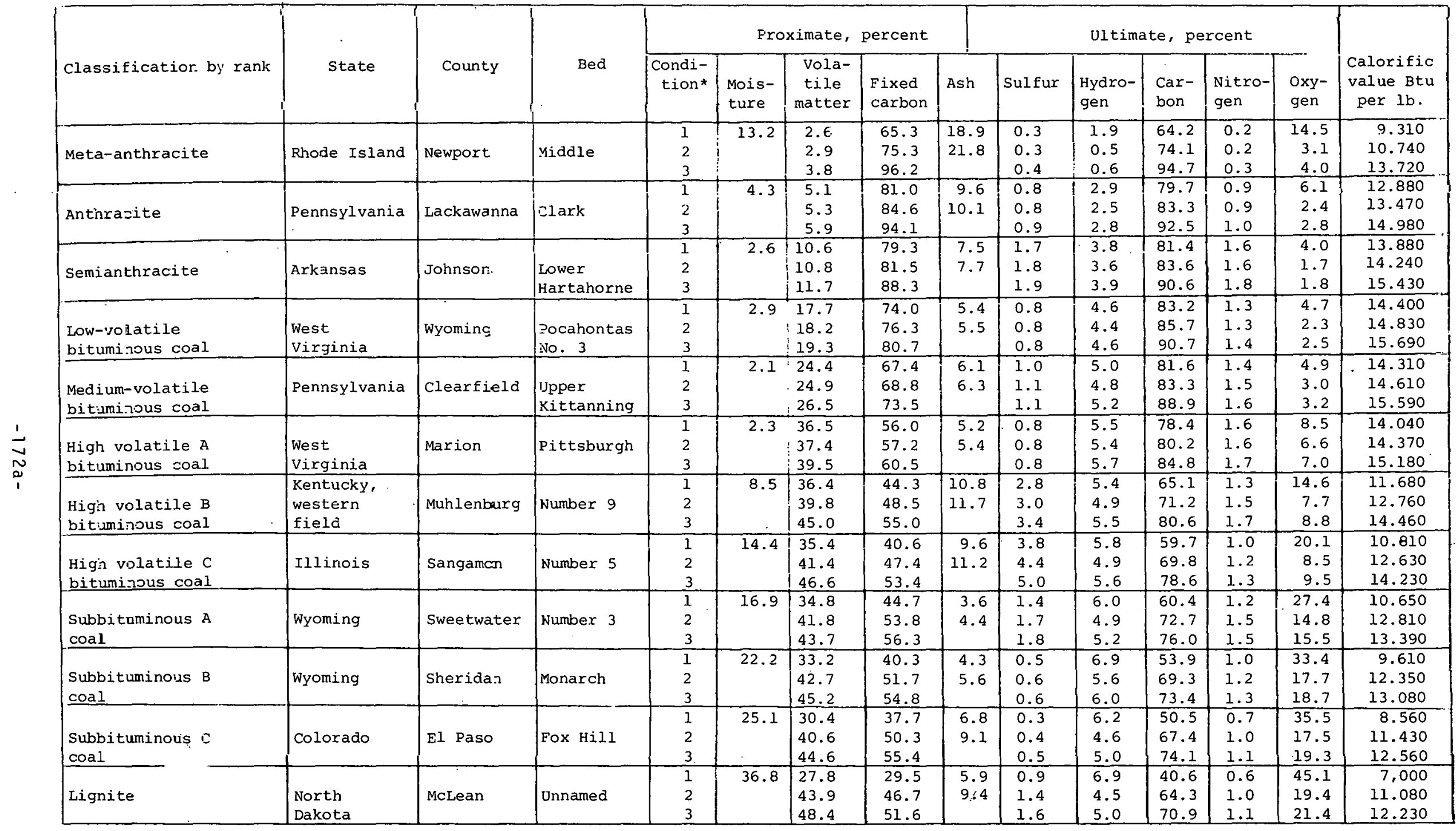

*1, sample as received; 2, moisture-free; 3, noisture and ash-free 
engines. This could be an important factor, particularly in Otto cycle and diesel engines, wherein the basic engine design (compression ratio, ignition or injection timing, etc.) is largely influenced by the fuel properties. Ignition quality is largely dependent on the particle size and volatility of the coal used. It is known from past work that ignition quality and burning rate improve as particle size decreases. Particle sizing, however, has not been reported in enough detail to clearly identify the sizes needed for optimum combustion characteristics. Work needs to be done not only in this area but also to identify the chemical mechanisms by which ignition is initiated. The effort should also include a determination of whether the process of pulverizing changes the chemical as well as the physical properties of coal.

The concept of methanol-coal slurries introduces new possibilities and considerations with respect to utilization as fuel in engines. One approach is to burn the slurry as fuel in its as-received condition. This should definitely be feasible in Rankine cycle and other external combustion engine power plants. It may be feasible in gas turbines, although problems of corrosion and erosion could result from the coal constituents of the fuel, depending on the particular type of coal used. Using a methanol-coal slurry as fuel in reciprocating engines would be highly questionable because of the inherent difficulties associated with burning coal in these engines, as previously described.

The other approach is to separate the pulverized coal from the methanol to provide fuel for different applications. The use of pulverized coal in various types of engines will be discussed in more detail later. A discussion of using methanol as fuel follows.

\subsubsection{Reciprocating Engines}

Methanol has some significant advantages as a gasoline engine fuel. It burns much cleaner than petroleum 
fuels or even natural gas. It is a more flexible fuel than gasoline, permitting wider deviations from ideal fuel-alr ratius. Although the net heat of combustion of methanol (8550 Btu/lb) is only about half that of gasoline, engines burning methanol can be made more efficient than gasoline engines. Compression ratios can be increased to take advantage of methanol's higher flame speed and good antiknock properties. Because it burns cleaner than gasoline, fewer emission control devices are needed. Since it burns cooler and has a cooling effect as it evaporates in the cylinders, cooling systems can be smaller and consume less power (Ref. 31). It is completely mixable with gasoline in concentrations up to about 15\%, an advantage which Lacilitates its use as a gasuline additive. The addition of $15 \%$ methanol to most motor gasolines increases the Research Octane Number (RON) significantly and the Motor Octane Number (MON) slightly. For example, with a typical unleaded gasoline having a RON of 93 and a MON of 84 , the addition of $15 \%$ methanol having octane blendiny values of 120 nON and 91 MON would increase the octane numbers of the gasoline-methanol blend to 97 RON and 84 MON (Ref. 32).

Methanol has some disadvantages as well. One of its most serious problems associated with methanol-gasuline mixtures is phase separation, which relates to the questiun of fuel stubilily. Because of methanol's polar character, its solubility in gasoline is limited to about 15\%, as indicated earlier. However, the phase separation problem becomes critical when the blend contacts even very small quantities of water. Rapid phase separation occurs, with the polar water-methanol phase settling out at the bottom. Gasoline containing methanol would therefore have to be stored and distributed under anhydrous conditions, which would be difficult and expensivé. As an alternative, it might be possible to hlend alcohol with gasoline at the pump, but this would also be expensive and require special equipment. Another problem with methanol is the possibility of vapor lock occurring in the engine fuel system. 
The addition of methanol to gasoline considerably increases the volatility of the fuel. If current gasoline vapor pressures were to be maintained, the use of $15 \%$ methanol blends would require removal of all the butanes and a significant fraction of the pentanes. A further potential disadvantage of using methanolgasoline blends is the possible adverse effect on road performance of vehicles. Because of emission controls, most new cars are already carbureted near the lean limit for satisfactory performance, and additional leaning by methanol may tend to compound this problem. The wider flammability limits of methanol may partially compensate for the leaner carburetion, but the problem would still exist.

Essentially the only engine applications to date for methanol have been in racing cars and boats and in piston engine aircraft where it was injected directly into manifolds for added takeoff power. Some experimental testing has been conducted with methanolgasoline blends during the past three years in late model and older model passenger cars, and the results suggest that in the area. of fuel economy and emissions the benefits are only significant in the case of the older cars which operated with rich carburetor mixtures before emission control standards were imposed.

Burning of methanol in diesel engines presents a considerably more difficult problem than in gasoline engines. The high octane number of methanol, which is an advantage in a gasoline engine, is a detriment in a diesel engine because the ignition delay (a function of the cetane number of the fuel) with methanol is much greater than with diesel fuel. A very high compression ratio, or an auxiliary means of ignition, would be required to properly ignite methanol in a compression ignition engine, particularly for starting and under idling or light road conditions. This would cause some complications in the engine design and no doubt result in greater cost as well as inaintenance. Another potential problem would be more rapid wear in the fuel injectors because of the low lubricity of methanol. With some development effort it may be 
possible to adapt diesel engines to run on blends of methanoldiesel fuel, but the only apparent advantage would be to conserve a small percentage of diesel fuel, and it is questionable whether the compromises involved in engine design and performance would be worthwhile.

\subsubsection{Gas Turbines}

Methanol has excellent characteristics as a gas turbine fuel, primarily because of its clean burning characteristics which result in a lower level of harmful emissions and should help to ensure long component 1 ife and low maintenance. With its continuous combustion process the turbine is not subject to the limitations of reciprocating engines with regard to ignition quality.

The potential of coal-derived methanol as a substitute fuel for natural gas and petroleum-derived liquid fuel for gas turbines provided the incentive for a recent joint test project by AMAX, Inc., Turbo Power and Marine, and Florida Power Corp. (FPCo) (Ref. 33). A 12.5-hr run on methanol was conducted at one of FPCo's gas turbine generator installations. The power plant was converted to a dual fuel configuration, both to allow direct comparison with standard fuel oil and to provide gas assist starting on methanol and No. 2 oil. The only other engine modification was addition of a piston pump at the fuel supply to provide lubrication of the engine fuel pump.

Engine performance on methanol was reported to be excellent. Acceleration was normal, and steady state running was even more stable than on No. 2 fuel. Burner can temperature patterns were the same as when burning Jet $A$ or No. 2, and there was little carbon buildup on the nozzles. Test data for $\mathrm{NO}_{\mathrm{x}}$ emissions while burning methanol (Fig. 5.3.2-1) showed that, over the power range tested, emissions were 74 \% less than with No. 2 oil. CO emissions were somewhat higher with methanol than with No. 2 fuel, exceeding the projected EPA limit at loads higher than $15 \mathrm{MW}$ (Fig. 5.3.2-2). However, the whole question of meeting proposed regulations is somewhat academic at present, because the regulations have not yet been promulgated. 
From this and other programs (AMAX is also working with General Motors on vehicular turbine tests), it is concluded that methanol has excellent potential as a turbine fuel, provided it can be produced at a price competitive with petroleum-based turbine fuel. With coal-derived methanol, this appears to be a distinct possibility.

\section{3 .3 Boilers}

The potential of methanol as a fuel for industrial boilers appears to be equally as good, if not better than, for gas turbines. Modifications should for the most part be confined to fuel pumps and burner nozzles to handle the larger volume of methanol required for providing the same output as regular fuel oil. With the continuous combustion process and a clean burning fuel, control should be relatively simple, and maintenance should be low. 


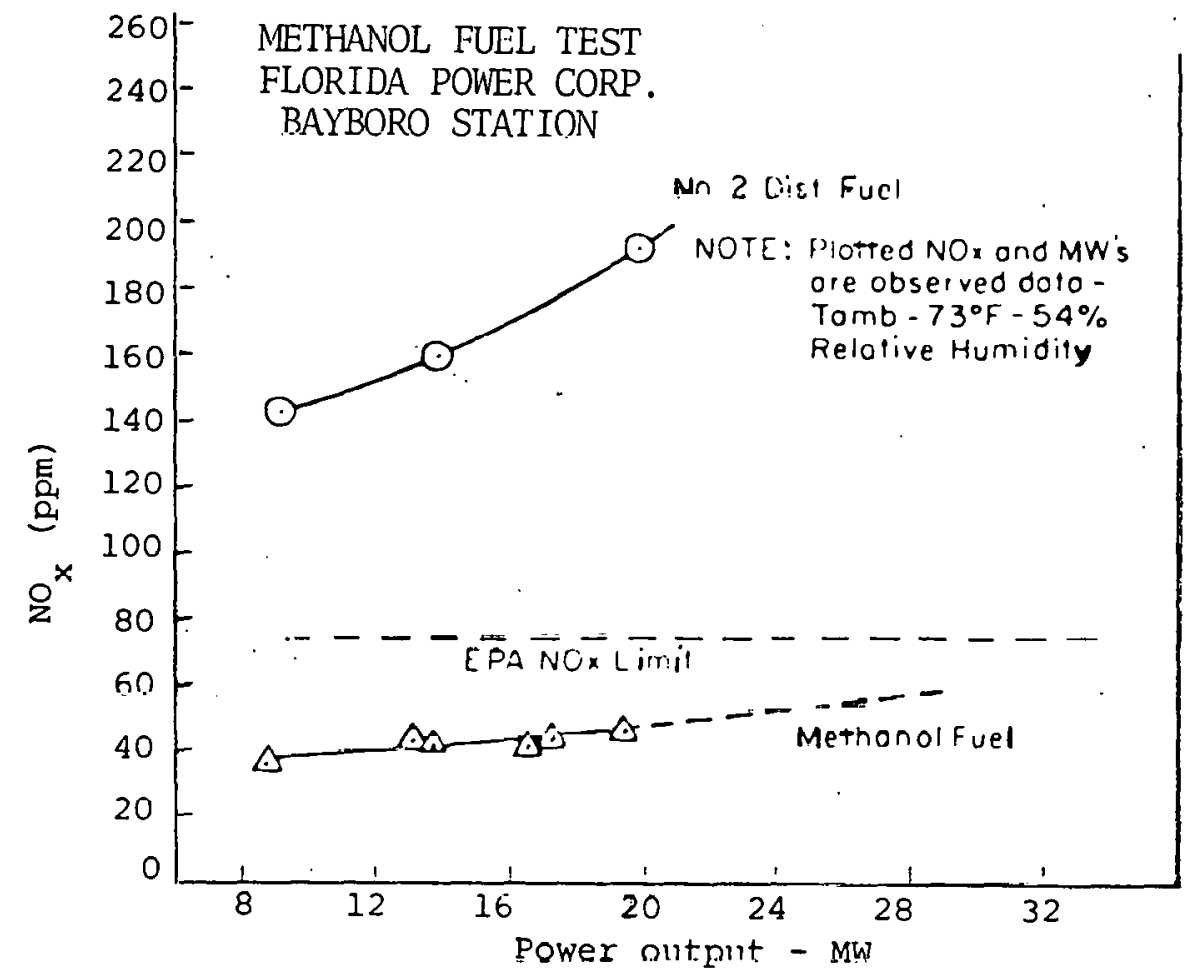

Fig. 5.3.2-I - $\mathrm{NO}_{\mathrm{x}}$ Emissions - Gas Turbine Test with

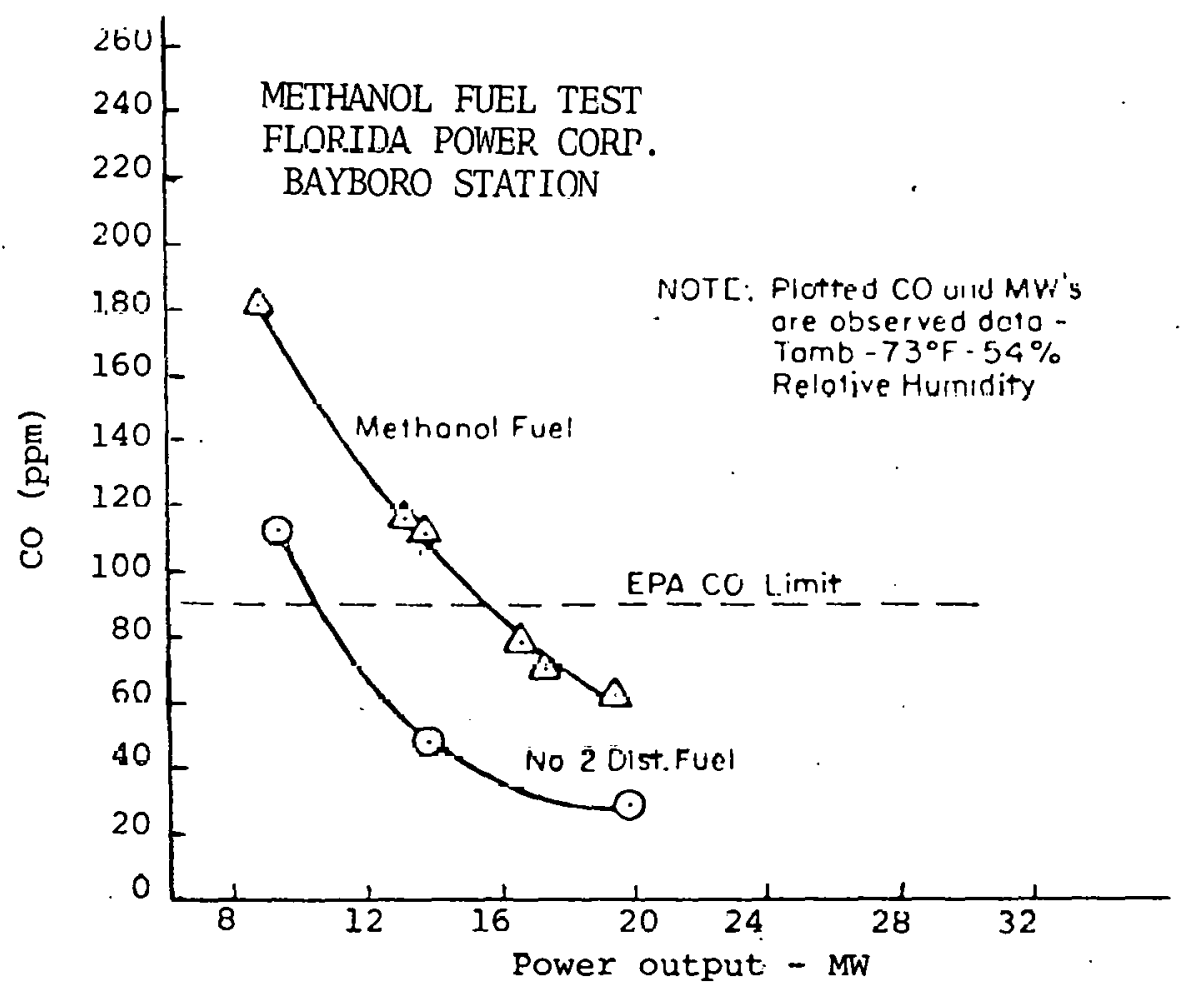

Fig. 5.3.2-2 - CO Emission - Gas Turbine Test with Methanol Fuel

Source: Reference 33 


\subsection{SUBSTITUTION OF COAL FOR PETROLEUM AND GAS IN PIPELINE OPERATIONS}

The President's energy goals for the 1977-78 period, as stated in his message to Congress in April 1977, place heavy emphasis on both energy conservation and increased production and use of coal. Since coal is the Nation's most abundant energy resources, the President is thereby relying on coal to replace oil and natural gas for many industrial fuel applications. One of the major goals is to increase coal production by more than two-thirds, from 665 million tons in 1976 to more than 1 billion tons by 1985. Electric utilities are being pressed not only to use coal for their new power plants but also to convert existing oil and gas-fired generators to coal. The same philosophy applies to other industries that consume power, including the pipeline industry. The issues being addressed in this study of energy consumption in pipeline transportation systems must therefore include not only efficiency improvements in pipeline drivers using conventional gas and petroleum fuels but also methods of burning coal in those power plants.

The conversion of coal into synthetic fuels presents difficult economic problems. At present it is estimated that synthetic liquid petroleum, using the best available processes, would have to sell for about $\$ 20-25 / b b l$, which is nearly double the world price of crude oil. It is also estimated that, based on current technology, it would cost about $\$ 35$ billion to build the coal liquefaction plants needed to replace only $10 \%$ of today's total petroleum consumption. Production of synthetic gas from coal is likewise not yet economically practical. Processes now being tested in pilot plants would require a price at least twice as high as the free market price of natural gas produced and sold within the same state; and three to four times higher than the government-regulated price for natural gas sold interstate. To build a commercial gasification plant capable of processing more than 15,000 tons of coal a day, it is estimated that the cost would be as much as $\$ 1$ bllilon ( $R \in f .34)$. 
ERDA, shortly after its creation in January 1975, moved toward the implementation of large demonstration projects for coverting coal to clean fuels. The conversion and use of coal was given high priority in ERDA's National Energy Plan, issued in April 1976. DOE (and its fore runner ERDA) to date has defined several demonstration projects for translating advanced concepts into commercial use. One, a clean boiler fuel plant, is now under way, with the award of a $\$ 237$ million contract to the Coalcon Co. in 1975. The others include a pipeline quality gas plant aimed at industrial and commercial heating, and a fuel gas plant for electric power utilities or industrial uses. Industry cost sharing is concentrated in the more advanced phases of coal conversion, although there is some industrial cofunding in earlier developmental stages (Ref. 35).

DUE's coal conversion and utilization effort is directed toward demonstrating second-generation technology on a near commercial scale in the early 1980's. A variety of processes is being developed to convert Eastern and Western coal to liquids and gases. Coal utilization programs are directed toward development of processes to permit increased use of coal by direct combustion, with the objective of developing and demonstrating on a commercial scale the direct combustion of high-sulfur coal without exceeding pollution standards. Fluidized bed combustors containing sulfur oxide sorbents will be used in the burning of coal. This direct combustion technology is considered to have near-term (1985) potential as an alternative to existing boiler systems that use scrubbers for emission control.

While the coal conversion and utilization efforts in DOE's Fossil Energy program discussed above have potential benefits in the overall spectrum of power generation, there are alternative approaches which could have significant benefits more directly related to the pipeline industry. One of these is discussed in para. 4.3.6 of this report concerning pipeline application of fuel cells, in which the potential application of fuel cell powered DC 
motors is described. Another concept which merits consideration is the direct utilization of pulverized coal in liquid pipeline drivers with the coal brought to the pumping station in the form of slurries.: The technical and logistical aspects of this concept are discussed below.

6.1 Coal Dust as a Pipeline Driver Fuel

The question of substituting coal and coal-derived fuels for the petroleum fuels presently used in pipeline operations involves consideration of the practicality of coal-fired engines and slurry-fired engines and the logistics of transporting coal and coal slurries to the pipeline pumping stations.

\subsubsection{Coal Dust as an Engine Fuel}

Any consideration of burning coal in engines presupposes that the coal has undergone certain processing. Coal receives an initial processing as it comes from the mine, including cleaning and grading to size. Those impurities that are readily removable (e.g., slate, shale, clay, sandstone, and pyritic sulfur) are eliminated by physical treatment. Organic sulfur and some incombustible materials cannot be eliminated by physical treatment. While there are techniques for removing some of the ash and sulfur, these processes are sophisticated and expensive, making it doubtful as to whether they offer any real advantage over coal liquefaction or gasification. Processing of pulverized coal for use in furnaces is a well established technology. However, little is known concerning the optimum particle size for efficient combustion in internal combustion engines.

\subsubsection{Reciprocating Engine Fuel}

Early in the development of the reciprocating internal combustion engine, attempts were made to use coal as a fuel. Almost all work has involved the use of pulverized coal either in a dry state or slurried in an oil or aqueous carrier. In 1898 Rudolph Diesel, after experimenting with an internal combustion engine using powdered coal. as fuel, developed the compression ignition engine that bears his name. The powdered coal engines were not 
then successful and were abandoned when the diesel engine, using oil as fuel, ran with an efficiency much higher than any previous eng ine.

Development projects on coal-burning diesel engines were independently conducted by five industrial companies in Germany during the period 1916. to 1944, after which all efforts in this field were terminated (Ref. 35). Under these programs, which were in progress for periods ranging from two to 24 years, approximately 19 coal dust engines in the power range from 10 to $600 \mathrm{HP}$ and rated at speeds from 160 to $1600 \mathrm{rpm}$ were built and tested. The major problems experienced can be summarized as follows:

(1) Fuel feeding and control system. The most critical components were in the pre-chamber system with its control valves and nozzles, the task of which was to hold a properly metered amount of coal dust or coal dust/air mixtures and transfer this fuel into the engine cylinder with correct timing and duration of injection in uniformly dispersed form and with a minimum of injection energy. Two basic systems were developed: (a) a compressor injection system using compressed air from an external compressor for pressurizing the pre-chamber and injecting the fuel in the cylinder; and (b) a compressor-less injection system using pressure rise through partial combustion of the fuel within the pre-chamber to inject the fuel into the cylinder. The compressor injection system had several drawbacks including high energy consumption, high cost, and complexity, will resultant reduction in system reliability. The compressor-less self-injection system did not adequately control ignition timing or injection timing or fuel leakage from the pre-chamber to the engine cylinder during the charging period. 
(2) Fuel and combustion characteristics. The widely varying chemical and physical properties of coal made it very difficult to match the operational requirements of the engine. Factors of particular importance are heating value (typically ranging from 7000 to $15,000 \mathrm{Btu} / \mathrm{lb}$ ); ignition temperature (ranging from $250^{\circ} \mathrm{C}$ for lignite to $800^{\circ} \mathrm{C}$ for anthracite) and ash content. The combustion phenomena involve three major parameters including ignition time, main combustion time, and burnout time. These parameters are affected by physical, fluid mechanical properties, and particle size and structure. Despite more than 100 years of combustion research, engineers are not yet in agreement on the exact combustion mechanism of a complex fuel such as coal.

(3) Wear and erosion. Excessive wear of vital engine components due to the abrasive action of ashes and unburned coke particles were the most serious detriment to long duration operation. Major engine components affected were cylinder liners, piston rings, injection nozzles, valve seats, and bearings and other sliding surfaces.

Although the German programs were, to a degree, successful in solving some of the basic problems of the coal-dust diesel engine, fuel consumption and efficiency, reliability and duty life of essential components were definitely inferior to those of cumparable o1l diesel engines. It is significant that virtually all engines built under these programs were experimental engines, only two of them having been put into practical use for driving machinery in factories on a routine basis.

Experience with coal-burning engines in the U.S. has been very limited, but in general has corroborated the results on those developed in Germany. Another problem of some significance, although not discussed in the German reports, is air pollution which can arise from the high sulfur content of some coals and the particulate matter in the exhaust. Because of 
these problems, as well as the wide variability of chemical properties of coal mined throughout the country, most researchers have concluded that direct utilization of pulverized coal in piston engines, at least those used in automotive and other mobile applications, is not practical. The use of powdered coal in large stationary engines should present less difficulty than in the case of the automotive engine because the stationary engines run at slower speeds and their combustion systems are less sensitive to fuel quality; however, they would still face many of the same problems with respect to metering, wear, and exhaust quality.

A relatively simple and more practical approach to burning coal in a reciprocating engine is to fit the engine with a suitable gas producer to partially convert the coal to combustible gases so that the gases may be consumed in the engine. Such gas producers convert carbon to carbon monoxide, losing about half the fuel heating value in the process. Cooled, filtered gas is then burned in the engine at normal engine efficiency, although the overall efficiency from fuel to output shaft power is of course reduced about 50\%. The only engine modification required for a spark ignition engine is to replace the carburetor with a gas-mixing valve. For a compression ignition engine, a small pilot charge of diesel fuel is required to ignite the gas. In Europe, during World War II, about 500,000 trucks and autos were operated with coal or charcoal-fired gas producers because of the shortage of gasoline. Although bulky and inefficient, these vehicles proved to be fairly reliable and demonstrated that coal (or charcoal derived from wood) could be used as an emergency fuel when conventional liquid fuels were not available.

\subsubsection{Gas Turbine Fuel}

Some of the problems involved in burning pulverized coal in piston engines are also common to the open cycle gas turbine. In particular, the turbine is susceptible 
to hot corrosion and erosion resulting from high sulfur and ash content of most coals. The gas turbine does have one significant advantage over the diesel or Otto cycle engine in that it can burn a wide range of fuels of varying ignition quality. The absence of rubbing internal parts (pistons reciprocating in cylinders) in the compression and expansion processes is also an advantage from the wear standpoint.

Modifications necesary to a gas turbine to burn solid coal efficiently have recently been investigated by Solàr Division of International Harvester Co. The work was done under a subcontract with Combustion Power Co., which had a contract with ERDA (nOw DOE) to identify the hot corrosion and erosion problems that would be expected in the hot end of a gas turbine burning coal in a fluidized bed combustor. The process included a fluidized bed combustor which operated on Illinois No. 6 coal, and three stages of filtration to remove the sulfur and separate the ash from the hot exhaust gases before they enter the turbine. The investigation indicated fouling, which can be expected from the fly ash at temperatures above about $470^{\circ} \mathrm{C}$, to be the principal deterrent to the use of coal-fired gas turbines, although erosion may become significant in the lower temperature turbine stages and during spall of deposited ash. It was concluded that future work to improve the potential of operating gas turbines on coal must identify the principal contributor to the fouling mechanism, i.e., temperature, surface chemistry, particle energy; and then investigate strategies for mitigating the ash deposits and their resultant effects on the substrate. Another contract, recently awarded by ERDA to Curtiss-wright Power systems, is aimed at demonstrating the feasibility of a gas turbine to burn high sulfur coal economically in utility service. The contract covers the design, construction, and operation of a pilot plant comprising a gas turbine with a fluidized bed combustor. This $300 \mathrm{MW}$ pilot plant will be the first step in a practical application of this principle to power generation. 
It is evident that the problems of burning coal in gas turbines are of far less magnitude than those in piston engines. If the erosion and corrosion problems can be successfully overcome, the open cycle gas turbine engine with the addition of a Rankine bottoming cycle could well prove to be a workable candidate for a prime mover for pumps used in liquid pipelines. As was discussed earlier in Section 4.1.1.2, an organic bottoming engine on a typical second generation gas turbine, representative of those presently installed on gas pipelines, could achieve an overall efficiency of more than $40 \%$ for the combined cycle plant. A retrofit of the pumping station could be accomplished either by fitting the combined cycle plant with an electric generator to supply power to the existing electric motor-driven pump, or by eliminating the electric motor and driving the pump directly from the gas turbine and Rankine cycle turbine (e.g., as illustrated in Fig. 4.1.1.2-1 above). In either case, a significant saving in operating cost over the cost of using utility power should result. There are of course other major cost factors to consider, including capital cost and maintenance cost, but the concept appears to be worthy of further study.

Another concept which merits consideration is the use of an indirect-fired coal-burning combined cycle pump station, such as a closed Brayton cycle power plant with a bottoming cycle, or some variation thereof. Since the turbine fluid (air in the case of a closed cycle gas turbine), is not subject to the corrosion and erosion problems of an open cycle plant. The problems of burning coal are therefore confined to the air heater.

Development of closed Brayton cycle systems started in 1939 and the first power plant of this type was placed in service in 1940. This was an oil burning plant manufactured by Escher-Wyss in Switzerland. The first coal burning closed Brayton system was an Escher-Wyss/GHH $2300 \mathrm{KW}$-plant which started operation in Ravensburg, Germany, in 1956. It can be regarded as the starting point for the practical use of closed cycle machines after about 20 years of laboratory testing and development by Escher-Wyss and then 
licensees. This plant had approximately 120,000 hours running time by June 1967, with reportedly only minor problems and repairs. The combustion system could be changed in only one or two days to operate on coal, oil or gas. Altogether there have been some fifteen closed cycle gas turbine plants built in Europe, Great Britain, Russia and Japan, as indicated in Figure 6.1.1.2-1. A number of these plants, including several which used coal as fuel, have accumulated over 100,000 hours of operation. Turbine inlet temperatures have ranged from 650 to $750^{\circ} \mathrm{C}$ and plant efficiencies have been in the general range of 25 to $32 \%$. Although those closed cycle plants have demonstrated economic viability, utilities have been reluctant to install them on a broad basis (Ref. 37). With the current emphasis on use of coal as fuel and with the advent in recent years of high-temperature materials, the closed Brayton cycle power plant may be the preferred approach to direct use of coal. One promising approach for achieving higher closed-turbine efficiency would be the use of new high-temperature ceramics, such as silicon nitride or silicon carbide, in the air heater. The addition of a Rankine bottoming system using waste heat from the air heater would result in a further increase in overall plant efficiency. Preliminary analysis indicates that, with a turbine inlet temperature of $1000^{\circ} \mathrm{C}$ (which should be feasible with ceramic materials in the air heater) and an organic bottoming system, an overall efficiency of over $40 \%$ could be achieved in a plant of $2000 \mathrm{KW}$ or larger. Another advantage of ceramic materials would be increased resistance to erosion and corrosion effects from combustion or pulverized coal. 


\begin{tabular}{|c|c|c|c|c|c|c|c|c|c|c|c|}
\hline Inits & Menufacturer & Application & $\begin{array}{c}\text { Continuo:1 } \\
\text { Output }\end{array}$ & $\begin{array}{c}\text { leat } \\
\text { Supply } \\
\text { (MW) }\end{array}$ & $\frac{\begin{array}{c}\text { Plant } \\
\text { Efficiency }\end{array}}{\left(\frac{\sigma}{b}\right)}$ & $\begin{array}{c}\text { Conmision } \\
\text { ing Dite } \\
\end{array}$ & $\frac{\text { Rumning Tine }}{(\mathrm{hr})}$ & Fuel & $\begin{array}{l}\text { Inlet } \\
\text { enp. } \\
\text { (oc) }\end{array}$ & $\begin{array}{l}\text { Inlet } \\
\text { Pressure } \\
\text { (bar) }\end{array}$ & Romarks \\
\hline $\begin{array}{l}\text { Zurich, } \\
\text { Switzerland }\end{array}$ & Es=her-Wyss & Polier & 2 & - & 32.6 & 1940 & 6,000 & 0.1 & 700 & - & $\begin{array}{l}\text { lst test plant } \\
\text { ret_red }\end{array}$ \\
\hline $\begin{array}{l}\text { Ravensburg, } \\
\text { Germany }\end{array}$ & $\mathrm{E} \cdots \mathrm{A}+\mathrm{CH} H$ & Power + nent & 2.3 & $2.3-4.1$ & 25 & 1956 & 120,000 to6-76 & $\begin{array}{c}\text { Coal or } \\
\text { oil }\end{array}$ & 660 & 7.2 & \\
\hline $\begin{array}{l}\text { Coburg, } \\
\text { Germany }\end{array}$ & Grt & Pcwer + ieat & 6.6 & $8-15$ & 28 & $19 \overline{-}$ & 100,000 to $6-7.5$ & Coal & 680 & 7.3 & \\
\hline $\begin{array}{l}\text { Oberhausen I } \\
\text { Germany }\end{array}$ & GlㅁI & Pcwer + heat & 13.75 & $18.5-28$ & 29.5 & 1950 & 100,000 to $6-76$ & $\begin{array}{l}\text { Coal/Cake } \\
\text { oven gas }\end{array}$ & 710 & 8 & \\
\hline $\begin{array}{l}\text { Oberhausen II } \\
\text { Germany }\end{array}$ & $\mathrm{Gl+H}+\mathrm{EVO}$ & Pciver + jeat & 50 & 53 & 31.3 & 1975 & 3,000 to $5-76$ & $\begin{array}{l}\text { Coke oven } \\
\text { gas }\end{array}$ & 750 & 10.5 & $\begin{array}{l}\text { Jst use of heliun as } \\
\text { working Fluid }\end{array}$ \\
\hline $\begin{array}{l}\text { Haus } \Lambda \text { den, } \\
\text { Germany }\end{array}$ & SItrl & $\begin{array}{l}\text { Pclier + je } 3 t \\
\text { Ccrup. driye }\end{array}$ & 6.4 & 7.8 & 29.5 & تَّكَ & 100,000 tc $6-75$ & $\begin{array}{l}\text { Mine gas + } \\
\text { coal }\end{array}$ & 680 & 9.3 & \\
\hline $\begin{array}{l}\text { Gelsenkirchen, } \\
\text { Germany }\end{array}$ & $\mathrm{JHH}$ & Pcwer + .reat & 17.25 & $20-29$ & 30 & $195^{\circ}$ & 75,000 to $16-70$ & $\begin{array}{l}\text { B1.Fur.Gas } \\
+ \text { oil }\end{array}$ & 711 & 10.2 & \\
\hline $\begin{array}{l}\text { St. Denis } \\
\text { Paris, France }\end{array}$ & - & Power & 22.5 & - & - & 195 & 5,060 since' 56 & Oil & 660 & - & $\begin{array}{l}\text { 1st Jig plant/double } \\
\text { pressurized heater }\end{array}$ \\
\hline $\begin{array}{l}\text { Toyotoni, } \\
\text { Japan }\end{array}$ & $\underset{\text { E-N }}{\text { Fuji. Eles. + }}$ & Power & 2.0 & - & 26 & $195:$ & 90,000 & Nat.gas & 660 & 7.2 & \\
\hline $\begin{array}{l}\text { Nippon Kokan } \\
\text { Japan }\end{array}$ & Fuji Elec. & Power & 12 & - & 29 & $195 i$ & 85,100 to $12 / 70$ & B1.Fur.Gas & 680 & 6.7 & \\
\hline $\begin{array}{l}\text { Rothes } \\
\text { Great Britain }\end{array}$ & - & Power & 2.0 & - & - & 1950 & $21,0100$. & Coal slurry & 660 & & $\begin{array}{l}\text { Stopged due to mine } \\
\text { closure }\end{array}$ \\
\hline $\begin{array}{l}\text { Altnabreak } \\
\text { Great Britajn }\end{array}$ & - & Power & 2.2 & - & - & 1959 & $\sim 1,000$ & Peat & 660 & & "1. \\
\hline $\begin{array}{l}\text { Kashira, } \\
\text { Russia }\end{array}$ & $E-W$ & Power + neat & 12 & $9-12$ & 28 & $195:$ & -. & Brown coal & 1680 & - & Achiaved guarantec \\
\hline $\begin{array}{l}\text { Spittelau, } \\
\text { Austria }\end{array}$ & $B B C / E-W$ & Power + ileat & $30-22$ & $25-\angle 3.3$ & $31-24$ & $197 ?$ & - & Oil or gas & 720 & - & $\begin{array}{l}\text { Achiəved guarantee; } \\
\text { disrrantled }\end{array}$ \\
\hline $\begin{array}{l}\text { Die Oxygen } \\
\text { Phoenix }\end{array}$ & $E-W+$ LaFleur & $\begin{array}{l}\text { Cryogeni: gas } \\
\text { proluction? }\end{array}$ & 2 & - & - & $1955^{\circ}$ & 5,000 & Nat.gas & 680 & - & $\begin{array}{l}\text { Helisun fluid; ċis- } \\
\text { mantled }\end{array}$ \\
\hline $\begin{array}{l}\text { Adv. Power Conv. } \\
\text { Exp. Test Facil's. } \\
\text { Ft. Belvair,va }\end{array}$ & $\begin{array}{l}\text { Corps of Fnzrs. } \\
\text { (Stratos } ə t \text { al.) }\end{array}$ & $\begin{array}{l}\text { Arriy power } \\
\text { reants. }\end{array}$ & 0.5 & - & 18.6 & $195^{\circ}$ & - & Oil & 650 & 8.1 & $\begin{array}{l}\text { Experimental } \\
\text { (fluid, } \mathrm{N}_{2} \text { ) }\end{array}$ \\
\hline $\begin{array}{l}\text { Adv, Power Conv. } \\
\text { Skid Experiment } \\
\text { San Ramon,CA }\end{array}$ & $"$ & $"$ & 0.500 & - & 16.7 & 1967 & - & Oil & 650 & 8.0 & $"$ \\
\hline
\end{tabular}

Fig. 6.1.1.2-1 - All previously instalied closed-cycle indistrial/utility power plants 


\subsubsection{Logistics of Coal Consumption in Pipelines}

The pumping stations in long distance liquid pipelines are for the most part located in remote sites, and there is currently no economical means of transporting coal to these sites. Since shipment by rail directly to the pumping station would be out of the question in most cases, the alternative would be to haul the coal by truck from the nearest rail terminal to the pumping site, where it would have to be processed into pulverized coal. This would be prohibitively expensive.

6.2 Logistics of Methanol-Coal Slurry as Pipeline Fuel

A potential solution to the logistical obstacle to use of coal in pipeline drivers lies in the use of the coal-methanol slurry, discussed earlier in Section 5.0 , where it was concluded that the methanol-coal slurry offers an extremely interesting concept for pipelining coal. When that technology is developed, it will then be practical to consider use of crude oil and products pipelines to transport slurry as well. Thus, pipelines which transport oils from oil fields and/or refineries to or through coal mining regions could also be used to move coal to their own pumping stations. The compatibility of the methanolcoal slurry with these other liquids at the interfaces must of course be investigated.

The pumping requirements of methanol-coal slurry would differ from those of crudes and products and would have to be carefully analyzed. The rheological tests described in paragraph 5.2.1 show that, with high concentratraticns of coal in the methanol-coal slurry, the pipe wall friction would be high and therefore more power would be required for a given throughput 
than with the conventional liquids. The pumps in crude oil and products pipelines are predominantiy of the centrifugal type. Although these pumps would be suitable for pumping slurry, they are not likely to be the preferred choice, so that some efficiency penalty would be suffered. The mainline pumps used on the existing coal-water slurry lines are high efficiency, piston-type pumps; as indicated in section.6.2. Although centrifugal pumps are used for in-plant commercial slurry systems, they are low efficiency type (on the order of 65\%) with a relatively wide throat impeller clearance.

Additional questions of significance revolve primarily around whether the direct combustion of methanol-coal slurry in the gas turbine prime mover is determined to be practical. As indicated earlier, there is little question tnat metnanol by itself is an excellent fuel for turbines. If it were necessary to separate the methanol from the coal, additional facilities would have to be provided and the logistics would be more complicated.

A retailed logistical analysis is beyond the scope of the present study. However, the concept appears to possess mer1t, and further study is recommended. 


\subsection{FLOW INDUCER IMPROVEMENTS}

\subsection{Liquid puimps}

Pumps used in liquid pipelines fall generally into two categories: centrifugal and positive displacement pumps. 7.1 .1 Centrifugal Pumps

Centrifugal pumps operate at relatively high speeds and are usually direct connected to the drivers, the majority of which are electric motors. Centrifugal pumps are typically described as velocity machines in that their performance depends on the rotating velocity of impeller tips. The operating parameters that vary with speed are output flow, head, and the required drive power. Flow rates vary directly with speed; head varies with the square of speed; and required drive power varies with the cube of speed. In contrast to positive displacement pumps, centrifugal pumps develop a limited head at constant speed over an operating range from zero to rated capacity; therefore, excessively high pressures cannot occur. Figure 7.1.1-1 shows typical characteristic curves for a centrifugal pump at constant rpm.

The efficiency of single stage centrifugal pumps depends on specific speed (hydraulic design), capacity, inlet head, internal running clearances, surface roughness, and stuffing box friction. The influence of specific speed and capacity are dominating in most cases. The best possible efficiencies of centrifugal pumps depend to a large extent on specific speed as shown in Fig. 7.1.1-2. At very low speeds, friction losses become excessive, resulting in a rapid drop in efficiency as specific speeds fall below $1500 \mathrm{gpm}$.

Figure 7.1.1-3 shows a family of efficiency curves for a typical centrifugal pump which would be used on a small 


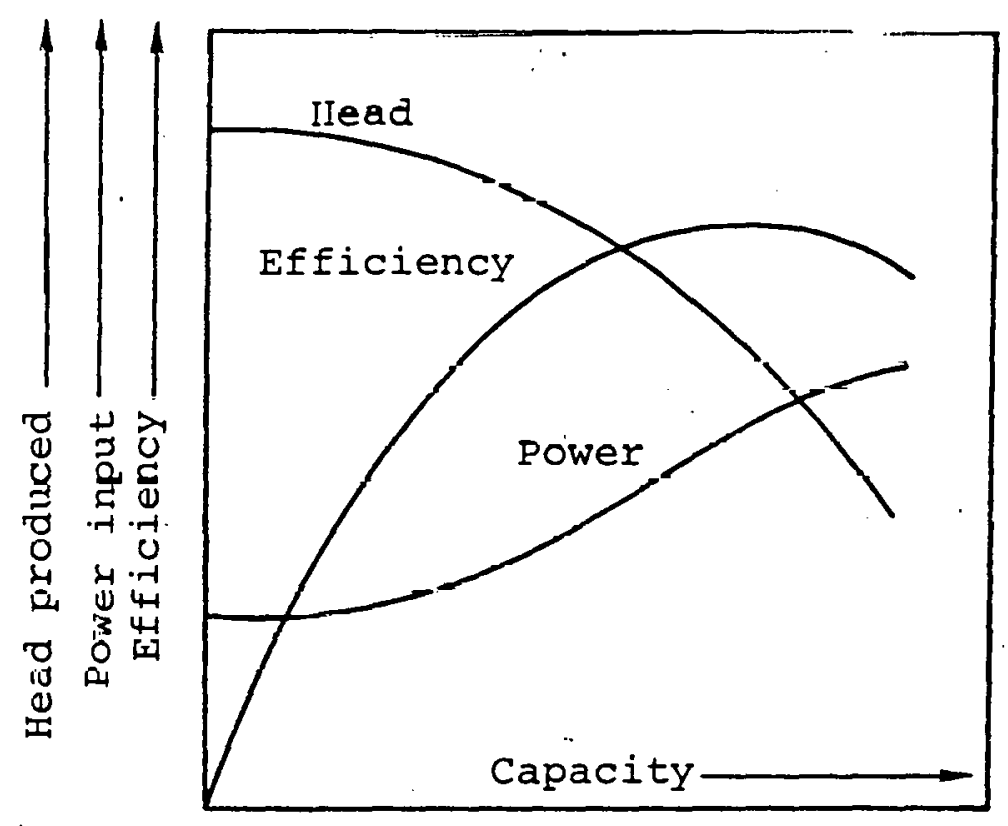

Fig. 7.1.1-1 - Typical characteristic curves at constant rpm

Source: Referrence 30 


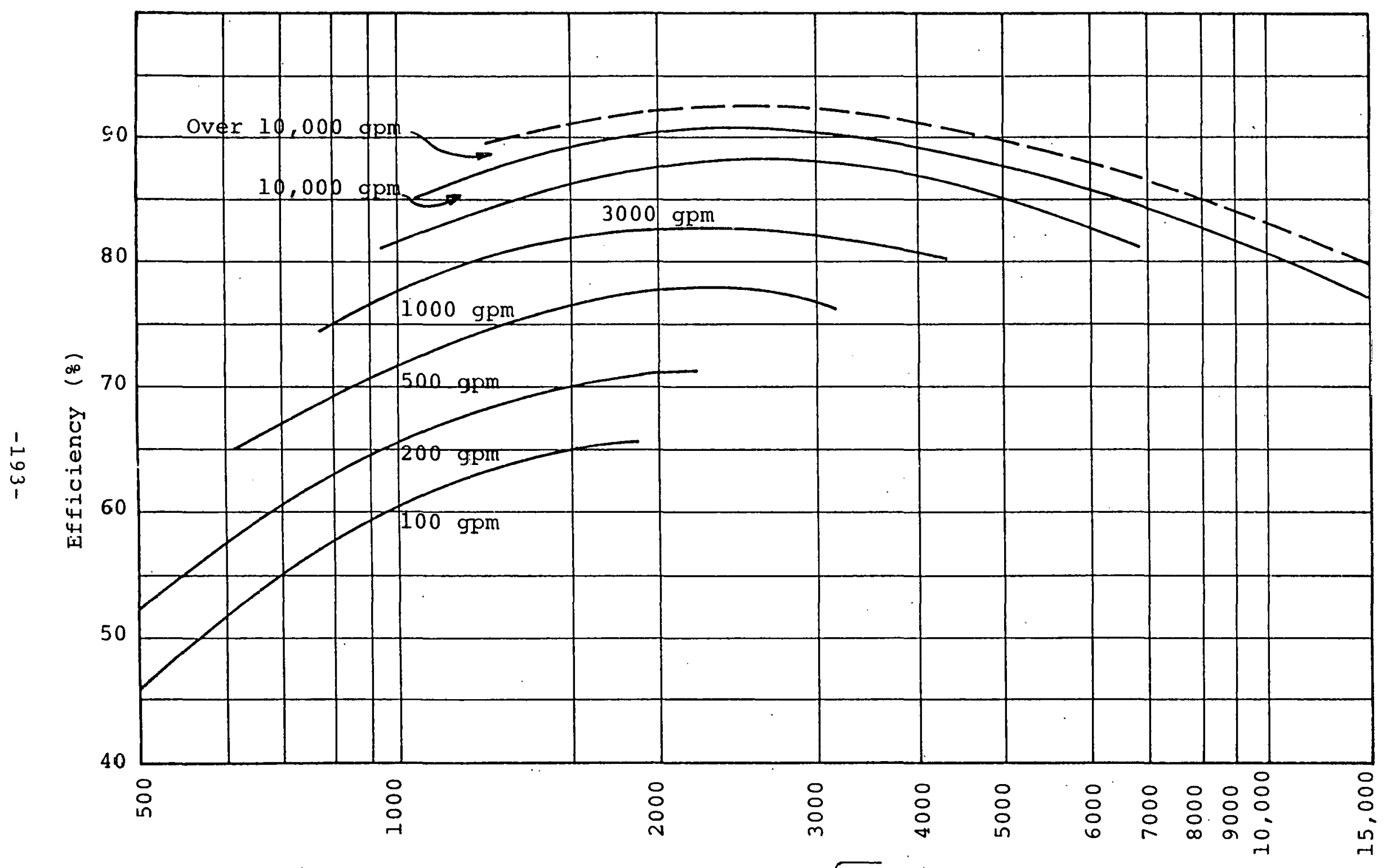

Values of specific speed, $\mathrm{N}_{\mathrm{S}}=\frac{\mathrm{rpm} \sqrt{\mathrm{gpm}}}{\mathrm{H} / 4}$

Fig. 7.1.1-2 - Efficiencies of single-stage pumps

Source: Reference 30 


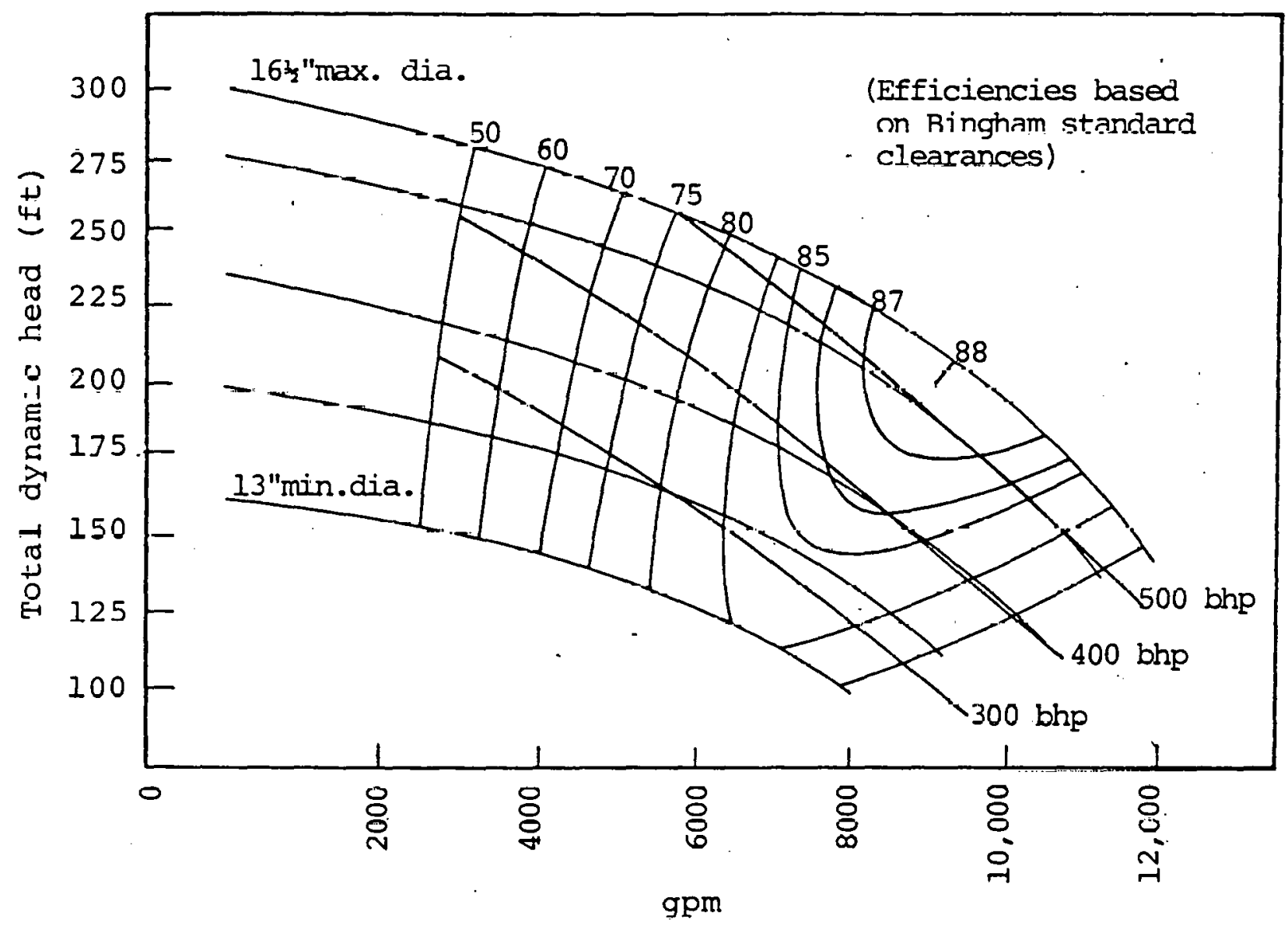

Fig. 7.1.1-3 - Efficiency curves for small commercial pipeline pump

Source: Reference 38 
products pipeline. The optimum efficiency of $87-88 \%$ is representative of current state of the art.

Centrifugal pumps used on pipelines transporting only one type of product are normally selected to provide a certain head at a design flow rate. The speed of the pump is constant for that flow rate. When the pumps are driven by constant speed motors, the throughput can be decreased by throttling. The simplest and most flexible method of varying flow is by use of a throttling valve in the output line. The throttling valve has several advantages. No pump modifications are required, and circuit changes are minor. With such a valve, flow can be varied precisely during operation to obtain required flow rates. However, throttling has several drawbacks, the most important of which is loss of pump efficiency. Because the pump is delivering full effort against a partial obstruction, total pump efficiency is low for the usable flow delivered and the driving motor may be overloaded. Accordingly, throttling is generally used only for applications requiring frequent flow variations, in which high power consumption is acceptable. Another way to achieve a lower throughput is to reduce the speed of the pump by using a variable speed drive unit, such as a diesel engine, fluid coupling, gear reduction, or variable speed motor.

When two pumps are operated in parallel, the combined delivery for a given head is equal to the sum of the deliveries at that head, as illustrated in Fig. 7.1.1-4. For satisfactory operation in parallel, the pump units must be working on that portion of the curve that drops off with increase in the individual capacities of the two units in order to assure stable flow distribution between the pumps.

When two pumps are operated in series, the combined head for any flow is equal to the sum of the individual heads at a given capacity, as shown in Fig. 7.1.1-5. 


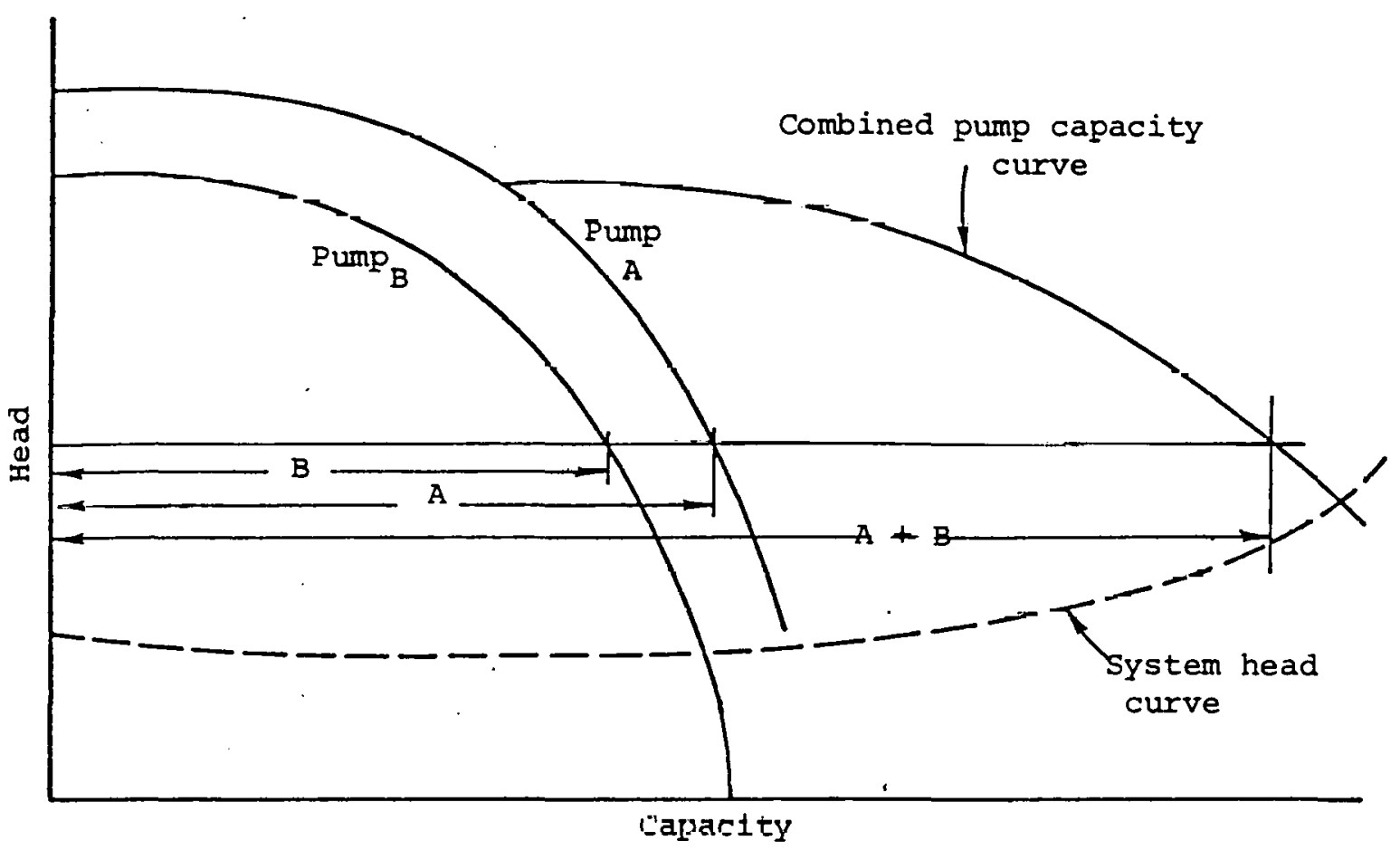

Fig. 7.1.1-4 - Head-capacity curves of pumps operating in parallcl

Source: Reference 39 


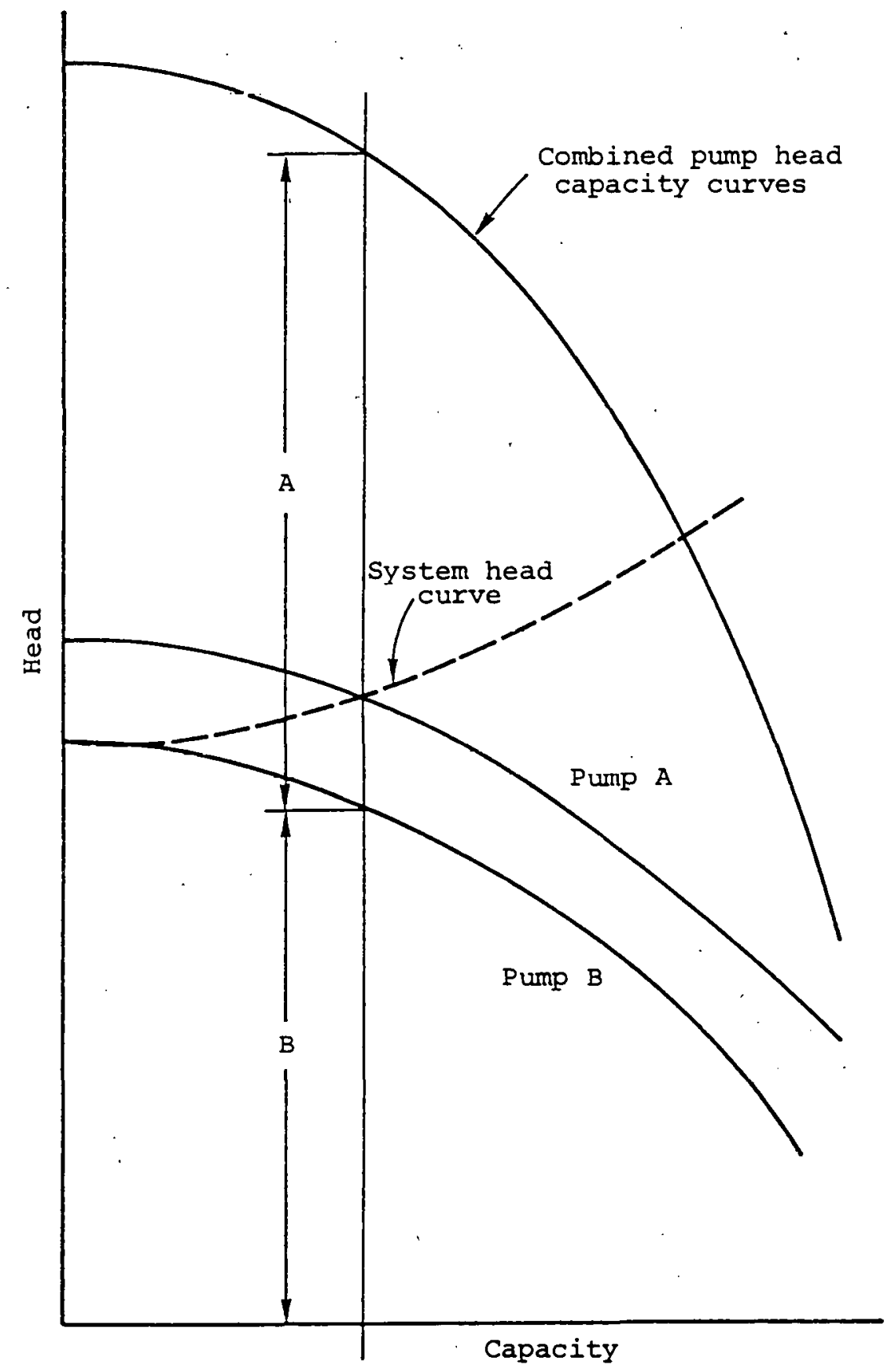

Fig. 7.1.1-5 - Head-capacity curves of pumps operating in series

Source: Refcrence 39 
Figure 7.1.1-6 illustrates an example, using two pumps in series, in which it is necessary to operate the pipeline at a throughout lower than design. Uperation at point a on lhe syslem curve requires a lower throughout, which can be achieved either by throttling by an amount represented by $\Delta \mathrm{H}$ or by operating at reduced speed along the lower of the two curves. The variable speed method of reducing throughout would normally be the more efficient method. The application of these principles to pipeline operation has been discussed in Section 4.3.6.

7.1 .2 Positive Displacement Pumps

Positive displacement pumps can be categorized into two principal classes: rotary pumps and reciprocating pumps.

A rotary pump coneiets of an assembly of jears, valves, cams, screws, vanes or other moving parts which rotate in a fixed casing. Instead of "throwinq" the liquid as in a centrifugal pump,. the rotor components push the liquid toward the discharge port much as a piston of a reciprocating pump does. Unlike the reciprocating pump, the rotary pump discharges a smooth flow. They will handle almost any liquid that is free of hard and abrasive solid material. Neglecting slip, rotary pumps deliver almost constant capacicy against variable discharge pressure. Typical capacity and horsepower characteristics of a rotary pump at a given viscosity are illustrated in Fig. 7.1.2-1.

Rotary pumps are manufactured with capacities ranging from less than $1 \mathrm{gpm}$ to more than $5000 \mathrm{gpm}$. They can handle pressures ranging to more than 10,000 psi and viscosities ranging from less than 1 centistoke to more than one million sSU. Their broadest field of application is in handing fluids that have some lubricating value and sufficient viscosity to prevent excessive slip at required pressure.

Reciprocating pumps are positive displacement units that discharge a fixed quantity of liquid during piston or plunger movement through the length of the stroke. Disregarding leaks and bypass arrangements, the volume of liquid displaced during one stroke of the piston or plunger equals the product of the piston area and stroke length. 


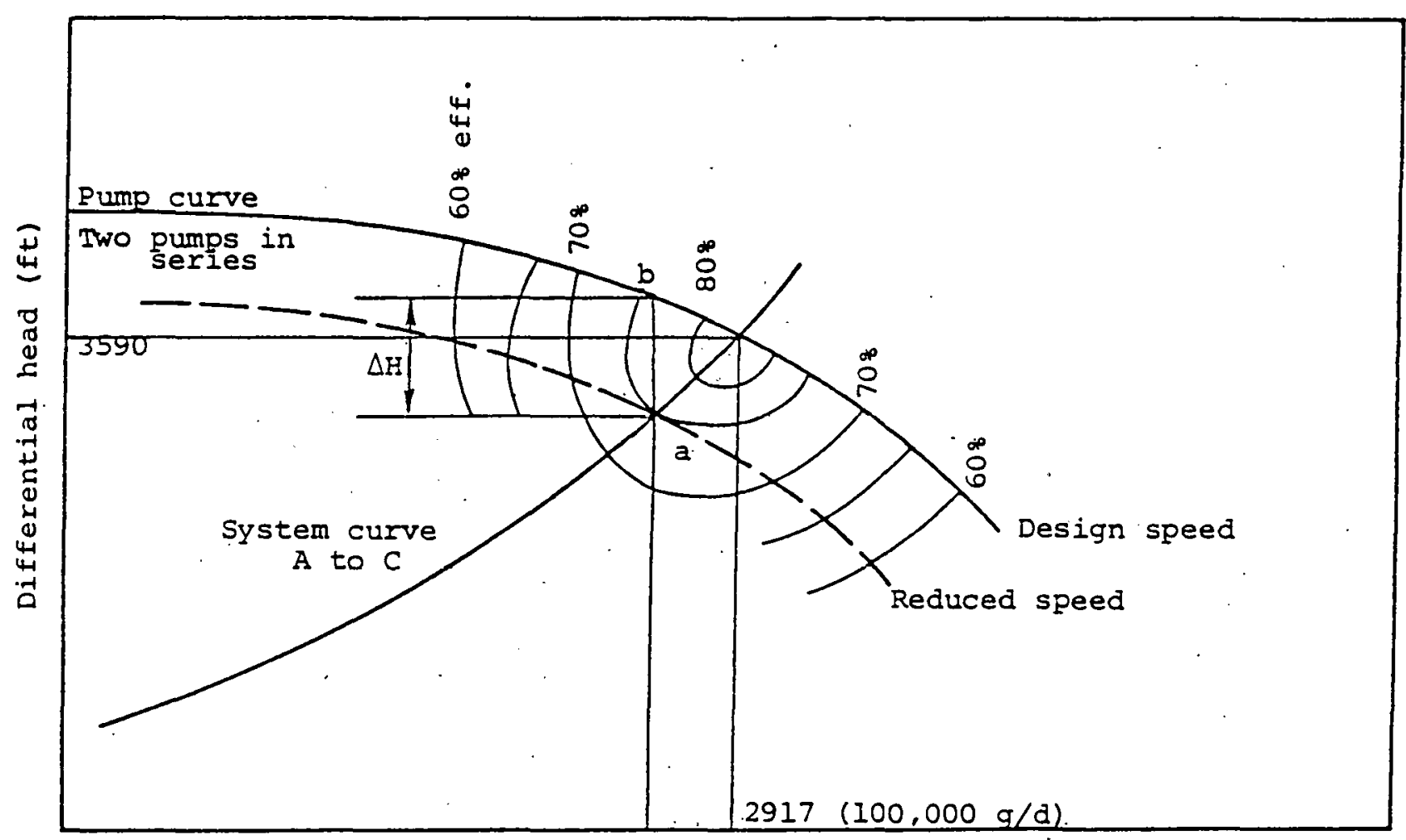

Flow rate (gpm)

Fig. $7.1 .1-6$ - Head-capacity curves at design speed and reduced speed - two pumps in series

Source: Reference 40 


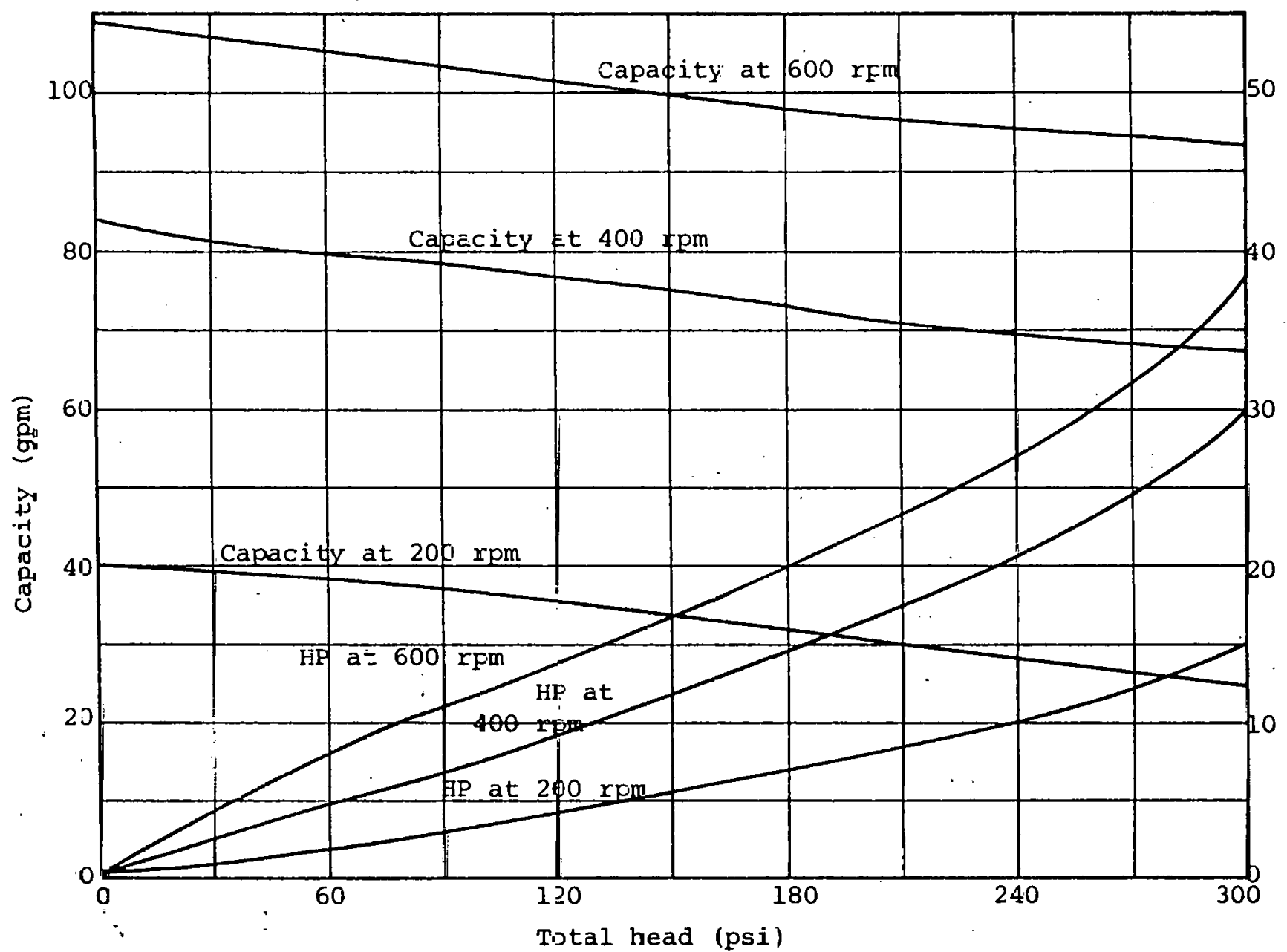

Fig. 7.1.2-1 - Capacity and horsepower characteristics of a typical rotary pump

Source: Reference 39 
The advantages of reciprocating pumps are flexibility of operation, nearly constant efficiency for wide ranges in capacity and head, and ability to handle small volumes at high heads. Disadvantages include valve.troubles, pulsating flow and head, higher cost, greater required floor space, and higher maintenance cost due to the complexity of moving parts.

Positive displacement pumps used in pipelines are predominantly of the reciprocating type. The inherently high efficiency of these pumps is almost independent of pressure and capacity and is. only slightly lower for a small pump than for a large pump. They are most useful in applications requiring high pressure and relatively low capacity, where their high efficiency more than offsets the high initial cost.

\subsection{Slurry Pumps}

One of the most demanding applications for a pump is in slurry pipelines. Both of the major coal slurry lines currently in existence use reciprocating pumps. Pertinent data on these installations are shown in Table 7.2-1 (Ref. 41).

Selection of pumps for slurry pipelines has been related primarily to two factors: required discharge pressure and abrasivity. For required discharge pressures under 650 psi, centrifugal pumps have been selected (for slurries other than coal) based on lower cost. For higher discharge pressures, only positive displacement pumps are technically feasible due to casing pressure limitations on centrifugal pumps. In systems where positive displacement pumps are utilized, the more abrasive slurries require the use of a plunger pump which has the capability to continuously flush the plunger of abrasive.material. The less abrasive materials allow the use of a piston pump. The fluid end sections of piston pumps and plunger pumps are shown in Figs. 7.2-1 and 7.2-2, respectively. In the case of the Consolidation Coal and Black Mesa slurry systems, positive displacement pumps were selected because of their higher pressures and operating efficiencies as compared with centrifugal pumps. Piston and plunger type pumps were both investigated, and the piston pumps were chosen as they were considered to have acceptable life with the abrasiveness of the coal slurry to be pumped. 
Table 7.2-2 compares pump capabilities in existing slurry lines, including other slurry materials (limestone, copper concentrate, magnetite concentrate, and others) as well as coal.

Considerable improvement in pump maintenance costs has been experienced on existing pipeline systems. This has largely been accomplished with experimental programs over a period of years. For example, the life of rubber valve inserts was increased from only 90 hours initially to 1100 hours with improved polyurethane inserts; the use of chrome-plated liners increased the life of piston inserts from 180 to 500 hours and doubled the 1 ife of liners; and piston rod packing life was increased from 100 to 6000 hours. Maintenance life on expendable parts for low and high abrasive slurries is shown in liable 7.2-3 below.

Slurry pipelines utilizing positive displacement pumps usually have at least two variable-speed operating pumps per station in order to vary throughout and to simplify restart of the pipeline after shutdown. A number of different speed control devices, as indicated in Table 7.2-4 below, are being used on existing systems.

Fluid couplings have proved to be satisfactory in high horsepower ranges. They are rugged, reliable, and require little maintenance. Eddy current couplings have performed satistactorily in the lower horsepower ranges (less than $1000 \mathrm{llp}$ ) allu piovide more precise control than fluid couplings, particularly at lower puinp speeds. Variable speed motors have also proved satisfactory for slurry pumping service, although they are more sensltive lu variations in load than fluid and eddy current couplings. The pole changing squirrel cage motor is a variable speed device capable of operating at two speeds and operates at high efticiency. at either speed. By having several pumps in parallel with different speed ratings, combinations can be used to provide several speed capabilities. The "Synchrodrive" unit is a device which combines gear reduction and speed control elements and which can be obtained in any size required for a slurry pump. This results in a saving of space and cost, and maintenance costs should be low because of reduced complexities of the system. 


$$
\text { Table } 7.2-1
$$

Reciprocating Pumps in Use in

Major Coal Slurry Lines

\begin{tabular}{|c|c|c|}
\hline & $\begin{array}{l}\text { Consolidation } \\
\text { Coal System }\end{array}$ & $\begin{array}{c}\text { Black Mesa } \\
\text { System } \\
\end{array}$ \\
\hline Length (miles) & 108 & 273 \\
\hline Diameter (inches) & 10 & 18 \\
\hline $\begin{array}{l}\text { Annual throughout } \\
\text { (million tons/yr) }\end{array}$ & 1.3 & 4.8 \\
\hline Type of pump & $\begin{array}{l}\text { Double acting } \\
\text { duplex piston }\end{array}$ & $\begin{array}{l}\text { Double acting } \\
\text { duplex piston }\end{array}$ \\
\hline Pump Manufacturer & Wilson-Snyder & wilson-Snyder \\
\hline Pump drive (hp) & 450 & $\begin{array}{l}1500,1750 \\
1750\end{array}$ \\
\hline No. of pump stations & 3 & 4 \\
\hline Total number of pumps & 9 & $6,4,3$ \\
\hline Flow per pump (U.S. gpm) & 550 & $\begin{array}{l}2100,1400 \\
2100\end{array}$ \\
\hline $\begin{array}{l}\text { Maximum discharge pressure } \\
\text { (psi) }\end{array}$ & 1200 & $\begin{array}{l}1080,1785, \\
1165\end{array}$ \\
\hline Concentration ( $\%$ by weight) & 50 & $45-50$ \\
\hline Maximum particle size & 14 mesh & 14 mesh \\
\hline
\end{tabular}

Source: Reference 41 


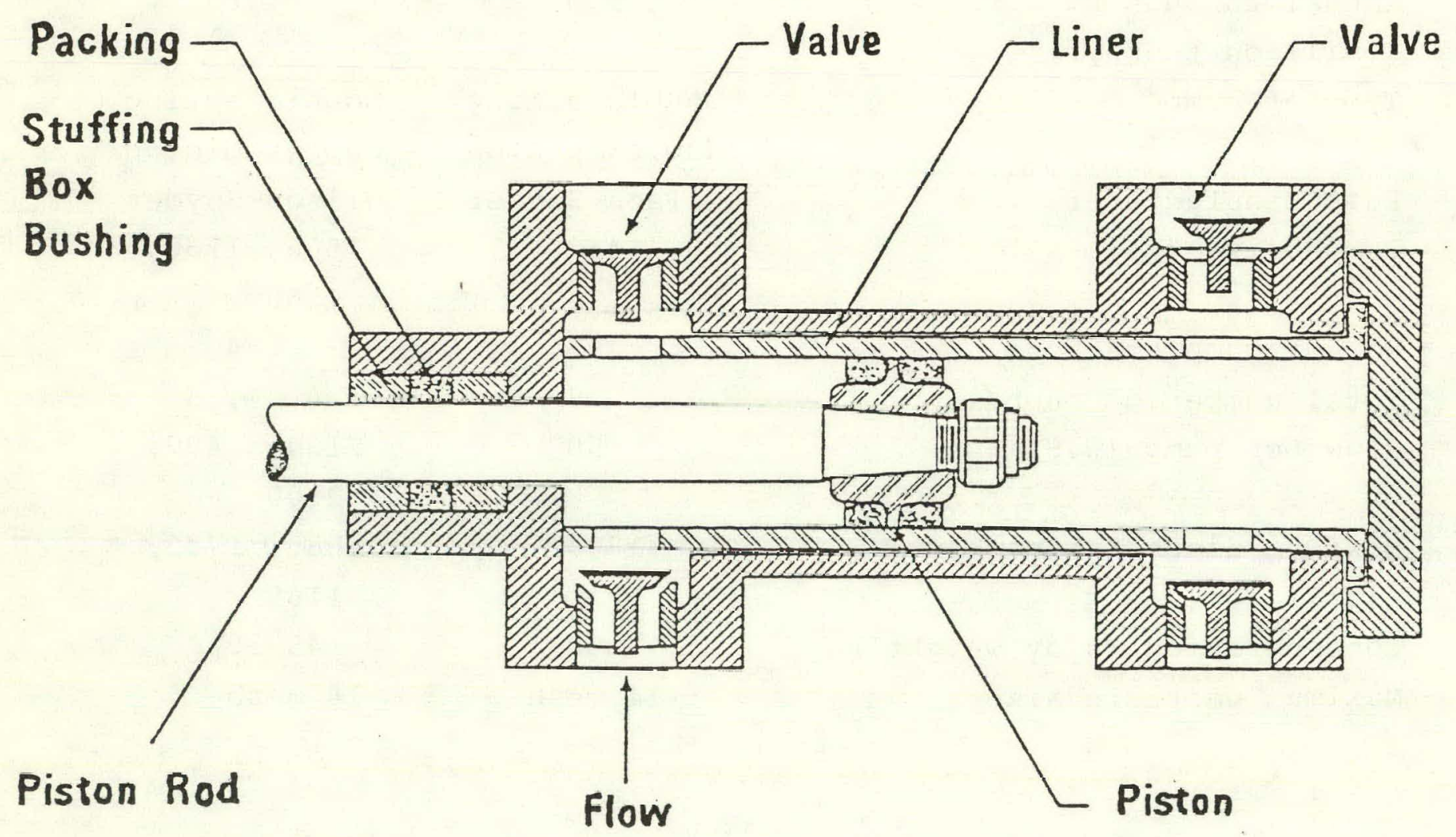

Fig. 7.2-1 - Piston pump - fluid end

Source: Reference 41 


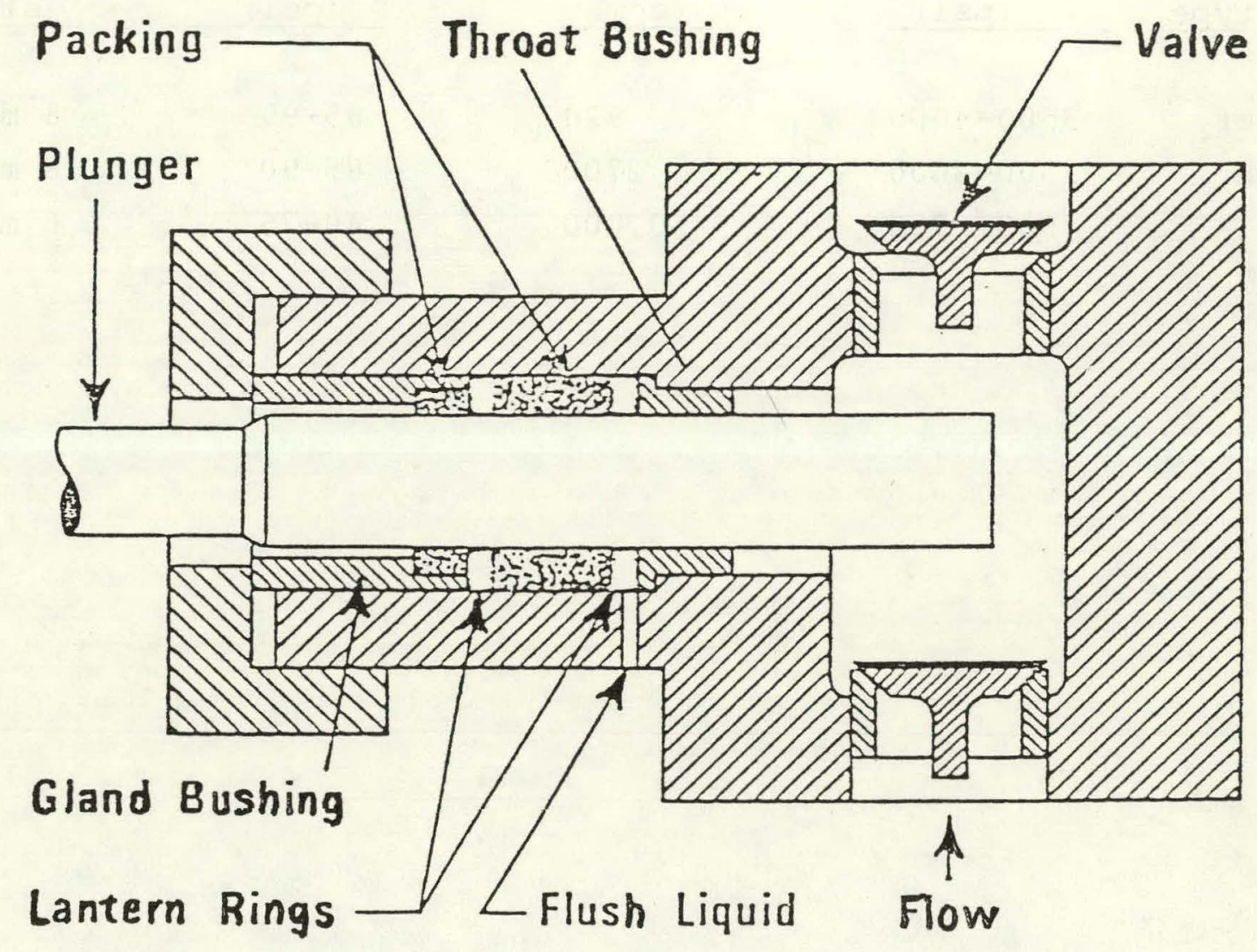

Fig. 7.2-2 - Plunger pump - fluid end

Source: Reference 41 
Table 7.2-2

Comparison of Pump Capabilities

\begin{tabular}{|c|c|c|c|c|}
\hline Fump type & $\begin{array}{c}\text { Maximum } \\
\text { pressure } \\
\text { (psi) }\end{array}$ & $\begin{array}{l}\text { Maximum } \\
\text { flow } \\
\text { (gpm) } \\
\end{array}$ & $\begin{array}{l}\text { Mechanical } \\
\text { efficiency } \\
\text { (psi) }\end{array}$ & $\begin{array}{c}\text { Maximum } \\
\text { particle } \\
\text { size } \\
\end{array}$ \\
\hline Plunger & $3500-4000$ & 920 & $85-90$ & 8 mesh \\
\hline Piston & $2500-3000$ & 2700 & $85-90$ & 8 mesh \\
\hline Centri- & $600-700$ & 50,000 & $40-75$ & 6 mesh \\
\hline
\end{tabular}

fugal

Source: Reference 41 
Table $7.2-3$

Maintenance Life on Expendable Pump Parts

Expendable Part Life

(hours)*

Low abrasivity

(piston)

Valves

Piston rod

Plunger sleeve

Piston liner

Brass bushings

Packing
1100

3000

-

4000

$-$

6000
High abrasivity

(plunger)

500

720

$-$

425

425

*Approx. 1500 psi differential pressure

Source: Reference 41 
Epced Control Devices fö Electric Drive Slurry Pumps

Type Speed Control

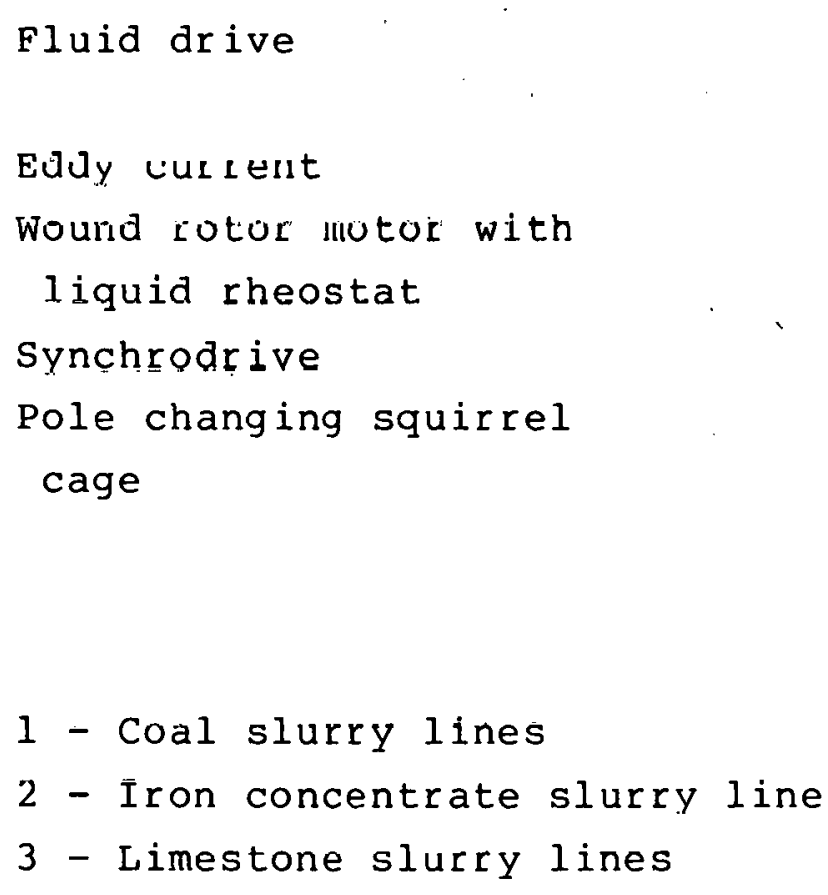

Where Used

Consnlinatinn Coal ${ }^{l}$, Savage River ${ }^{2}$, Black Mcsal Calaveras ${ }^{3}$, Waipipi ${ }^{1}$ Bougainvilite

West Irian 5

Trinidad ${ }^{3}$
4 - Maqnetite concentrate slurry line
5 - Copper coincentrate slurry line

Source: Reterence 41 
Centrifugal pumps are used extensively for in-plant cominercial slurry systems, typically those used for in-plant transportation of slurries in the mining, cement, and other industries. Their application is generally restricted to short distances because of their limited head capability, lower allowable casing pressures, and lower efficiencies. On long distance slurry pipeline systems they sometimes serve as booster pumps, providing suction pressure required for mainline reciprocating pumps. Centrifugal pumps are also used to pump slurry through safety loops, allowing system operators to monitor the slurry for quality before committing it to the pipeline.

The efficiency of a centrifugal slurry pump is low because of the necessarily robust nature of the impeller design and the relatively wide throat impeller clearance. Efficiencies of $65 \%$ are common, compared to 85 to $90 \%$ on the positive displacement pumps used in slurry systems. The centrifugal slurry pump is a flexible piece of equipment in that, if sufficient drive horsepower has been installed, the head capacity can be increased or decreased simply by changing the speed of the pump. Beltdriven units are most common and the speed change is generally achieved by changing the drive sheave. In pumps with metal impellors, the diameter of the impeller can be increased or decreased to match the system characteristics.

New coal slurry pipelines in the planning stages may require throughputs as high as 20,000 U.S. gallons per minute to be transported hundreds of miles. Assuming that the pumps on the new generation slurry pipelines will be adaptations of existing positive displacement pumps, this could mean that pump capabilities of 4000 to $5000 \mathrm{gpm}$ (as compared to the $1785 \mathrm{gpm}$ maximum capacity of present pumps) will be desirable.

Another type of positive displacement pump which may offer potential for future slurry pipelines is a high flow, high pressure axial flow pump such as used in the NASA Saturn space program for pumping liquid hydrogen. A pump of this type is available with a volume flow rate of $18,000 \mathrm{gpm}$ at $1000 \mathrm{psi}$ discharge pressure. It could therefore replace as many as eight of the present piston 
pumps in a long distance coal slurry pipeline, and would probably require less maintenance. However, the axial flow pump is approximately $5 \%$ less efficient than the piston pumps now used, and it is doubtful if the overall cost would be less than with piston pumps of the latest design.

In general, it is concluded that the state of the art in both centrifugal and positive displacement pumps is well advanced and there are no technological breakthroughs which could be exploited in an DOE-supported program.

\subsection{Compressors}

Until about 1947, the compression requirements of natural gas pipelines were satisfied entirely by reciprocating compressors. Since that time, the acceptance of the centrifugal compressor has steadily increased until it constitutes a substantial proportion of the total transmision compression horsepower installed. Figure 7.3-1 (Ref. 3 and Ref. 42) shows graphically the total capacity in installed compression horsepower for both gas turbine-driven centrifugal units and reciprocating units for the years 1963 through 1973. Over 50\% of the total transmission line compression horsepower installed during this period was of the turbine centrifugal type. However, during 1973, the trend reversed. Since the Arab oil embargo, not only have new units tended toward reciprocators because of their higher efficiency, but on those lines whose sources are decreasing, the first units to be taken out of service were the turbines.

The centrifugal compressor is classified as a dynamic machine because all compression is achieved by continuous dynamic action of the blades and channels. Inertial forces are transmitted by a rotating impeller which, by centrifugal motion, adds kinetic energy to the gas acceleration. The gas flows from the impeller into the diffuser where the gas decelerates and the kinetic energy is transformed into potential energy, i.e., pressure energy. A single centrifugla stage provides a relatively low pressure ratio (current$1 y$ in the range of about 1.15 to 1.4 ). When larger ratios are desired, additional stages are added in series. 


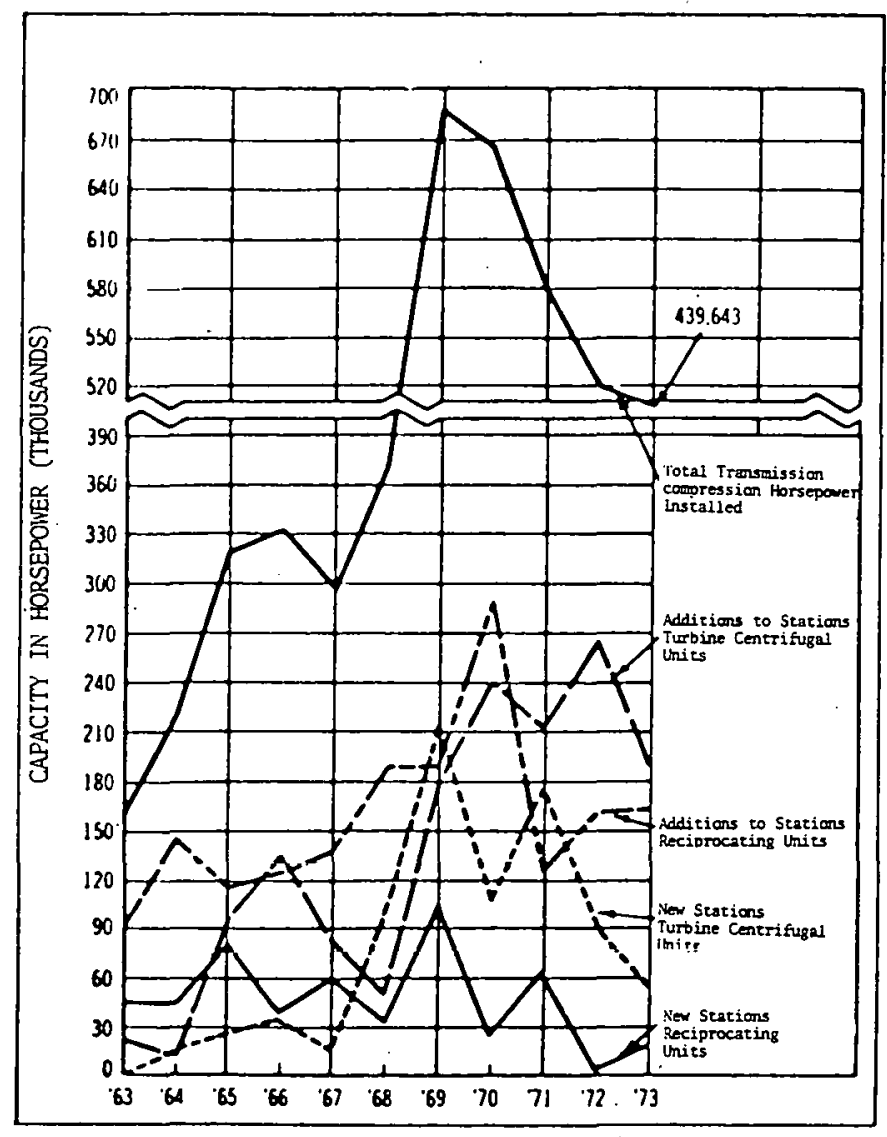

Fig. 7.3-1 - Transmission Line Compression Installed (reported 1963-1973)

Source: Reference 42 
The natural gas centrifugal compressor was originally designed for natural gas boosting service. Pressure ratios up to 5:1 or higher (depending on gas properties) over a wide range of flows can be achieved. Higher pressure ratios can be obtained by operating two or more compressors in series with intercooling. Maximum discharge pressures of up to 4000 psig can be obtained using a high-pressure case.

The centrifugal compressor has broad pressure-volume characteristics. These are accomplished by using backward swept impeller blades, vaneless diffusers, and a variety of inlet guide vanes. Compressors using this type of staging have relatively low pressure ratios per stage, so a multistage machine is necessary for all but the lowest pressure ratios.

One of the most important parameters for classifying compressor impellers hydrodynamicalily is specific speed. It is calculated by the formula

$$
\text { Specific speed }=\frac{\mathrm{rpm} \sqrt{\mathrm{Q}}}{\mathrm{H}^{3 / 1}}
$$

where

$$
\begin{aligned}
& Q=\text { inlet volume flow (ICFM), and } \\
& \mathrm{H}=\text { head (feet) }
\end{aligned}
$$

The specific speed is the speed that would be required of a geometrically sinilar machine to produce unit head with unit flow.

The peak efficiency of centrifugal impellers occurs in the specific speed range of 650 to 800 . The selection of design speed among available gas turbine drivers is limited, and the pipeline industry has been reluctant to use gears. Therefore, in some cases it may not be possible to obtain the best specific speed range with the driver speeds available. However, efficiencies of over $80 \%$ within the specific speed range of 400 to 1350 can be expected with most single-stage impeller wheels. Figure 7.3-2 shows how the maximum flow capability of a compressor changes depending on the head (Ref. 43). 


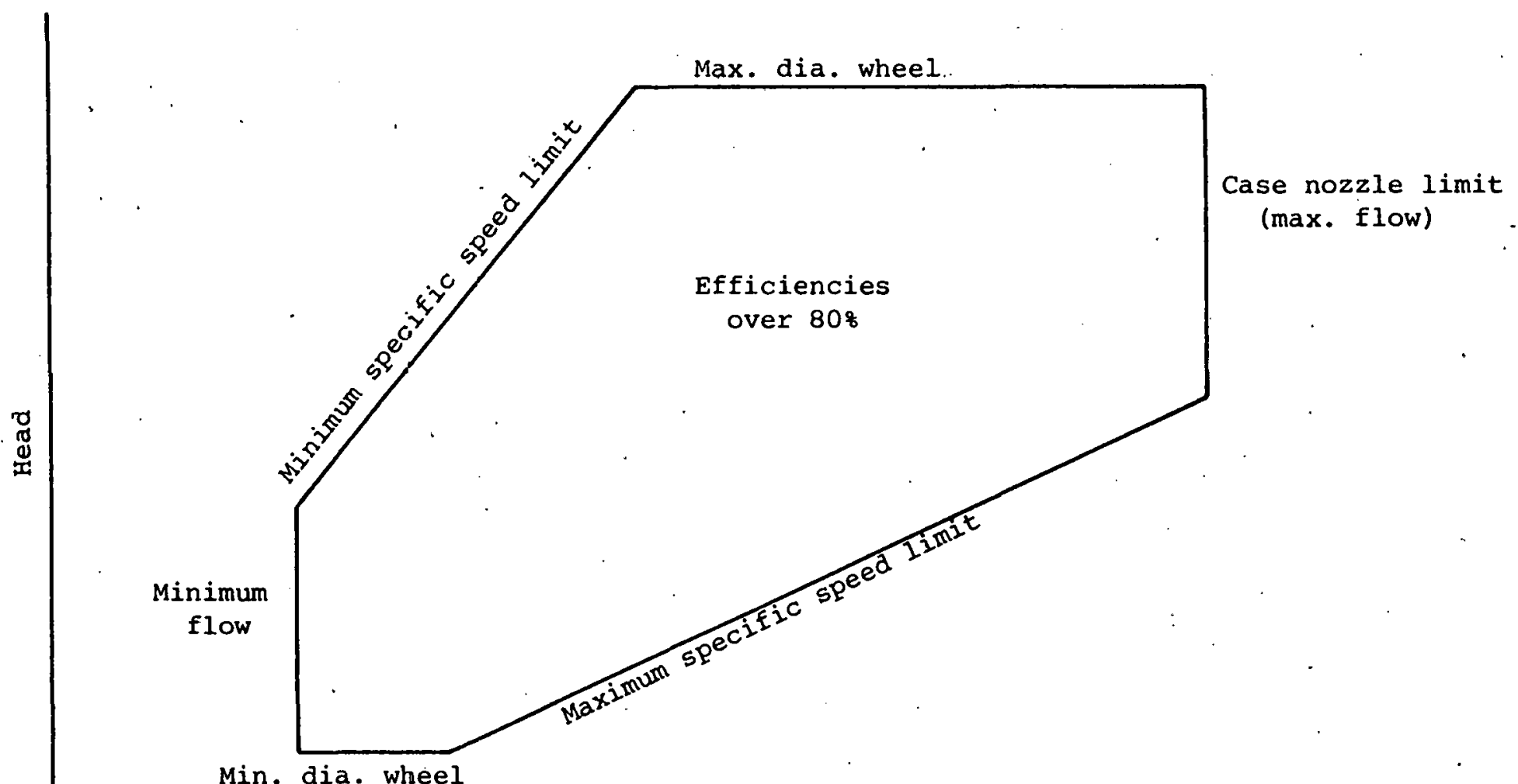

Min. dia. wheel

Inlet flow

Fig. 7.3-2 - Centrifugal compressor case characteristics 
Development of higher efficiency centrifugal compressors is continually pursued by some of the major industrial firms. For example, one of the leading gas turbine manufacturers has achieved an optimum efficiency of $86 \%$ in a single-stage compressor of 1.3 pressure ratio with a 24-inch-diameter impeller. However, the improvements in single-stage compressors cannot be directly translated into multistage machines, which require some compromises because of the broad range of flows and pressures involved.

In a typical case, a given compressor configuration is desiqned to handle a wide ranqe ot applications. For example, f'ig. 7.3-3 shows a performance map of a Solar C505 centrifugal gas compressor. Using the curves, it is possible to determine whether a specific compression job is within the capability of this basic machine, and how many stages would be required for the specific site condition.

At the low heads required for pipeline service, the axial flow compressor could offer the possibility for a 6 to $8 \%$ improvement over current centrifugal equipment. About 24 axial flow compressors have been built and operated in closed-cycle gas turbine power plants throughout the world, where the pressure levels, volume flows, and heads are comparable to gas pipeline requirements. Such a compressor, however, has two problems, one in design and the other in operation. The design problem is that of coping with the high bending loads imposed on the blading by the high specific mass tlow. The operational problem stems trom the narrower operating range from design point to surge at the tip speeds dictated by available turbine speeds and inlet volume flows (Ref. 44). The axial flow compressor is also less rugged, more complex, and more sensitive to damage from ingestion of foreign objects than a centrifugal type. With the efficiency improvements that are being made in centrifugal compressors, there appears to be little likelihood that the axial compressor will be bullt in any substantial numbers for pipeline service. 


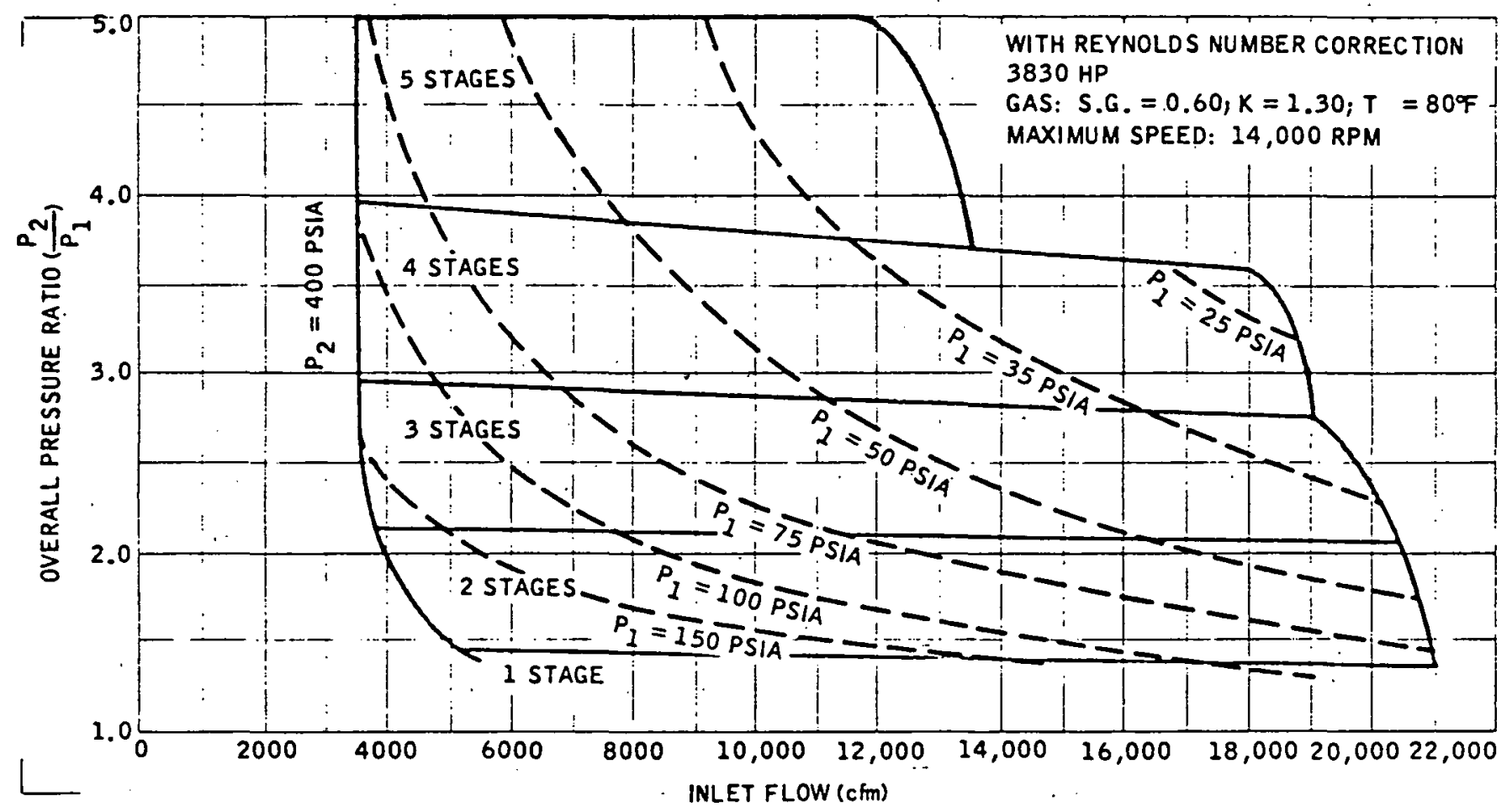

Fig. 7.3-3 - Solar C505 compressor performance

Source: Reference 1 
The reciprocating compressor is classified as a positive displacement type machine in which a quantity of gas is drawn into a cylinder, where its volume is reduced and its pressure increased by movement of a reciprocating piston. Piton compressors are designed for pressures as low as 1 psi above atmospheric or, with single stage compression, up to approximately $100 \mathrm{psi}$. When higher pressures are desired, the compression is divided into stages. The reciprocating compressor has the advantage of higher efficiency than the centrifugal compressor at the higher pressure ratios, although in many applications the centrifugal can claim efficiency superiority at pressure ratios below 1.35 as illustrated in Fig. 7. 3-4 (Ref. 43).

Many of the gas engine compressors used in pipeline applications are of the integral type, in which the power cylinders and compressor cylinders are arranged in a V-angle configuration on the same block and crankshaft. Normally such a machine has one compressor cylinder for each two power cylinders. Other gas engine compressors are furnished as matched engine-compressor sets, with the engine driving a separate compressor unit. Unloader valves used in the compressor cylinders are of various types, including both poppet and plate valves.

Many of the reciprocating engine compressors installed in natural gas transmission lines are operated in parallel with centrifugal compressors. In most cases there are several of the reciprocating engines with a large number of unloaders on the compressor cylinders. The reciprocating engine compressor units are usually of lesser capacity than the centrifugal compressor. station control is accomplished by the unloaders until the horsepower is reduced to permit shutdown of a unit. Since a centrifugal compressor limpeller has an operating flow range of approximately $/ 0$ to $130 \%$ of the design flow, it is not desirable to use a larqe centrifugal to handle the flow swings of a station when in parallel with reciprocating engines. It is much more desirable to bead load the centrifugal to a certain horsepower level and allow the reciprocating units to handle the station swings (Ref. 43). 
In general it is conclude that, as far as efficiency improvements are concerned, there does not appear to be any significant rationale for advancing the state of the art. in the compressors themselves by DOE support. Rather, as discussed elsewhere in this report, the principal gains in efficiency will come from the prime movers through new design concepts and cycle improvements.

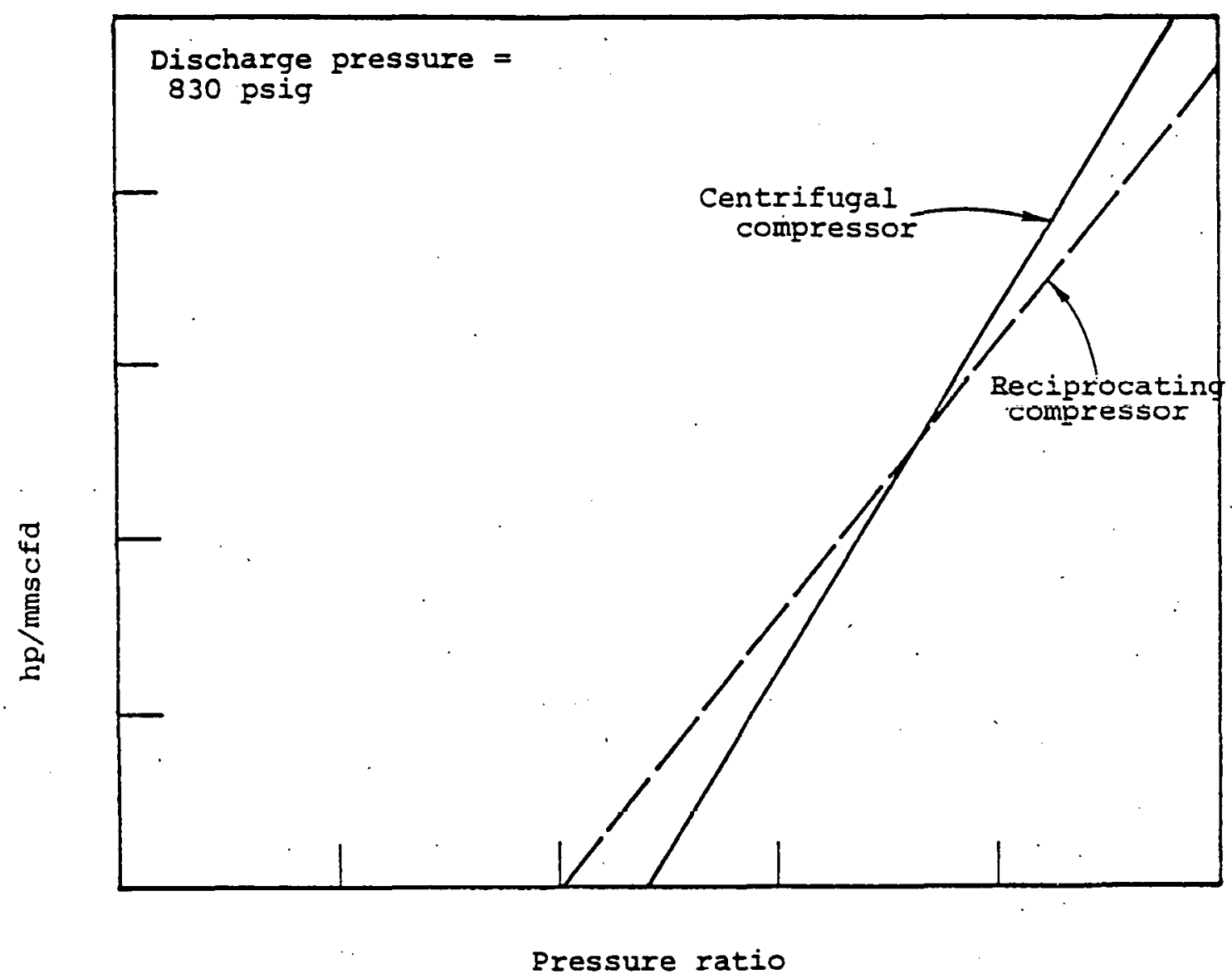

Fig. 7.3-4 - Typical horsepower requirements for centrifugal and reciprocating compressors 


\subsection{REDUCTION OF RESISTANCE TO FLUID FLOW}

To examine the potential savings in both energetics and economics that might accrue from significant reductions in resistance to fluid flow, some simulations were run using the pipeline economic model (PEM), which was developed under Task 1 of this project. The model is described in References 8 and 9.

For the simulation, the baseline petroleum products reference system, with a linefull consisting of $70 \%$ gasoline, 5\% avgas, 5\% kerosene, and $20 \%$ No. 2 fuel oil, was compared with the same system and linefill, but with viscosity reduced by factors of two and five. Sclected output results are tabulated in Table 8.0-1.

It is seen that for the 20-year period from 1976 to 1976, a saving of $\$ 22.375$ million in total energy cost could be derived from reducing the viscosity by one-half and a saving of $\$ 48.205$ million from reducing the viscosity to one-fifth that of the baseline case. Savings in present value of the energy used are $\$ 6.516 \mathrm{million}$ and $\$ 14.016 \mathrm{mill}$ ion for the one-half viscosity case and the one-fifth viscosity case, respectively. These savings figures are obtained by comparing the "Energy Costs" fand "Present Value of Energy Used" for the three viscosity categories under "theheading "Energetics" in Table 8.0-1. They are attributable entirely to the increased throughput which could be obtained by viscosity reductions alone and do not take into account any additional capital expenditures which might be involved in achieving the viscosity reductions.

The three primary methods of reducing fluid resistance in pipelines are:

(1) Heating the fluid to reduce viscosity

(2) Using additives in the fluid to reduce viscosity

(3) Using internal coatings in the pipe to reduce friction.

\subsection{Pipeline Heating to Reduce Viscosity}

The use of heating in petroleum pipelines has been confined primarily to relatively short length lines (100mi or less) carrying liquids such as heavy crudes and heavy fuels oils which are too 
Table $8 \cdot 0-1$

Viscosity Reduction study *

\begin{tabular}{|c|c|c|c|c|c|c|}
\hline \multirow{3}{*}{ Activity } & \multicolumn{2}{|c|}{ Baseline Case } & \multicolumn{2}{|c|}{ Viscosity reduced to $\frac{1}{2}$} & \multicolumn{2}{|c|}{ Viscosity reduced to $1 / 5$} \\
\hline & Total $(20 x x)$ & Average & Total & Average & Total & Average \\
\hline & & & & & & \\
\hline Throughput (MM bbl/mi) & $1,704,590.7 \subseteq 7$ & $85,229.539$ & $1,704,590.797$ & $85,229.539$ & $1,704,590.797$ & $85,229.539$ \\
\hline Revenues & $1,612,855.578$ & $80,642.775$ & $1,590,763.516$ & 79.538 .176 & $1,565,276.891$ & $78,263.844$ \\
\hline Economics & & & , & & & \\
\hline Operating income(ICC Rules) & $430,947.0 \subseteq 4$ & $21,547.354$ & $431,157.617$ & 21.557 .881 & $: 431,413.906$ & 21.570 .695 \\
\hline Net income (book profit) & $375,137.840$ & $17,863.707$ & $375,348.352$ & $17,873.731$ & $375,604.641$ & $17,885.935$ \\
\hline $\begin{array}{l}\text { Present value of book } \\
\text { profits }\end{array}$ & $136,608.590$ & $6,830.429$ & $136,787.037$ & $6,839.352$ & $137,004.424$ & $6,850.221$ \\
\hline Net cash generated & $302,389.715$ & $15,119.486$ & $302,600.223$ & $15,130.011$ & $302,856.520$ & $15,142.826$ \\
\hline $\begin{array}{l}\text { Present value of net cash } \\
\text { generated }\end{array}$ & $115,793.697$ & $5,786.185$ & $115,902.142$ & $5,795.107$ & $116,119.530$ & 5.805 .977 \\
\hline $\begin{array}{l}\text { Rate of return on total } \\
\text { capital (8) }\end{array}$ & 8.470 & 8.470 & 8.472 & 8.472 & 8.474 & 8.474 \\
\hline Energetics & & & & & & \\
\hline Energy used (MM kw-hr) & $5.577,754.250$ & $278,887.711$ & $5,022,350.187$ & $251,117.508$ & $4,381,353.437$ & $219,067.672$ \\
\hline Energy costs. (MM \$) & $225,170,787$ & $11,258,539$ & $202,796,303$ & $10,139,815$ & $176,965,961$ & $8,848,298$ \\
\hline $\begin{array}{l}\text { Presen = value of energy } \\
\text { used (e108) }\end{array}$ & $65,065.001$ & - & $58,549.497$ & - & $51,044.112$ & - \\
\hline
\end{tabular}

\footnotetext{
Dollars in thousands
} 
viscous to be pumped at ordinary ambient temperatures. Practice in the past has been to heat the liquid to a temperature mcuh above its pour point (often from $140^{\circ} \mathrm{F}$ to $210^{\circ} \mathrm{F}$ ) at the initial pumping station, then pump it through an insulated pipeline, kept hot by runnig a parallel, smaller line carrying steam. On such lines the pumping stations are usually spaced closely together and the oil is heated at each station.

Polyurethane foam coatings have been used for thermally insulating pipelines for more than 10 years, but extensive use of these coatings has occurred only since about 1970 (Ref. 45). More than $600 \mathrm{mi}$ of insulated pipeline of all sizes, incluaing length of pipeline up to $100 \mathrm{mi}$, have been installed since that time. 'lhe value of polyurethane foam for thermal insulation lies in the fact that it has the lowest value of thermal conductivity $(0.13 \mathrm{Btu} / \mathrm{sq}$./ $\mathrm{ft} / \mathrm{hr} /{ }^{\circ} \mathrm{F} / \mathrm{in}$-per ASTM D2326) of all commercial insulation materials. Another method of heating developed more recently uses a concept known as "skin effect current tracing" (SECI). This system, as illustrated in Fiqs. 8.1-1 and 8.1-2, uses the principal of skin effect, whereby. a conauctor is placed inside a heat tube and grounded to the far end of the heat tube (Ref. 46). The heat tube is welded to the exterior of the carrier pipe, which is common carbon steel pipe. An AC potential is applied between the heat tube and conductor, causing an alternating current to flow down the conductor and return on the inside of the heat tube. The depth of penetration (skin depth) of the current is related inversely to the square root of the frequency, relative magnetic permeability of the heat tube, and conductivity. of the heat tube. The welded contact between the heat tube and the carrier pipe provides a heat flow path, and the temperature of the heat tube is normally not more than 15 to 20 degress higher than that of the fluid. At the SECT control center, a transformer (Fig. 8.1-2) is provided for stepdown of the high voltage. power supply, and temperature controls are used to maintain the required temperature settings. For most applications, one heat tube is used for fluid pipes up to 12 inches in diameter, two tubes for intermediate sizes and three or more tubes on pipes larger than 30 inches in diameter. 


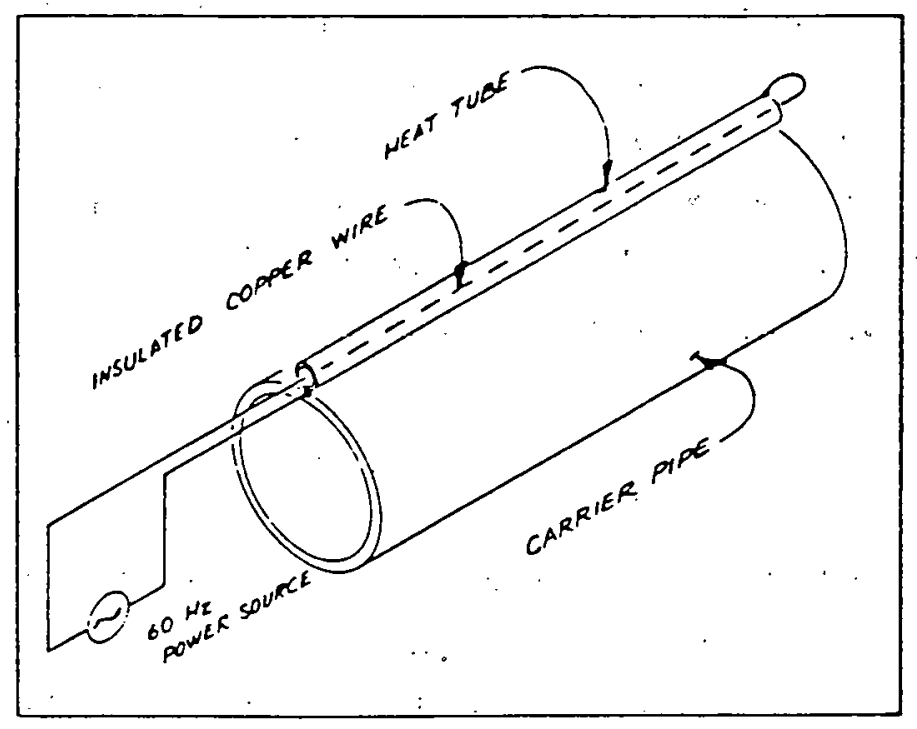

Figure 8.1-1 Basic skin effect tracing circuit.

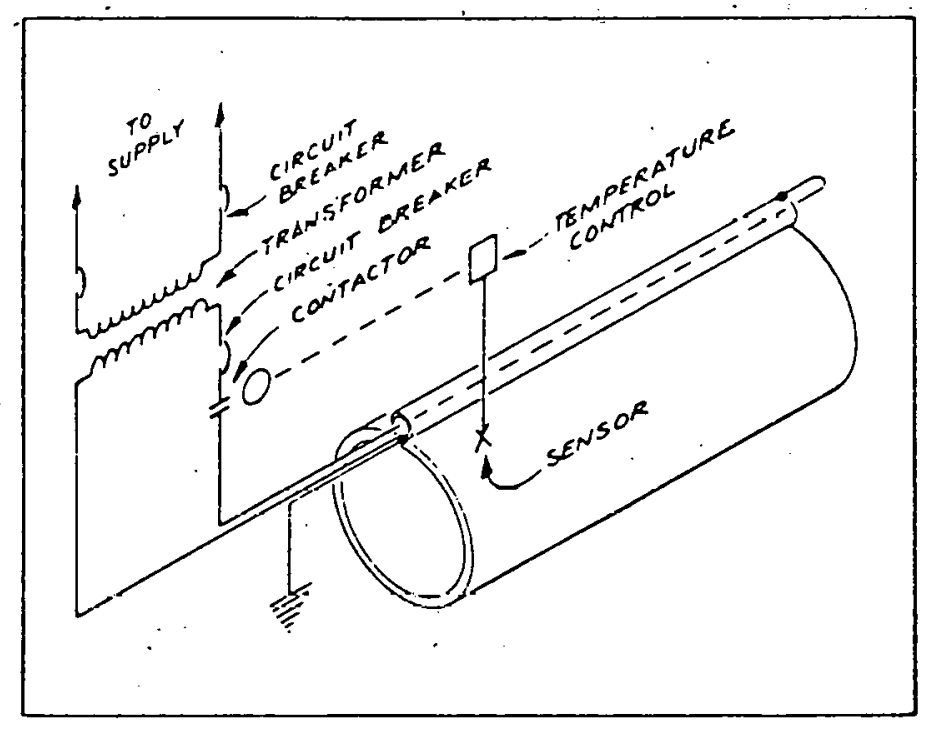

Figure 8.1-2 Details of SECT power circuit.

Source: Reference 46

$-221-$ 
The SECT system was developed in Japan and is licensed to the Ric-Wil Co. of Canada and its subsidiary, Pipe Heating systems, Inc., of Brecksville, Ohio. It has been used for heating pipelines carrying viscous crude, heavy fuel oil, molten sulphur, chemicals, etc. Approximately 45 systems have been installed in the United States in lines ranging up to about $10 \mathrm{mi}$ long.

The effect of temperature on liquid viscosity may be correlated within the accuracy of most experimental data ( 1 to 2\%) with the de Guzman-Andrade equation (Ref. 47).

$$
\mu=\mathrm{Ae}^{\mathrm{B} / \mathrm{T}}
$$

This requires knowledge of two or more values of for evaluation of the constants $A$ and $B$. When only one value of is known, the temperature dependence may be obtained within approximately $20 \%$ with the generalized chart shown in Fig. 8.1-3 (Ref: 47). The chart is based mainly on data for organic liquids and is representative of 1 iquids such as crude oil and petroleum products. IE 15 evident that heav liquids experience a much greater change in viscosity with changes in temperature than lighter Iiquids. This can be illustrated by the following example, which compares the viscosities of two typical cruāe oils at two different temperatures (Ref. 30)

\begin{tabular}{|c|c|c|c|}
\hline & & $\begin{array}{c}\text { Temperature } \\
(\mathrm{OF}) \\
\end{array}$ & $\begin{array}{r}\text { Viscosity } \\
\text { (Centipoises) } \\
\end{array}$ \\
\hline \multirow[t]{2}{*}{ California } & crude, light & 60 & 48 \\
\hline & & 150 & 9 \\
\hline \multirow[t]{2}{*}{ California } & crude, heavy & 60 & 3500 \\
\hline & & 150 & 70 \\
\hline
\end{tabular}

Source: Reference 30 


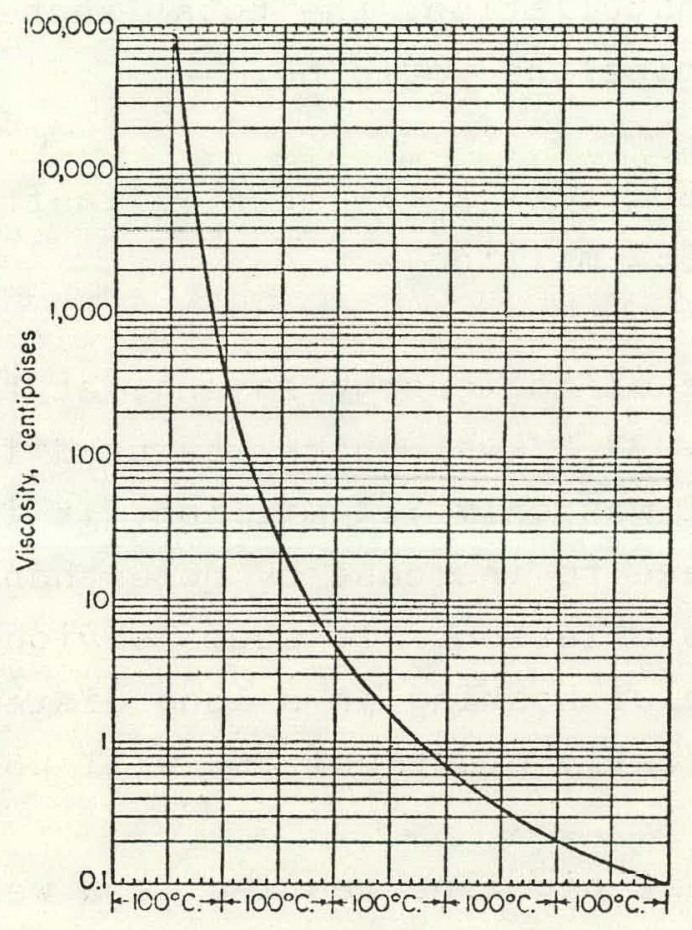

Figure 8.1-3 Approximate temperature variation of liquid viscosity.

Source: Reference 47 
To assess the economics of heating pipelines to reduce friction Losses, discussions were held with pipeline heating system contractor representatives. They indicated that such systems range in cost from about $\$ 1$ to $\$ 5$ per diameter inch per linear foot of pipeline, depending on the location of the pipeline, the temperature/ viscosity characteristics of the fluid pumped, and a variety of other factors. (Refer to Table 8.0-1)

Using the most optimistic estimate of $\$ 1 /$ diameter inch/linear foot for the heating installation, the total increase in capital cost of reference the pipeline would be:

$$
\begin{aligned}
24 " \text { diamelel } \times & 5280 \mathrm{ft} / \mathrm{ml} \times 686 \mathrm{mi} \times \$ 1 / \mathrm{in}-\mathrm{ft} \\
& =\$ 87 \mathrm{million} .
\end{aligned}
$$

Since the present value of the energy saving, at the postulated 20year average cost of $0.037 \$ / k w h r$ which was used in the comparison of l'able $8 . U-1,1$, 11 was only $\$ 14$ million, it is seen that the cost of energy would have to increase by more than a factor of six to even pay for the installation. It seems obvious from this comparison that the use of heating in a long distance petroleum pipeline is not economically practical and will not be in the foreseeable future.

It is concluded that pipeline heating is a well established technology for assisting in the pumping of viscous liquids for relatively short distances, but would not be economically attractive for long distance pipelines until energy costs were much greater than present and also until insulation costs were less.

8.2 Internal Coatings to Reduce Viscosity

Results of various tests and applications over the past 30 years have proven that internal coating of pipelines is an effective method of increasing pipeline flow efficiency. In addition to increased throughput, internal coatings provide other advantages including: protection against corrosion; reduced cost of scrubbers, strainers, pigs, and other types of pipeline cleaning equipment; 
prevention of contamination from corrosive products; reduced maintenance and labor costs; protection of pipe interiors against accumulation of foreign materials; and reduction of leakage from pipelines.

Epoxy-type internal pipe coatings are currently being used in pipe for transmitting dehydrated natural gas, wet gas, crude oil, sour crude oil, salt water, fresh water, and petroleum products. Thousands of miles of internally coated pipelines are in service, with pipe sizes ranging from 2 inches to 42 inches.

Two principal methods of application are employed for internal pipe coatings - "in situ" (or "in-place"), and spraying (Ref. 48). In-situ coating is applied to lines already laid and avoids the welding problem. Historically, the first coating of this type was carried out in 1947-47 in sour crude and sour gas gathering lines. The first in-situ salt water lines were coated in 1953, and potable water the following year. In-situ coating is a highly specialized procedure, and only a few companies operate in this field; however, as a result of experience in North America, Europe, and other areas, ample background is now available, enabling the in-situ coating applicator to use a proven coating, specifically selected for the particular service requirements.

Spray application of internal pipe coatings to individual joints of pipe is the second procedure. Suitable spray and cleaning equipment is available today for internally coating small- and large-diameter pipes, with appropriately formulated epoxy-type coatings, following sound surface preparation such as abrasive blasting or acid cleaning.

The largest spray application of epoxy coatings is for internal coating of natural gas lines. The requirement here is not primarily to give a protective film, but to provide a smooth coating to improve throughput. A thin film, on the order of $1.5-2$ mils, is applied, following surface preparation by a rotary wire brush. Complete maintenance of film integrity is not essential for this usage, and the welds will inevitably not be fully coated. 
Internal coating of gas transmission pipelines started in 1953. At the inception of this development, many questions were raised as to whether the coatings used would have the necessary properties, and whether the cost of internal coating would be offset by the resultant benefits. These questions have been largely resolved by close cooperation between coating manufacturers, gas transmission companies, and engineers.

of the many tests made to evaluate the advantages claimed for internally coated pipe, the most elaborate have been those concerned with increased throughput. Extensive work has been carried out to measure the smoothness of pipeline internal surfaces, both uncoated alid cualed.

In 1955 the Institute of Gas Technology (IGT) conducted a project titled "NB-14 - Internal Coating of Pipe", under the sponsorship of the pipeline research committee of the American Gas Association. Its purpose was to evaluate the feasibility of internally coating pipe for gas pipeline service. As part of this program, some 10 different generic resins were evaluated, involving 25 coatings, including vinyls, alkyds, polyvinyls, furanes, coal tar epoxies, phenolics, and neoprene coatings. Results showed the superiority of the epoxy-based type.

A related project, No. NB-13, was established by the pipeline research committee at IGT to investigate pipeline flow efficiencies. The results of this study showed that, for the ranges of flow and Reynolds number encountered in most large-diameter pipelines, the flow efficiency is dependent on pipe roughness and independent of Reynolds number. As part of its work, the pipeline research committee developed a new flow formula in which the effective roughness of the pipe is used as a factor. The following table compares flow efficiency with effective surface roughness of 36-inch pipe based on this new flow formula. 
Type of $36 "$ pipe

Internally coated

Very smooth commerical

Average commercial

Stored
Effective surface

roughness (in.)
Pipeline flow

Efficiency (\%)
0.00028

0.00045

0.007

0.0013
103.8

100

96.5

91.6

During this same time period, Transcontinental Gas Pipeline

(Transco) conducted an experimental test program on 1199 miles of internally coated pipeline ranging from 20 to 36 inches in diameter (Ref. 49). Various percentages of pipeline were coated on different sections. Epoxy resin type coating was used, since engineering studies had indicated it to be the most desirable for the purpose; the results of NB-14 confirmed this thinking.

After the first internally coated pipe was installed in 1955, the pipeline flow test data failed to reveal conclusively that internal coating was economically justified. For the next two years, the flow tests showed some indication of increased efficiency and were encouraging enough to Transco management to continue the program to the extent of designing for and considering the effects of internal coating on all main line additional facilities for expanding their system. Costs for cleaning the pipe and applying an epoxy coating varied considerably due to methods of manufacture, rate of production, and other factors. However, a general rule of thumb at that time for estimating costs of materials, application, and handling was to allow one cent per diameter inch per linear foot, with the smaller sizes of pipe running slightly higher. Another project conducted during the late 1950's involved a series of tests on an 11.9-mile section of 24-inch OD $\mathrm{x} .25$-inch WT pipe which had been in continuous service in the Tennessee Gas Pipeline Co. system for 10 years. The test were part of a joint 
project under the auspices of eight gas pipeline companies and two companies specializing in pipe coatings (Ref. 50). The project was organized in three phases:

Phase 1 - The section was tested after 10 years of operation.

Phase 2 - The section was cleaned with two separately run wirebrush pigs, and tested after cleaning.

Phase 3 - The section was cleaned with two wire brush pigs, followed by a 3000-gal. plug of Ketone as a detergent. The line was then coated with an epoxy and tested.

The results of testing at various flow rates in each phase shnwed that pipeline deliverability was increased by approximately 5 to $10 \%$, depending on the rate of flow. This increase was broken down to a nearly constant $4 \%$ increase directly attributable to the cleaning operation of Phase 2 and an additional 1 to $6 \%$ indirertly attributable to the work done in Phase 3.

'l'he tests satisfied the overall objective of the project, which was to answer the question of whether the condition of the internal pipe surface has much of an effect upon the deliverability in a large-diameter pipe in commercial service. This question is anwered by examining Fig. 8.2-1. The total increase in the transmission f'actor, which is directly proportional to deliverability, varied from approximately 5\% at a Reyonlds number of 7 million to about $10 \%$ at a Reynolds number of 18 million. The tests were repeated on the internally coated pipe in December 1959 (a year after the original tests) and, as indicated in Fig. 8.2-2, the results showed good correlation with the previous test results. From this is was concluded there had been no apparent deterioration of the interior coating.

A significant recent application was recorded in 1973 when Signal $0 i l$ and Gas Co. completed the in-place internal coating nf an offshore gathering system. Included in the system were $31 / 2$ milcs of two 12-inch and one 10-inch lines connecting platforms, 
and a 21.3 mile, 12-inch main line. All lines were internally coated with a polyamid-activated epoxy. Cleaning and coating operations on the gathering lines were carried out simultaenously from the platforms, and, on the main line, from a platform and an onshore site. Despite the fact that underwater tie-ins were involved, the use of divers were not required.

Another potential application for epoxy coatings is for protection against corrosion and metal loss within the interior surface of slurry pipelines. A recent paper (Ref. 51) evaluated alternative methods for corrosion control against various system parameters including capital cost, operating cost, and user suitability, environmental effects, effects on transport system, and flexibility. The alternative methods considered were heavy wall pipe, thin wall pipe with inhibitor, thin wall pipe with lining, thin wall pipe with oxygen removal, and thin wall pipe combination. The two methods involving internal coating, i.e., thin wall pipe with lining and thin wall pipe combinatio, ranked the most favorably on a cost comparison basis. The evaluation of thin wall pipe with lining was generally favorable otherwise except for concern expressed in assuring a continuous coating free of pinhole leaks. The cost figures for thin wall pipe with lining were based on applying 20 mils dry film thickness of epoxy lining. There is reason to believe that amply protection for a 25 to 30 year operating span could be provided with only 9 to 12 mils thickness of epoxy lining, which would make the cost comparisons even more favorable.

A current rule of thumb for estimating the cost of internally coating a new pipelie, as indicated by contact with one of the leading coating companies (Ref. 52) is to use 15 cents per diameter inch per lineal foot for 6 mils thickness of epoxy coating, applicable to water, gas and petroleum products. For slurry, the figure would be 25 cents per diameter inch, based on 20 mils thickness of 


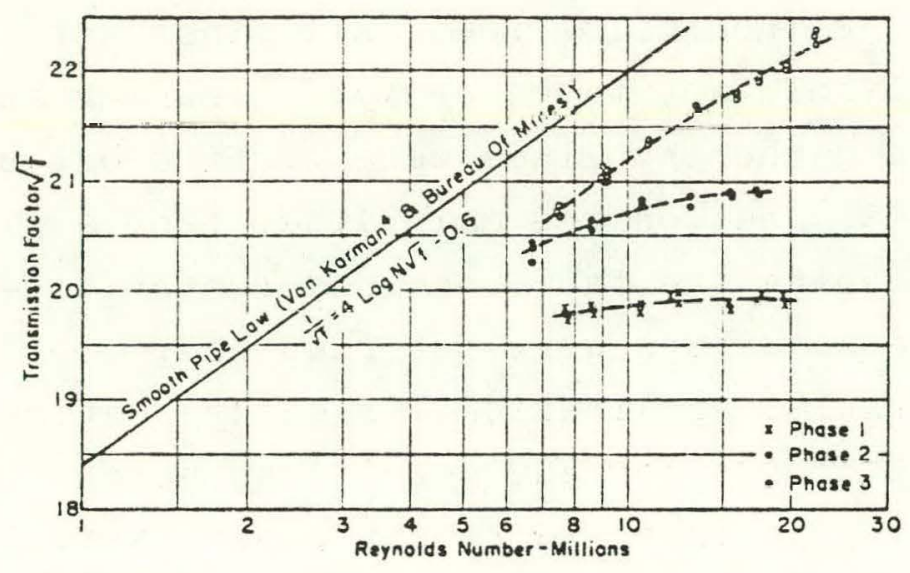

Figure 8.2-1 Performance on oriqinal tests, November and December, 1958.

Phase 1 - After 10 years operation

Phase 2 - After cleaning with wire brush piqs thase 3 - After internal coating

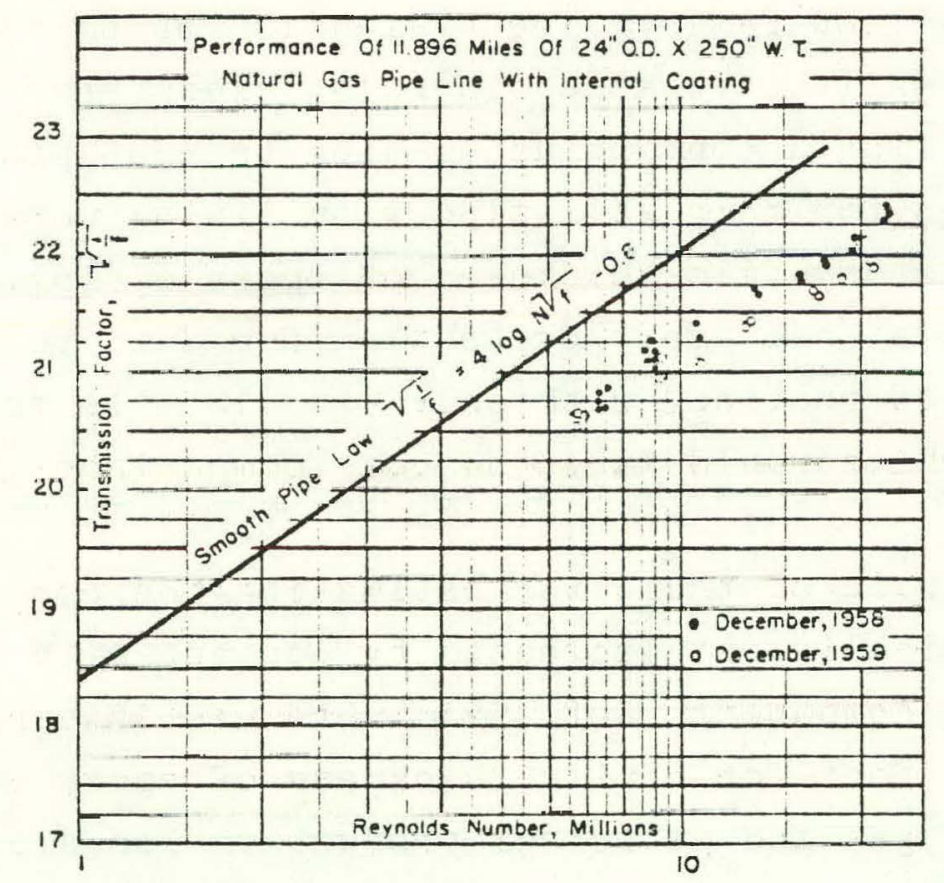

Figure 8.2-2 Performance of the same pipe one year after the tests described in $\mathrm{Figure} 8.2-1$.

Source: Reference 50 
coating. These figures would apply for relatively short lengths of pipeline (up to 10 miles) and would be somewhat less for long pipelines. For in-situ coating of existing pipelines, there is no reliable formula for estimating costs, because of the highly variable nature of the cleaning and processing required.

\subsection{Additives to Reduce Viscosity}

The use of soluble additives to reduce the pressure loss associated with flow through pipes and tubes has been studied intensively since 1964. Although the data are confusing and sometimes contradictory, the indications are that a significant drag reduction can be obtained.

The theoretical basis for drag reduction by additivies generally derives from modifications to the boundary layer of the flowing fluid. In the case of solid additives, particles with a high length-to-diameter ratio are apparently more effective than particles with other shapes. Several investigators attribute this to the alignment of the lenticular particles parallel to the direction of flow and the resultant modification to the laminar and transitional boundary layer adjacent to the channel wall. In the case of soluble additives, a similar phenomenon on a molecular level is postulated, since experimentally it is found that longchain organic molecules have the most pronounced effect.

The most convincing explanation for the phenomenon of drag reduction is that propounded by P.S. Virk (Ref. 53). His model is hased on flow experiments with water as the solvent and with solutions of polymers at concentrations up to $300 \mathrm{ppm}$. The results of these experiments agree qualitatively with carefully conducted experiments by $R$. J. Hansen et al. at the Naval Research Laboratory, also with water as the solvent (Ref. 54). Experiments with organic solvents (Ref. 55) are also in qualitative agreement.

At a Reynolds number of 10,000, the minimum friction factor attainable through drag reduction, according to Virk's equation, is $36 \%$ of the Newtonian friction fractor; this is equivalent to a $64 \%$ reduction in pressure drop and pumping energy. 
Virk's model postulated an elastic sublayer between the usual laminar boundary layer and the turbulent core; the hypothesis is that all drag reduction is related to the thickness and properties of this intermediate flow region. Historically, the analysis of friction losses in flow systems starts with the velocity distribution across the channel. For flow in pipes and tubes, a wide range of data is correlated in terms of universal velocity ( $\mathrm{U}^{+}$) and position $\left(\mathrm{y}^{+}\right)$paramters as shown in the semilog plot of Fig. 8.3-1, taken from Brod (Ref. 56).

For a Newtonian fluid in turbulent flow, two principal flow regions are observed as indicated by the curve A-B-N. In cases where drag reduction is observed, the Newtonian turbulent flow line is displaced parallel to the line $B-N$ to form a velocity profile such as $A-B-C-D$, consisting of three flow zones: the turbulent core, the laminar boundary layer, and the intermediate "elastic" layer with the thickness represented by the horizontal "distance" betwen the points B-C.

The characteristics of drag reduction can be seen from this figure. The primary effect is that a higher mean velocity is observed for the same friction factor. This desirable effect apparently is a result of the significantly lower specific enregy required to sustain turbulent flow of the system in the presence of the additive. The mean velocity increases above Newtonian velocity across the intermediate elastic sublayer, which extends from about $15<y^{+}<60$. This effective slip is the explanation for the drag reduction phenomenon, according to Virk's model.

For practical application of drag reduction to design, the usual correlation of friction factor with Reynolds number is used, being derived by integration of the velocity profile of Fig. 8.2-1 over the cross section of the duct. The form of this correlation is: 
FIGLRE 8.3-1 SCHEMATIC OF THE MEAN VELOCITY PROFILE DURING DRAG

REDUCTION ACCORDING TO CLASSIC SUBLAYER MODEL

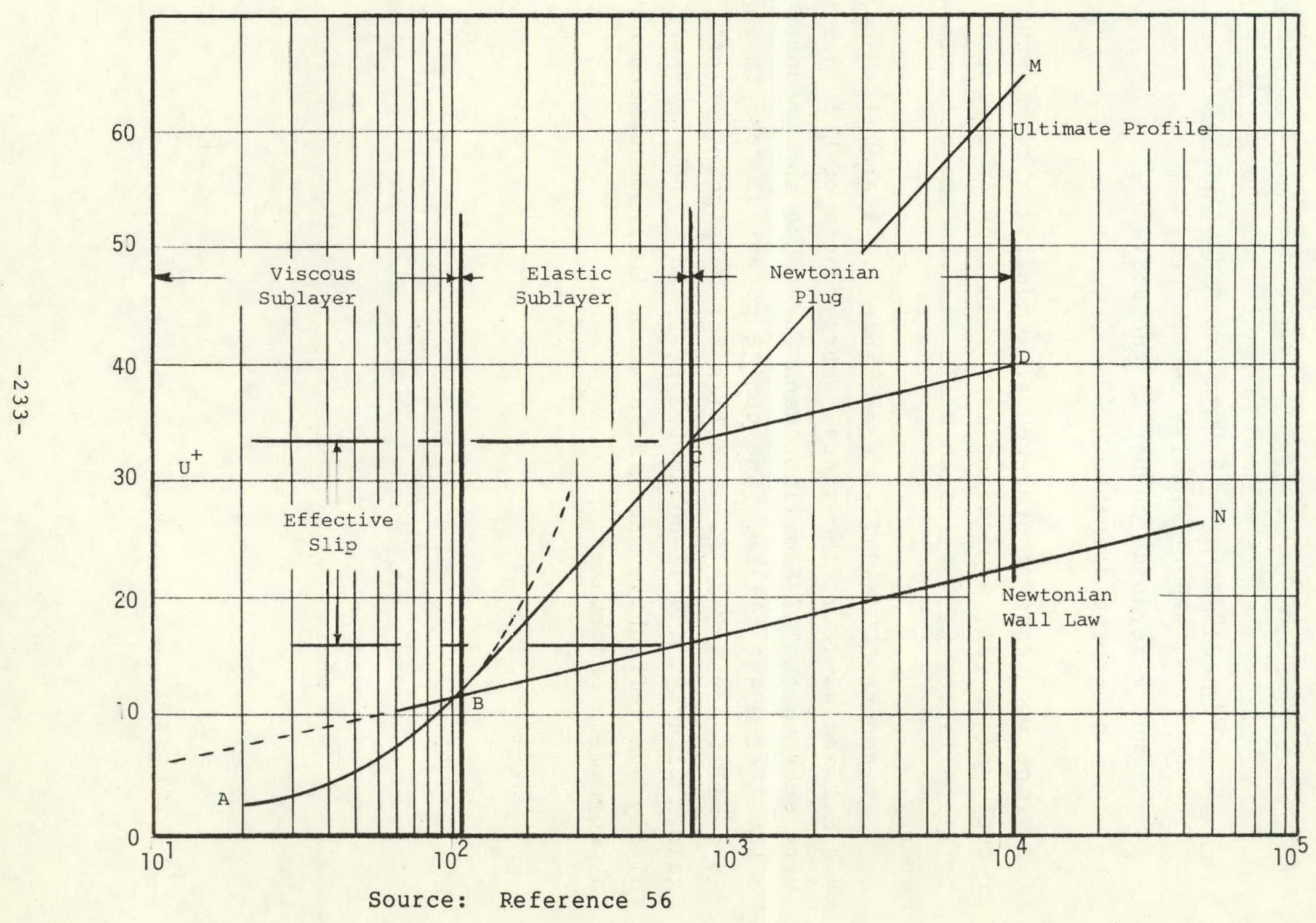




$$
f^{-\frac{1}{2}}=(4 \cdot 0+\delta) \log _{10}\left(\operatorname{Re} f^{\frac{1}{2}}\right)-0.4-\delta \log _{10}\left(\sqrt{2} \mathrm{dW}^{\circ}\right)
$$

where

$$
\begin{aligned}
\delta, \mathrm{W}^{\circ}= & \text { parameters of the drag reduction system } \\
& \quad \text { experimentally determined } \\
\operatorname{Re}= & \text { Reynolds number of the solvent } \\
\mathrm{d}= & \text { pipe diameter. }
\end{aligned}
$$

Pipeline tests of drag-reducing additives have shown viscosity reductions of $48 \%$, equivalent to a reduction in turbulent flow friction factor to $15 \%$, which would also be the reduction in pump telletgy.

In report $\mathrm{HCP} / \mathrm{M}-1171-2$ (see Table 1.1-1 above), Sections 4.4.2.2 and 4.5.2.2, the annual energy costs of U.S. oil pipelines were seen to be 127 \$ miliion each for crude and products lines, or a total of 254 \$ millin. The upside potential cost saving is thus 38 \$ million/year, or 2.5 \$ millin for each point of efficiency gain. Clearly, a well-conducted R, D and D program should he highly cost effective, and it is accordingly recommended that such a program be undertaken. 


\subsection{OTHER IMPROVEMENTS}

9.1 Cybernetics of Pipeline systems

Cybernetics is a term coined by Norbert wiener as a name for the science of information and control in complex systems. The science is now a well developed body of knowledge which is applied to practical systems through high speed, large memory computers which assume many or all of the functions previously performed by human operators. Automation is a term which is often applied to this process.

The three major functions within a cybernetic system are:

1) The collection of information relative to the state of the system.

2) The processing of that information, along with whatever operator input may be required, through an algorithm which calculates the necessary control action.

3) The effectuation of the necessary control.

Functions 1 ) and 2) involve information and control only, and. they can be performed by equipment which performs no other function and therefore operates independently of the pipeline system. This equipment is generally electronic, e.g., microwave communicators and high-speed computers. However, function 3 must be performed by equipment which is part of the pipeline system proper, i.e., motors, engines, pumps, valves, etc., and therefore performs noncybernetic functions as well.

Earlicr, Section 4.3.6.1 presented a detailed discussion of duty cycles in product pipelines. There it was seen that such pipelines operate at steady state only when the entire linefill is a single product. However, this situation is seldom obtained, and therein lies an opportunity for energy conservation. The existence of that opportunity was identified in section 4.2.2, and the recommended approach to lifting of equipment limitations and solution of the associated problems was presented in section 4.3.6.2. However, those discussions only treated function (3), the effectuation of necessary control, and showed that the objective is 
infinitely variable pump speed control, and recommended the fuel cell-DC motor approach. The cybernetic functions (1) and (2), the communication and control luncliuns, still romain to be adiressed. As noted earlier, these functions are generally performed by electronic communciations equipment and high-speed computers. The following discussion of these applications is taken from Carter (Ref. 57).

Pipeline scheduling involves collecting and processing information from all shippers desiring movements as to the grade and quantity of the material to be muved, its origin and destination, and the approximate timing to assure that the various movements will arrive at the proper destinations on a timely basis.

After the schedulers have completed their work, they normally present a monthly schedule of movements to another group of people to handle the day-to-day, hour-to-hour, minute-by-minute activities necessary to carry out the schedule. These people are usually called dispatchers. Their functions and responsibilities are 1 isted below.

1. The dispatcher must be assured that the material he receives is of proper quality and grade.

2. The dispatcher must accurately measure the volume received for each shipper and liedit it to his account.

3. The dispatcher must keep accurate ducuints of thc location of the head-end and tail-end of each batch of fluid moving through the line.

4. A dispatcher must deliver the proper amount of the right grade and quality product at the right destination for each shipper.

5. A dispatcher must be assured at all times that his inputs equal his outputs, taking into consideration the fluctuation of workiny lankage.

6. All movements through a pipeline system must be accounted for and the proper charge assessed to them.

This dispatching function is the 24-hour/day, 7-day/week, nerve center of all pipeline systems. Dispatchers have at their 
fingertips the means for checking amounts of inputs and outputs and the flow through the pipelines by reading meters and gauging tanks remotely. They must have constant check on pressures to keep from bursting the pipelines. The quality and grade of the petroleum moving through the lines is known at all times through remote reading gravitometers, BS\&/W (basic sediment and water) monitors and other similar devices. All these are data needed by the. dispatchers to evaluate and assure them the line is running properly and safely. The dispatchers direct tank farm personnel in switching tanks of $f$ or on the system and are in constant communciation with deliveryman and guagers, giving instructions as to the time, quantity and quality of material to be delivered at locations throughout the system. Practically ali the work done by a pipeline. company is dependent upon effective dispatching.

The dispatching operation is being automated in various ways by each pipeline company by using the electronic innovations of our. day. In the early 1970's, pipe line companies advanced beyond the dispatching operation just described to a centralized Control Center operation. This Control Center combines the tremendous calculating capacity and data handing ability of the computer with the logic of the scheduler and the minute-to-minute instructions and logic of the dispatcher.

The use of computers and automation in the area of pipeline. operations and control has been growing almost exponentially since the mid-1960's. A 1973 Survey on Computer Usage by the API showed that $57 \%$ of the pipeline companies were using computers for some type of operational application and that $33 \%$ were using computers for data acquisition and control. This compares with only $34 \%$ of the companies using computers in operational areas in 1962.' In 1962 there were no on-line computer applications in the pipeline industry, and only three companies were studying on-line data acquisition in the mid-sixties. 
On-line computer installations, such as that illustrated schematically in Figure 9.1-1, for data acquisition, dispatch calculations, and control are commonplace. In the future, they will be extended to all types of data. In addition to the present on-line readings for tank gauges, meters, temperatures, pressures, gravity, orifice flow rate, and interface detection, there will be on-line readings in the future for BS\&W sampling, viscosity, vapor pressure, flash point, and even friction loss coefficients for dynamic hydraulic calculations. The principal advantage of on-data acquisition, is, of course, that it is much faster than obtaining telemetered reaāings by manual aisplay, or over the phone for copying, and it is also more accurate. By 1974, 18 companies were known to have on-line aata acquisition applications representing some 4000 on-line readings.

Dispatching calculations performed at a central computer location offer a tremendous advantage, especially when coupled with on-line data acquisition, because the computer can make these calculations both rapidly and accurately. 'l'hese are the basic types of dispatch calculations for keeping track of tankage and line inventory, calculations for receipt and delivery volume movement into and out of the line, line fill update (or batch tracking), batch arrival time, and line over and short calculations. In 1974 there were five cumpanies that reported doing some type of dispatch calculations using online data. 
ON-LINÉ COMPUTER INSTALLATIONS WILL BECOME COMMONPLACE

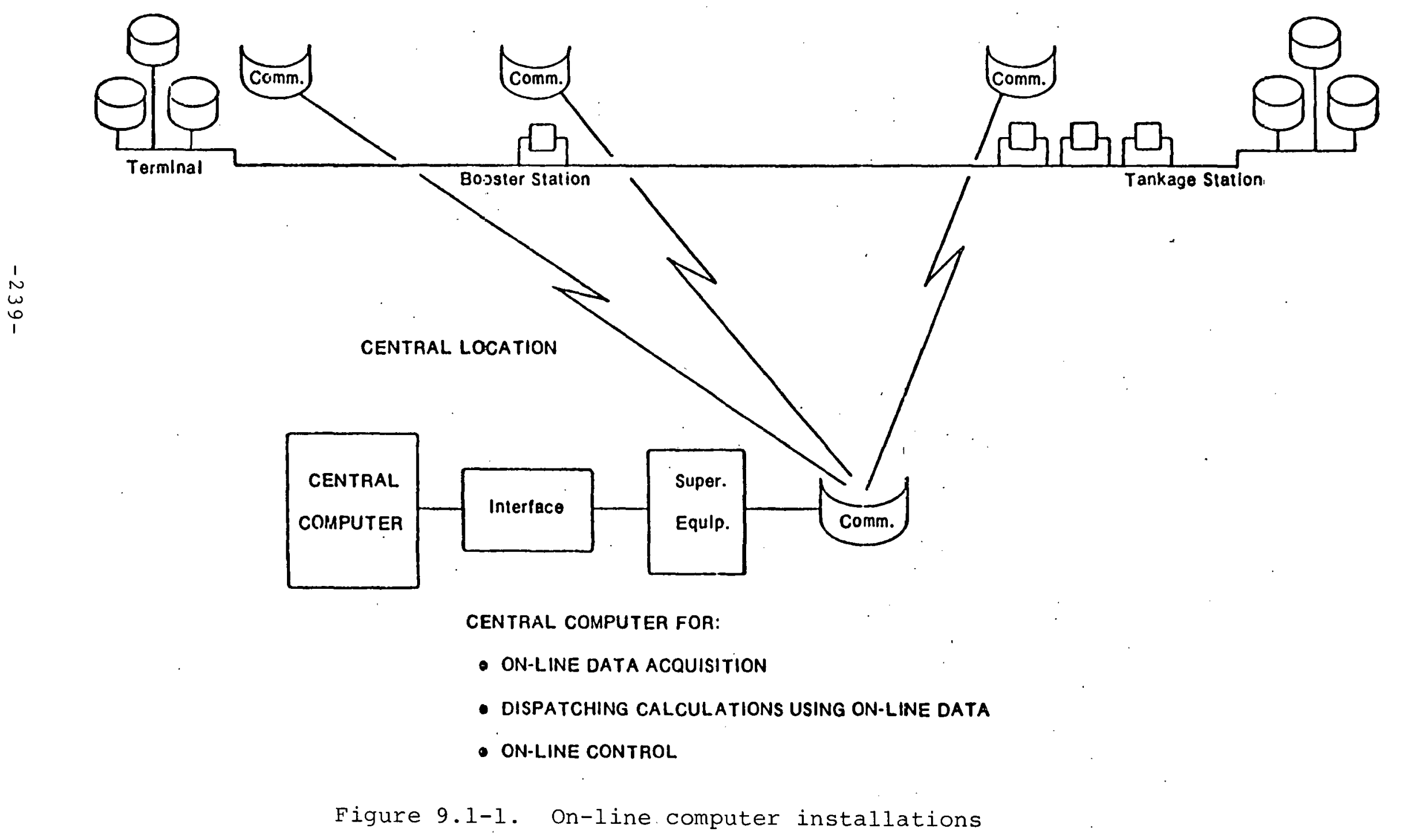


There are definite advantages in having the remote unattended pump stations connected to the central computer for on-line control and interrogation of supervisory control status functions, as illustrated in Figure 9.1-2. Supervisory control equipment can be defined as equipment for controlling and supervising the status of some device, such as a motor or valve, over a communications circuit. The same equipment is used to telemeter pressures, temperatures, or tank gauges. The computer in this case has the ability to communicate with the remote control functions, and programs may be designed to perform certain control functions such as starting a pump unit at a specific time; or the program may or may not entail closed-loop operation. The computer can be tied to the remote supervisory control equipment to control pumping units, valves, and set-point controllers as well as to pick up supervisory status of alarms, pumping units running,etc. Another advantage of on-line control is that status information can be internally stored in the computer for hard. copy output and records.

In 1964, ARCO Pipe Line installed what is believed to be the first on-line computer control system in the liquid pipeline industry. The operation of the system has been very successful and it has proved to be an economically justifiable endeavor. The system encompasses some 3200 miles of crude and products pipelines, 450 data acquistion points for tank gauge, meter, temperature and pressure readings, and performs 


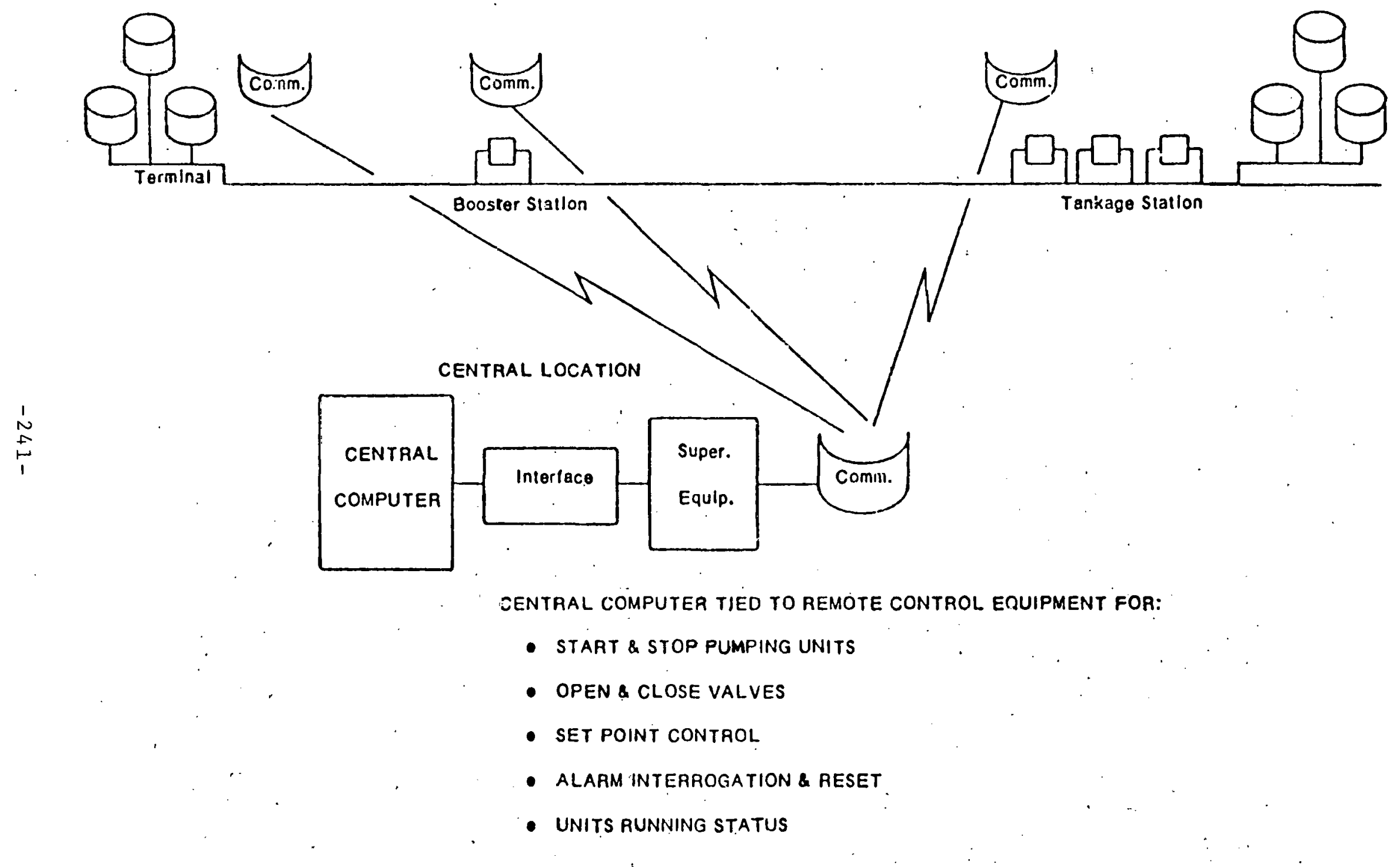

Figure 9.1-2.,- Remote computer control of unattended pump stations 
some 370 independent supervisory control functions, including alarm and pumping units running status interrogation.

As technology and programming systems are developed, more and more sophisticated closed-loop programs are being implemented for controlling starting and stopping of pumping units, automatic switching of tankage and terminal manifold valves, pressure and flow set point control, and controlling upset conditions in general by closed-loop action. Some of these functions are illustrated schematically in Figure 9.1-3

closed-loop control on the pipeline means that the computer, through its program logic, senses a condition and instigates some type of controlling action on its own without manual intervention. There can be varying degrees of closedloop control. Pipeline segments may have only partial closedloop control for a few functions, or the entire system may be under closed-loop control. The control may vary from a simple set point control of a suction pressure based on on-line calculation for arrival time of a different product, to the ultimate in which a schedule determines the clused-loop action for starting and stopping the pumping units, switching manifuld valves, controlling optimum pumping units, and automically handling upset conditions. From a safety standpoint, closedloop operations give faster reaction-control than manual operation in sensing upset conditions, e.g., pressure surges and other abnormal operating conditions, and in taking corrective action.

ARCO Pipe Iine Company has a 185-mile section of 8-inch line from Western Oklahoma to near shawnee, Oklahoma, which has nine injection stations on closed-100p control, as shown in Figure 9.1-4. This line handles a low vapor pressure crude and condensate and a high vapor presssure stream of natural gasoline 


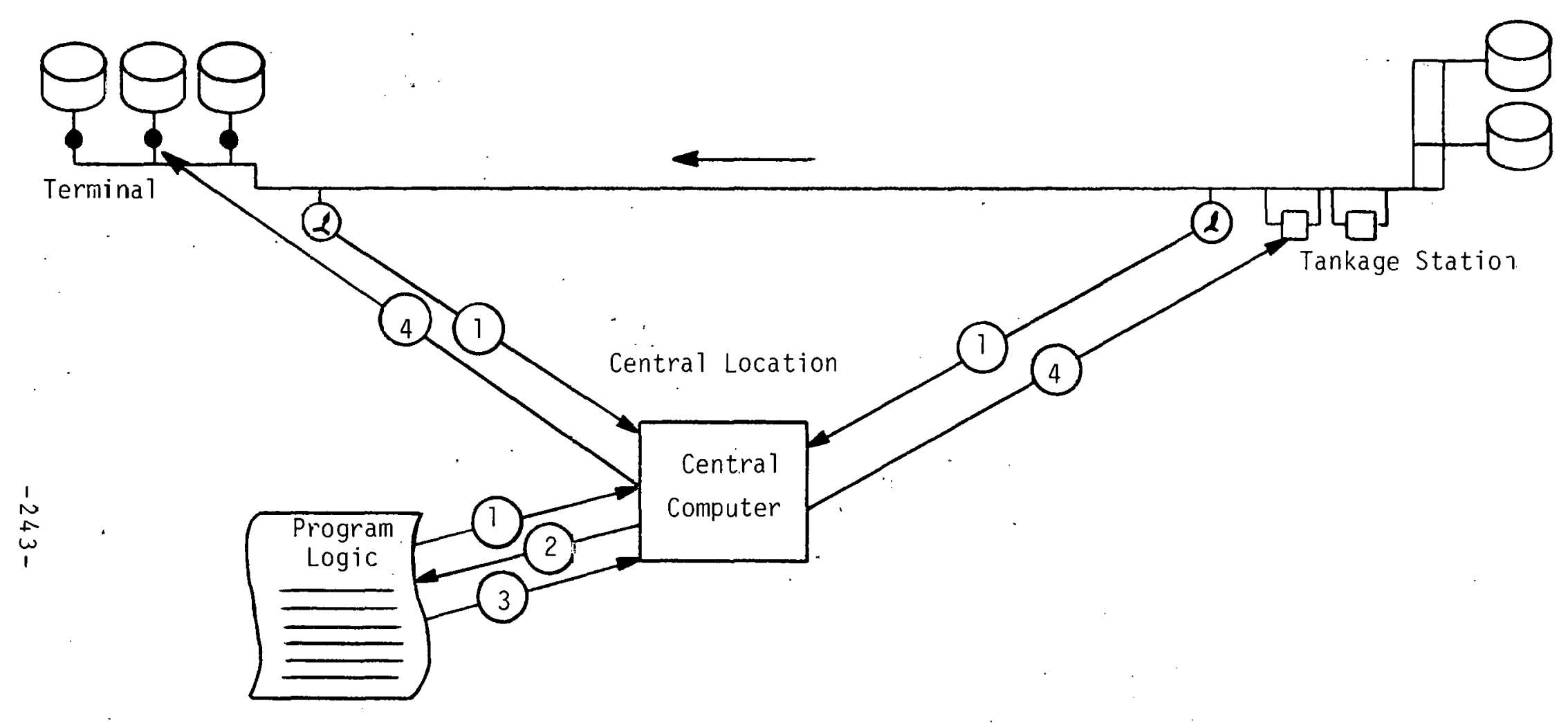

CLOSED-LOOP CONTROL:

(1) SENSES CONDITION (IN FIELD OR BY COMPUTER PROGRAM)

(2) program makes calculations, analyzation

(3) PROGRAM CALLS FOR COMPUTER ACTION

(4) COMPUter instigates ACtion OR CONTROL

FIGURE 9.1-3 CLOSED-LOOP COMPUTER CONTROL OF PIPELINE SYSTEM 


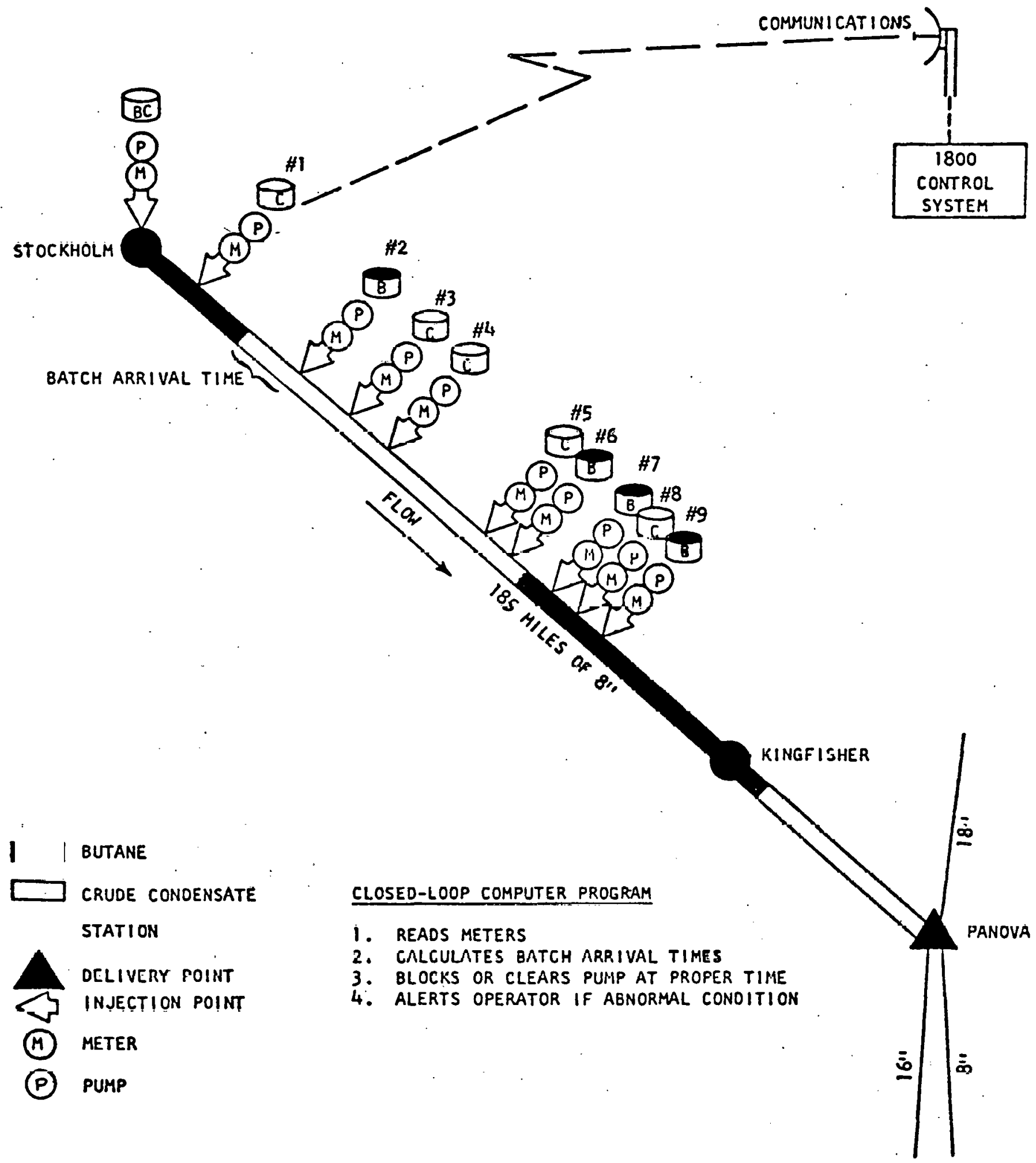

Figure 9.1-4 ARCO Western Oklahoma crude condensate line block-clear computer control program 
and butanes. The material from each of the nine points must be injected into the proper batch of compatible material as it passes the injection point. The computer control system reads the various meter readings, calculates the updated line. fill and batch arrival times, determines if and when a pumping unit is to be started or stopped, and then initiates closedloop action to block or clear the injecting pumping unit at the proper time. The program also alerts the operator to any abnormal conditions that are detected.

The fastest-growing current recent development in the use of computers for pipeline automation is the use of the minicomputers. Figure 9.1-5 illustrates the application potential

ARCO has an IBM System/7 computer at their Humboldt, Kansas, Tank Farm pump station. This computer is designed to:

1. Effect station control

2. Acquire data

3. Maintain surveillance of operating conditions and protective controls

4. Transmit data to and receive data from the central IBM 1800 system computer at Independence.

Humboldt station is a relatively simple tank pump station operation. The station has 4 main line pumping units, 3 booster pumps, 14 tanks with tank mixers, and 2 positive displacement meters with meter proving facilties. The station operates on a 24-inch pipeline system, handling 6 grades of crude oil.

The computer is programmed to perform a majority of the operating functions presently being done by the man. The most unique function the computer will do is the sensing of gravity of the incoming streams to appropriate tankage as required. This and other functions programmed into the computer will 


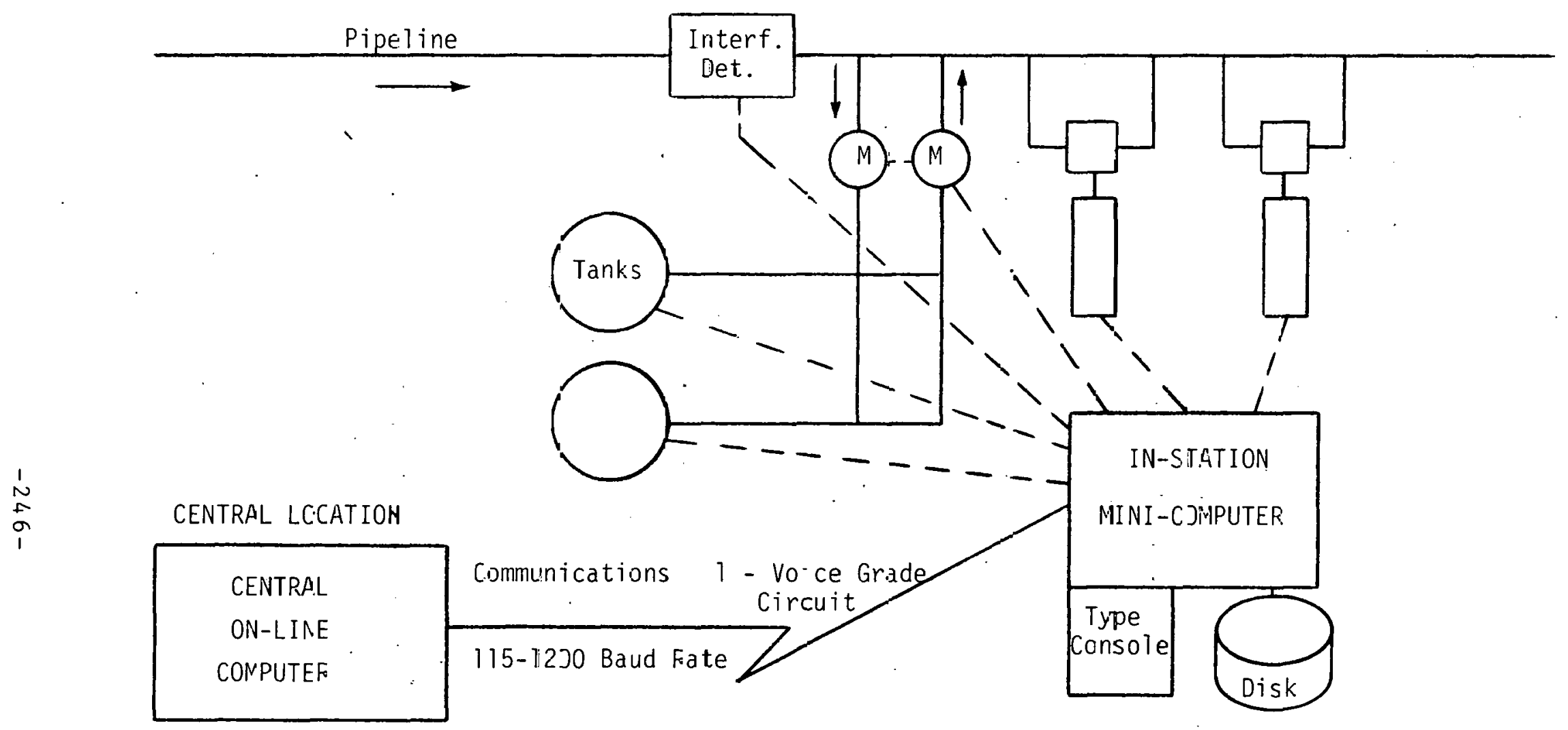

- Switch Tankage llanifold Valves

- Batch Interface Detection

- Start anc Stop Pumping Units

- Vapor and Fine Detection and Control

- Data Acçlisition:

- Tank Eauge, Meter, Temperature, Pressure Feadings

- Surveiilance and Analyzetion of Station

- Programmed for "Safe" Operation:

- If Communizations Out to Central Location

- For Upset sonditions Operatirs Conditions

=IGURE 9.1-5 MINI-CCMPU-ER IN-STATION CONTROL AT TANKAGE LOCATIONS 
permit unattended operation at the pump station except for daylight maintenance, housekeeping and custody transfer functions.

The computer is interfaced to the existing pipeline station equipment and instrumentation, both analog and digital, in four major categories, according to type of operation :

1. It functions as a station controller by switching tankage manifold valves, based on schedules supplied by the central computer or by interface detection from the gravitometer of the incoming line. It also starts and stops main line pumping units, booster pumps and tank mixers on a schedule supplied from the central computer.

2. The computer acquires data from tank gauges and meter readings each hour or on demand, and pressure readings, temperatures, gravitometer, sump tank level, etc.

3. The computer operates as a surveillance devicé of the critical station operating conditions for safe control. It reads pressures, temperatures, sump tank levels, checks operating limits, and takes necessary action if any of these readings are out of predetermined limits. It checks pumping unit running conditions and valve positions every minute. It detects abnormal operating conditions such as excessive pump unit vibration, excessive seal leakage, high. . tank levels, etc., and takes whatever corrective action is necessary. If corrective action is necessary, the computer alerts the control Center operator at Independence of the malfunction 
condition and in some cases places a telephone call to an on-call station attendant in Humboldt.

4. The computer is tied directly to the central on-line computer in Independence by microwave communications and relays various instructions for pumping schedules, batch arrival times, pump unit start and stop schedules. It also transmits hourly data on volumes received and pumped, tank levels, pressures, temperatures, and any pumping unit or valve changes.

The basic pump station design is such that in the event of any failures, a safe condition is maintained.. This basic analogy is also carried through to the programs within the instation mini-computer, and the operation of the pump station continues in a safe manner if the computer also fails.

Eventually computers will become the heart of complete management information systems whereby on-line data, operating information, and billing data of each shipper will be directly available to those shippers that are equipped to use it. All major operating records and statistical data will be kept on disk storage data files within the computer system for immediate retrieval. There will be CRT display units, or other terminal units, in the pipeline offices of the schedulers, oil movements managers, and financial managers, so that they can call for the latest up-to-date information required to perform their dutles. There will be computer-to-computer tie-ins with computers and terminals at the shipping companies and other pipeline offices for dircot aocces of operating information, for obtaining the latest scheduling information, inventory volumes, and shipping forerasts : 
The foregoing discussion shows that the use of computers to control pipeline operation is a proved and well accepted method of reducing oil operating costs. Additionally, a. literature search revealed that more than 100 articles have been written on the design of, and operating experience with, . automated and computerized gas pipeline systems.

In almost every case, reports indicate that decisions to automate were made after very careful study, and results have been very satisfactory. Some operating companies are retiring existing systems in favor of more sophisticated new systems. In general, computer systems offer system control, optimization, information display and reporting, and telemetry capabilities.

The literature review has also revealed that at least six companies offer automation systems equipment design and/or installation. In many cases the programming of the controllers is accomplished as a joint venture between the pipeline company and the controller supplier.

Some of the major suppliers of compression and pumping units used in pipelines have also developed the capability for. computing physical parameters affecting machinery selection, and have rendered valuable assistance to the pipeline customer in optimizing system contrul.

In view of the well established position of computer optimized control in the pipeline industry and the continuing effort within the industry to introduce further improvements, there does not appear to be any reason for DOE-supported $R \& D$ in this area. 


\subsection{Leakage Inhibitors}

\subsubsection{Leakage in Liquid Pipelines}

Leakage from oil and gas pipelines accounts for a considerable proportion of total operation expenses. It also represents an energy loss, and reduction of leakage is therefore a matter of prime interest in this study.

The ICC does not publish summaries of financial and operating statistics of oil pipelines. However, the individual pipeline companies submit annual reports containing such data to the ICC. These reports contain operating expense accounts which include as one of the items, "Oil Losses and Shortages." Comparison of this figure with the Total Operations Expenses gives an order of magnitude indication of losses due to leakage. Under Task 1 of this study, estimates of total eneryy consumption and of energy intensity were developed and presented in report $1171-2$ (see Table $1.1-1$ above) of this series. Tables 9.2.1-1 and 9.2.1-2 are replications of Tables 4.4-1 and 5.4-1 of that report. A comparison of columns 3,4 , and 5 is interesting for several reasons. First, oil shortages and losses are seen to be significant, i.e., about 6 percent, in comparison with fuel and power costs. Second, they are also a significant fraction, that is, almost 20 percent of non-fuel expense. Third, extreme variations are seen from company to company, in some cases assuming large negative values. In fact, the second largest absolute magnitude in the losses and shortages column is a negative number.

This latter observation indicates that further research would be required before any conclusions and/or recommendations regarding energy conservation can be developed from these figures. Clearly, while the companies are most certainly 
Table $9.2-1$

MAJOR CRUDE OIL PIPELINE COMPANIES - U.S. INTERSTATE TRUNKLINES, 1976

COST IHTENSTTY NHALYSIS

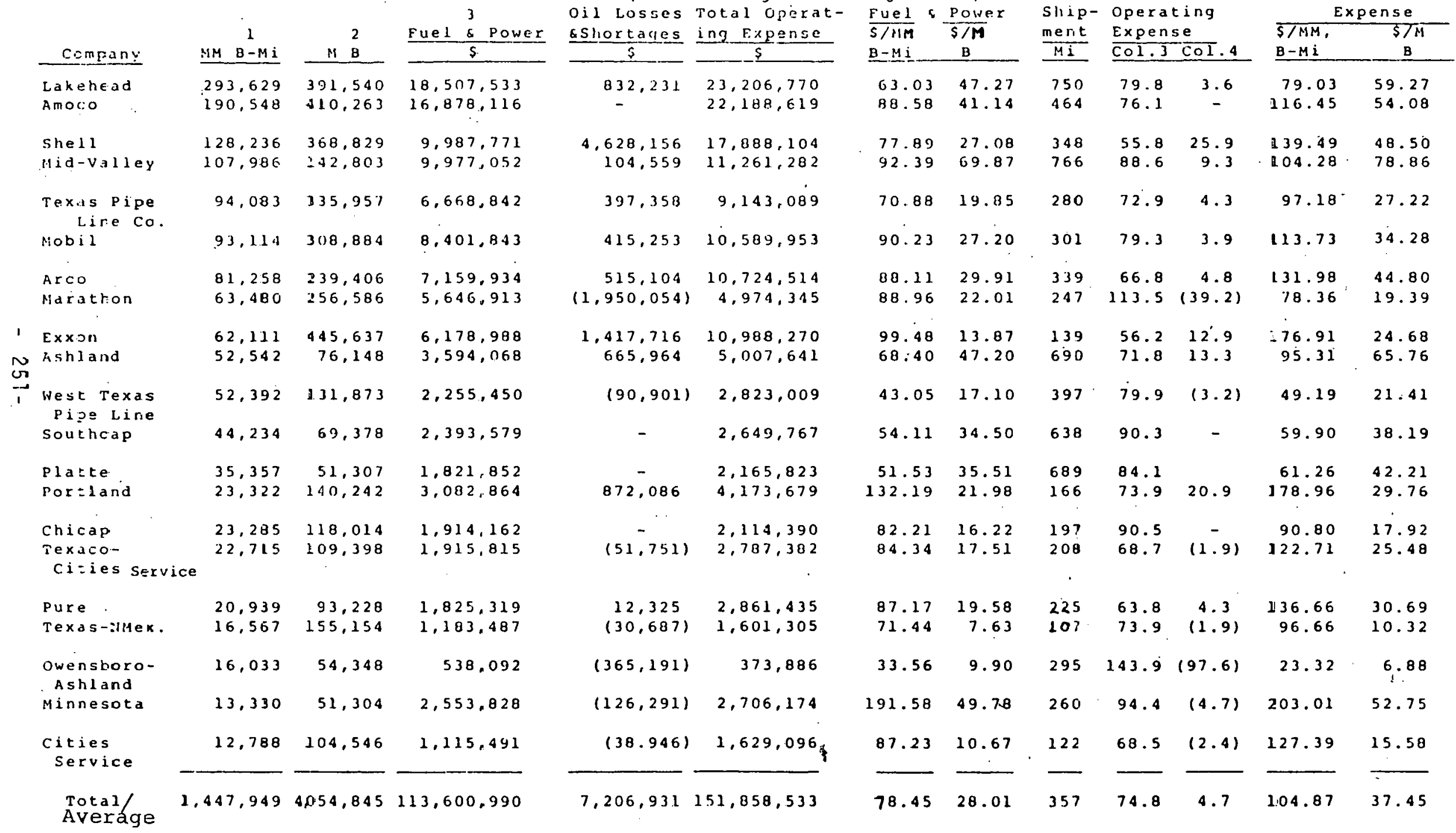

Source: Reference 58 
Tahle $9.2-2$

MAJOR. PETRJLEUM PRODUCTS PEPELINF COMPANIES - U.S. ZRUNKLINES, 1976

\begin{tabular}{|c|c|c|c|c|c|c|c|c|c|c|c|c|}
\hline \multirow[b]{2}{*}{ Company } & \multirow[b]{2}{*}{$\begin{array}{c}1 \\
M M E-M i \\
\end{array}$} & \multirow[b]{2}{*}{$M^{2} B$} & \multirow{2}{*}{$\frac{\text { Euet }:^{3} \text { Power }}{5}$} & \multirow{2}{*}{$\begin{array}{cc} & 4 \\
\text { oil } & \text { Losses } \\
\text { 6Shortages }\end{array}$} & \multirow{2}{*}{$\begin{array}{l}\quad 5 \\
\text { Total. Operat- } \\
\text { ing Expense } \\
5\end{array}$} & \multirow{2}{*}{$\begin{array}{c}6 \\
\text { Fue } 5 \\
\bar{S} / H H \\
B-M i \\
\end{array}$} & \multirow{2}{*}{$\begin{array}{c}7 \\
\text { Power } \\
\text { SiM } \\
\end{array}$} & \multirow{2}{*}{$\begin{array}{l}8 \\
\text { Avg. } \\
\text { Ship- } \\
\text { ment } \\
M 1 \\
\end{array}$} & \multicolumn{2}{|c|}{$\begin{array}{l}3 \text { of rot. } \\
\text { Operating } \\
\text { Expense }\end{array}$} & \multicolumn{2}{|c|}{$\begin{array}{c}11 \\
\text { Total Operatin } \\
\text { Expense. }\end{array}$} \\
\hline & & & & & & & & & $\frac{\text { Expens }}{\operatorname{col} 1.3}$ & $\frac{e}{\cot .4}$ & $\begin{array}{l}\overline{S / F M i} \\
B-i \cdot i\end{array}$ & $\underset{B}{\$ / 11}$ \\
\hline Colonial & 591,583 & 569,396 & $56,50 \leqq, 564$ & 127,388 & $=4,333,213$ & $95.5 \dot{a}$ & 99.23 & 1039 & 87.8 & 0.2 & $10 \varepsilon .81$ & 113.07 \\
\hline Plantation & 105,642 & 206.089 & $9,05 \subseteq, 872$ & 372,162 & $13,632,728$ & 85.76 & 48.69 & 568 & 66.2 & 2.7 & 126.52 & 73.52 \\
\hline Texas Eastern & 65.573 & $\therefore 15,518$ & $5,09 c, 446$ & 657,295 & $9,132,26 ?$ & 77.63 & 44.07 & 568 & 55.4 & 7.2 & 140.03 & 79.49 \\
\hline williams. & 62,463 & $\div 77,781$ & $7,75 E, 856$ & - & $14,039,105$ & 124.18 & 43.63 & 351 & 55.3 & 0 & $22<.60$ & 78.91 \\
\hline "Iid-America & 42,577 & $-03,648$ & $3,9711,866$ & $(478,014)$ & $6,2.9,930$ & 93.29 & 38.32 & 411 & 63.6 & $(7.6)$ & 146.79 & 60.30 \\
\hline Explorer & 33,805 & 59,029 & 1.736 .074 & 623.459 & $3.312,077$ & 51.18 & 29.31 & 573 & 52.2 & 18.8 & $9 \because .98$ & 56.11 \\
\hline $\begin{array}{l}\text { Southern } \\
\text { Pacificic }\end{array}$ & 26,083 & 206,346 & $4,64 E ; 535$ & 67,154 & $8,556,931$ & 178.24 & 22.47 & 126 & 54.3 & 0.8 & 328.49 & 41.02 \\
\hline Dixie & 19,797 & 29,078 & $2,155,141$ & 445,103 & $3,4 \div 3,575$ & 114.65 & 74.12 & 646 & 62.4 & 12.9 & $18 \div .73$ & 118.77 \\
\hline Hydrocarbon & 18,473 & 27.364 & $3,67 C, 318$ & - & $5,252,716$ & 198.67 & 134.13 & 675 & 69.7 & 0 & $28 c_{4} .87$ & 192.32 \\
\hline Nolverine & 13,007 & 83,276 & $2,61 \leq, 420$ & 153.035 & $3,8 \div 5,490$ & 201.05 & 31.41 & 156 & 67.8 & 5.0 & 296.37 & 46.30 \\
\hline Olympic & 12,833 & 68.424 & 935,814 & - & $1,7 \geq 4,286$ & 76.79 & 14.41 & 188 & 57.2 & 0 & $13<.31$ & 25.20 \\
\hline Santa Fe & 9.683 & 20,044 & 265.876 & - & $7,9.54,109$ & 27.46 & 13.26 & 483 & 3.34 & 0 & 821.45 & 396.83 \\
\hline Yellowstone & 8.913 & 20,784 . & 754,969 & $(26.027)$ & $1.2 .19,048$ & 84.66 & 36.32 & 429 & 61.9 & $(2.1)$ & 136.70 & 58.65 \\
\hline Laurel & 8,457 & 42,706 & $5 \bar{x}, 661$ & 699,572 & $2,1+6,303$ & $6.9 .9 a$ & 13.64 & 198 & $\underline{27.1}$ & 32.6 & $25: .79$ & 50.26 \\
\hline$\frac{\text { Total/ }}{\text { Average }}$ & 17,997 & 0.5 .983 & 9.7911 .412 & $2,6 \varepsilon 1,527$ & $145,0 \geq 1,778$ & 98.03 & 58.49 & 597 & 68.8 & 1.8 & $14: .46$ & 84.81 \\
\hline
\end{tabular}

Source: Reference 58 
losing some oil through leaks, the leakage can move only in the outward direction. The presence of large negative values leads then to the inference that the account is some sort of inventorybalancing artifice, rather than an actual tabulation of physical losses. Additionally, it is difficult to see how very large anounts of oil can be lost without some kind of environmental iripact becoming evident. This physically evident consequence, together with the economic drive to minimize losses, should insure that the companies would move aggressively to inhibit and stop leaks.

In view of the foregoing, it is concluded that the information at hand does not warrant a DOE program in this area. Moreover, it is unnecessary to develop further information, because the only method of active leak inhibition that has been identified is by internal coating of the lines, and a DOE program in that area has already been recommended for other reasons in sections 8.2 and 3.7 above. It is thus concluded that further research to understand the implications of column 4 in the Tables is not needed for present purposes.

\subsubsection{Leakaye in Gas Pipelines}

Statistics of interstate natural gas pipeline companies for the year 1974 (Reference 42) show that transmission system losses of all A and B companies (those with annual revenues of $\$ 1$ million or more) amounted to over 68 billion cubic feet. This quantity constitutes 2.4 percent of the total gas receipts for that year. At the current well head price, this loss would be worth over $\$ 100$ million, and its true national value, as defined in section 2.4 of rcport $\mathrm{HCP} / \mathrm{M}-1171-3$ of this series, is about $\$ 250$ million. 
Examination of the "unaccounted for" figures reported by the individual companies reveals that, unlike the oil case, no negative values are reported. Also, in the case of gas, it is easy to see how significant leakage could occur without environmental impact or even detection. The reported figures may thus represent significant physically real, recoverable leakage.

In the past, a large part of the leakage was due to venting during compressor blowdown. With the recent strong emphasis upon conserving gas, the companies have generally taken measures to retain most of this gas.

In Section 8.2 above, it was recommended that further $R \& D$ be performed to realize the energy savings that are potentially possible through the use of internal coatings. This recommendation is reinforced by the possibilities for leakage reduction which have just been identified.

There is ample evidence to show that internal coatings are effective in reducing leakage in pipelines. In one case involving a low pressure gas plpellne, ln-place cualing ledued leakage in a 2-mile section of an old line by over 93 percent (Reference 48). Before coating, the line was tested at 100 psi for a period of 24 hours. Leakage amounled lo 292,000 cubic feet daily. After coating, the same test recorded a daily leakage rate of only 19,000 cubic feet. It was concluded that nearly complete leakage reduction might be achleved by using a larger application pressure and a greater number of coating runs.

One type of coating receiving growing acceptance for pipeline use is the epoxy coal tar coating, consisting of a blend of coal and epoxy resins with a curing agent. By blending the epoxy with coal tar, water resistance of the coating is improved and, by application of sufficient thickness of the epoxy coal tar coating, good leakage resistance is also dehleved. 
As noted earlier, further research would be required to clarify the true significance of the reported figures of unaccounted for gas. However, for present purposes, such research is unnecessary, for the same reasons as in the case of the oil lines. That is, the program of internal coating demonstration that was recommended for other reasons in section 8.2 above will also inhibit leaks if it is conducted with that objective in mind. Since a much thicker coating is required for a leak inhibitor than for a viscosity reducer, in planning the demonstration program it may be desirable to conduct further research into the amount of leakage that exits. 


\subsection{REFERENCES}

1. Anonymous, "Solar Centaur Natural Gas Compresor set", Solar Division of International Harvester publication \#T288/675, 1975 . 2. Anonymous, General Electric Publication GEA-8734, General Electric Company.

3. Gas Turbine International, "Special Report: Gas Turbine on Gas Pipeline" July-August 1974.

4. Heard, T.C., "Reduction of Gas Turbine Fuel Consumption on Gas Pipelines" ASME paper 76-GT-80 1976.

5. Heard, T.C., "Review of a Combined Steam and Gas Turbine Cycle tor Pipeline Service," ASME paper 75-GT-154 1975.

6. Wardell, R.M., and E. E. Doorly, "Current Prospects for Efficient Combined Cycles for small Gas Turbines" Solar Divsion, International Harvester, ASME Gas Turbine Conference, March 21-25, 1976 .

7. Morgan, D.T., and J. P. David, "High Efficiency Decentralized Electrical Power Utilizing Diesel Engines Coupled with Organic Working Fluid Rankine Cycle Engines Operating on Exhaust Heat," Thermo Electro Report TE 4186-27-75 to National science Foundation. 1074 .

8. Banks, W. F., "An Economic Model of Pipeline Transportation systems", System, Science, and Softwasre Report, SSS-R-77-3021. y. Banks, W.F. " $S^{3}$ Financial Projection Model - Preliminary User's Manual and system Overview", System, Science, and Software Report, SSS-R-77-3069.

10. Salluons, H., and E. Chatterton, "Napier Nomand Aircraft Diesel Engine," SAE Transactions, 63, 107-125 1955.

11. Hope, J., and R. Johnison, "A New Concept tor Reduced Fuel Consumption in Internal Combustion Engines", SAE paper 719051 1971 .

12. Anderson, K.P. and J.C. DeHaren, "The Longrun Marginal Costs of Energy Rand Corp. NIIS PB-252504 1975. 
13. Anderson, R.J. Young, and L. Sheran, "Preliminary Design Analysis of an Internally Air Cooled Diesel Engine," Engine Systems, Inc. Technical Rept. No. 12176, Contract DAAE07-76-C-0125, U.S. Army Tank - Automotive Command, 1976.

14. Kamo, R., "Ceramics for Diesel Engine" January 1976. 15. Patel, P.S. and E.F. Doyle, "Compounding the Truck Diesel Engine with an Organic Rankine Cycle System" SAF paper 760343, 1976 .

16. Baker, M.L., "Balancing the Thermal Elements," Actual Specifying Engineer, August 1962.

17. Hein, R. A., "Superconductivity Large Scale Applications" Science, 19 July 1974, 185 No. 4147.

18. DOE "National Benefits Associated with Commercial Application of Fuel Cell Power Plants," prepared by DOE by United Technologies Corp., Power Systems Div., under Purchase Order WA-76-3405, Feb. $27,1976$.

19. Aronson, Robert B.; "Fuel Cells - A Sleeper in the Energy Race" Machine Design, February 24, 1977.

20. NASA, "Background Information on Fuel Cells" Report prepared for ERDA, July 1975 .

21. Pickett, Arnold D., "Structure of the EPRI Fuel Cell Program," Program and Abstracts, ERDA/EPRI Fuel Cell Seminar June 29-30 and July, Palo Atlo, CA. 1976.

22. Handley, L.M., "The Target and FCG-1 Programs," Programs and Abstract,s, ERDA/EPRI Fuel Cell Seminar, June 29-30 and July 1, Palo Alto, CA.

23. Warshay, Marvin, "Energy Conversion Alternative Study Fuel Cell Results" Programs and Abstracts ERDA/EPRI Fuel Cell Seminar, June 29-30 July 1, Palo Alto, CA. 24. Banks, W.F., "Slurry Pipeline - Economic and Political Issues - A Review Systems Science and Sof'tware Report, SSS-R-77-3023 25. Montfort, J. G., "Operation of the Black Mesa Pipeline System," september $23,19 \% \mathrm{~b}$. 
26. Montfort, J.G., Private Communication, February 10, 1977 27. Keller, L.J., U.S. Patent 3968999, 1976.

28. Bodle, W.W., and K.C. Vyas, "Coal and Oil-Shale Conversion Looks Better," Oil and Gas Journal March 24, pp. 45-54 1975. 29. Burke, D.P., "Methanol" Chemical Week Sept. 24, pp 33-42. 30. Baumeister, Theodore, and Marks, Lionel, Mark's Standard Handbook for Mechanical Engineers, Sixth Ed. 1758 and Seventh Ed., 1967. McGraw Hill, New York, N.Y.

31. Bryson, Fredrick E., "Methanol: Old Help for a New Crisis," Machine Design, March 211974.

32. Wigg, E.E., "Methanol as a Gasoline Extender: A Critique," Science, 186,785 .

33. Farmer, R.C., "Methanol - A New Fuel Source Gas Turbine International, May - June 1976.

34. Mullany, Kervin, "Coal Conversion" Petroleum Today Sprong 1977 .

35. White, Philip C., "ERDA Fossil Energy Research Program" Environmental Science and Technology August 1976.

36. Soehngen, E., "The Development of Coal-Burning Diesel Englnes in Germany," Report FE/WAPO/3387 August, prepared for DOE under Purchase order WA76-3387.

37. Harmon, Robert A., "Operational Status and Current Trends in Gas Turbines for Utility Applications in Europe" prepared for Fossil Energy Org., ERDA Div. of Coal Conversion and Utilization Advanced Power Systems, Aug. 16, 1976.

38. Benaroya, A., Fundamentals and Application of Centrifugal

Pumps for the Practicing Engineer, Petroleum, Publishing Company, Tulsa Oklahoma, 1978.

39. Berzins, R.P. "Pumps and Pumping System Parameters," Heating/ Piping/Air Conditioning, Novembr, 1973.

40. Menon, E.S.S. "Design Procedure Can Help Select Pumps for Multiproduct Pipelines," Oil and Gas Journal, May 31, 1976. 
41. Thompson, T.L., et al., Bechtel Corp., "Slurry Pumps - A Survey" Second International Conference on the Hydraulic Transport of Solids in Pipes, Coventry, England, Sept. 1976.

42. Federal Power Commission, Statistics of Interstate Natural Gas Companies, 1974.

43. Walker, G.E., "Application of Centrifugal Compressors in the Gas Industry, Generàl Electric Co., paper GEA-2471A, Sept. 1970. 44. Robinson, S.T., "Powering of Natural Gas Pipelines Columbia Gas System Service Corp., ASME paper 72-GY-125, 1972.

45. Hale, Dean, "Foam Insulated Pipelines - A Major New Technology," Pipeline and Gas Journal, February 1973.

46. Hutson, Daryl, "New Type of Heated Pipeline Keeps Fuel Oil Flowing at Savannah Mill," Pulp and Paper, January 1976. 47. Perry, J.H. and Chilton, C.H. Chemical Engineers Handbook, 5th Ed., McGraw, H.H. New York, N.Y., 1973.

48. Kut, S. "Epoxy Coating Report From UK," E. Wood Ltd., Pipe Line Industruy, March 1967.

49. Crowe, Raymond $\mathrm{H}$., "What Transco Learned about Internal Coating of Gas Pipeline," Oil and Gas Journal, April 6, 1959. 50. Klohn, C.H., "Pipeline Flow Tests," Gas, August 1959.

51. Jacques, R.B., and W.R. Neil, "Internal Corrosion of Slurry Pipelines Causes -- Control -- Economics, paper presented at Second International Technical Conference on Slurry Transportation, Los Vega, Marnch 1977.

52. Seefeld, Carl J., Mustang Services Co., private communciation, April 1977 .

53. Virk, P.S. "Drag Reduction Fundamentals" AICHE Journal,- 21 , 46531975 .

54. Little, R.C. et al. "The Drag Reduction Phenomenon Observed Characteristics Tmproved Agents and Proposed Mechanisms," Industrial Engineering Chemistry Fund, 14, 4, 283, 195 55. Ramakrishmaro, B.B., and F. Rodriguez" Drag Reduction in Nonaqueous Liquids," AICHE Symposium Series 69,130. 
56. Brod, M., et al. "Field Experience with the Use of Additives in the Pipelines Transportation of Waxy Crudes," Journal Institute of Petroleum 57, 554, 1971.

57. Carter, C.T. "Today's Pipe Line Operation" paper presented to Oil Pipeline Educators Tour, Houston, July 21-24, 1974. 58. Interstate Commerce Commission, Annual Reports "P", Pipeline Companies, 1976. 